\title{
2. HOLES 396A AND 396B
}

\author{
Shipboard Scientific Party ${ }^{1}$
}

\section{SITE DATA, HOLE 396A}

\section{Site Summary Sheet, Hole 396A}

Date Occupied: 0120 hours, 5 February 1976

Date Departed: 2000 hours, 6 February 1976

Time on Hole: 42.7 hours

Position: $22^{\circ} 59.14^{\prime} \mathrm{N}, 43^{\circ} 30.90^{\prime} \mathrm{W}$

Water Depth (sea level): 4459 corrected meters, echo sounding

Water Depth (rig floor): 4463 corrected meters, echo sounding

Bottom Felt at: 4465 meters, drill pipe

Penetration: 123.5 meters

Number of Cores: 2

Total Length of Cored Section: 13 meters

Total Core Recovered: 0.64 meters

Percentage Core Recovery: $4.9 \%$

\section{Oldest Sediment Cored}

Depth sub-bottom: 120 meters

Nature: nannofossil foraminifer ooze

Age: Pliocene

Measured velocity: 1.5 to $1.6 \mathrm{~km} / \mathrm{sec}$

\section{Basement}

Depth sub-bottom: basement not penetrated

Nature: probably basalt (not recovered)

Velocity range: 1.5 to $1.6 \mathrm{~km} / \mathrm{sec}$

Principal Results: The purpose of drilling this hole was to determine exact sediment thickness so proper casing length could be hung below cone on deep hole attempt. This hole was washed down to near basement. Two sediment cores were taken before drilling indicated basalt was reached.

${ }^{1}$ Leonid Dmitriev (Co-chief scientist), Institute of Geochemistry, Academy of Sciences of the USSR, 47A Vorobiovscoe Shosse, Moscow W334, USSR; James Heirtzler (Co-chief scientist), Woods Hole Oceanographic Institution, Woods Hole, Massachusetts; James Kirkpatrick, Scripps Institution of Oceanography, University of California, San Diego, La Jolla, California; Drummond Matthews, Department of Geodesy and Geophysics, Cambridge University, Cambridge, England; Nikolai Petersen, Ludwig-Maximilians-Universitat Munchen Inst. f. Allg. und Angew, Geophysik, 8 Munchen 2, Theresienstr. 41/IV; Pierre Cambon, CNEXO, Boite Postale 337, 29.273 Brest Cedex, France; Jose Honnorez, Division of Marine Geology and Geophysics, Rosenstiel School of Marine and Atmospheric Science, Miami, Florida; Daniel Ohnenstetter, Laboratoire de Petrologie C.O. 140, 54.037 Nancy, Cedex, France; Hiroaki Sato, Department of Earth Sciences, Kanazawa University, Ishikawa 920, Japan; Hans Schmincke, Institut für Mineralogie, Ruhr-Universitat Bochum, D-463 Bochum, W. Germany; Henry Dick, Department of Geology and Geophysics, Woods Hole Oceanographic Institution, Woods Hole, Massachusetts; Michael Dungan, Mail Code TN6, NASA - Lyndon B. Johnson Space Center, Houston, Texas; Floyd N. Hodges, State University of New York at Stony Brook, Department of Earth and Space Sciences, Stony Brook, New York; Al Erickson, Department of Geology, University of Georgia, Athens, Georgia; Rudy Aguilar, Schlumberger Well Services, P.O. Box 7458, Long Beach, California.

\section{SITE DATA, HOLE 396B}

Date Occupied: 2000 hours, 6 February 1976

Date Departed: 1845 hours, 1 March 1976

Time on Hole: 23.9 days

Position: $22^{\circ} 59.14^{\prime} \mathrm{N}, 43^{\circ} 30.90^{\prime} \mathrm{W}$

Water Depth (sea level): 4459 corrected meters, echo sounding

Water Depth (rig floor): 4463 corrected meters, echo sounding

Bottom Felt at: 4465 meters, drill pipe

Penetration: 405.5 meters

Number of Cores: 33

Total Length of Cored Section: 270.0 meters

Total Core Recovered: 63.56 meters

Percentage Core Recovery: $23.3 \%$

Oldest Sediment Cored

Depth sub-bottom: 150.5 meters

Nature: nannofossil foraminifer ooze

Age: Middle Miocene

Measured velocity: $1.5 \mathrm{~km} / \mathrm{sec}$

Basement

Depth sub-bottom: 405.5 meters

Nature: basalt

Velocity range: 3.4 to $6.0 \mathrm{~km} / \mathrm{sec}$

Principal Results: The basalts recovered are typical mid-ocean ridge tholeiites with relatively narrow limits in chemical composition, especially for $\mathrm{MgO}$, while $\mathrm{TiO}_{2}$ and $\mathrm{FeO}^{*}$ contents are relatively high. Basalts at the top are sparsely phyric; below this, they are porphyritic and similar to ones from Hole 396. The last 90 meters is a basaltic detritus. Magnetic units from top to bottom had inclinations of $+18^{\circ}$, $-67^{\circ},-7^{\circ}$, and $+31^{\circ}$, with the last being very poorly defined. Intensities varied from 1.03 to $3.45 \times 10^{-3} \mathrm{emu} / \mathrm{cm}^{3}$. Downhole logs were run for density, sonic velocity, porosity, electrical resistivity, and natural gamma-ray activity. These logs were correlated with many of the studies of recovered samples.

\section{INTRODUCTION}

Holes 396A and 396B were drilled during Leg 46 in a sediment pond about $150 \mathrm{~km}$ east of the Mid-Atlantic Ridge at $22^{\circ} 59.14^{\prime} \mathrm{N}, 43^{\circ} 30.90^{\prime} \mathrm{W}$. Hole 396 had been drilled previously (Leg 45) to about 100 meters into basement in the sediment pond. Hole 396A was a mudline test with only 0.64 meters recovered from the two cores taken at the top of the sediment column. Hole 396B was a multiple re-entry hole which penetrated 150.5 meters of sediment and 255 meters of basaltic basement. The regional setting and the stratigraphic columns for the holes drilled on Legs 45 and 46 are presented in Initial Report, Volume 45 (Plate 1). This plate and the other results of the site survey of the area 
investigated by these two Legs are presented in the Leg 45 Initial Report (Purdy et al., 1978).

For Hole 396B the top 122 meters of sediment were washed to set the casing for the re-entry cone, and there were no cores taken in this interval. Cores 1,2 , and 3 recovered marly nannofossil ooze and foraminiferal nannofossil ooze. Core 4 had $7 \mathrm{~cm}$ of unmetamorphosed marly nannofossil ooze just above basement, which gives a date of middle Miocene (about 13 m.y., D. Bukry, personal communication). The interpretation of the magnetic data (Purdy, et al., 1978) indicates that Site 369 is located in magnetic anomaly 5 , about $9 \mathrm{~m}$.y. The nannofossil age of $13 \mathrm{~m} . \mathrm{y}$. has been used throughout this volume.

\section{Summary of Basement Drilling}

We have identified eight lithologic units in the basaltic basement in Hole 396B (Figure 1). Units 1, 2, and 3 are composed primarily of sparsely olivine and plagioclase-phyric basalt. Units 1 and 2 are pillow sequences with limestone-cemented (lithified nannofossil ooze) palagonite breccias in the upper part. Unit 1 is separated from Unit 2 by $20 \mathrm{~cm}$ of limestone. Unit 3 is a flow or sill 8.5 meters thick, although neither its top nor bottom could be identified with certainty. Unit 4 is a pillow sequence composed of porphyritic basalt with 15 to 25 per cent olivine and plagioclase phenocrysts. The average phenocryst plagioclase to olivine ratio is about $6: 1$. Unit 5 is composed of sparsely olivine and plagioclase-phyric basalt pillows and carbonate-cemented breccia. Recovery in this unit was poor, and the bottom of the unit was chosen on the basis of downhole logs. Unit 6 also has poor recovery but appears to be primarily basaltic sand, gravel, and sparsely phyric basalt pillows. Unit 7 is a moderately olivine and plagioclase phyric basalt pillow sequence, again with poor recovery. Unit 8 is basaltic gravel or sand.

Magnetic Unit I has a mean inclination of $+18^{\circ}$, but the sediment in Section 396B-13-2 has a significantly different inclination of $-35^{\circ}$. Unit II has a mean inclination of $-67^{\circ}$, excluding one sample in Section 396B-13-3 which has an inclination of $+55^{\circ}$. That exception is probably the result of misorientation. Unit III has a mean inclination of $-7^{\circ}$ with very little scatter around this value. Unit IV has a mean inclination of $+31^{\circ}$, but is poorly defined since there were few oriented samples available for magnetic study. Mean values for intensity of remanent magnetization for Units I through IV are, respectively, $1.03 \times 10^{-3}, 2.37 \times 10^{-3}$, $3.45 \times 10^{-3}$, and $1.85 \times 10^{-3} \mathrm{emu} / \mathrm{cm}^{3}$. Contrary to the findings at other sites, there was no evidence of drilling remanence during A.C. demagnetization.

Analysis of 41 basaltic samples for eight major ( $\mathrm{Si}, \mathrm{Al}$, $\mathrm{Mg}, \mathrm{Fe}, \mathrm{K}, \mathrm{Ti}, \mathrm{Ca}, \mathrm{Mn})$ and four trace $(\mathrm{Cr}, \mathrm{Ni}, \mathrm{Sr}, \mathrm{Zr})$ elements was conducted on board with $\mathrm{X}$-ray fluorescence methods. $\mathrm{H}_{2} \mathrm{O}^{+}$and $\mathrm{CO}_{2}$ analyses were made with a $\mathrm{CHN}$ analyzer. $\mathrm{Na}_{2} \mathrm{O}$ and $\mathrm{P}_{2} \mathrm{O}_{5}$ were analyzed at $\mathrm{CNEXO}$ by A.A. methods. In most cases, the freshest possible samples were chosen for analysis.

There are four major chemical units (A, B, C, D), with A subdivided into three subunits and B subdivided into two subunits (Figure 1). These major chemical units are very similar to the major lithologic units. The total chemical variation within the basalts sampled is relatively small and typical of mid-ocean ridge basalts: $\mathrm{MgO}=7$ to $9 \%$,
$\mathrm{Mg} /(\mathrm{Mg}+\mathrm{Fe})=0.57$ to $0.66 \%, \mathrm{TiO}_{2}=0.9$ to $1.7 \%, \mathrm{CaO}$ $=10.8$ to $12.8 \%, \mathrm{Al}_{2} \mathrm{O}_{3}=15$ to $18 \%$, total $\mathrm{Fe}$ as $\mathrm{FeO}=$ 7.4 to $10.4 \%, \mathrm{~K}_{2} \mathrm{O}=0.1$ to $0.35 \%, \mathrm{Zr}=60$ to $130 \mathrm{ppm}, \mathrm{Sr}$ $=110$ to $170 \mathrm{ppm}, \mathrm{Cr}=250$ to $370 \mathrm{ppm}$, and $\mathrm{Ni}=110$ to $160 \mathrm{ppm}$. The step-like chemical changes between units and the relative chemical homogeneity that exists within many of the groups may indicate that the chemically defined units represent discrete magma batches.

The basaltic rocks from Hole 396B are mostly slightly weathered to almost fresh. Six zones of more severe alteration occur near interlayers of nannofossil oozes, cemented pillow-rind breccias, and/or filled open fractures and voids in the basalt. Four of these zones coincide with the upper part of four lithological units, including the uppermost basalts of the basement just under the pond sediments.

The alteration is accompanied by fissure and vesicle fillings of secondary minerals such as calcite, zeolites, smectites, and Mn oxides/hydroxides. Strontium, "'loss on ignition,', and (to a lesser degree) $\mathrm{K}_{2} \mathrm{O}$ increase significantly during alteration. A correlation also seems to exist between the presence of smectites in slightly weathered samples and their $\mathrm{K}_{2} \mathrm{O}$ content, and between $\mathrm{CO}_{2}$ content and the observed presence of calcite.

A satisfactory correlation was noticed between the zones of maximum alteration and the porosity, density, and sound velocity logs.

The well-known relationships among wet bulk density, porosity, and velocity were found. It was somewhat of a surprise that the grain densities could be put into three groups $\left(\mathrm{d}_{1}, \mathrm{~d}_{2}, \mathrm{~d}_{3}\right)$ that have densities greater than 2.86, 2.81 , and $2.87 \mathrm{~g} / \mathrm{cm}^{3}$, respectively.

A unique aspect of the Leg 46 program was the ability to make continuous logs of density, porosity, sonic velocity, natural gamma-ray activity, and electrical resistivity. This facility was provided by Schlumberger Well Services of Long Beach, California. Other special equipment included an a.c. washer and spinner magnetometer provided by Dalhousie University, and an X-ray fluorescence unit provided by CNEXO. All this equipment greatly enhanced shipboard analysis.

The four downhole logs that were made required a total of 34 hours of ship's time. The logs were extremely valuable, especially in correlating the properties of recovered samples. For example, the unique zone of coarse basaltic sand which was found below about 310 meters sub-basement was identified in the logs. This is the first time that such logs have been made in oceanic basement, and similar logs should prove useful in future hardrock drill holes.

Comparison with dredge hauls from $22^{\circ} \mathrm{N}$ and with analyses of glasses from the FAMOUS area indicates that the Leg 46 samples are generally similar and are systematically more "evolved" than the more primitive samples from the FAMOUS area. This regional pattern, if not a result of sampling bias, may have important implications for the development of this portion of the oceanic crust. If real, this pattern may indicate tectonic conditions that restrict or slow the rise of magma beneath the ridge and, thus, prevent relatively unfractionated magmas from reaching the near sea-bottom environment. More fundamentally, it may indicate conditions of primary 


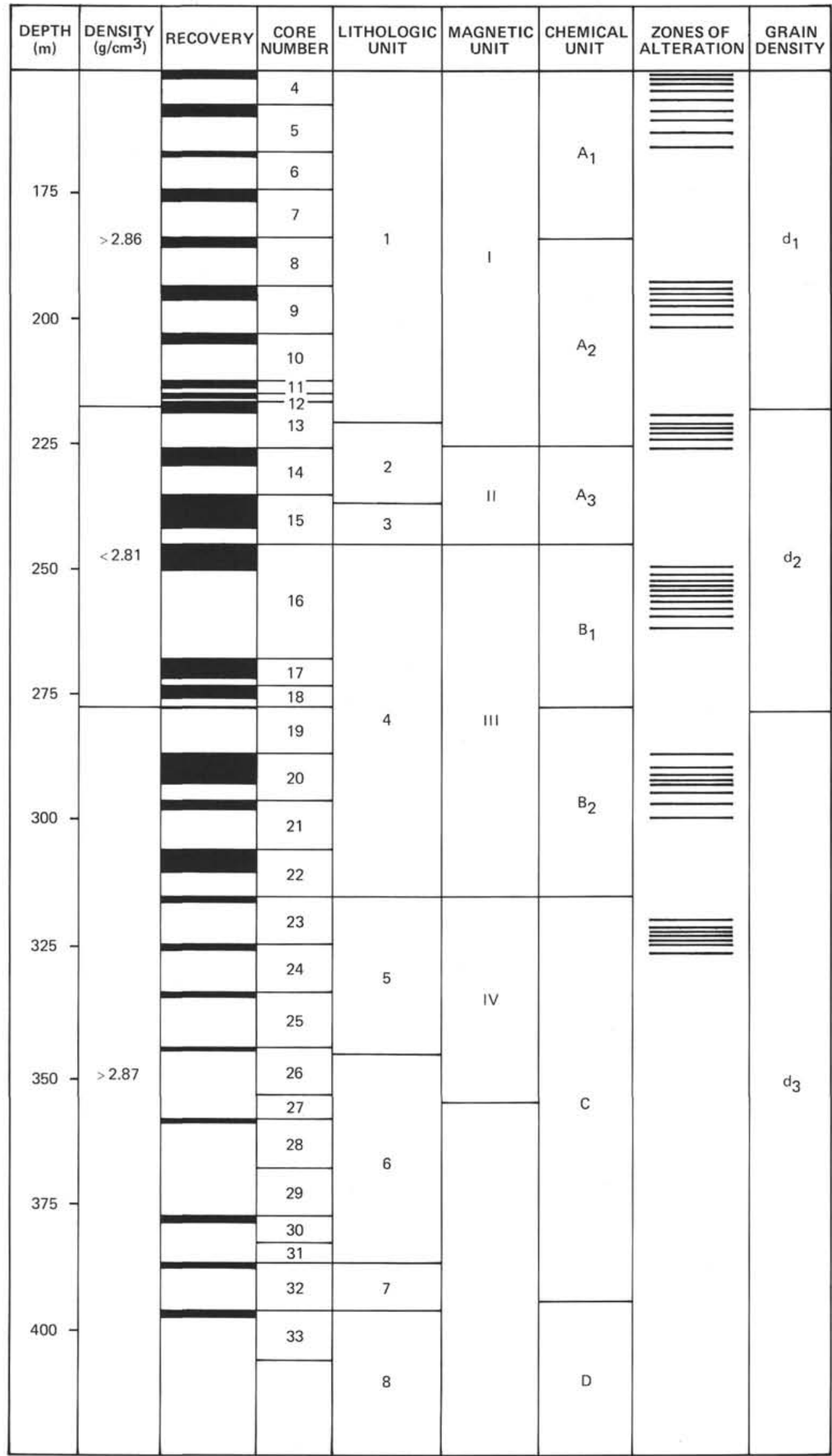

Figure 1. Stratigraphic summary of basement, Hole 396B. 
magma formation reflecting upper mantle heterogeneities and, possibly, different degrees of partial melting.

The tectonic history of the region is still largely unknown in spite of many successful physical property and downhole measurements.

\section{OPERATIONS}

\section{Hole 396A}

Since the purpose of Hole 396A was to determine the thickness of the sediments for the re-entry hole, all operations are discussed under Hole 396B Operations.

\section{Hole 396B}

On Leg 45, a one-bit hole had been drilled at Site 396; Leg 46 scientists decided to attempt a deep multiple re-entry hole nearby. The onboard records from Leg 45 indicated that no surveys of the sediment pond were made before the drilling operation. It was felt that more surveying was desirable before final decision by Leg 46 personnel on a deep hole location.

At 1540 hours local time (1840 GMT) on Wednesday, 4 February 1976, the Glomar Challenger (carrying seismic profiling gear and magnetometer streaming) arrived at a point about one mile north of the sediment pond. We turned her south and attempted to pass over the place where the 13.5-kHz beacon was believed to have been dropped on Leg 45. The Leg 45 shipboard party accurately determined the coordinates of Hole 396 by satellite navigation and they dropped a fresh beacon when departing the site, but they apparently neglected to note where the fresh beacon was with respect to their drill site.

A suitable location was passed over at 2000 GMT and the ship reversed course to drop a beacon. Since the center of the seismic profiling array is about 200 meters behind the ship, the beacon must be dropped before the repeat section is seen on the profiler. A $16-\mathrm{kHz}$ beacon was dropped at 2145 hours while we steered a westerly course. In turning and approaching this beacon on an easterly course, it appears that this beacon had landed in rocks on the rugged western edge of the pond. We decided not to use this beacon because its location might prohibit sonic reception and affect position-keeping.

We made a west-to-east pass over the $13.5-\mathrm{kHz}$ beacon and decided to drill just to the east of it. Gear was retrieved and the ship positioned 1000 feet from and $076^{\circ}$ relative to the beacon. Figure 2 shows satellite positions for Holes 396A and 396B, taken subsequently, and satellite positions that had been obtained on Leg 45 for Site 396.

At 0120 hours on 5 February, we had positioned the ship and began to lower the Hole $396 \mathrm{~A}$ pipe for testing the thickness of the sediment. There were two cores taken near the sediment-basalt interface: the first at 2040 hours and the second at 1945 hours the next day, 6 February. Over the night of 5-6 February, heat flow measurements were made in the sediments, the last being very near the basalt.

Starting about 2000 hours on 6 February, the re-entry cone was readied and keel-hauled (Figure 3 ).

Figure 4 shows a graph of penetration versus time with annotations showing various operations. During the next 23 days, six re-entries were made and numerous logistical and technical problems were encountered. Some of the problems were:

1) Upon re-entry, difficulty in getting drill pipe over the cone after locating it.

2) Computer failure on three occasions, once for 12 hours.

3) Cement backed into drill hole and had to be drilled out.

4) Ring for casing release jammed just below the moon pool, requiring diver observation and construction of recovery hook.

5) Heave compensator did not work, and its hydraulic system lost oil (insufficient replacement on board).

6) Free fall of heat flow probe produced bent probe and no data.

7) Roll of ship (up to $9^{\circ}$ ) necessitated retrieving the pipe string and waiting for better weather; no coring for 48 hours.

8) Replacement of broken shaft to Bowen sub, repair job that took 9 hours.

9) Break of support for rail of major block for pulling pipe and damage to derrick, forcing termination of cruise 11 days early (the cruise started 3 days late due to repairs of thrusters in San Juan).

In spite of these difficulties, 33 cores (see Coring Summary, Table 1) were taken to a maximum depth of 405.5 meters below the sea floor. The drilling rate is given in Table 2 and shown graphically in Figure 5. Slower rates of drilling yielded a general increase in per cent recovery and frequently made it possible to piece massive basalt pieces together. Higher rates produced drilling breccia and low recovery. Starting about Core 396B-23, basaltic sand and gravel (fine breccia) were encountered. A sock placed in the core catcher recovered nearly a meter of basaltic sand in Core 396B-32 and in Core 396B-33.

Core 396B-16 was taken from a 23-meter drilled section, although the accompanying tables show a separate cored and drilled section. The 5.8 meters recovered could have come from anywhere in the 23-meter drilled section. We would have cut more of these long sections but we encountered sand and wanted to sample frequently. Cutting long sections would have speeded up the drilling rate, just as it did on Leg 37.

Core 396B-19 contained sand-size material, apparently the result of reaming the hole upon re-entry. This core also contained large Globigerina microfossils, indicative of surface sediments having been washed into the hole.

At 1700 hours on 26 February, we decided that further drilling was impossible because of poor conditions, i.e., the drill bit had been stuck for about an hour. The following downhole experiments were then undertaken: a logging program, a test of the wall-lock geophone in the pipe, and a hydrophone in the hole.

It is worth comparing the success of deep drilling on Leg 37 (Hole 332B), Leg 45 (Hole 395A), and Leg 46 (Hole 396B). Figure 6 shows sub-bottom penetration versus on-site days. Figure 7 is the same except all the non-drilling time is illustrated by the flat parts of the curve and the rate of penetration by the falling part of the curve. These graphs show clearly that the extra work required to set a maxicone and the additional repair time can defeat any advantage gained by utilizing a stronger cone. 


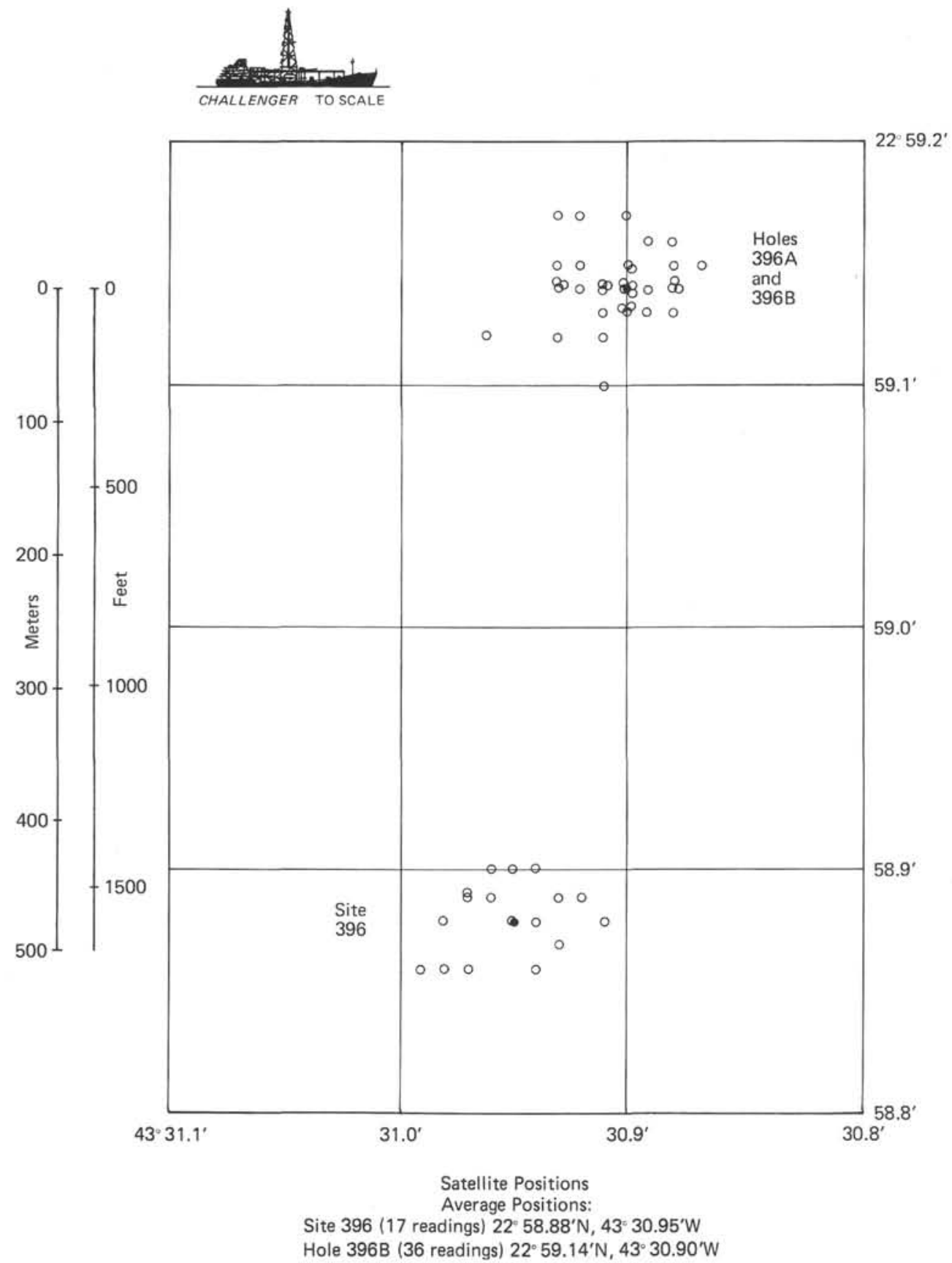

Figure 2. Satellite navigation positions, Holes 396 (Leg 45), 396A, and 396B.

\section{SEDIMENTS}

\section{Lithology and Biostratigraphy}

The sediments obtained at Site 396 are nannofossil ooze, nannofossil-foraminifer ooze, and marly nannofossil ooze. Sediments were recovered from 0 to 19 meters sub-bottom in Hole 396A and from the mudline test. After washing the first 122 meters to set casing, coring in Hole $396 \mathrm{~B}$ was continuous from 122 to 151 meters sub-bottom with total recovery of 5.2 meters $(18 \%)$. A complete sedimentary sequence near this site was obtained at Hole 396 (Leg 45).

The lowest sediment in Hole 396B is middle Miocene, about 13 m.y.B.P. from the Coccolithus miopelagicus Subzone of the Discoaster exilis Zone (Bukry, in press).
The sediments in Hole 396A are totally unconsolidated grayish orange nannofossil-foraminifer ooze with about 15 per cent clay.

The sediments in Hole 396B can be divided into two lithological units. Unit 1 (Cores 1 and 2, 122.0 to $138.2 \mathrm{~m}$ sub-bottom) corresponds to Unit 1 of Hole 396, and consists of grayish orange nannofossil ooze with a $4-\mathrm{cm}$ bed of nannofossil-foraminifer ooze at the base. Foraminifers are present in small numbers throughout the unit; sponge spicules are rare; terrigenous and volcanogenic components are notably absent. Deformation due to drilling is intense.

Unit 2 (Sections 2-1 to $4-1,138.2$ to 151 m sub-bottom) corresponds to Unit 2 of Hole 296 and consists of brownish yellow to dark brown marly nannofossil ooze. Foraminifers 


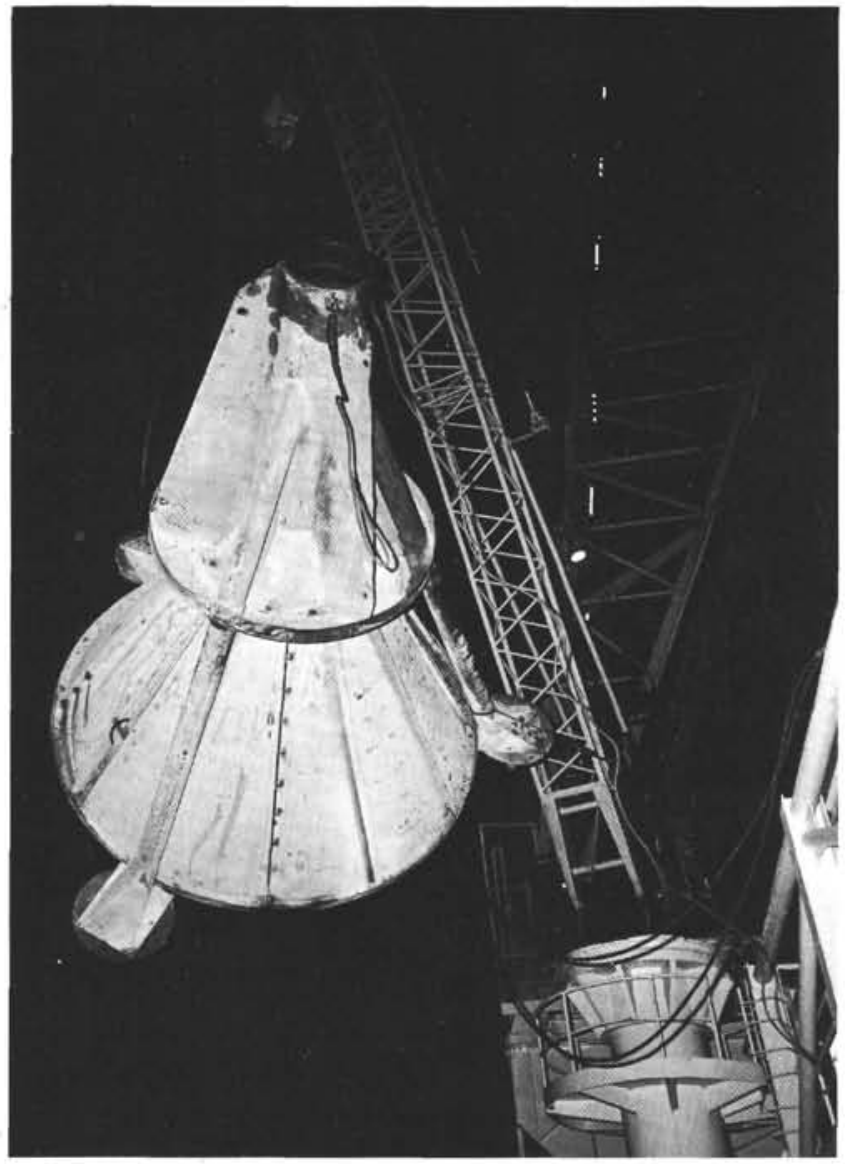

Figure 3. Re-entry cone going over the side of the ship.

are rare. Drilling deformation is intense. The sediment-basalt contact is not preserved, but the sediment nearest the basalt is unmetamorphosed, and there is no reason to believe that the contact is not sedimentary.

Bits of sediment were also obtained interbedded with basalt. Notable pieces occur in the top of the sparsely phyric unit (e.g., Sections 5-2 and 6-1) and are mixed with palagonite to form the breccia in the top of the sparsely phyric unit. The interbedded sediment is well lithified nannofossil ooze with rare preserved foraminifer outlines. Nannofossils are not preserved.

\section{Physical Properties and Chemistry}

Because of the short sections and the complete data obtained at Hole 396, no routine physical property or chemical data were obtained for the sediments from 396B. Thermal conductivity data will be discussed under heat flow.

\section{IGNEOUS ROCKS}

\section{Lithology, Petrography, and Mineralogy}

Lithology summary: We have divided the basaltic rocks of Site $396 \mathrm{~B}$ into eight lithologic units. Figure 8 is a stratigraphic column showing these units and their lithologies. Unit $1(150.5$ to $222.0 \mathrm{~m})$, Unit $2(222.0$ to $235.0 \mathrm{~m})$, and Unit $3(235$ to $244.0 \mathrm{~m})$ are composed primarily of sparsely olivine and plagioclase phyric basalt. Units 1 and 2 are pillow sequences which contain some lithified nannofossil ooze. Unit 1 has limestone-cemented palagonite breccia in its upper part, and is separated from Unit 2 by $20 \mathrm{~cm}$ of limestone. Unit 3 is a flow or sill about 8.5 meters thick; neither its top nor bottom can be identified with certainty. Unit $4(244.0$ to $315.0 \mathrm{~m})$ is a pillow sequence composed of porphyritic basalt with 15 to 25 per cent olivine and plagioclase phenocrysts. The average plagioclase to olivine ratio is about $6 / 1$. Unit 5 (315.0 to $340.0 \mathrm{~m}$ ) is composed of sparsely olivine and plagioclase phyric basalt pillows and carbonate-cemented palagonite breccia. Recovery of this unit was poof, and the bottom has been chosen on the basis of changes in the downhole logs (see section on logging). Unit 6 (340.0 to $386.5 \mathrm{~m}$ ) also has poor recovery, but appears to be primarily basaltic sand and fine gravel, and sparsely phyric basalt pillows. The logging results do not aid in determining the bottom of this unit. Unit 7 (386.5 to $396.0 \mathrm{~m})$ is a moderately olivine and plagioclase phyric basalt pillow sequence, again with poor recovery. Unit 8 (396.0 to $405.5 \mathrm{~m})$ is a basaltic sand and fine gravel.

\section{Comparison of Holes 396 and 396B}

Hole 396, Leg 45, is located about 500 meters south-southwest of Hole 396B. Hole 396 penetrated a pillow sequence composed of olivine and plagioclase phyric basalts, with many glass zones and lithified sediment veins; this sequence is lithologically similar to the phyric basalt sequence (Unit 3) at Hole 396B. Petrographically and chemically, however, it is slightly different (see section on chemistry). The Hole 396B phyric basalts average 20 per cent $( \pm 5 \%)$ phenocrysts, while the upper unit of Hole 396 averages 5 to 10 per cent phenocrysts and the lower unit averages 15 per cent (see Tables 3 and 4). In addition, spinel microphenocrysts are much more common at Hole $396 \mathrm{~B}$ ( 8 of 12 thin sections) than at Hole 396 ( 1 of 8 thin sections). The olivine/plagioclase ratio is about the same in both holes.

\section{Upper Sparsely Phyric Sequence}

Lithologic Units 1,2 , and 3 (the upper sparsely phyric sequence) consist of a sparsely to very sparsely olivine and plagioclase phyric basalt pillow sequence with interbedded carbonate sediment and a thick cooling unit (a flow or shallow sill) at the base. The contact of the basalt with the overlying sediment (Section 396B-4-1) appears sedimentary, since the overlying marly nannofossil ooze is not baked. This sequence extends from 151 to 244 meters subbottom (Cores 4 through 15$)$. Unit 1 (151 to $222 \mathrm{~m}$ ) is separated from Unit 2 (222 to $235 \mathrm{~m}$ ) by $20 \mathrm{~cm}$ of lithified nannofossil ooze. Unit 1 contains numerous fragments of limestone-cemented palagonite breccia, in its upper part. Unit 3 (235 to $244 \mathrm{~m}$ ) is a single cooling unit (flow or shallow sill).

Recovery averaged 31 per cent throughout the sequence, and 69 per cent in the thick cooling unit.

\section{Pillow and Breccia Sequence}

Units 1 and 2 consist of basalt and lithified carbonate sediment, apparently nannofossil ooze. Pieces of pillow rinds are common throughout the sequence. Since complete pillows were not recovered, it is not possible to determine 


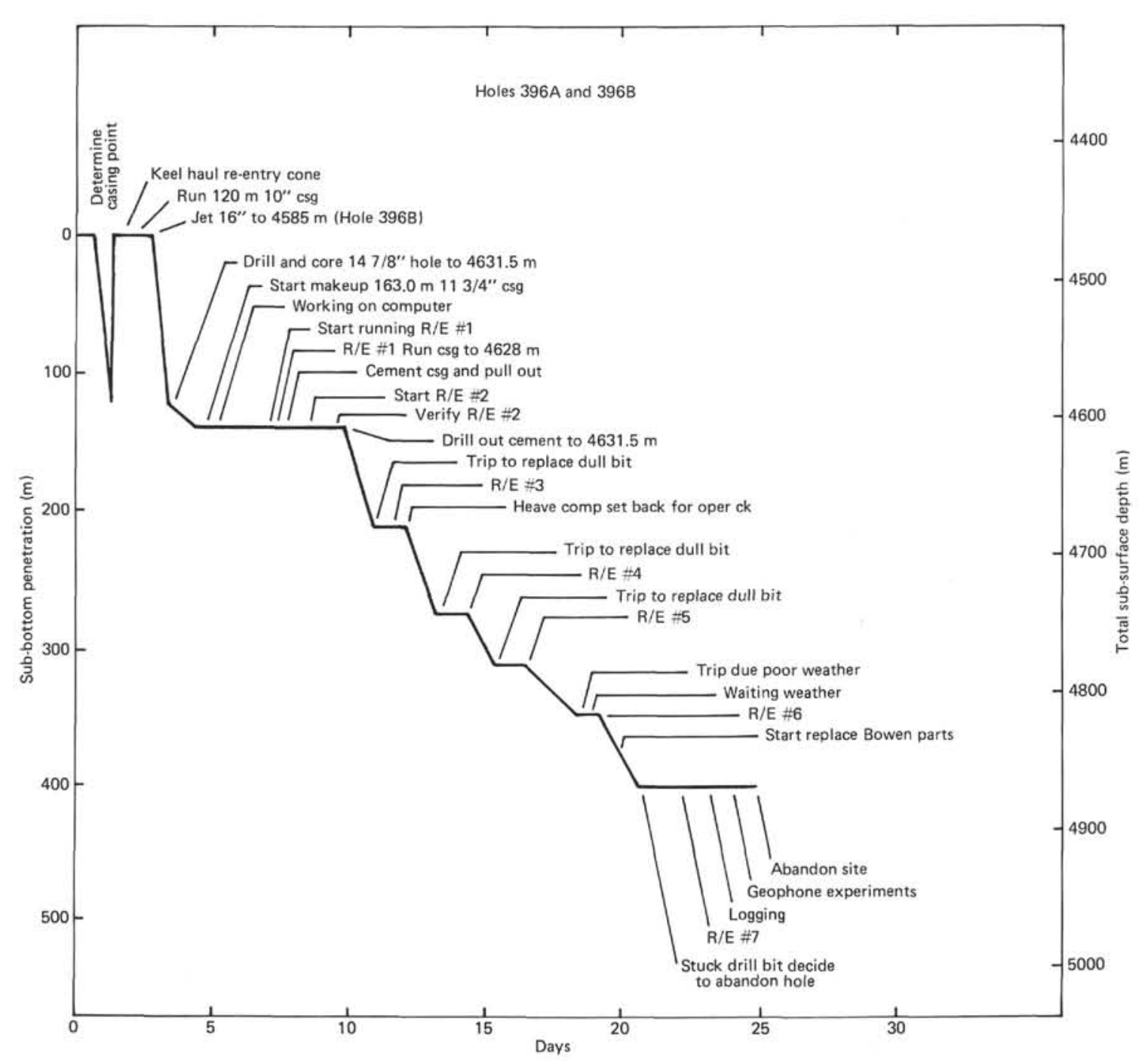

Figure 4. Annotated drilling record for Hole 396B.

the average pillow size. The largest pillow fragment observed is about $40 \mathrm{~cm}$ (Section 396B-14-1). Carbonate-cemented palagonite breccia is abundant in the upper part of Unit 1 (Cores 4 through 6), and palagonitized pillow rinds occur throughout. Figures 9 and 10 show typical pieces of palagonite breccia. The breccia consists of pieces of palagonitized basaltic glass, one-half to several centimeters across, cemented together by lithified carbonate sediment (probably nannofossil ooze). A few foraminifer outlines and pellitoids can be seen, but fossils are not generally apparent. In many cases, breccia is attached to a glassy pillow rind.

Macroscopically, the basalt is fine grained, generally with a microlitic texture. The pillow margins are glassy (sometimes palagonitized). Next to the margin is a variolitic zone usually 0.5 to $1.0 \mathrm{~cm}$ thick, containing a spherulitic zone and microlitic interior. Groundmass pyroxene is distinguishable in some of the coarser samples. Phenocrysts of olivine and plagioclase make up 1 per cent or less of the rock, and appear to be about equally abundant. The olivine phenocrysts are euhedral to rounded and average about 0.5 $\mathrm{cm}$ in diameter. Most are altered to iddingsite. The plagioclase phenocrysts are euhedral to anhedral, and contain abundant dark inclusions. They average 2 to $3 \mathrm{~mm}$ in diameter and may reach up to $1 \mathrm{~cm}$; the latter may be glomerocrysts.

Thin sections confirm the macroscopic observations. The number of olivine phenocrysts exceeds the number of plagioclase phenocrysts, but together they constitute 1 per cent or less of the rock. The groundmass texture is microlitic interstitial except near pillow margins; the margins are glass. The glass grades into a variolitic zone, which grades into a zone with bow-tie spherulites, and then into the microlitic interior. Figure 11 illustrates a typical thin section of a microlitic interior.

The olivine phenocrysts are euhedral to anhedral, and vary from 0.3 to $2.0 \mathrm{~mm}$. Most are altered to iddingsite. Microprobe analyses (Flower et al.; Kirkpatrick; Sato et al., this volume) indicate compositions in the range Fo84 to Fo86. One thin section (Section 396B-5-2) contains a rounded olivine phenocryst with a kink band.

The plagioclase phenocrysts are both euhedral and rounded, and range from 0.5 to $3.5 \mathrm{~mm}$, although the larger ones (of glass and divitrified glass) can be seen in hand specimen. Microprobe analyses give compositions in the range $\mathrm{An}_{69}$ to $\mathrm{An}_{80}$. 
TABLE 1

Coring Summary for Holes 396A and 396B

\begin{tabular}{|c|c|c|c|c|c|c|c|}
\hline Core & $\begin{array}{c}\text { Date } \\
\text { (Feb. 1976) }\end{array}$ & $\begin{array}{l}\text { Time } \\
(\mathrm{hr})\end{array}$ & $\begin{array}{l}\text { Depth From } \\
\text { Drill Floor } \\
(\mathrm{m})\end{array}$ & $\begin{array}{l}\text { Depth Below } \\
\text { Sea Floor } \\
(\mathrm{m})\end{array}$ & $\begin{array}{l}\text { Cored } \\
(\mathrm{m})\end{array}$ & $\begin{array}{l}\text { Recovered } \\
\text { (m) }\end{array}$ & $\begin{array}{c}\text { Recovery } \\
(\%)\end{array}$ \\
\hline \multicolumn{8}{|c|}{ Hole 396A } \\
\hline 1 & 5 & 2040 & $4468.0-4477.5$ & $0.0-9.5$ & 9.5 & 0.6 & 6.3 \\
\hline 2 & 6 & 1945 & $4477.5-4487.0$ & $9.5-19.0$ & 9.5 & $\mathrm{CC}$ & 1.0 \\
\hline \multicolumn{8}{|c|}{ Hole 396B } \\
\hline 1 & 9 & 1338 & $4587.0-4596.5$ & $122.0-131.5$ & 9.5 & 1.95 & 20.5 \\
\hline 2 & 9 & 1524 & $4596.5-4606.0$ & $131.5-141.0$ & 9.5 & 1.50 & 15.8 \\
\hline 3 & 9 & 1736 & $4606.0-4615.5$ & $141.0-150.5$ & 9.5 & 1.70 & 17.9 \\
\hline 4 & 10 & 0055 & $4615.5-4622.0$ & $150.5-157.0$ & 6.5 & 1.46 & 22.0 \\
\hline 5 & 10 & 0645 & $4622.0-4631.5$ & $157.0-166.5$ & 9.5 & 2.23 & 23.0 \\
\hline 6 & 15 & 2335 & $4631.5-4639.0$ & $166.5-174.0$ & 7.5 & 0.85 & 11.0 \\
\hline 7 & 16 & 0345 & $4639.0-4648.5$ & $174.0-183.5$ & 9.5 & 2.4 & 25.0 \\
\hline 8 & 16 & 0755 & $4648.5-4658.0$ & $183.5-193.0$ & 9.5 & 1.87 & 20.0 \\
\hline 9 & 16 & 1120 & $4658.0-4667.5$ & $193.0-202.5$ & 9.5 & 3.0 & 32.0 \\
\hline 10 & 16 & 1450 & $4667.5-4677.0$ & $202.5-212.0$ & 9.5 & 2.0 & 22.0 \\
\hline 11 & 16 & 1850 & $4677.0-4679.5$ & $212.0-214.5$ & 2.5 & 1.7 & 68.0 \\
\hline 12 & 17 & 0435 & $4679.0-4680.5$ & $214.5-216.0$ & 1.5 & 1.12 & 67.0 \\
\hline 13 & 18 & 0600 & $4681.0-4690.5$ & $216.0-225.5$ & 9.5 & 2.25 & 24.0 \\
\hline 14 & 18 & 0915 & $4690.5-4700.0$ & $225.5-235.0$ & 9.5 & 3.35 & 35.0 \\
\hline 15 & 18 & 1345 & $4700.0-4709.5$ & $235.0-244.5$ & 9.5 & 6.6 & 69.0 \\
\hline 16 & 18 & 2205 & $4709.5-4719.0$ & $244.5-254.0$ & 9.5 & 5.8 & 61.0 \\
\hline Drilled & 18 & & $4719.0-4732.5$ & $254.0-267.5$ & 13.5 & - & - \\
\hline 17 & 19 & 0220 & $4732.5-4738.0$ & $267.5-273.0$ & 5.5 & 4.25 & 77.0 \\
\hline 18 & 19 & 0515 & $4738.0-4742.0$ & $273.0-277.0$ & 4.0 & 2.3 & 58.0 \\
\hline 19 & 20 & 1555 & $4742.0-4751.5$ & $277.0-286.5$ & 9.5 & 0.07 & 1.0 \\
\hline 20 & 20 & 2100 & $4751.5-4761.0$ & $286.5-296.0$ & 9.5 & 6.6 & 69.0 \\
\hline 21 & 21 & 0545 & $4761.0-4770.5$ & $296.0-305.5$ & 9.5 & 1.45 & 15.0 \\
\hline 22 & 21 & 1040 & $4770.5-4780.0$ & $305.5-315.0$ & 9.5 & 4.5 & 47.0 \\
\hline 23 & 23 & 0005 & $4780.0-4789.5$ & $315.0-324.5$ & 9.5 & 0.95 & 10.0 \\
\hline 24 & 23 & 0245 & $4789.5-4799.0$ & $324.5-334.0$ & 9.5 & 0.70 & 7.3 \\
\hline 25 & 23 & 0510 & $4799.0-4808.5$ & $334.0-343.5$ & 9.5 & 0.12 & 0.1 \\
\hline 26 & 23 & 1810 & $4808.5-4818.0$ & $343.5-353.0$ & 9.5 & 0.07 & 0.7 \\
\hline 27 & 25 & 0920 & $4818.0-4823.0$ & $353.0-358.0$ & 5.0 & 0.0 & 0.0 \\
\hline 28 & 25 & 1315 & $4823.0-4832.5$ & $358.0-367.5$ & 9.5 & 0.08 & 0.7 \\
\hline 29 & 25 & 1700 & $4832.5-4842.0$ & $367.5-377.0$ & 9.5 & 0.0 & 0.0 \\
\hline 30 & 25 & 2140 & $4842.0-4847.0$ & $377.0-382.0$ & 5.0 & 1.0 & 20.0 \\
\hline 31 & 26 & 0230 & $4847.0-4851.5$ & $382.0-386.5$ & 4.5 & 0.0 & 0.0 \\
\hline 32 & 26 & 1210 & $4851.5-4861.0$ & $386.5-396.0$ & 9.5 & 0.82 & 9.0 \\
\hline 33 & 26 & 1555 & $4861.0-4870.5$ & $396.0-405.5$ & 9.5 & 0.90 & 9.0 \\
\hline
\end{tabular}

The groundmass minerals are olivine (1 to $4 \%$ ), plagioclase (20 to $50 \%$ ), clinopyroxene ( 0 to $30 \%$ ), and titanomagnetite ( 3 to $5 \%$ ). Groundmass olivine occurs in most thin sections of basalt (396B-5-2, \# 2 is an exception). The other groundmass phases occur in all thin sections except near pillow margins, where clinopyroxene and titanomagnetite are suppressed.

Olivine was the first groundmass phase to form. Near pillow margins, it forms dendritic and skeletal lantern-shaped crystals up to $1 \mathrm{~mm}$ long. In pillow interiors, it forms subhedral to anhedral crystals about $0.05 \mathrm{~mm}$ long.

Plagioclase appears to be the second groundmass phase to form. Near the pillow margins, it forms the center of varioles and also occurs as isolated grains. It is also the phase forming the bulk of the varioles. Further into the pillow centers, it forms bow-tie spherulites and small laths about $0.3 \mathrm{~mm}$ long. In the pillow centers, it forms microlites up to $1 \mathrm{~mm}$ long. In all cases, the microlites are skeletal, and some appear to be in radiating clusters with olivine. Microprobe analyses (Flower et al., this volume) indicate compositions in the range $\mathrm{An}_{55}$ to $\mathrm{An}_{68}$.
Clinopyroxene grows as feathery dendrites and small blocky crystals interstitial to the plagioclase in the pillow interiors. Near the pillow margins, clinopyroxene is not identifiable, although it may be in the varioles. Maximum grain size is about $0.3 \mathrm{~mm}$.

Titanomagnetite occurs as 1 to $4 \mu \mathrm{m}$ dendritic crystals interstitial to the plagioclase, except in the glassy and variolitic zones where it is not present (see section on opaque mineralogy).

Glass, altered glass, and secondary minerals are common in all basalt samples (see section on alteration). The pillow rinds are usually all glass (unaltered or palagonitized), with the percentage of glass decreasing towards the centers of the pillows where it may constitute 10 to 20 per cent. Some glass and very fine-grained devitrified glass occur as round blebs which are most likely filled or partially filled vesicles.

\section{The Cooling Unit}

Unit 3 (235 to $244 \mathrm{~m})$ is a shallow sill or flow which is lithologically similar to the overlying pillow sequence. Most of the unit was continuously recovered. 
TABLE 2

Hole 396B Drilling Data

\begin{tabular}{|c|c|c|c|c|c|}
\hline Core & $\begin{array}{l}\text { Penetration } \\
\text { (m) }\end{array}$ & $\begin{array}{c}\text { Drilling } \\
\text { Time } \\
\text { (min) }\end{array}$ & $\begin{array}{l}\text { Rate } \\
(\mathrm{m} / \mathrm{hr})\end{array}$ & $\begin{array}{l}\text { Recovery } \\
\text { (m) }\end{array}$ & $\begin{array}{c}\text { Recovery } \\
(\%)\end{array}$ \\
\hline 1 & 9.5 & 15 & 38 & 1.95 & 21 \\
\hline 2 & 9.5 & 26 & 21.9 & 1.50 & 16 \\
\hline 3 & 9.5 & 42 & 13.6 & 1.70 & 18 \\
\hline 4 & 6.5 & 215 & 1.8 & 1.46 & 22 \\
\hline 5 & 9.5 & 240 & 2.4 & 2.23 & 23 \\
\hline 6 & 7.5 & 60 & 7.5 & 0.85 & 10 \\
\hline 7 & 9.5 & 150 & 3.8 & 2.4 & 25 \\
\hline 8 & 9.5 & 160 & 3.6 & 1.87 & 20 \\
\hline 9 & 9.5 & 114 & 5.0 & 3.0 & 32 \\
\hline 10 & 9.5 & 116 & 4.9 & 2.0 & 21 \\
\hline 11 & 2.5 & 141 & 1.1 & 1.7 & 68 \\
\hline 12 & 1.5 & 90 & 1.0 & 1.1 & 75 \\
\hline 13 & 9.5 & 120 & 4.8 & 2.3 & 24 \\
\hline 14 & 9.5 & 122 & 4.7 & 3.4 & 35 \\
\hline 15 & 9.5 & 182 & 3.1 & 6.6 & 69 \\
\hline 16 & 9.5 & 131 & 4.4 & 5.8 & 61 \\
\hline No core & 13.5 & 288 & 2.8 & No core & 0 \\
\hline 17 & 5.5 & 172 & 1.9 & 4.25 & 77 \\
\hline 18 & 4.0 & 46 & 5.2 & 2.3 & 58 \\
\hline 19 & 9.5 & 184 & 3.1 & 0.07 & 1 \\
\hline 20 & 9.5 & 185 & 3.1 & 6.6 & 69 \\
\hline 21 & 9.5 & 164 & 3.5 & 1.45 & 15 \\
\hline 22 & 9.5 & 179 & 3.2 & 4.5 & 47 \\
\hline 23 & 9.5 & 83 & 6.9 & 0.95 & 10 \\
\hline 24 & 9.5 & 69 & 8.3 & 0.70 & 7 \\
\hline 25 & 9.5 & 57 & 10.0 & 0.12 & 1 \\
\hline 26 & 9.5 & 136 & 4.2 & 0.07 & 1 \\
\hline 27 & 5.0 & 29 & 10.3 & 0 & 0 \\
\hline 28 & 9.5 & 100 & 5.7 & 0.08 & 1 \\
\hline 29 & 9.5 & 99 & 5.8 & 0 & 0 \\
\hline 30 & 5.0 & 7 & 42.9 & 1.0 & 20 \\
\hline 31 & 4.5 & 12 & 22.5 & 0 & 0 \\
\hline 32 & 9.5 & 73 & 7.8 & 0.82 & 9 \\
\hline 33 & 9.5 & 146 & 3.9 & 0.90 & 9 \\
\hline
\end{tabular}

Unfortunately, the top and bottom cannot be positively identified; the third glass specimen in Section 396B-15-1 may be on top.

Macroscopically, the unit consists of very sparsely olivine and plagioclase phyric basalt with a microlitic intersertal to medium-grained intergranular texture. The margins (Sections 15-1 to 15-5) are fine grained, and there is a continuous increase in plagioclase grain size towards the center (Sections 15-3 and 15-4). Phenocrysts of olivine (up to $3 \mathrm{~mm}$ ) and plagioclase (up to $5 \mathrm{~mm}$ ) constitute less than 1 per cent of the rock, and plagioclase appears to be more abundant. Groundmass plagioclase is clearly visible in hand specimen, but the other groundmass phases are not. Much of the central part is very fresh (see section on alteration). Many of the olivine phenocrysts are iddingsitized.

The cooling unit appears more complex in thin section than in hand specimen. There is a continuous variation in grain size throughout the unit, except for Sample 15-3, \#3A. In this sample, while the intergranular texture appears quite coarse in hand specimen, thin section observation reveals the pyroxene is much finer than either above or below.

The phenocrysts are very sparse; in fact, olivine is not seen in any thin section, and plagioclase only in a few. The main groundmass phases are olivine ( 2 to $4 \%$ ), plagioclase
(50 to $60 \%$ ), clinopyroxene (30 to $40 \%$ ), and titanomagnetite plus ilmenite (about 5\%) (see section on opaque mineralogy).

Olivine occurs as anhedral, granular crystals, 0.05 to 0.2 $\mathrm{mm}$ across. Microprobe analyses (Flower et al.; Kirkpatrick; this volume) indicate compositions in the range Fo76 to Fo84. Plagioclase occurs as skeletal laths about 1 $\mathrm{mm}$ long near the margins and up to $3 \mathrm{~mm}$ long in the center. Compositions range from $\mathrm{An}_{57}$ to $\mathrm{An}_{69}$. Clinopyroxene occurs as dendritic feathers and skeletal crystals near the margins and in Sample 15-3, \#3A, and as blades and subophitic crystals in the central part of the unit. The opaque phases occur as dendritic crystals up to $50 \mu \mathrm{m}$ across.

\section{Porphyritic Unit}

Lithologic Unit 4, an olivine-plagioclase phyric basalt pillow sequence, extends from the lowest part of Core 15 $(244 \mathrm{~m})$ to Core $22(315 \mathrm{~m})$. Lithified carbonate sediment occurs between some pillows. Recovery averaged 47 per cent for the unit.

In Section 20-1, two complete sections of pillows were obtained. The arrangement and the dips of the glass zones indicate the pillows are oval-shaped and about 80 by $50 \mathrm{~cm}$. The average frequency of glass occurrence is about 2.3 pieces/meter of recovery, and the highest value is in Core 20 (3.6 pieces $/ \mathrm{m}$ of the recovered core). The pillow margins show a systematic textural variation very similar to that observed in the sparsely phyric pillow units. The rim is partly palagonitized sideromelane glass $(1.5$ to $2.0 \mathrm{~mm}$ average thickness). The pillows comprise an outer cryptocrystalline variolitic zone, a microcrystalline spherulitic zone, followed by a microlitic intersertal interior. Figure 12 shows the frequency of the thickness of each zone. Most of the cryptocrystalline variolite zone consists of coalesced varioles, while the outer portion is characterized by a thin zone of detached variolites ( 1 to 3 $\mathrm{mm}$ thick), where the interstitial glass is often palagonitized. The microcrystalline spherulite zone is distinguished from the cryptocrystalline variolite zone by an abrupt inward increase of the degree of alteration, although the crystallinity increases rather gradually. The basalt usually contains less than 2 per cent vesicles of 0.1 to 1.0 $\mathrm{mm}$, although some samples in Core 21 contain up to 5 per cent of vesicles. In one of the complete pillows in Section $20-1$, the abundance of vesicles increases gradually towards the margin of the pillow.

The phenocryst phases are plagioclase, olivine, and rare spinel. Plagioclase phenocrysts are usually 0.2 to $4 \mathrm{~mm}$ in length, but can reach $10 \mathrm{~mm}$. The larger plagioclase phenocrysts often contain glass inclusions. The olivine phenocrysts range from 0.2 to $3 \mathrm{~mm}$. Much of the olivine is partly or wholly altered to iddingsite, while the groundmass is only moderately altered. Olivine and plagioclase phenocrysts sometimes occur as glomerophyric aggregates up to $20 \mathrm{~mm}$ in diameter, e.g., Sample 396B-16-5, \#7.

Core 19 contains poorly sorted sand composed primarily of volcanic fragments, which consist of fine-grained basalt ( $80 \%, 1$ to $20 \mathrm{~mm})$; basaltic glass with palagonite and carbonate crust $(15 \%, 1$ to $10 \mathrm{~mm})$; palagonite fragments 


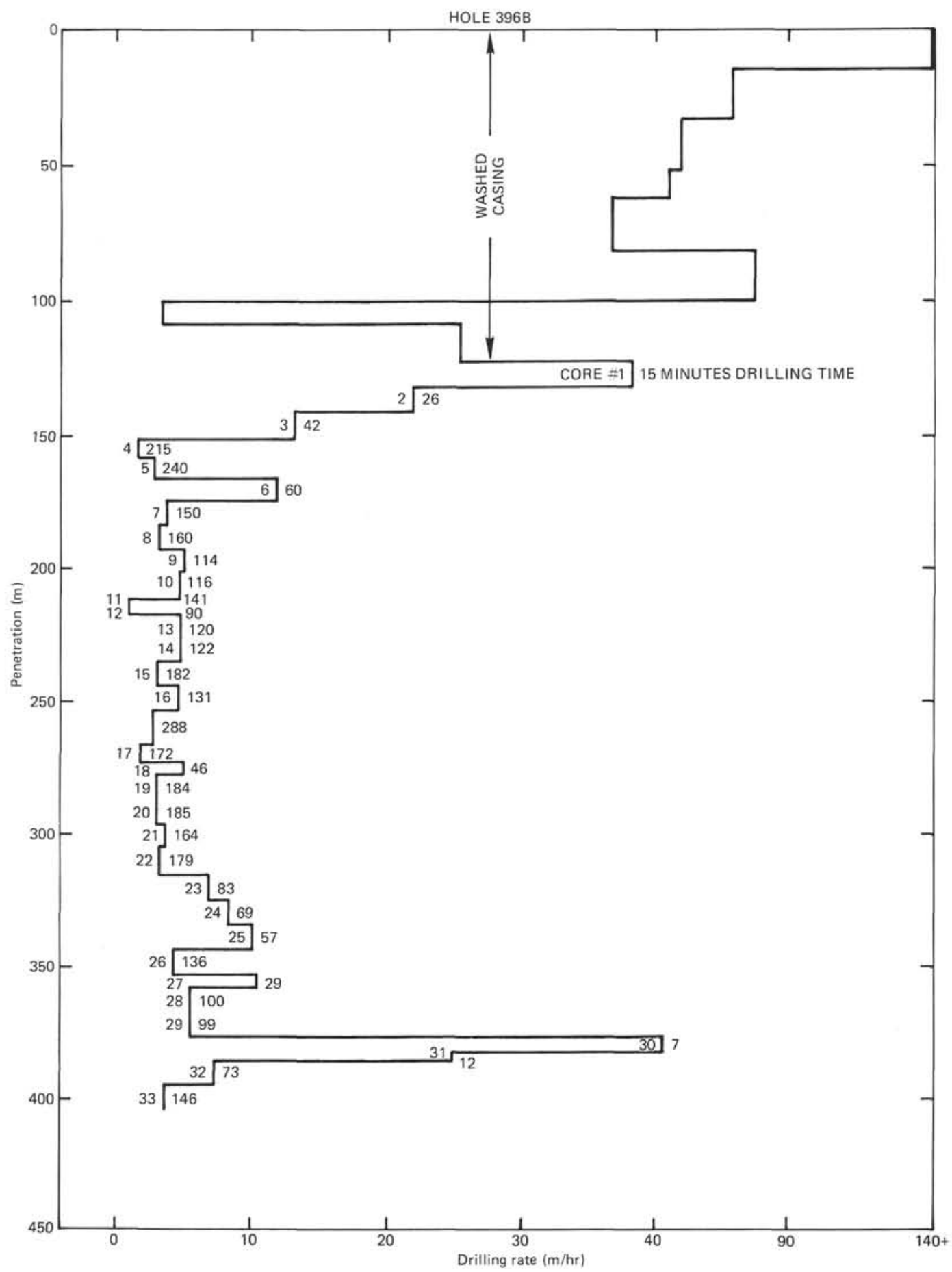

Figure 5. Drilling rates for Hole $396 B$.

with carbonate crust ( $\leqslant 1 \%, 1$ to $10 \mathrm{~mm})$; lithified carbonate ( $\leqslant 1 \%, 1$ to $10 \mathrm{~mm})$; foraminifers $(\leqslant 1 \%)$; and olivine and plagioclase crystals $(\leqslant 1 \%, 1 \mathrm{~mm})$. Lithic fragments are angular to subangular and show poor sphericity. Most of the basaltic fragments are aphyric, although a few contain fairly abundant ( 20 to $30 \%$ ) plagioclase and olivine phenocrysts. This material appears to be drilling breccia (Dick et al., this volume).

In thin section, there are 11 to 26 per cent plagioclase, olivine, and spinel phenocrysts. The plagioclase phenocrysts often have discontinuous normal zoning at the rims. Microprobe analyses (Sato et al.; Flower et al.; Kirkpatrick, this volume) indicate a range of compositions from $\mathrm{An}_{70}$ to $\mathrm{An}_{85}$. The plagioclase/olivine ratio ranges from 3 to 8 and averages about 6. Microprobe analyses indicate a range of compositions from Fos5 to Fo90. Dark brown to reddish spinel occurs as inclusions in plagioclase and olivine as well as isolated microphenocrysts, is idiomorphic to subrounded, and ranges from 0.02 to 0.6 $\mathrm{mm}$. 


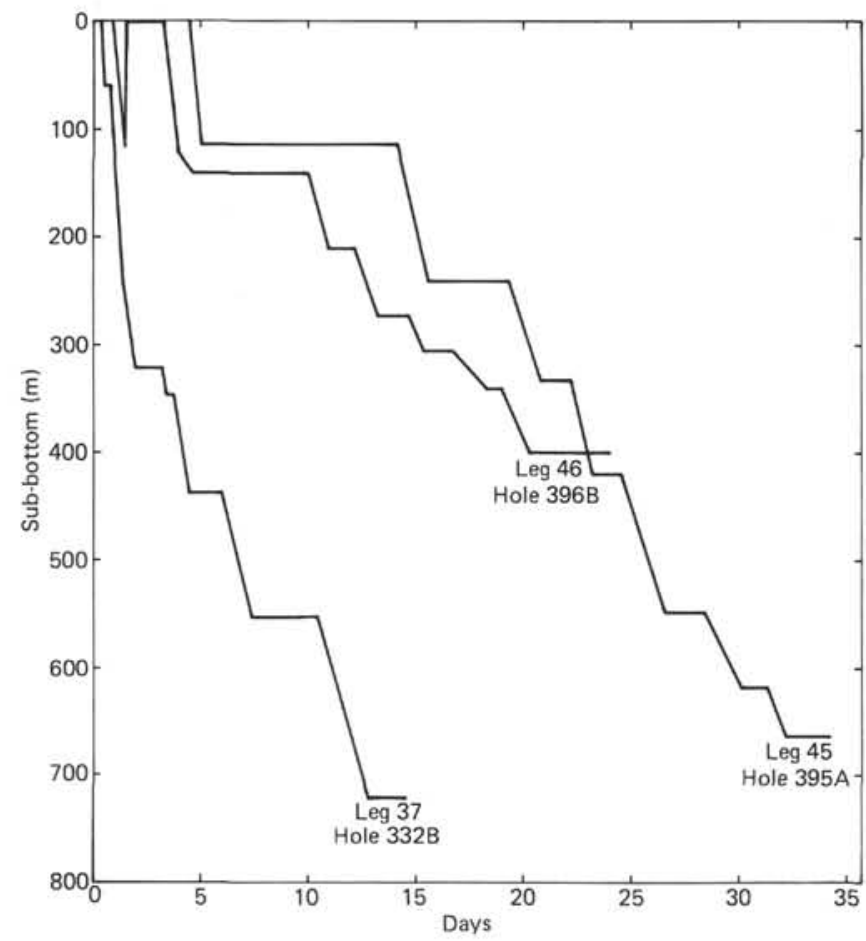

Figure 6. Drilling records for Holes 332B (Leg 37), 395A (Leg 45), and 396B (Leg 46).

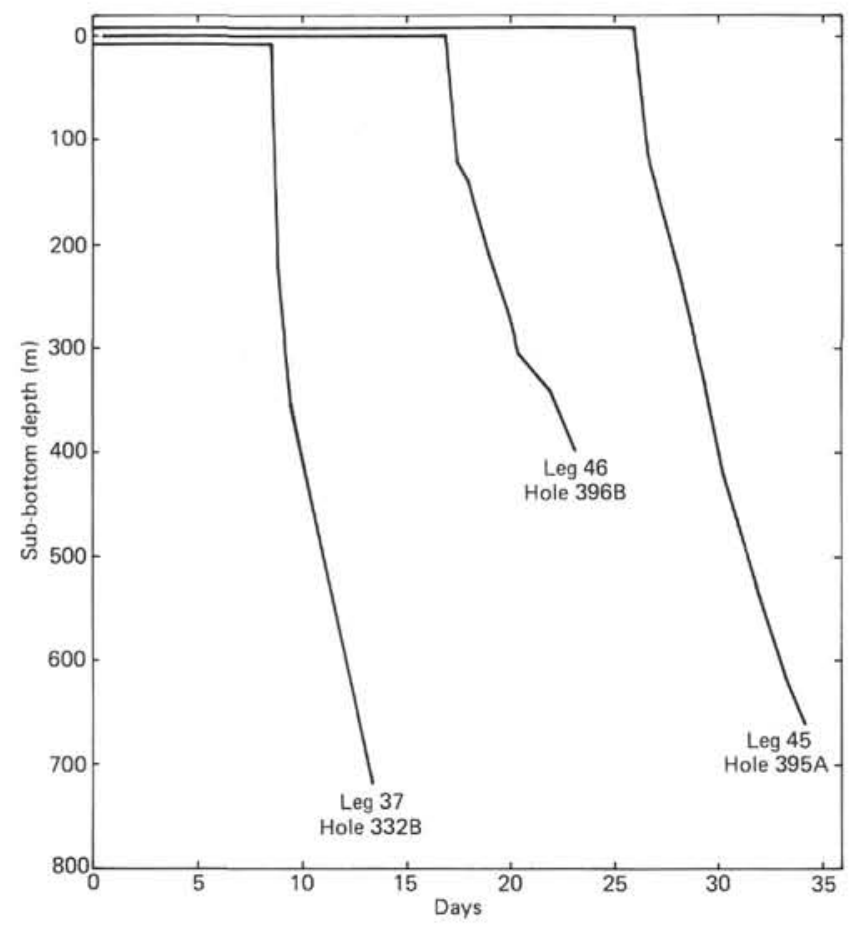

Figure 7. Drilling record for Hole 332B (Leg 37), 395A (Leg 45), 396B (Leg 46) with all drilling time collected in the sloping curves.

The groundmass phases are olivine, plagioclase, clinopyroxene, iron-oxide, sulfide, and glass. Secondary minerals, such as smectite, carbonate zeolite, hematite, and hydro-iron oxides are also present (see section on alteration). The groundmass olivine constitutes 0.5 to 3 per cent of the rock, is often skeletal, and ranges from 0.05 to $0.1 \mathrm{~mm}$. Groundmass plagioclase forms elongated fork-shaped skeletal crystals from 0.1 to $0.8 \mathrm{~mm}$. The groundmass plagioclase thickens from the variolitic zone to the intersertal zone, while its length shows little variation. The clinopyroxene occurs as dendritic feather-like crystals in the groundmass in the microcrystalline spherulitic and intersertal zones.

In some samples mafic, dark-colored, clearly defined, spherules constitute about 1 per cent of the rock. These spherules are 0.1 to $1.0 \mathrm{~mm}$ in diameter and similar to those in the sparsely phyric pillows. The spherules are composed of dendritic crystals of pyroxene (50 to 70\%) with interstitial feldspar and titanomagnetite. Long, tabular, or skeletal fork-shaped idiomorphic plagioclase, which is a major constituent of the groundmass, is lacking.

Figure 13 shows a typical thin section from this unit.

Clastic Zone (315.0 to $405.5 \mathrm{~m}$, Cores 396B-23 to 33)

The last 90 meters of Hole 396B, which we have called the clastic zone, is characterized by very erratic drilling rates $(42.9$ to $3.9 \mathrm{~m} / \mathrm{hr})$ and variable, but generally poor recovery. There was no recovery in three out of eleven cores. The sequence is divided into four units: an upper clastic breccia (Unit 5), an upper basaltic sand and gravel (Unit 6), a plagioclase phyric pillow basalt unit (Unit 7), and a lower basaltic sand and gravel (Unit 8). Sixty per cent of the rock recovered was in the first 19 meters of this section (Cores 23 and 24); with the exception of the penultimate core, only 6 other rock fragments were found in the remaining 71 meters. The high and erratic drilling rates, poor recovery, the presence of sand and gravel in two cores, and the character of the downhole logs (see logging section) suggest that below the breccia this section consists largely of basaltic sand and gravel.

\section{Clastic Breccia}

The clastic breccia in Unit 5 (315 to $340 \mathrm{~m}$, Cores 22 to 26) consists of angular pillow basalt fragments and carbonate-cemented palagonitized basaltic breccia. The relatively coarse pillow basalt fragments consist of fine-grained, sparsely phyric basalt with both olivine and plagioclase phenocrysts. In general, the basalt has only a few fine vesicules. There are five to six pillow rind fragments which grade from aphyric glass at the rim through a variolitic zone into microlitic intersertal basalt inwards. The basalt appears weathered, sometimes with a clayey vuggy appearance and a buff to greenish tint. These basalts are generally more altered than those previously recovered.

In thin section, the basalt has an intersertal to intergranular texture with a fine-grained cryptocrystalline or granular groundmass of clinopyroxene, titanomagnetite, and some olivine in a felty mass of small plagioclase laths. From optical methods, phenocryst plagioclase $(0.2$ to 2.0 $\mathrm{mm}$ ) appears fairly calcic (around $\mathrm{An}_{75}$ ) and somewhat resorbed, while the groundmass laths are more sodic (around $\mathrm{An}_{55}$ ). Olivine phenocrysts are generally idiomorphic and vary from 0.1 to $2.0 \mathrm{~mm}$. Phenocryst spinel is an infrequent accessory, and one euhedral grain was seen in an olivine phenocryst. Secondary alteration products are abundant, with calcite, smectite and zeolites 


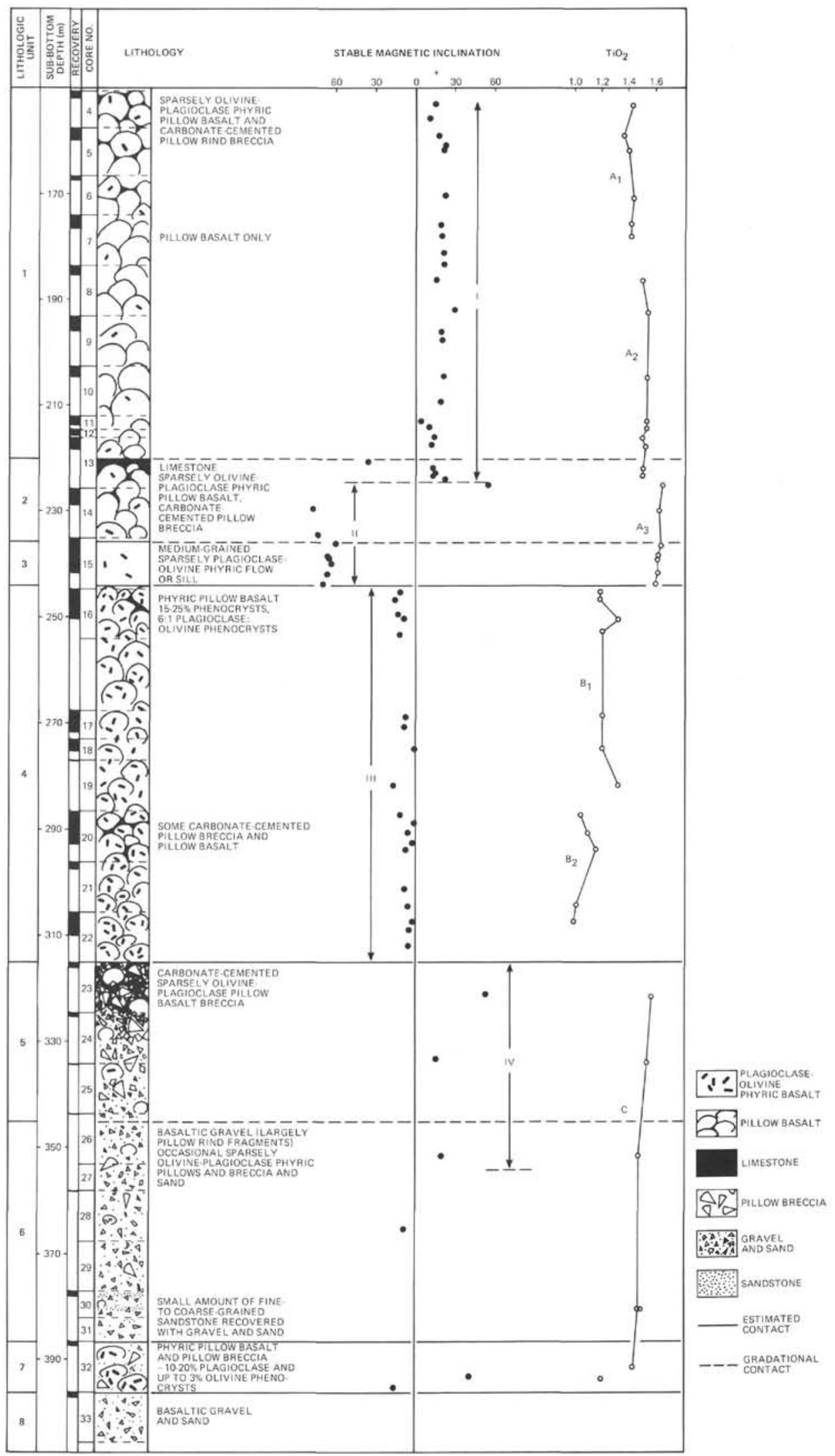

Figure 8. Stratigraphic column, Hole $396 B$. 
TABLE 3

Modal Composition ${ }^{\text {a }}$ of Basalts From Hole 396, Leg 45

\begin{tabular}{ccccccrrrr}
\hline $\begin{array}{c}\text { Chemical } \\
\text { Type }\end{array}$ & $\begin{array}{c}\text { Core }- \\
\text { Section }\end{array}$ & $\begin{array}{c}\text { Piece } \\
\text { No. }\end{array}$ & Olivine & Plagioclase & Groundmass & Vesicles & $\begin{array}{c}\text { Mafic } \\
\text { Spherule }\end{array}$ & $\begin{array}{c}\text { Total } \\
\text { PL/OL }\end{array}$ Phenocryst \\
\hline 1 & $14-6$ & 3 & 0.6 & 6.0 & 92.0 & 0.7 & 0.7 & 10 & 6.6 \\
1 & $22-3$ & 6 & 1.6 & 4.0 & 93.2 & 1.4 & 0.0 & 2.5 & 5.6 \\
2 & $22-4$ & 10 & 1.9 & 14.5 & 83.2 & 0.4 & 0.0 & 7.6 & 16.5 \\
2 & $24-3$ & 12 & 2.1 & 12.6 & 84.8 & 0.2 & 0.3 & 6.0 & 14.7 \\
\hline
\end{tabular}

$a_{1000}$ points for all samples.

TABLE 4

Modal Composition of Phyric Basalt From Hole 396B, Leg 46

\begin{tabular}{|c|c|c|c|c|c|c|c|c|c|c|c|c|}
\hline \multirow[b]{2}{*}{$\begin{array}{l}\text { Chem. } \\
\text { Type }\end{array}$} & \multirow[b]{2}{*}{$\begin{array}{l}\text { Core - } \\
\text { Section }\end{array}$} & \multirow[b]{2}{*}{$\begin{array}{l}\text { Piece } \\
\text { No. }\end{array}$} & \multirow[b]{2}{*}{ Olivine $^{\mathrm{a}}$} & \multirow[b]{2}{*}{ Plagioclase $^{\mathrm{a}}$} & \multirow[b]{2}{*}{ Groundmass } & \multirow[b]{2}{*}{ Vesicle } & \multirow[b]{2}{*}{$\begin{array}{l}\text { Mafic } \\
\text { Spher. }\end{array}$} & \multirow[b]{2}{*}{ Spinel } & \multirow[b]{2}{*}{$\mathrm{PL} / \mathrm{OL}$} & \multirow[b]{2}{*}{$\begin{array}{l}\text { Total } \\
\text { Phen. }\end{array}$} & \multicolumn{2}{|c|}{ Spinel Occurrence } \\
\hline & & & & & & & & & & & $\begin{array}{l}\text { Size } \\
(\mu \mathrm{m})\end{array}$ & $\begin{array}{l}\text { Abund/ } \\
\text { Thin Sect. }\end{array}$ \\
\hline \multirow{7}{*}{ B1 } & $16-1$ & $10 \mathrm{D}_{\mathrm{b}}^{\mathrm{b}}$ & 2.4 & 17.1 & 79.5 & 0.25 & 0.75 & 0.0 & 7.1 & 19.5 & 180 & 1 \\
\hline & $16-2$ & $4 \mathrm{~A}^{\mathrm{b}}$ & 1.3 & 10.35 & 87.55 & 0.3 & 0.5 & 0.0 & 8.0 & 11.65 & & 0 \\
\hline & $16-4$ & $2 \mathrm{~b}$ & 3.2 & 20.4 & 76.1 & 0.3 & 0.0 & 0.0 & 6.4 & 23.6 & 120 & 1 \\
\hline & $17-1$ & $11 \mathrm{~B}^{\mathrm{b}}$ & 2.7 & 13.05 & 82.0 & 1.75 & 0.45 & 0.0 & 4.8 & 15.75 & & 0 \\
\hline & $17=3$ & $2 \mathrm{~B}$ & 3.3 & 17.9 & 78.3 & 0.5 & 0.0 & 0.0 & 5.4 & 21.2 & & 0 \\
\hline & $18-1$ & $7 \mathrm{D}$ & 3.8 & 20.2 & 75.8 & 0.1 & 0.0 & 0.1 & 5.3 & 24.0 & $100-200$ & 2 \\
\hline & $19-1$ & 1 & 1.9 & 14.3 & 83.1 & 0.7 & 0.0 & 0.0 & 7.5 & 16.2 & 360 & 1 \\
\hline \multirow{5}{*}{ B2 } & $20-1$ & $4 B_{b}$ & 3.5 & 20.1 & 75.7 & 0.5 & 0.2 & 0.0 & 5.7 & 23.6 & 80 & 1 \\
\hline & $20-4$ & $11 \mathrm{~A}^{\mathrm{b}}$ & 2.6 & 18.8 & 78.15 & 0.1 & 0.4 & 0.0 & 7.2 & 21.4 & 80 & 2 \\
\hline & $20-5$ & 2 & 3.8 & 13.3 & 82.6 & 0.3 & 0.0 & 0.0 & 3.5 & 17.1 & $80-200$ & 5 \\
\hline & 21.2 & $2^{\mathrm{b}}$ & 3.9 & 19.3 & 76.3 & 0.25 & 0.25 & 0.0 & 5.0 & 23.2 & & 0 \\
\hline & $22-1$ & $11^{\mathrm{b}}$ & 6.0 & 19.8 & 74.8 & 0.2 & 0.15 & 0.05 & 3.3 & 25.8 & $80-200$ & 5 \\
\hline
\end{tabular}

a Phenocryst and microphenocryst.

b 2000 points others 1000 points.

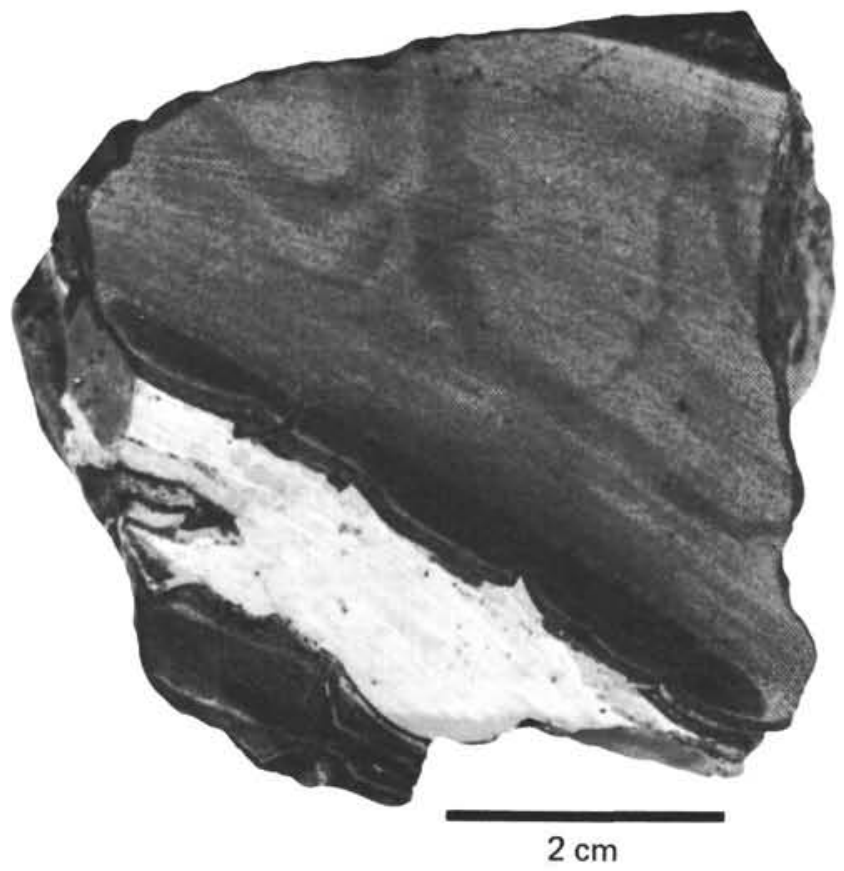

Figure 9. Sample 396B-5-1, 93-98 cm, showing white, lithified sediments and glassy pillow rind. occurring in vugs, vesicules, and the groundmass (see section on alteration).

The basaltic breccia is composed of poorly sorted, sand to gravel-sized chips of glass, variolitic basalt, and intersertal basalt in a crystalline calcite matrix. Basaltic breccia is found as discrete blocks and adhering to the broken surfaces of the pillow fragments. In general, holocrystalline fragments are rare in the breccia, which appears to have been derived largely from pillow rinds. Individual fragments may have calcite-filled vesicles and other evidence of alteration which may have occurred prior to incorporation into the breccia. A larger $(10 \mathrm{~cm})$ piece of the breccia is bedded (Figure 14). The glass in the breccia is generally palagonitized with only a core of fresh black, lustrous glass remaining. The calcite matrix includes numerous small chips of palagonite.

The weathered appearance of the basalt and the presence of the carbonate-cemented breccia on broken pillow fragments suggest that the clastic breccia is a lithified rubble zone.

\section{Upper Gravel Unit}

Recovery in Unit 6 (340.0 to $386.5 \mathrm{~m}$, Cores 396B-26 to 31) was less than $10 \mathrm{~cm}$ of basalt per core. Between 377 and 382 meters (Core 30), a meter of basaltic gravel (Figure 15) was recovered by means of a special plastic sock in the core 


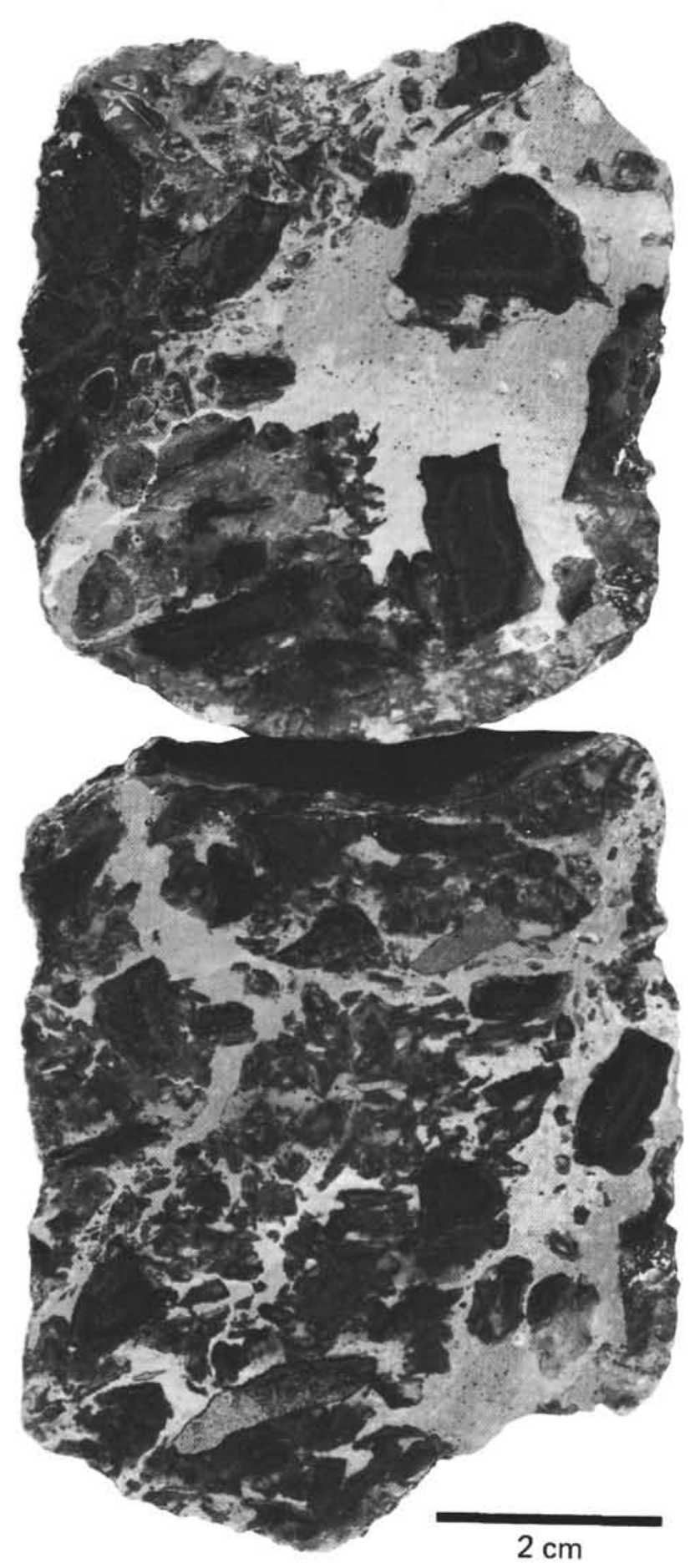

Figure 10. Sample 396B-5-2, 64-68 cm, palagonite breccia with lithified sediment.

catcher. The gravel consists of angular chips of glass, and variolitic, cryptocrystalline, and intersertal basalt. In addition, occasional grains of olivine, plagioclase, and calcite, and a few foraminifers are present. A number of pieces of calcite-cemented basaltic microbreccia, a few chips with calcite spherules, and cross-cutting calcite veins were found. In general, the glass is quite fresh and only a few pieces are palagonitized. The chips are nonvesicular.

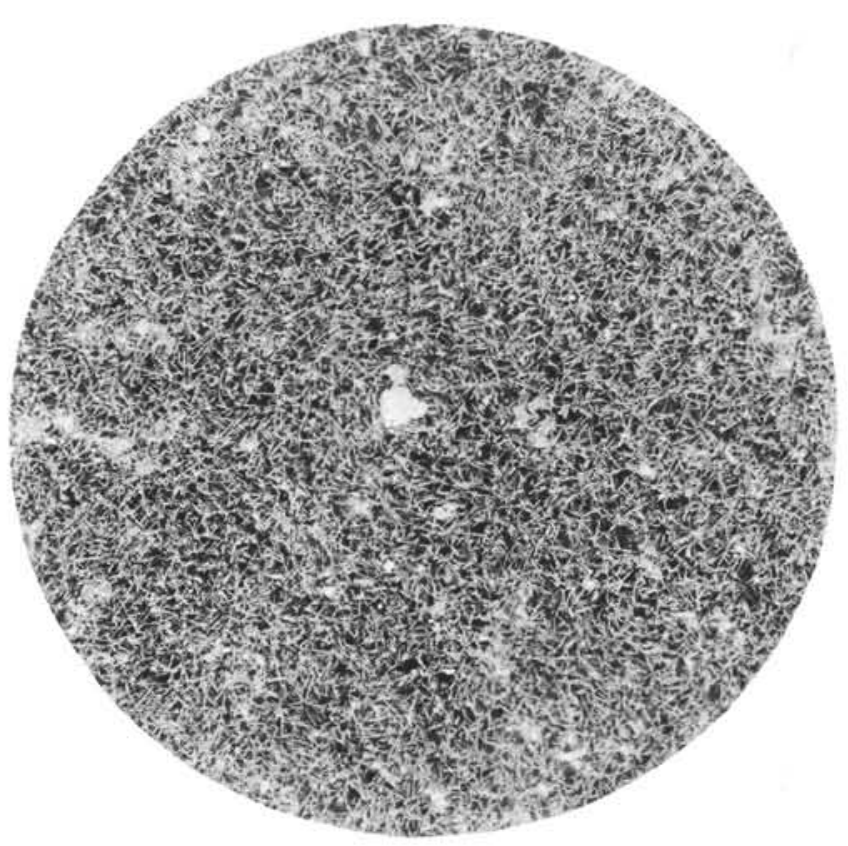

Figure 11. Thin section of Sample 396B-7-3, $13-15 \mathrm{~cm}$, illustrating texture of sparsely phyric pillow interior. Field diameter $=2.54 \mathrm{~cm}$.

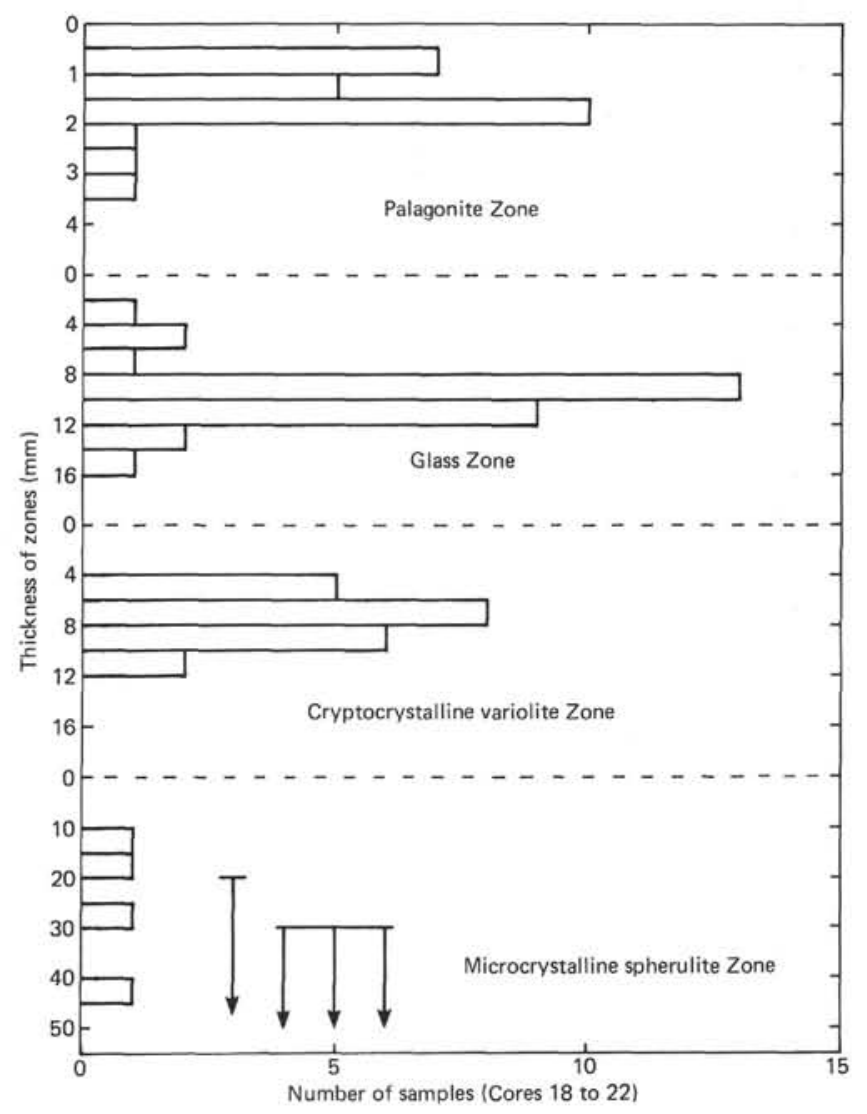

Figure 12. Histogram of zone thicknesses in porphyritic pillows from Hole $396 B$.

Three rock fragments were found with the gravel, a small basalt pillow (about $5 \mathrm{~cm}$ in diameter) and two bedded sandstone fragments (Figure 16). The sandstone is medium 


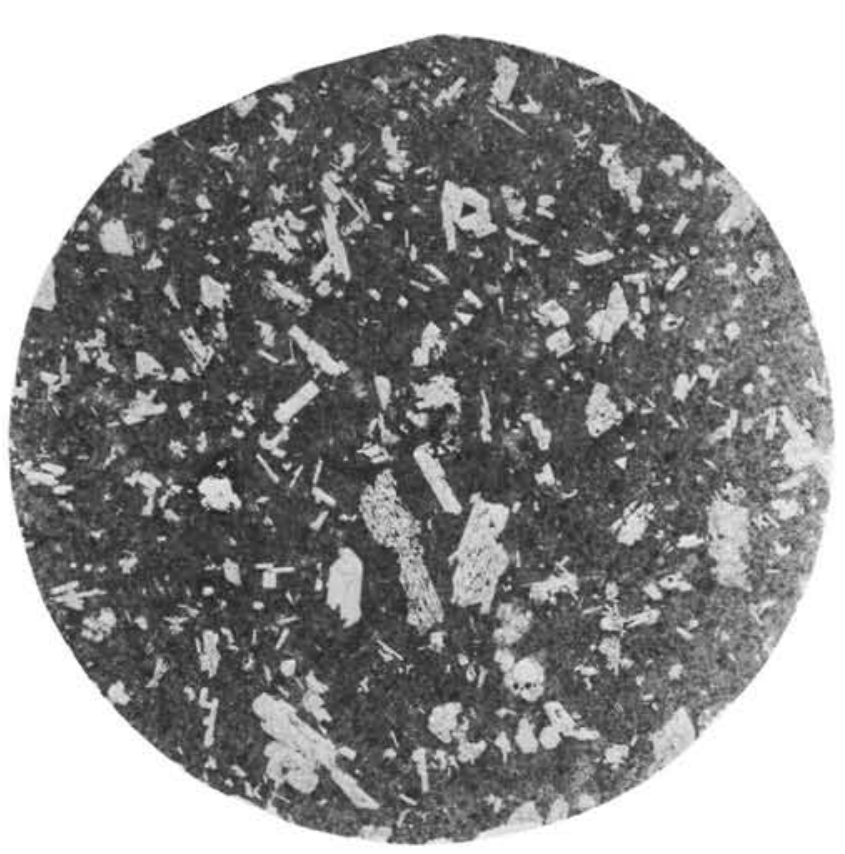

Figure 13. Thin section of Sample 396B-20-4, $71-73 \mathrm{~cm}$, illustrating texture of porphyritic pillow basalt. Field diameter $=2.54 \mathrm{~cm}$.

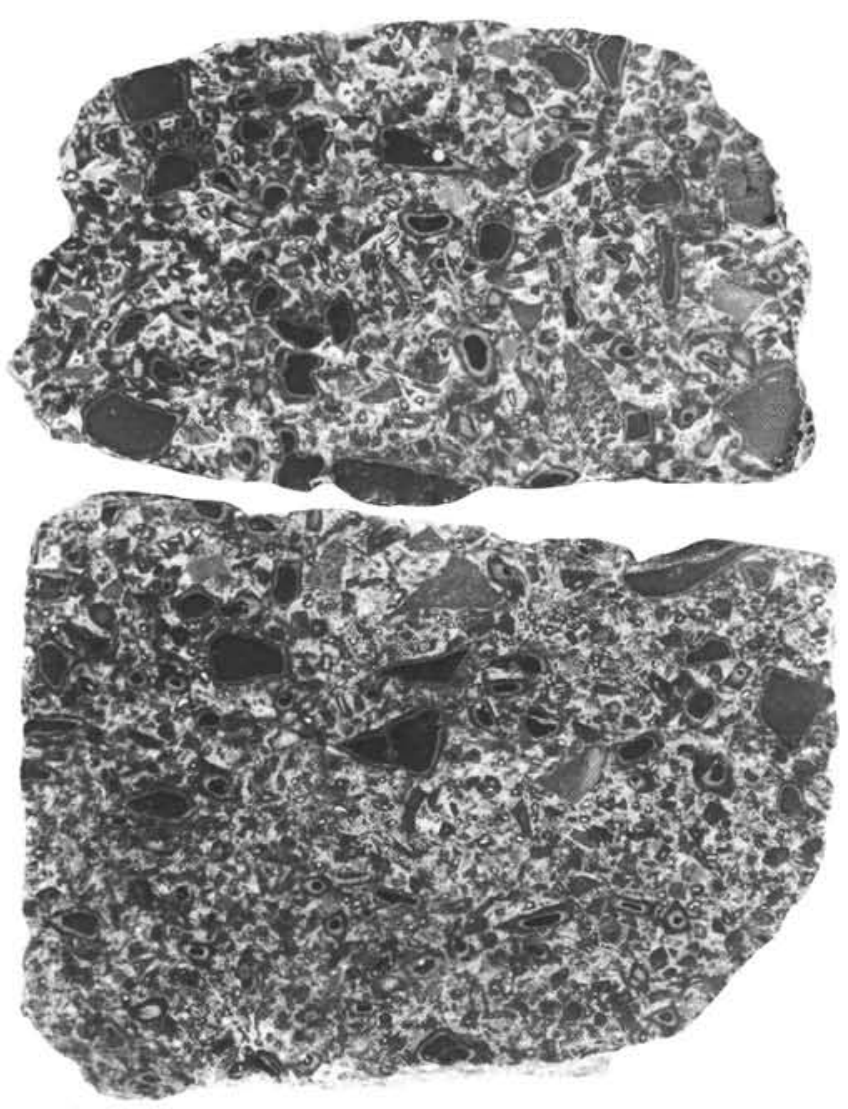

Figure 14. Sample 396B-23-1, 50-59 cm, palagonite breccia. Core diameter $=$ approx. $6 \mathrm{~cm}$. to coarse grained $(0.1$ to $3.0 \mathrm{~mm})$, moderately well sorted, and consists largely of rock and glass fragments like the breccia, although rock fragments are more abundant.

The basalt fragments recovered in this interval are largely sparsely phyric pillow similar to those in the clastic breccia, but noticeably fresher. Four of the six rocks recovered were either small pillows or pillow rind fragments.

The sand and gravel appear to have four possible origins: (1) drilling debris, (2) pyroclastic debris, (3) hyaloclastic debris, and (4) tectonic rubble and scree. The first possibility can be ruled out by the presence of sandstones in the sand and gravel, the occurrence of similar but cemented and palagonitized gravel (Figure 14) in the overlying clastic breccia (Unit 5), the unusual high drilling rates, and the remarkably poor recovery without the use of the plastic sock. A pyroclastic origin seems unlikely at abyssal depths in the oceans, and the absence of vesicules and the presence of breccia fragments and secondary calcite veins in some of the chips seem to rule out such an origin. It is possible that a portion of the gravel originated by spalling and chipping of glass from the quenched crust of moving flows. The calcite fragments, spherulites, lithic fragments with cross-cutting calcite veins, and calcite-cemented basaltic microbreccia fragments, however, demonstrate that a considerable portion of the gravel must be clastic debris from previously altered flows. An origin as tectonic rubble, on the other hand, also appears to fit all the data quite well. The clastic breccia which caps the gravel unit is similar to tectonic rubble photographed and dredged in the FAMOUS region of the Mid-Atlantic Ridge (H. Dick, personal communication). The lack of holocrystalline and predominance of glassy fragments in the sand and gravel may reflect the tendency of pillow rinds to spall and shatter into small fragments while the more massive holocrystalline cores break into larger rock fragments.

\section{Phyric Pillow Basalt}

Unit 7 (386.5 to $396.0 \mathrm{~m}$, Core 396B-32) consists of fragments of phyric to sparsely phyric fresh basalt pillows. The fragments are less altered than those in the clastic breccia unit (Unit 5), are more vesicular, and contain abundant plagioclase phenocrysts. A total of four pillow rind fragments with narrow plagioclase phyric glass rinds were recovered. The most distinctive feature of the unit is the apparent large variation in the amount of phenocrysts in the rocks.

In thin section, the basalt contains from 1 to 15 per cent plagioclase phenocrysts and up to 3 per cent olivine phenocrysts $(0.2$ to $3.0 \mathrm{~mm})$ in a felty groundmass of fine plagioclase laths $(0.1$ to $0.3 \mathrm{~mm})$, intergranular fine-grained or cryptocrystalline clinopyroxene, titanomagnetite, and some olivine. The optically estimated composition of both phenocryst and ground plagioclase is about An66-67, which contrasts with the large differences in the sparsely phyric basalt in the clastic breccia. The plagioclase phenocrysts are typically euhedral in thin section. Olivine occurs as idiomorphic phenocrysts and as fine granular grains in the groundmass. Spinel is a rare accessory in the groundmass. There is also a limited amount of alteration product, 

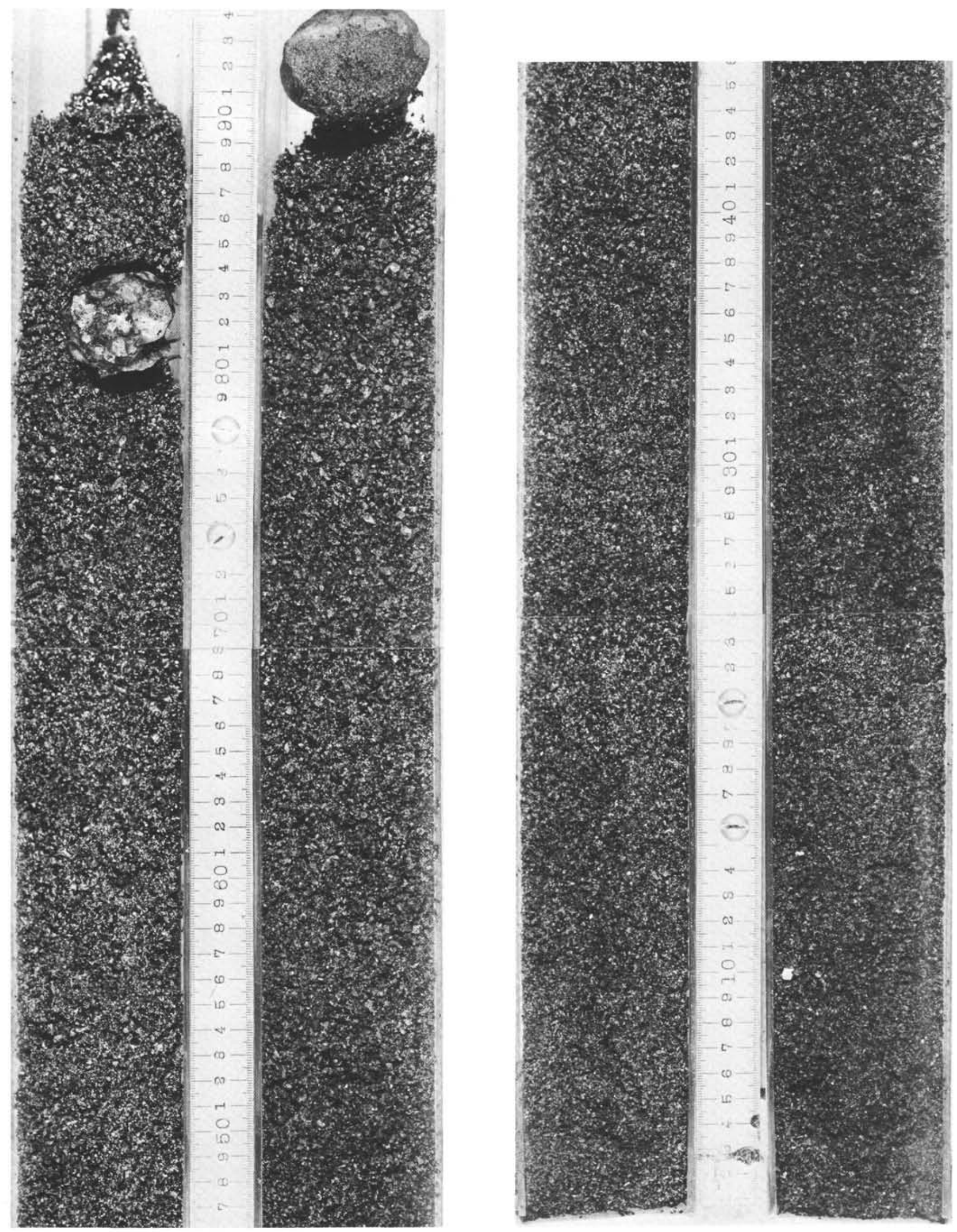

Figure 15. Sand, sandstones, and pillow fragment from Core 396B-30. 


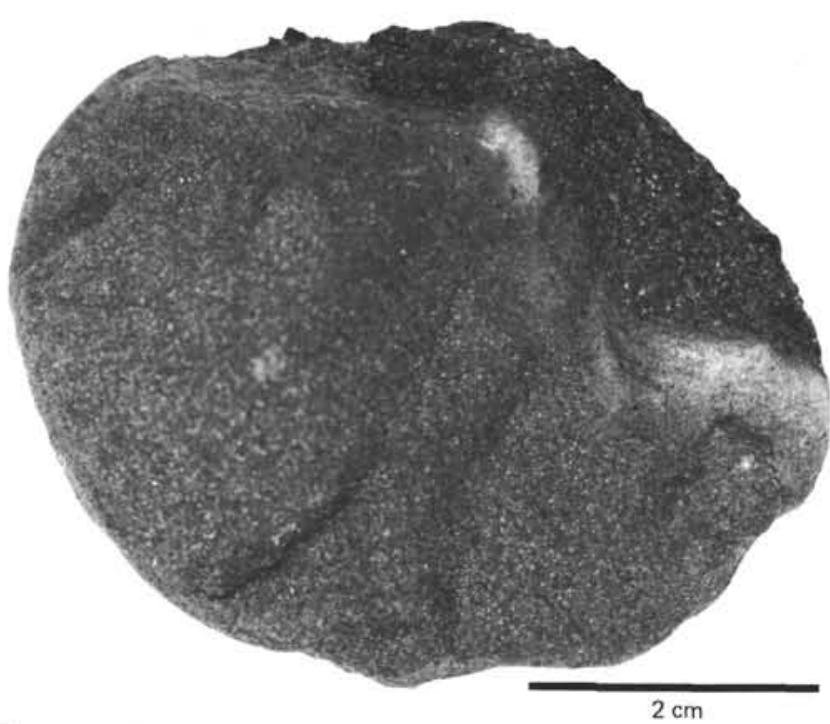

Figure 16. Cut surface of bedded volcanic sandstone from Core 396B-30.

including smectite, iddingsite, and zeolites, as well as some calcite in the groundmass and in amygdule fillings.

\section{Lower Basaltic Sand and Gravel}

In Unit 8 (396.0 to $405.5 \mathrm{~m}$, Core 396B-33), basaltic sand and gravel were recovered. The gravel is similar to that found above the pillow basalt with the exception that glass is less abundant and mineral fragments occur in different proportions (Dick et al.; Schmincke et al., this volume).

\section{Opaque Mineralogy}

The opaque minerals (ore component) in all rocks investigated, apart from Unit 3, are extremely fine grained, and more or less evenly distributed in the silicate groundmass. The ore grains often are smaller than $1 \mu \mathrm{m}$, and dispersed "dustlike" in the groundmass (see Table 5). The ore minerals present are titanomagnetite (responsible for the magnetization of the rocks), sulfides (probably mostly pyrite) and ilmenite (in Unit 3).

Unit 1: The ore minerals present are titanomagnetite and sulfide; no ilmenite has been observed. Titanomagnetite is mostly crystallized in form of skeletons; sulfide present mostly as droplets, often bordering the titanomagnetite crystals (Figure 17). The sulfide is ubiquitous in all samples, but comprises no more than about 10 per cent of the titanomagnetite content.

The titanomagnetites show various stages of oxidation, probably as titanomaghemite in most cases. This oxidation seems to correlate with the alteration of the rock.

Unit 2: Very similar to Unit 1.

Unit 3: The central part of this unit contains relatively coarse-grained ore minerals, the titanomagnetite grains ranging up to $50 \mu \mathrm{m}$. In contrast to the other units, ilmenite is present in this unit and forms separate elongated crystals, equal in amount and size to titanomagnetite.

Magnetic colloid examination shows clearly that the ilmenite is non-magnetic.

Droplets of sulfide often border both titanomagnetite and ilmenite; titanomagnetite crystals have also been observed (Figure 18).
TABLE 5

Ore Microscopy of Basalts From Hole 396B

\begin{tabular}{|c|c|c|}
\hline $\begin{array}{c}\text { Sample } \\
\text { (Interval in } \mathrm{cm} \text { ) }\end{array}$ & Ore Components & $\begin{array}{c}\text { Mean Grain Size } \\
\text { of TiMag }(\mu \mathrm{m})\end{array}$ \\
\hline $4-1-9,103-104$ & $\begin{array}{l}\text { Titanomagnetite (TiM) in } \\
\text { groundmass only, mostly } \\
\text { skeletal sulfides (droplets); } \\
\text { dustlike ore in groundmass }\end{array}$ & $\begin{array}{l}<1 \\
\text { maximum }\end{array}$ \\
\hline $4-2-9,57-59$ & $\begin{array}{l}\text { Skeletal TiM, sulfide here } \\
\text { and in all other samples } \\
\text { sulfide content not more } \\
\text { than about } 10 \% \text { of TiM } \\
\text { content }\end{array}$ & $\begin{array}{l}<1 \\
<1\end{array}$ \\
\hline $5-1-9,86-88$ & Skeletal TiM, sulfide & $<1$ \\
\hline $5-2-6,51-53$ & $\begin{array}{l}\text { Skeletal TiM, sulfide } \\
\text { (droplets) }\end{array}$ & 1 \\
\hline $6-1-7,55-57$ & $\begin{array}{l}\text { Skeletal TiM, sulfide, } \\
\text { mostly as droplets }\end{array}$ & 2 \\
\hline $7-1-7,53-55$ & TiM, droplets of sulfide & $1-2$ \\
\hline $7-1-11 B, 132-134$ & $\begin{array}{l}\text { Somewhat coarser than } \\
\text { Sample } 7-1-7,53-55 \mathrm{~cm} \text {. } \\
\text { Skeletal TiM, droplets of } \\
\text { sulfide }\end{array}$ & 3 \\
\hline $7-2-9,96-98$ & TiM, sulfide & $<1$ \\
\hline $7-3-1 B, 13-15$ & $\begin{array}{l}\text { Skeletal TiM, often border- } \\
\text { ed by droplets of sulfide }\end{array}$ & 3 \\
\hline $8-1-8 A, 62-64$ & Skeletal TiM, sulfide & 3 \\
\hline $8-2-6 A, 60-62$ & Skeletal TiM, sulfide & 3 \\
\hline $9-2-2,19-21$ & Skeletal TiM, sulfide & 2 \\
\hline $10-1-9 A, 51-53$ & Skeletal TiM, sulfide & $<1$ \\
\hline $10-2-4,21-23$ & Skeletal TiM, sulfide & $<1$ \\
\hline $11-2-1,5-7$ & $\begin{array}{l}\text { TiM, tiny droplets of } \\
\text { sulfide }\end{array}$ & 5 \\
\hline $12-1-8,127-129$ & $\begin{array}{l}\text { TiM, tiny droplets of } \\
\text { sulfide }\end{array}$ & 3 \\
\hline $13-1-4,45-47$ & Skeletal TiM, sulfide & 1 \\
\hline $13-3-1,4-6$ & $\begin{array}{l}\text { Skeletal TiM, only very } \\
\text { little sulfide }\end{array}$ & 5 \\
\hline $14-2-2,17-19$ & $\begin{array}{l}\text { Skeletal TiM, droplets of } \\
\text { sulfide }\end{array}$ & 2 \\
\hline $14-3-5 B, 66-68$ & $\begin{array}{l}\text { Skeletal TiM, droplets of } \\
\text { sulfide }\end{array}$ & 5 \\
\hline $15-1-11,85-87$ & $\begin{array}{l}\text { Like Sample } 14-3-5 B \text {, but } \\
\text { less sulfide }\end{array}$ & 3 \\
\hline $15-2-20,129-131$ & $\begin{array}{l}\text { TiM, ilmenite (tested by } \\
\text { magnetic colloid), sulfide }\end{array}$ & 20 \\
\hline $15-3-2 B, 16-19$ & Like Sample 15-2-20 & 15 \\
\hline $15-3-3 A, 79-82$ & $\begin{array}{l}\text { Like Sample } 15-2-20 \text {, but } \\
\text { much less ilmenite }\end{array}$ & 10 \\
\hline $15-4-4,76-79$ & $\begin{array}{l}\text { Like Sample } 15-2-20 \text {, TiM, } \\
\text { ilmenite, sulfide }\end{array}$ & 15 \\
\hline $16-1-10 \mathrm{D}, 83-85$ & $\begin{array}{l}\text { TiM, bordered with tiny } \\
\text { sulfide spherules, very little } \\
\text { ilmenite? }\end{array}$ & 3 \\
\hline $16-2-4 A, 40-42$ & $\begin{array}{l}\text { Similar to } 16-1-10 \mathrm{D} \text {, but } \\
\text { more fine grained }\end{array}$ & 1 \\
\hline $16-4-2,20-22$ & TiM, sulfide & 3 \\
\hline $17-1-11 \mathrm{~B}, 132-134$ & Skeletal TiM, some sulfide & 3 \\
\hline $17-3-2 B, 33-35$ & Skeletal TiM, some sulfide & 2 \\
\hline 18-1-7D, $117-119$ & Skeletal TiM, some sulfide & 5 \\
\hline $20-1-4 B, 53-55$ & Skeletal TiM, some sulfide & 5 \\
\hline
\end{tabular}


TABLE 5 - Continued

\begin{tabular}{|c|c|c|}
\hline $\begin{array}{c}\text { Sample } \\
\text { (Interval in } \mathrm{cm} \text { ) }\end{array}$ & Ore Components & $\begin{array}{l}\text { Mean Grain Size } \\
\text { of TiMag }(\mu \mathrm{m})\end{array}$ \\
\hline $20-4-11 \mathrm{~A}, 71-73$ & $\begin{array}{l}\text { Mostly skeletal TiM, some } \\
\text { sulfide }\end{array}$ & 1.5 \\
\hline $20-5-2,16-18$ & $\begin{array}{l}\text { Mostly skeletal TiM, some } \\
\text { sulfide }\end{array}$ & 2 \\
\hline $21-2-2,24-26$ & $\begin{array}{l}\text { Mostly skeletal TiM, some } \\
\text { sulfide }\end{array}$ & 2 \\
\hline $22-1-11,93-95$ & $\begin{array}{l}\text { Mostly skeletal TiM, some } \\
\text { sulfide }\end{array}$ & 1.5 \\
\hline $23-1-12 B, 80-82$ & $\begin{array}{l}\text { Mostly skeletal TiM, some } \\
\text { sulfide }\end{array}$ & 1.5 \\
\hline $24-1-15 \mathrm{~A}, 94-96$ & $\begin{array}{l}\text { TiM, of ten skeletal, some } \\
\text { sulfide as tiny spherules }\end{array}$ & 1 \\
\hline $26-1-1,7-10$ & $\begin{array}{l}\text { Extremely fine ore grains, } \\
\text { probably TiM and sulfides }\end{array}$ & $<1$ \\
\hline $28-1-2,10-12$ & $\begin{array}{l}\text { TiM, mostly skeletal. Minor } \\
\text { amount of sulfides; some } \\
\text { TiM grains up to } 10 \mu \mathrm{m} ; \\
\text { signs of magnetization }\end{array}$ & 3 \\
\hline $32-1-10,69-71$ & $\begin{array}{l}\text { TiM, mostly skeletal, often } \\
\text { bordered by tiny droplets } \\
\text { of sulfide }\end{array}$ & $2-3$ \\
\hline
\end{tabular}

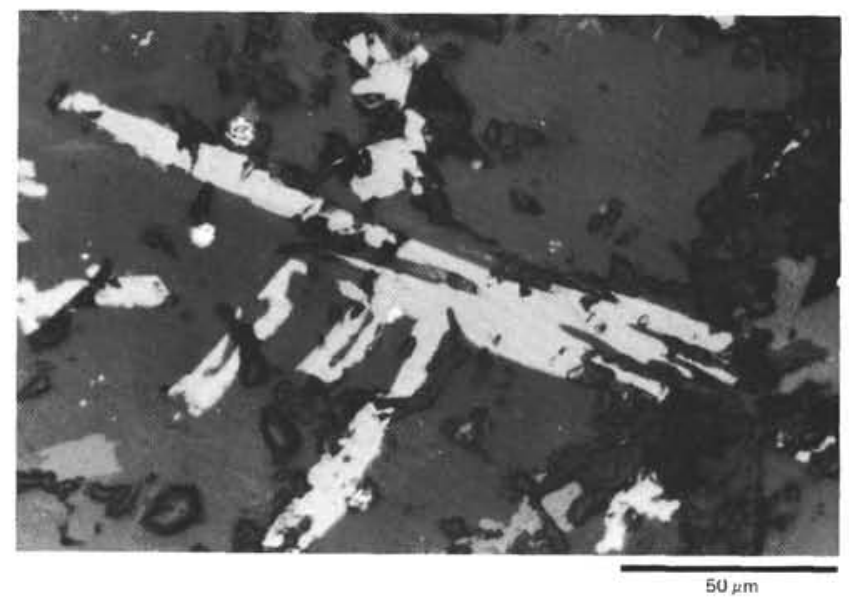

Figure 17. Skeletal, very fine grained titanomagnetite (light gray) in a groundmass of plagioclase (dark gray), pyroxene (medium gray), and glass (dark gray, slightly spotted). Droplets of sulfide (white), probably pyrite, in the center of the photograph. Sample 396B-7-3-1B, 13-15 $\mathrm{cm}$.

Unit 4: Very similar to Unit 1. Table 5 gives a brief description of the ore components in the different samples investigated.

\section{Alteration}

Figure 19 presents, in addition to information about the lithologic column, the following data about fracturing and the alteration of non-glassy basalts from Hole 396B:

1) The number of glassy rock samples (pillow rind, pillow breccia, and hyaloclastite) and the total number of pieces. These pairs of figures give an idea of the location of the largest scale initial porosity within the various units.

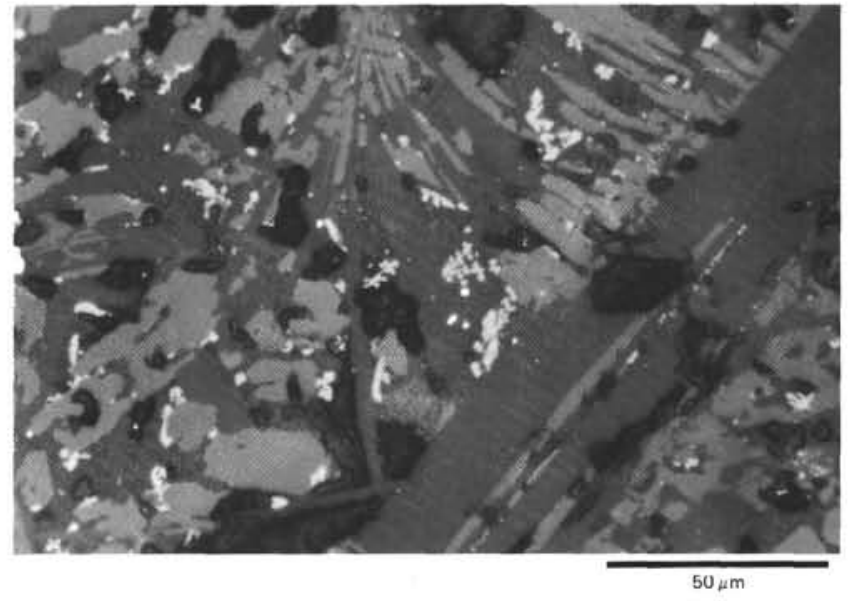

Figure 18. Relatively coarse grained ilmenite (elongated grains, light gray). In the center of the photograph is a droplet of sulfide (white), bordering ilmenite. Sample 396B-15-2-20, 129-131.

2) The number of samples in each core which display one of the five following alteration degrees as distinguished on the basis of matrix color: the freshest (dark gray), the almost fresh (gray), the moderately altered (dark brownish grav). the very altered (grayish brown), and the most altered (light yellowish brown) basalt. The "moderately altered" category actually comprises samples which, on the basis of megascopic features, could not be classified either as "'almost fresh"' (gray) or "very altered"' (brown) basalts.

The "alteration degree band" is the envelope which comprises the major part of the samples in each core exhibiting the most common alteration degree. The variations of the band width and shape are related to "spread" through the five degrees of alteration of two-thirds of the samples within one core. One can notice six (maybe seven) zones of more severe alteration corresponding to six (or seven) maxima of the "alteration degree band": (a) the uppermost three, Cores 4, 5, and 6; (b) Core 9; (c) Core 13; (d) Core 16; (e) Core 20; (f) Cores 23 and 24; and (g) Cores 28 and 32 (but these have the low recovery and any statement is difficult to justify statistically).

3) The frequency and nature (ooze, carbonates and/or zeolites, Mn, and smectite) of the fractures and veins. The estimated fracture frequencies range from very high, to high, low, and very low; however, these characteristics must be carefully interpreted because the probability of observing fractures directly depends on the sample size.

4) The number of vug-bearing samples, where vugs are defined as $>1-\mathrm{mm}$ voids exhibiting irregular outlines.

5) The abundance and nature of the vescicle fillings. The estimated abundance (volume \%) reflects vesicles not including the vugs (see " 3 "' above). Vesicles are defined as $<1$-mm voids displaying rounded outlines.

6) The number of iddingsitized olivine-bearing samples.

In Figure 19, the above characteristics are compared to the lithologic column which portrays the frequency of pillow rind, the presence of pillow breccia and hyaloclastite, as well as the presence of indurated ooze horizons or veins are symbolically represented.

These data are very crude estimates, but represent a first attempt at correlating alteration features and structural 


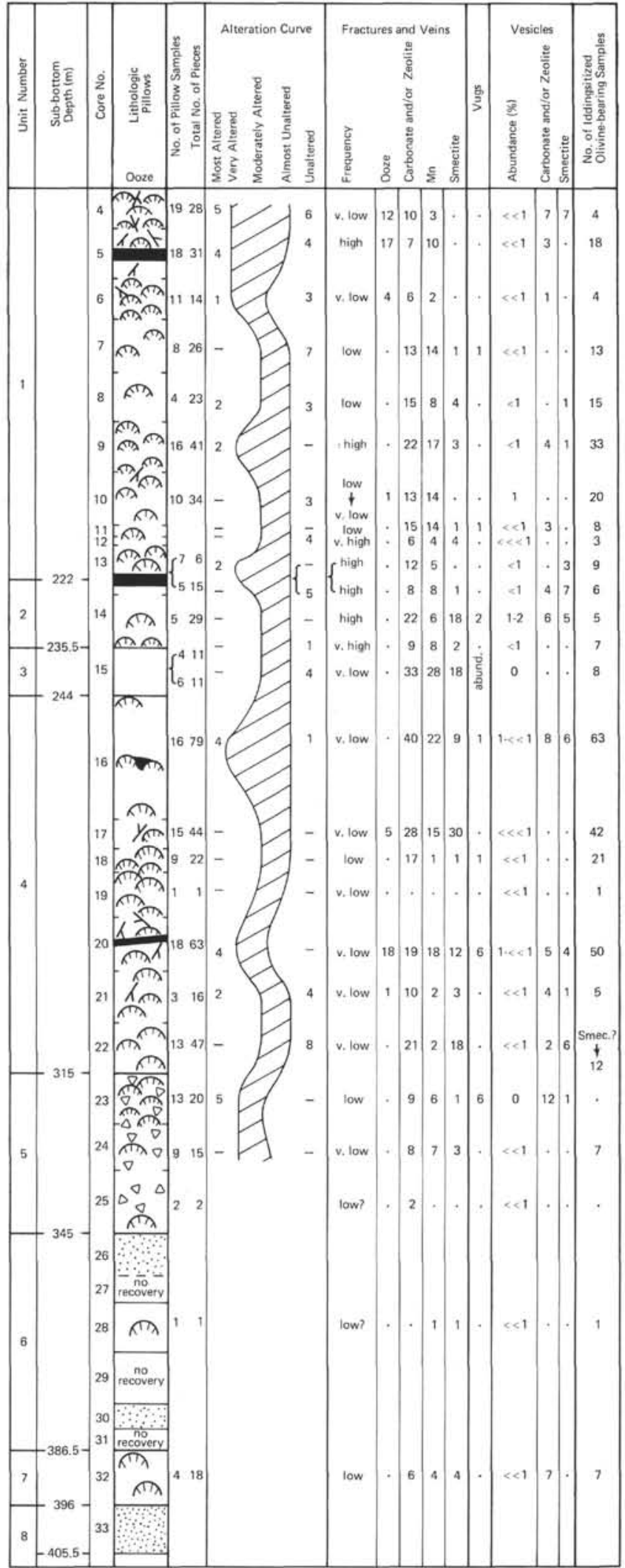

Figure 19. Stratigraphic column of Hole 396B illustrating variations in alteration and fracturing. characteristics of the various units. The following preliminary conclusions are suggested:

1) The vesicularity is not related to the degree of alteration, probably because the vesicle volume is always very small (from 1 to a few \%) when discernibly present.

2) The nature of the vesicle fillings in one core is generally related to that of the fracture fillings in the same core; i.e., when either the secondary minerals (calcite, phillipsite) or smectite are unusually abundant in the vesicles, they also appear to be abundant in the veins. Mn-oxide was found both in the vesicles and, more frequently, on the fracture walls.

3) The vugs are practically always partly filled with white secondary minerals, but their presence does not seem to coincide with the alteration zonation. The "cooling unit" (Unit 3) might be the only exception. It is not possible at this point to decide whether the alteration of the samples containing the large voids is due to pneumatolysis or to sea-water weathering. Further study will attempt to solve this question.

4) Indurated ooze horizons or fracture fillings are found in the close vicinity of the core portions which display the alteration maxima, i.e., the largest number of samples with stronger alteration (see Figure 19). However, no consistent spatial or sequential relationship appears between alteration maxima and sedimentary episodes. This lack of coincidence could be merely apparent, because the alteration maxima were plotted at the center of the column length corresponding to each core and not where the maxima were actually located within each core.

5) The alteration maxima do not coincide with the fracture frequency.

6) The cores displaying the highest number of iddingsitized olivine phenocrysts are generally those which also have the alteration maxima.

Finally, there appears to be a good correlation between the "alteration band" and the logging data, especially between extensive alteration and high neutron porosity and low resistivity.

\section{Mineralogy of the Alteration Products}

Although the accurate identification of secondary minerals resulting from the alteration of basalts necessitates methods and instruments (X-ray diffraction camera and microprobe) which were not available onboard Glomar Challenger, the following major groups of alteration products could be recognized:

1) Calcite-forming fibroradial aggregates and botryoidal concretions, as the filling of fissures, voids, and vesicles;

2) Phillipsite exhibiting various habits (fibrous, botryoidal aggregates and crusts) mainly in vesicles and in the fissures;

3) Smectites of various colors (from light grayish blue to deep green, yellow, orange, etc.) as lining on the vesicle and fracture walls;

4) Manganese oxide crust and specks, mainly on the fracture walls;

5) $\mathrm{Fe}-\mathrm{Mn}$ hydroxides also stain the phillipsite fissure fillings with colors ranging from bright yellow, to orange and deep red. 
TABLE 6

Compositions of Basalts From Hole 396B

\begin{tabular}{|c|c|c|c|c|c|c|c|c|c|c|}
\hline $\begin{array}{l}\text { Sample (Interval in } \mathrm{cm} \text { ) } \\
\text { Approx, depth }(\mathrm{m})^{\mathrm{a}} \\
\text { Rock Type } \\
\text { Chemical Type } \\
\text { Lithologic Unit }\end{array}$ & $\begin{array}{c}\text { 4-1, } 103-105 \\
151.5 \\
\text { Basalt } \\
\text { A1 } \\
1\end{array}$ & $\begin{array}{c}5-1,86-88 \\
157.9 \\
\text { Basalt } \\
\text { A1 } \\
1\end{array}$ & $\begin{array}{c}5-2,51-53 \\
159.0 \\
\text { Basalt } \\
\text { A1 } \\
1\end{array}$ & $\begin{array}{c}6-1,55-57 \\
167.0 \\
\text { Basalt } \\
\text { A1 } \\
1\end{array}$ & $\begin{array}{c}7-1,53-55 \\
174.5 \\
\text { Basalt } \\
\text { A1 } \\
1\end{array}$ & $\begin{array}{c}7-1,132-134 \\
175.4 \\
\text { Basalt } \\
\text { A1 } \\
1\end{array}$ & $\begin{array}{c}8-1,62-64 \\
184.1 \\
\text { Basalt } \\
\text { A2 } \\
1\end{array}$ & $\begin{array}{c}8-2,60-62 \\
185.6 \\
\text { Basalt } \\
\text { A2 } \\
1\end{array}$ & $\begin{array}{c}10-1,51-53 \\
203.0 \\
\text { Basalt } \\
\text { A2 } \\
1\end{array}$ & $\begin{array}{c}11-1,56-58 \\
212: 5 \\
\text { Basalt } \\
\text { A2 } \\
\text { I }\end{array}$ \\
\hline \multicolumn{11}{|l|}{ Major Element (\%) } \\
\hline $\mathrm{SiO}_{2}$ & 49.91 & 49.69 & 49.66 & 50.053 & 49,42 & 49.42 & 49.96 & 50.13 & 49.85 & 49.82 \\
\hline $\mathrm{Al}_{2} \mathrm{O}_{3}$ & 15.51 & 15.65 & 15.28 & 16.14 & 15.63 & 15.30 & 15.38 & 15.30 & 15.41 & 15.28 \\
\hline $\mathrm{Fe}_{2} \mathrm{O}_{3}$ (total $\mathrm{Fe}$ ) & 10.20 & 10.01 & 10.21 & 9.58 & 10.47 & 10.42 & 10.61 & 10.29 & 10.90 & 10.71 \\
\hline $\mathrm{MgO}$ & 7.88 & 8.05 & 7.96 & 7.66 & 8.03 & 8.02 & 7.93 & 7.17 & 7.70 & 7.77 \\
\hline $\mathrm{CaO}$ & 11.87 & 11.30 & 12.03 & 12.24 & 11.82 & 11.70 & 11.50 & 11.80 & 1.79 & 11.79 \\
\hline $\mathrm{Na}_{2} \mathrm{O}$ & 2.57 & 2.55 & 2.57 & 2.66 & 2.56 & 2.68 & 2.58 & 2.76 & 2.68 & 2.63 \\
\hline $\mathrm{K}_{2} \mathrm{O}$ & 0.28 & 0.18 & 0.29 & 0.25 & 0.19 & 0.25 & 0.31 & 0.27 & 0.17 & 0.20 \\
\hline $\mathrm{TiO}_{2}$ & 1.43 & 1.37 & 1.40 & 1.44 & 1.42 & 1.42 & 1.51 & 1.55 & 1.54 & 1.54 \\
\hline $\mathrm{P}_{2} \mathrm{O}_{5}$ & 0.15 & 0.14 & 0.12 & 0.14 & 0.14 & 0.14 & 0.16 & 0.14 & 0.15 & 0.14 \\
\hline $\mathrm{MnO}$ & 0.18 & 0.18 & 0.17 & 0.17 & 0.19 & 0.18 & 0.19 & 0.19 & 0.20 & 0.20 \\
\hline Total & 99.98 & 99.12 & 99.69 & 100.31 & 99.87 & 99.53 & 100.13 & 99.60 & 100.34 & 100.08 \\
\hline Loss of lgnition & -1.67 & -0.93 & -1.79 & -2.64 & -1.27 & -2.01 & -2.08 & -3.57 & -1.43 & -1.39 \\
\hline $\mathrm{H}_{2} \mathrm{O}^{+}$ & .93 & .75 & 0.77 & .94 & 0.81 & 0.97 & 1.24 & 1.21 & 0.83 & 0.83 \\
\hline $\mathrm{CO}_{2}$ & .14 & .13 & 0.37 & .22 & 0.23 & 0.13 & 0.16 & 0.40 & 0.19 & 0.17 \\
\hline $\mathrm{Mg} /(\mathrm{Mg}+\mathrm{Fe})$ & 0.60 & 0.61 & 0.61 & 0.61 & 0.60 & 0.60 & 0.60 & 0.58 & 0.58 & 0.59 \\
\hline \multicolumn{11}{|l|}{ Trace Element (ppm) } \\
\hline $\mathrm{Cr}$ & 355.0 & 358.0 & 327.0 & 341.0 & 357.0 & 345.0 & 308.0 & 293.0 & 319.0 & 310.0 \\
\hline $\mathrm{Ni}$ & 146.0 & 124.0 & 140.0 & 138.0 & 133.0 & 133.0 & 124.0 & 130.0 & 120.0 & 122.0 \\
\hline $\mathrm{Sr}$ & 126.0 & 118.0 & 120.0 & 146.0 & 122.0 & 124.0 & 131.0 & 141.0 & 128.0 & 126.0 \\
\hline $\mathrm{Zr}$ & 97.0 & 89.0 & 95.0 & 90.0 & 99.0 & 96.0 & 92.0 & 109.0 & 111.0 & 103.0 \\
\hline
\end{tabular}

TABLE 6 - Continued

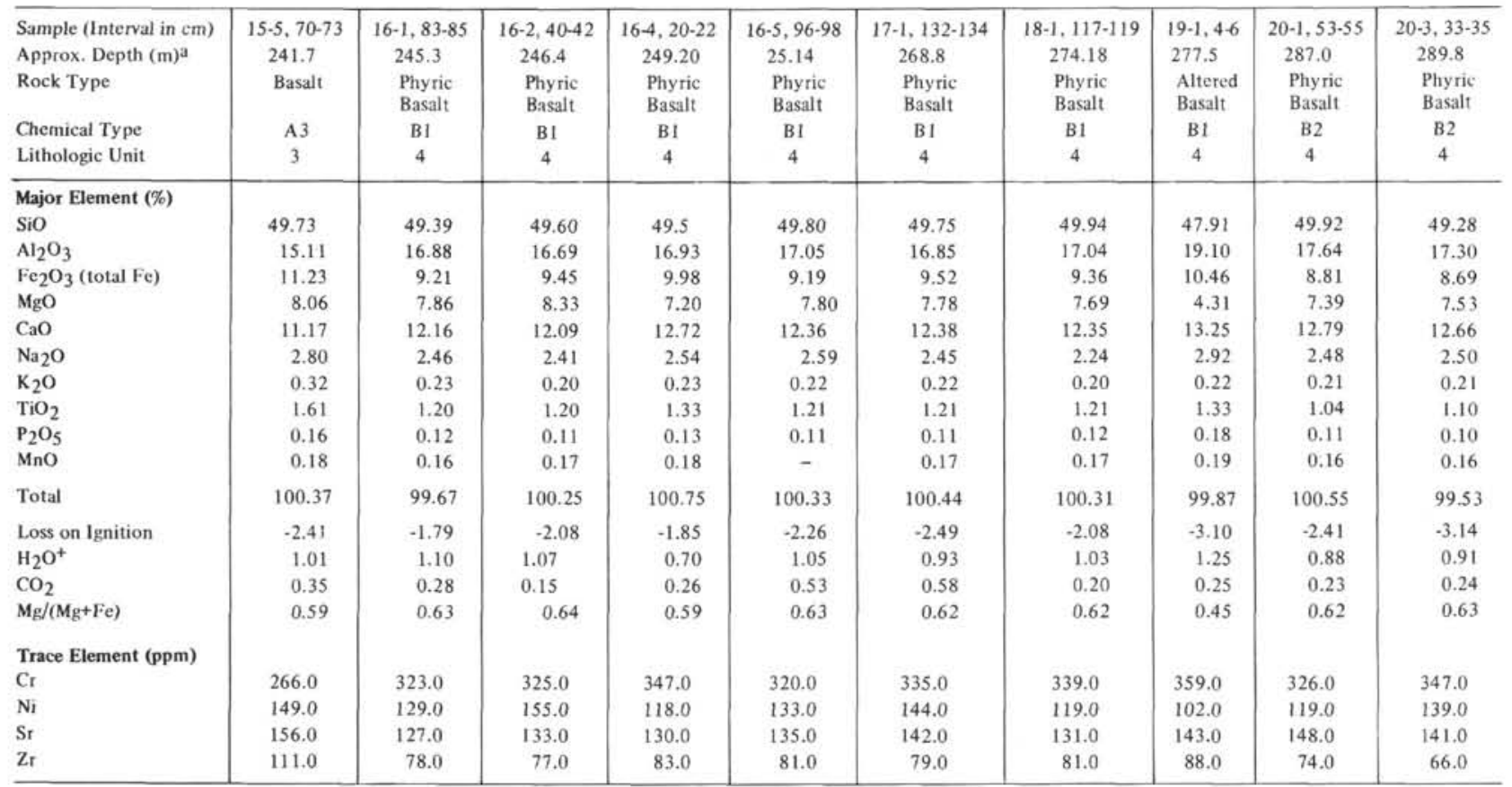

\section{Chemistry of the Alteration Process of the Non-Glassy Basalts}

This topic is discussed in detail in a paper dedicated to the alteration (Honnorez et al., this volume). Unexpectedly, one finds no enrichment of $\mathrm{K}_{2} \mathrm{O}$; instead, there is a depletion in $\mathrm{MgO}$ and $\mathrm{SiO}_{2}$ where zeolites, smectites, and carbonates are observed. These chemical variations are related to increases of $\mathrm{CO}_{2}$ and water contents $\left(\mathrm{H}_{2} \mathrm{O}^{+}\right)$, and oxidation coefficient $\left(\mathrm{Fe}_{2} \mathrm{O}_{3} / \mathrm{FeO}+\mathrm{Fe}_{2} \mathrm{O}_{3}\right)$.

\section{Alteration of the Basaltic Glass}

A general observation through all the cores is the absence of severe alteration of the glassy pillow rinds even when they are associated with very altered adjacent variolitic and/or inner microlitic zones. This observation is all the more remarkable as basaltic glasses are chemically much more unstable than the microlitic or variolitic lavas. It seems that the variolitic zone is often more strongly altered 
TABLE 6 - Continued

\begin{tabular}{|c|c|c|c|c|c|c|c|c|c|c|}
\hline $11-2,5-7$ & $12 \cdot 1,127-129$ & $13-1,45-47$ & $13-2.49-51$ & $13-2,89-91$ & $13-3,4-6$ & $14-2,17-19$ & $15-1,85-87$ & $15-2,129-131$ & $15-3,16-19$ & $15-4.76-79$ \\
\hline 213.55 & 215.8 & 216.4 & 218.0 & 218.4 & 219.0 & 235.85 & 235.85 & 237.8 & 238.1 & 240.2 \\
\hline Basalt & Basalt & Basalt & Basalt & Basalt & Basalt & Basalt & Basalt & Basalt & Basalt & Basalt \\
\hline $\mathrm{A} 2$ & A2 & $\mathrm{A} 2$ & $\mathrm{~A} 2$ & $\mathrm{~A} 2$ & A3 & A3 & $\mathrm{A} 3$ & A3 & A3 & A3 \\
\hline 1 & 1 & 1 & 2 & 2 & 2 & 2 & 3 & 3 & 3 & 3 \\
\hline 50.21 & 50.00 & 49.86 & 50.30 & 50.14 & 50.11 & 49.70 & 49.96 & 49.90 & 50.36 & 49.84 \\
\hline 15.39 & 15.07 & 15.28 & 15.10 & 15,41 & 15.53 & 15.30 & 15.14 & 14.98 & 15.24 & 15.01 \\
\hline 10.61 & 10.49 & 10.65 & 10.26 & 10.29 & 10.57 & 10.81 & 11.01 & 11.20 & 11.04 & 11.15 \\
\hline 7.87 & 7.76 & 8.16 & 7.50 & 7.64 & 7.42 & 7.60 & 7.49 & 7.93 & 7.68 & 8.05 \\
\hline 11.74 & 11.50 & 11.60 & 11.50 & 11.68 & 11.32 & 11.10 & 11.17 & 11.01 & 11.05 & 11.00 \\
\hline 2.49 & 2.78 & 2.64 & 2.66 & 2.67 & 2.88 & 2.83 & 2.91 & 2.68 & 2.72 & 2.71 \\
\hline 0.25 & 0.29 & 0.25 & 0.26 & 0.28 & 0.27 & 0.29 & 0.29 & 0.14 & 0.15 & 0.15 \\
\hline 1.54 & 1.51 & 1.53 & 1.51 & 1.51 & 1.67 & 1.64 & 1.65 & 1.63 & 1.63 & 1.63 \\
\hline 0.14 & 0.14 & 0.16 & 0.14 & 0.16 & 0.15 & 0.16 & 0.16 & 0.17 & 0.16 & 0.15 \\
\hline 0.18 & 0.18 & 0.18 & 0.17 & 0.17 & 0.17 & 0.17 & 0.17 & 0.17 & 0.17 & 0.18 \\
\hline 100.41 & 99.72 & 100.31 & 99.40 & 99.95 & 100.09 & 99.70 & 99.95 & 99.81 & 100.20 & 399.87 \\
\hline-2.23 & .2 .96 & -2.06 & -2.74 & -3.16 & -2.99 & -2.54 & -2.88 & -1.70 & -2.52 & -1.86 \\
\hline 0.95 & 1.30 & 0.86 & 1.35 & 1.23 & 1.36 & 1.08 & 1.25 & 0.90 & 0.89 & 0.92 \\
\hline 0.32 & 0.18 & 0.18 & 0.31 & 0.22 & 0.15 & 0,14 & 0.34 & 0.13 & 0.27 & 0.26 \\
\hline 0.60 & 0.59 & 0.60 & 0.59 & 0.60 & 0.59 & 0.58 & 0.57 & 0.58 & 0.58 & 0.59 \\
\hline 292.0 & 296.0 & 323.0 & 300.0 & 300.0 & 297.0 & 297.0 & 285.0 & 266.0 & 263.0 & 267.0 \\
\hline 131.0 & 126.0 & 131.0 & 138.0 & 145.0 & 156.0 & 155.0 & 150.0 & 119.0 & 119.0 & 116.0 \\
\hline 132.0 & 136.0 & 124.0 & 130.0 & 144.0 & 146.0 & 143.0 & 146.0 & 142.0 & 140.0 & 142.0 \\
\hline 103.0 & 99.0 & 100.0 & 99.0 & 94.0 & 126.0 & 129.0 & 119.0 & 124.0 & 116.0 & 117.0 \\
\hline
\end{tabular}

TABLE 6 - Continued

\begin{tabular}{|c|c|c|c|c|c|c|c|c|c|}
\hline $20-5,16-18$ & $21-2,24-26$ & $22 \cdot 1,93-95$ & $23-1,87-89$ & $24-1,94-96$ & $26-1,7-10$ & $30-1,60.0$ & $30-1,60.0$ & $32 \cdot 1,45-47$ & $32-1,69-71$ \\
\hline 291.2 & 297.7 & 306.4 & 315.9 & 325.5 & 343.6 & 377.6 & 377.6 & 386.95 & 387.20 \\
\hline $\begin{array}{l}\text { Phyric } \\
\text { Basalt }\end{array}$ & $\begin{array}{l}\text { Phyric } \\
\text { Basalt }\end{array}$ & $\begin{array}{l}\text { Phyric } \\
\text { Basalt }\end{array}$ & Basalt & Basalt & Basalt & $\begin{array}{l}\text { Basaltic } \\
\text { Sand }\end{array}$ & $\begin{array}{l}\text { Glass of } \\
\text { Sand }\end{array}$ & Basalt & $\begin{array}{l}\text { Phyric } \\
\text { Basalt }\end{array}$ \\
\hline B2 & B2 & B2 & C & C & C & C & C & C & D \\
\hline 4 & 4 & 4 & 5 & 5 & 6 & 6 & 6 & 7 & 7 \\
\hline 49.88 & 49.67 & 49.39 & 49.08 & 48.83 & 49.42 & 48.96 & 49.15 & 49.17 & 49.60 \\
\hline 17.65 & 17.73 & 17.96 & 16.01 & 16.06 & 15.86 & 15.83 & 15.51 & 15.88 & 17.97 \\
\hline 9.06 & 8.59 & 8.49 & 10.58 & 10.45 & 10.33 & 10.86 & 10.27 & 10.13 & 8.23 \\
\hline 7.44 & 8.43 & 8.41 & 7.37 & 7.92 & 8.16 & 7.53 & 8.07 & 7.48 & 7.20 \\
\hline 12.70 & 12.60 & 12.54 & 11.74 & 11.63 & 11.26 & 11.58 & 11.19 & 11.66 & 12.14 \\
\hline 2.49 & 2.33 & $2: 36$ & 2.63 & 2.64 & 2.74 & 2.58 & 2.73 & 2.64 & 2.66 \\
\hline 0.21 & 0.18 & 0.18 & 0.35 & 0.28 & 0.21 & 0.25 & 0.18 & 0.34 & 0.24 \\
\hline 1.16 & 1.101 & 0.99 & 1.58 & 1.54 & 1.49 & 1.49 & 1.50 & 1.45 & 1.22 \\
\hline 0.11 & 0.11 & 0.09 & 0.17 & 0.16 & 0.15 & 0.16 & 0.15 & 0.16 & 0.12 \\
\hline 0.16 & 0.15 & 0.16 & 0.18 & 0.18 & 0.19 & 0.19 & 0.19 & 0.18 & 0.14 \\
\hline 100.86 & 100.80 & 100.48 & 99.69 & 99.69 & 99.81 & 99.43 & 98.94 & 99.09 & 99.52 \\
\hline-3.01 & -2.95 & -2.84 & -1.50 & -1.81 & -0.40 & -0.80 & +0.16 & -0.95 & -2.88 \\
\hline 1.08 & 0.95 & 1.30 & 0.76 & 0.77 & 0.53 & 0.46 & 0.76 & 0.67 & 1.38 \\
\hline 0.24 & 0.16 & 0.17 & 0.17 & 0.09 & 0.26 & 0.22 & 0.62 & 0.30 & 0.54 \\
\hline 0.62 & 0.66 & 0.66 & 0.58 & 0.60 & 0.61 & 0.58 & 0.61 & 0.59 & 0.63 \\
\hline 364.0 & 356.0 & 363.0 & 346.0 & 345.0 & 358.0 & 336.0 & 358.0 & 350.0 & 348.0 \\
\hline 139.0 & 157.0 & 154.0 & 140.0 & 133.0 & 139.0 & 128.0 & 137.0 & 122.0 & 155.0 \\
\hline 144.0 & 124.0 & 121.0 & 163.0 & 161.0 & 157.0 & 156.0 & 150.0 & 154.0 & 162.0 \\
\hline 73.0 & 68.0 & 63.0 & 106.0 & 109.0 & 115.0 & 80.0 & 103.0 & 108.0 & 85.0 \\
\hline
\end{tabular}

a Depth not normalized to recovery.

b $\mathrm{H}_{2} \mathrm{O}^{+}, \mathrm{H}_{2} \mathrm{O}^{-}, \mathrm{CO}_{2}$ analyses on a HP C-H-N Analyzer, Model 185B by Richard Myers, DSDP.

$\mathrm{C}_{2} \mathrm{H}^{+}$uncorrected for iron oxidation.

than the glass rinds and inner parts, perhaps because it generally appears to be the most vesicular zone of the pillow. On the other hand, the microlitic inner zones of the pillow offer more surface for reaction than the glassy rinds because of the grain boundaries.

\section{Chemical Composition of Basalts}

\section{Introduction}

Shipboard chemical analysis allows the establishment of a chemical stratigraphy for the drilled section and the com- 
parison of chemically defined magma types with lithologic and magnetic units. This on-line evaluation of drilling results aids both in the selection of additional nearby sites and in more rational sampling for onshore studies.

Analyses of 41 basaltic samples for eight major ( $\mathrm{Si}, \mathrm{Al}$, $\mathrm{Mg}, \mathrm{Fe}, \mathrm{K}, \mathrm{Ti}, \mathrm{Ca}, \mathrm{Mn})$ and four trace $(\mathrm{Cr}, \mathrm{Ni}, \mathrm{Sr}, \mathrm{Zr}$ ) elements were carried out on board (Table 6) by X-ray fluorescence methods. Loss on ignition was determined by heating for 1 hour at $1050^{\circ} \mathrm{C} ; \mathrm{H}_{2} \mathrm{O}^{+}$and $\mathrm{CO}_{2}$ were determined with a $\mathrm{CHN}$ analyzer. With one exception (Sample 396B-19-1, 4-6 cm, the freshest possible samples were chosen for analysis. $\mathrm{Na}_{2} \mathrm{O}$ and $\mathrm{P}_{2} \mathrm{O}_{5}$ were determined at $\mathrm{CNEXO}$ by atomic absorption methods.

Basalts were drilled for a total basement penetration of 255 meters. The section is dominated by pillow lavas in the interval 150 to 310 meters sub-bottom, with the single exception of a cooling unit, approximately 8 meters thick, of medium-grained basalt that makes up most of Core 15 . Recovery was very poor in the lower 90 meters of the cored interval which apparently consists principally of coarse basaltic "sand and gravel"' with either intercalated pillows or zones of coarser rubble (see section on lithology). Based upon shipboard chemistry, we have divided the pillow sequence into two main chemically defined magma groups corresponding to the upper sparsely phyric lavas and the lower porphyritic lavas; each of these major magma groups is divided into several subgroups (Figure 20). The chemical compositions of the basalt fragments in the lower sand and gravel sequence and the bulk sand composition are similar to the upper sparsely phyric lava group.

The chemistry of all rocks is typical of mid-ocean ridge basalts: $\mathrm{MgO}=7$ to 9 per cent, $\mathrm{Mg} /(\mathrm{Mg}+\mathrm{Fe})=0.57$ to $0.66, \mathrm{TiO}_{2}=0.9$ to 1.7 per cent, $\mathrm{CaO}=10.8$ to 12.8 per cent, $\mathrm{Al}_{2} \mathrm{O}_{3}=15$ to 18 per cent, total $\mathrm{Fe}$ as $\mathrm{FeO}=$ 7.4 to 10.4 per cent, $\mathrm{K}_{2} \mathrm{O}=0.1$ to 0.35 per cent, $\mathrm{Zr}=60$ to $130 \mathrm{ppm}, \mathrm{Sr}=110$ to $170 \mathrm{ppm}, \mathrm{Cr}=250$ to $370 \mathrm{ppm}$, and $\mathrm{Ni}=110$ to $160 \mathrm{ppm}$.

The chemical compositions of these basalts are relatively evolved in comparison with the most primitive basalts recovered from the Mid-Atlantic Ridge. This probably indicates that the magmas have been derived from more primitive mantle-derived melts through fractional crystallization, although rocks of more primitive composition have not been recovered from this portion of the Mid-Atlantic Ridge (20 to $22^{\circ} \mathrm{N}$ ). If this lack of more primitive compositions is not an artifact of sampling, it may result either from tectonic conditions that do not allow more primitive magmas to reach the near-sea-floor environment or from different primary magmas reflecting mantle heterogeneity and/or different conditions of partial melting along this segment of the MidAtlantic Ridge.

The chemical data are tabulated (Tables 6 and 7) and are discussed below under the following topics: methods, alteration, stratigraphy, petrology, and regional comparison.

\section{Methods}

The analytical procedure used for shipboard analyses may be divided into two stages:

1) Sample preparation utilized the following equipment: motor-driven agate mortar and pestle, RETSCH K.G. type RMC; electromicrobalance CAHN model G series 1500; electric furnace ERSEM, $0^{\circ}$ to $1300^{\circ} \mathrm{C}$; OPR crucible composed of an alloy of gold, platinum, and rhodium, allowing an easy unmolding of the glass disc; hydraulic laboratory press CARVER model " $\mathrm{C}$ '.

2) X-ray fractionation (XRF) analyses carried out in the CNEXO van, which has been utilized with success during other oceanographic cruises (Gibraco CNEXO 1972; Biogas CNEXO 1974; Leg 37 DSDP, 1974; and DSDP Leg 45, 1976). The Siemens XRF equipment consisted of high power supply Kristalloflex 4, manual VRS analyzer, transistorized counting rack, digital printer D44 for data output.

The cooling system consisted of a fresh water circuit cooled by seawater through heat exchangers. A Moineau electro-pump pulsed the fresh water into the circuit. High seawater temperatures $\left(>25^{\circ} \mathrm{C}\right)$ prevented the utilization of the high power supply to its maximum efficiency.

Sample preparation techniques are summarized in a flow diagram (Figure 21). Glass discs were used for major element analyses, and pressed powder pellets for trace element analyses. In addition to the elements analyzed on Leg 45, Mn was also measured on the pellets used previously for trace element analysis. Measurements of Mn concentrations in powder pellets were performed and a small matrix correction was applied (Figure 22). The position for measurement of Mn backgrounds was chosen with care to avoid the influence of the $\mathrm{Cr}-\mathrm{K}_{\beta}$ peak. $\mathrm{MnO}$ standardizations were within 3 per cent of the values listed in Flanagan (1972). A comparison of shipboard $\mathrm{MnO}$ values and the recommended standard values is given below.

\begin{tabular}{lcll} 
Recommended Values & \multicolumn{2}{c}{ Computed } & Shipboard Values \\
BR & 0.200 & 0.194 & basalt \\
BCR1 & 0.180 & 0.180 & basalt \\
DRN & 0.210 & 0.215 & diorite \\
PCC1 & 0.12 & 0.114 & peridotite \\
DTS1 & 0.11 & 0.116 & dunite \\
AGV1 & 0.097 & 0.098 & andesite \\
GSP1 & 0.042 & 0.041 & granodiorite
\end{tabular}

Eight samples were fused and analyzed in duplicate. The precision of the shipboard analyses, as indicated by these replicate analyses, is within \pm 2 per cent with $\mathrm{Al}$ showing the largest variation. The maximum error $(2 \sigma)$ resulting from counting statistics for the major elements is as follows: $\mathrm{MgO} \pm 2.0$ per cent, $\mathrm{SiO}_{2} \pm 1.0$ per cent, $\mathrm{Al}_{2} \mathrm{O}_{3} \pm 1.0$ per cent, $\mathrm{K}_{2} \mathrm{O} \pm 1.0$ per cent, $\mathrm{Fe}_{2} \mathrm{O}_{3} \pm 0.7$ per cent, and $\mathrm{CaO}$ \pm 0.5 per cent.

The $\mathrm{H}_{2} \mathrm{O}^{+}$and $\mathrm{CO}_{2}$ contents of all chemically analyzed basalts were determined with a Hewlett-Packard Model 185B Carbon-Hydrogen-Nitrogen Analyzer. The method required 20 to $25 \mathrm{mg}$ of rock powder, which were placed in a decomposition furnace. Samples were automatically heated to $1050^{\circ} \mathrm{C}$ and, after 50 seconds, volatiles were allowed to enter the gas chromatograph. At the end of the column, they entered a thermal conductivity detector block that electrically measures concentrations.

Samples and standards were processed identically with the exception of powdering. Both were weighed in aluminum boats ( 20 to $25 \mathrm{mg}$ ) and dried for a minimum of 12 hours at $110^{\circ} \mathrm{C}$ before analysis.

\section{Chemical Alteration}

The chemical composition of ocean floor basalts may be changed appreciably by interaction with seawater. It is 


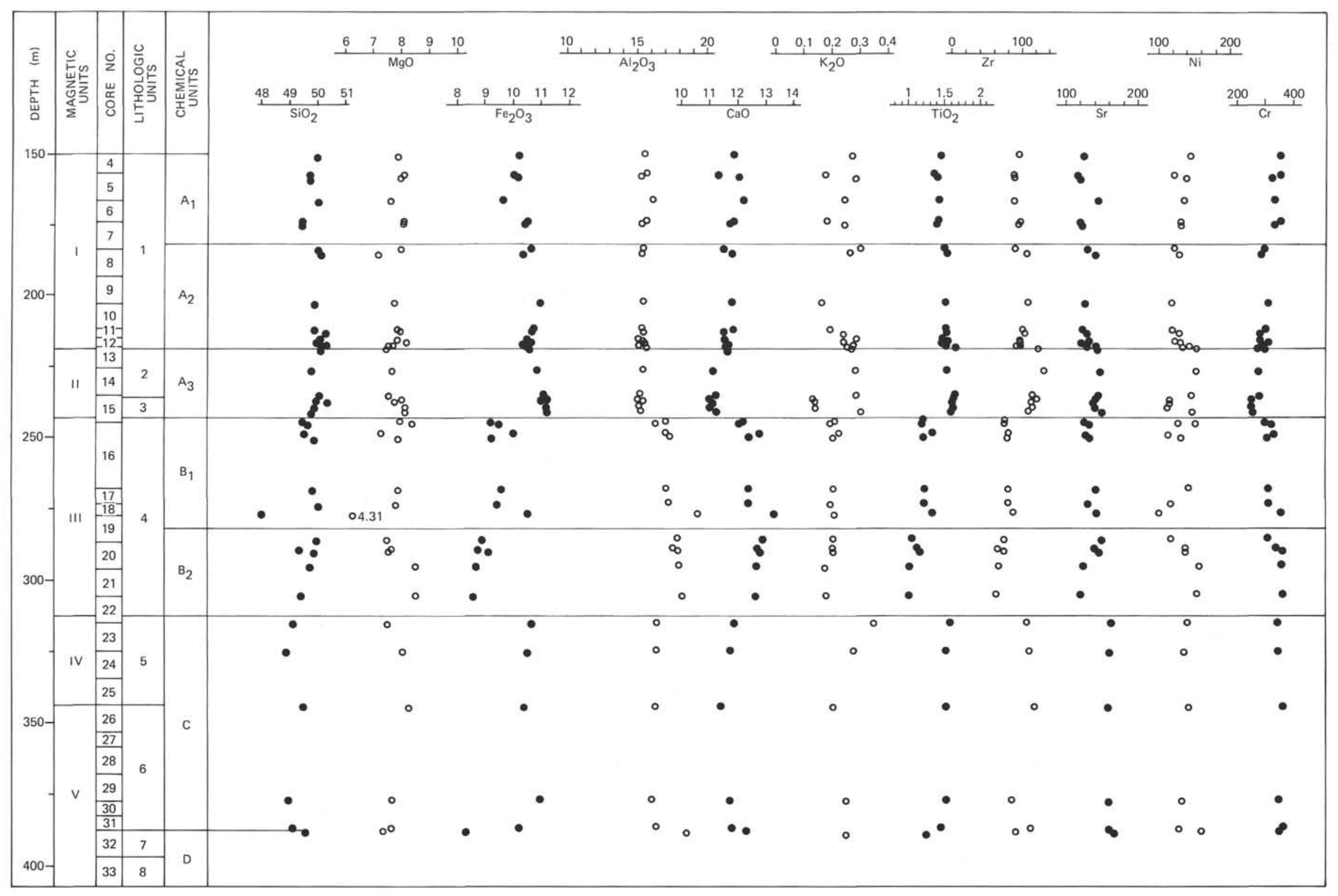

Figure 20. Stratigraphic column of Hole 396 B with bulk analyses plotted versus depth. 
TABLE 7

Average Compositions of Magmatic Units, Hole 396B

\begin{tabular}{|c|c|c|c|c|c|c|}
\hline Chemical Unit & A1 & A2 & A3 & B1 & B2 & $\mathrm{C}$ \\
\hline No. of Analyses & 6 & 9 & 8 & 6 & 5 & 6 \\
\hline $\begin{array}{l}\text { Major Elements } \\
(\%)\end{array}$ & & & & & & \\
\hline $\mathrm{SiO}_{2}$ & $49.69 \pm 0.25$ & $50.03 \pm 0.17$ & $49.94 \pm 0.23$ & $49.67 \pm 0.20$ & $49.63 \pm 0.29$ & $49.10 \pm 0.20$ \\
\hline $\mathrm{Al}_{2} \mathrm{O}_{3}$ & $15.59 \pm 0.32$ & $15.29 \pm 0.10$ & $15.19 \pm 0.19$ & $16.91 \pm 0.13$ & $17.66 \pm 0.24$ & $15.86 \pm 0.19$ \\
\hline $\mathrm{Fe}_{2} \mathrm{O}_{3}$ & $10.15 \pm 0.32$ & $10.53 \pm 0.22$ & $11.00 \pm 0.24$ & $9.45 \pm 0.29$ & $8.73 \pm 0.22$ & $10.44 \pm 0.26$ \\
\hline $\mathrm{MgO}$ & $7.93 \pm 0.15$ & $7.72 \pm 0.27$ & $7.75 \pm 0.36$ & $7.78 \pm 0.36$ & $7.84 \pm 0.53$ & $7.76 \pm 0.34$ \\
\hline $\mathrm{CaO}$ & $11.83 \pm 0.32$ & $11.66 \pm 0.13$ & $11.12 \pm 0.11$ & $12.34 \pm 0.22$ & $12.66 \pm 0.10$ & $11.51 \pm 0.23$ \\
\hline $\mathrm{Na}_{2} \mathrm{O}$ & $2.60 \pm 0.06$ & $2.65 \pm 0.09$ & $2.79 \pm 0.09$ & $2.45 \pm 0.12$ & $2.43 \pm 0.08$ & $2.66 \pm 0.06$ \\
\hline $\mathrm{K}_{2} \mathrm{O}$ & $0.24 \pm 0.05$ & $0.25 \pm 0.04$ & $0.23 \pm 0.08$ & $0.22 \pm 0.01$ & $0.20 \pm 0.02$ & $0.27 \pm 0.07$ \\
\hline $\mathrm{TiO}_{2}$ & $1.41 \pm 0.03$ & $1.53 \pm 0.02$ & $1.64 \pm 0.02$ & $1.23 \pm 0.05$ & $1.06 \pm 0.07$ & $1.51 \pm 0.05$ \\
\hline $\mathrm{P}_{2} \mathrm{O}_{5}$ & $1.14 \pm 0.01$ & $0.15 \pm 0.01$ & $0.16 \pm 0.01$ & $0.12 \pm 0.01$ & $0.10 \pm 0.01$ & $0.16 \pm 0.01$ \\
\hline \multicolumn{7}{|l|}{$\begin{array}{l}\text { Trace Elements } \\
\text { (ppm) }\end{array}$} \\
\hline $\mathrm{Cr}$ & $347 \pm 12$ & $305 \pm 11$ & $277 \pm 15$ & $332 \pm 11$ & $351 \pm 16$ & $349 \pm 8$ \\
\hline $\mathrm{Ni}$ & $136 \pm 8$ & $132 \pm 7$ & $138 \pm 19$ & $133 \pm 14$ & $142 \pm 15$ & $133 \pm 7$ \\
\hline $\mathrm{Sr}$ & $128 \pm 11$ & $139 \pm 8$ & $145 \pm 5$ & $133 \pm 5$ & $136 \pm 12$ & $157 \pm 5$ \\
\hline $\mathrm{Zr}$ & $94 \pm 4$ & $101 \pm 6$ & $120 \pm 6$ & $80 \pm 2$ & $69 \pm 5$ & $104 \pm 12$ \\
\hline
\end{tabular}

therefore important to evaluate alteration effects prior to the interpretation of the chemical data in terms of magmatic processes. Which elements are preferentially lost, gained, or redistributed is a function of the specific alteration reactions involved. The most important types of alteration in Hole 396B basalts are: (1) Iddingsitization of olivine. (2) Carbonates, zeolites, smectite, and $\mathrm{Mn}$ oxides filling vesicles and fractures. (3) Replacement of glassy mesostasis by smectite.

The elements $\mathrm{Sr}$ and $\mathrm{K}$ show anomalous scatter in $\mathrm{MgO}$ variation diagrams (Figure 23) and poor correlations with other elements. In contrast, $\mathrm{Sr}$ and (to a lesser extent) $\mathrm{K}$ are positively correlated with loss on ignition (L.O.I.), suggesting that these elements increase with increased degree of alteration. The degree of correlation varies among the units; e.g., the increase in $\mathrm{Sr}$ with L.O.I. in Subunit $\mathrm{B}_{1}$ is quite pronounced, while none exists in $\mathrm{B}_{2}$ (Figure 24). The correlation of increases in $\mathrm{K}_{2} \mathrm{O}$ and L.O.I. in Subunits A1 to A3 contrasts with an apparent slight decrease in $\mathrm{B}_{1}$ and $\mathrm{B}_{2}$. Within Core 15 , basalts show a significant range in L.O.I. without any change in $\mathrm{K}_{2} \mathrm{O}$ and $\mathrm{Sr}$. In addition, the absolute concentrations of these elements (particularly $\mathrm{K}_{2} \mathrm{O}$ ) are relatively low compared to the upper portion of A3 (Cores 13, 14). This relationship is much less distinct for L.O.I. versus $\mathrm{MgO}$. However, it is clear that $\mathrm{Mg}$ may be lost drastically from basalts in which olivine is strongly replaced, e.g., analysis of Sample 396B-19-1, 4-6 cm (4.3 wt. \% MgO versus 7.5 to 8.5 predicted from its general chemical composition). Based on the present data, we cannot establish the presence of smaller progressive changes in $\mathrm{Mg}$ content. A correlation also exists between the amount of smectite in a rock and its $\mathrm{K}$ content, and between $\mathrm{CO}_{2}$ content and abundance of carbonate as seen in thin section and hand specimen. Although the effects of deuteric alteration were not fully evaluated, the cooling unit recovered in Core 15 shows

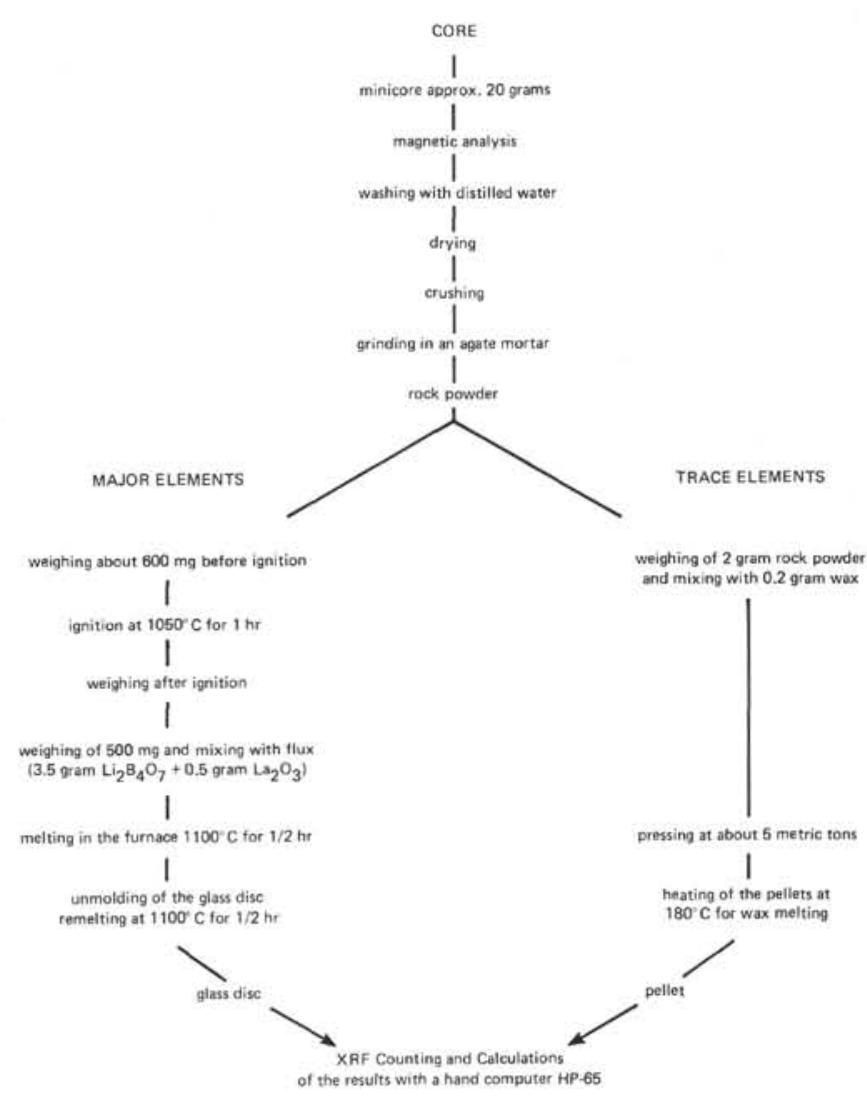

Figure 21. Flow diagram of the analytical method for chemical analyses.

major variations in L.O.I. and only minor changes in $\mathrm{Sr}$ and $\mathrm{K}$, suggesting that this relatively thick cooling unit was isolated from major seawater alteration. 


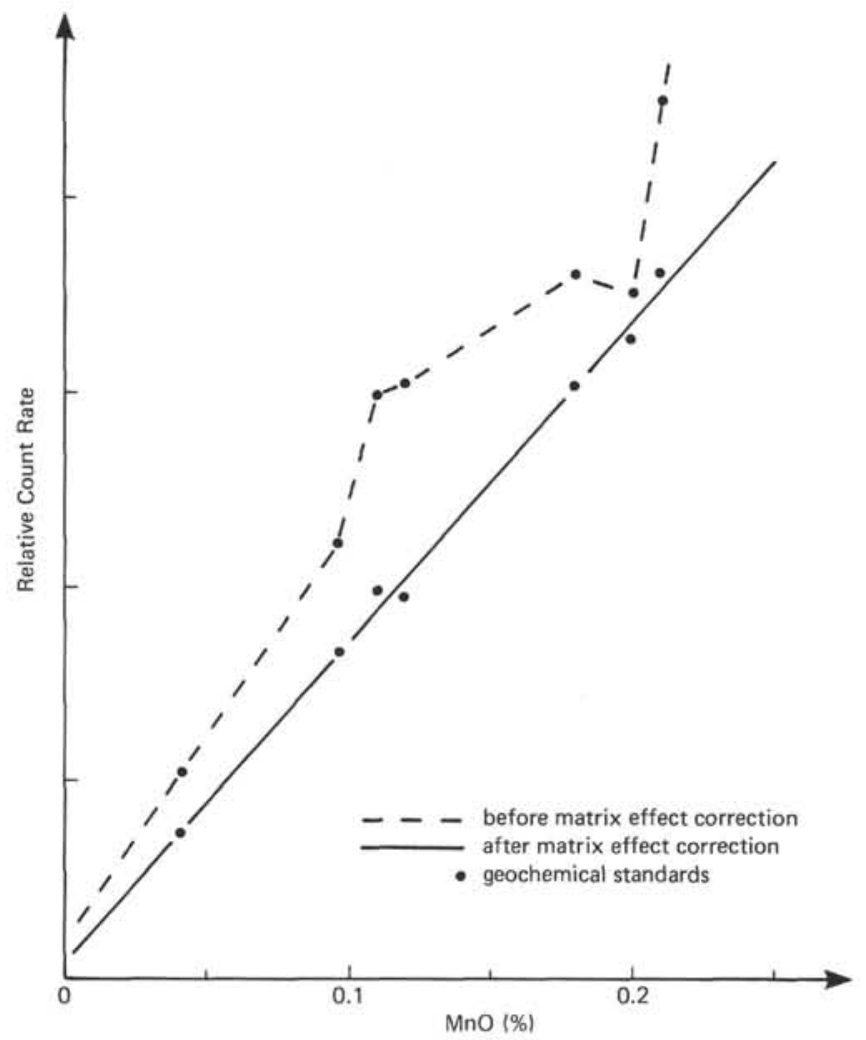

Figure 22. MnO standardization lines.

\section{Chemical Stratigraphy}

The chemical units are distinguished by a certain chemical coherence, $\mathrm{Ti}$ being the most useful discriminate. Four units (A, B, C, D) were distinguished; the two major units were subdivided into $\mathrm{A} 1, \mathrm{~A} 2, \mathrm{~A} 3, \mathrm{~B} 1$, and $\mathrm{B} 2$.

Unit A comprises the upper 95 meters (150 to $245 \mathrm{~m}$, Cores 4 to 15 ) and consists of very sparsely olivineplagioclase phyric pillow basalts (Analyses 1 to 16, Tables 6 and 7, Figures 20 and 23).

Unit B comprises the next 64 meters (245 to $309 \mathrm{~m}$, Cores 16 to 23 ), and consists of abundantly phyric (15 to $25 \%$ of plagioclase-olivine-spinel phenocrysts) pillow basalt (11 analyses).

Unit $C$ occurs within the next lower 80 meters ( 310 to 385 $\mathrm{m}$, Cores 23 to 32 ) and is made mostly of very sparsely to moderately phyric olivine-plagioclase phyric basalt. However, recovery was extremely low $(<1 \%)$ and most of the material in that interval is basaltic "sand" (6 analyses).

Unit D is composed of a single analysis of porphyritic basalt from the base of the section (Core 32) in which the basalt varies from sparsely to moderately phyric plagioclase-olivine basalt.

While the boundaries between the major units generally correspond with magnetic and gross lithologic boundaries, those between the subunits are marked only by abrupt or transitional changes in chemistry.

\section{Chemical Variation and Petrology}

The following discussion of petrochemical relationships among the various magma groups found in Hole 396B is based upon elements that: (1) are least likely to be redistri- buted during alteration, (2) show high analytical precision, and (3) are strongly partitioned into either the melt or a crystalline phase.

The elements most useful in defining chemical units are $\mathrm{Fe}$ and the incompatible elements $\mathrm{Zr}$ and $\mathrm{Ti}$. $\mathrm{Ni}$ and $\mathrm{Cr}$ are also useful because of their strong partitioning into olivine and spinel, respectively, although the role of $\mathrm{Cr}$ is somewhat complicated by its large affinity for clinopyroxene. The usefulness of $\mathrm{Sr}$ as an indicator of plagioclase fractionation is somewhat compromised by its mobility during alteration (Figures 23 and 24).

The total chemical variation within the basalts sampled is relatively small; however, the step-like, chemical changes between units and the relative chemical homogeneity that exist within many of the groups indicate that the chemically defined units represent discrete magma batches. Chemical variation within the individual subunits of Unit A are somewhat more difficult to explain. The order of apparent fractionation is from $\mathrm{A} 1$ to $\mathrm{A} 3$, exactly inverse to the eruption sequence, making a straightforward relationship seem unlikely. In addition, the intra-unit chemical variation, particularly of $\mathrm{Ca}$ and $\mathrm{Al}$, cannot be explained by fractionation of plagioclase, olivine, and spinel, i.e., the observed phenocryst phases. The subunits might be related through pyroxene fractionation, but this is highly uncertain in light of the absence of clinopyroxene phenocrysts. On the basis of the preliminary shipboard analyses, it appears possible that Subunit B1 might be derivable from Subunit B2 through fractionation of plagioclase; however, this possibility and the possibility that magmas similar to group A might be derived from magmas similar to Unit B must await more detailed analyses and more sophisticated calculations.

The general depletion in $\mathrm{Ni}$ and $\mathrm{Cr}$, coupled with the relative enrichment in $\mathrm{Zr}, \mathrm{Ti}$, and $\mathrm{Fe}$ relative to $\mathrm{Mg}$ when compared to the more primitive oceanic basalts recovered from the FAMOUS area (Bryan and Moore, 1977) and by DSDP Leg 2 (Frey et al., 1974) and Leg 37 all indicate that the Hole 396B basalts represent magmas that underwent fractionation prior to eruption. The type of variation exhibited by the subunits of magma Unit A indicates the generation of a sequence of batches of similar but apparently unrelated magmas. On the other hand, the subgroups of magma in Unit B, together with the samples recovered from Hole 396 (Leg 45), may represent a genetically related series of magmas linked through near-surface fractionation of plagioclase.

The higher $\mathrm{Sr}$ concentration in chemical Unit $\mathrm{C}$, relative to Units A and B, is the distinct trace element characteristics of this unit.

\section{Regional Comparison}

Rocks recovered from Hole 396 are generally similar to those representing magma Unit B from Hole 396B; however, the Hole 396 samples are lower in $\mathrm{Ca}$ and $\mathrm{Al}$ and higher in $\mathrm{Fe}$ and $\mathrm{Ti}$. The overall chemical variation is consistent with the fractionation series B2 and B1 of Hole 396B and the basalts of Hole 396. Basalts from Hole 396B are compositionally similar to those from Site 395, however, the magma types are clearly not identical.

Comparison of samples from Sites 395 and 396, dredge hauls from $22^{\circ} \mathrm{N}$ (Miyashiro et al., 1971), and analyses of glasses from the FAMOUS area indicates that the samples 


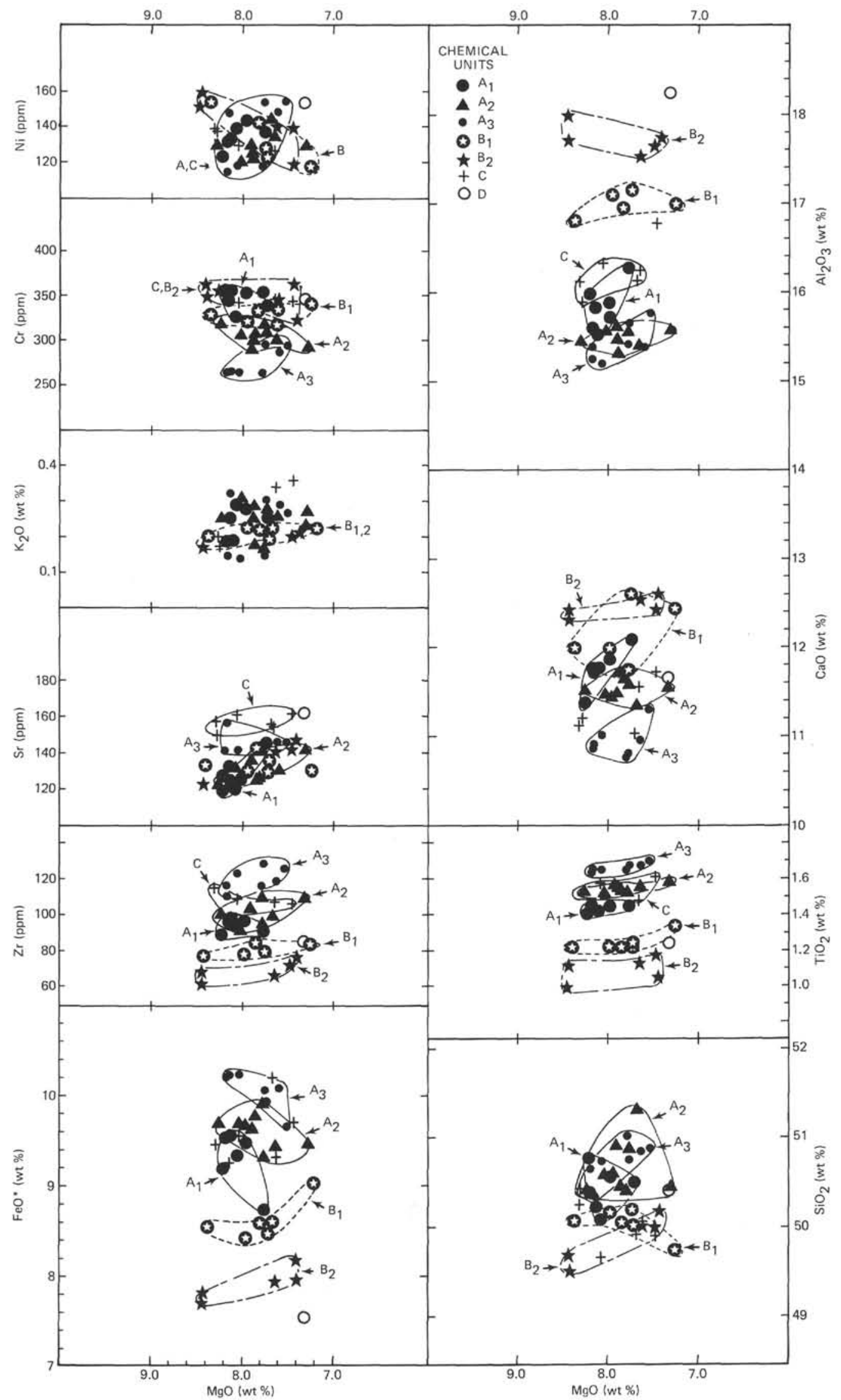

Figure 23. $\mathrm{MgO}$ variation diagrams for Hole $396 \mathrm{~B}$ basalts. 


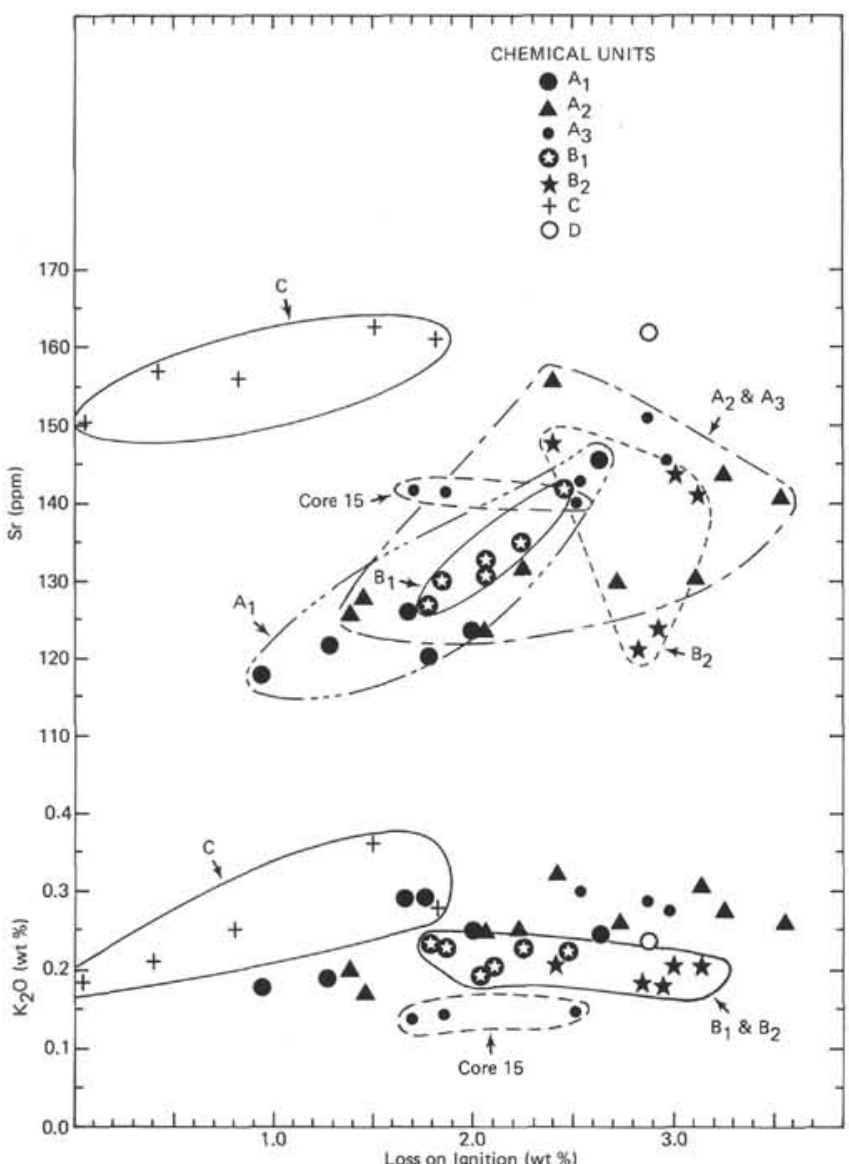

Figure 24. $\mathrm{K}_{2} \mathrm{O}$ and $\mathrm{Sr}$ versus loss om ignition for Hole $396 \mathrm{~B}$ basalts.

from 20 to $22^{\circ} \mathrm{N}$ are generally similar and are systematically more "evolved" than the more primitive samples from the FAMOUS area. This regional pattern, if not a result of sampling bias, may have important implications for the development of this portion of the oceanic crust. This pattern may indicate tectonic conditions that restrict or slow the rise of magma beneath the ridge and thus prevent relatively unfractionated magmas from reaching the near sea-bottom environment. More fundamentally, this regional pattern may reflect different primary magma compositions resulting from upper mantle heterogeneity or, possibly, different conditions of partial melting.

\section{PHYSICAL PROPERTIES}

\section{Magnetics}

\section{Instruments and Methods}

The instruments and methods employed for this site were the same as on Leg 45. The remanent magnetization of the rocks was measured with a Schoenstedt Digital Spinnel Magnetometer (Model DSM-1). Attenuating field demagnetization in magnetic fields up to 1000 Oe was obtained by a Schoenstedt A.C. Geophysical Specimen and Demagnetizer (Model GSD-1). Because this model is a one-component demagnetizer, the specimens had to be demagnetized in all three directions successively at each step of demagnetization. Both instruments worked very satisfactorily. Step-wise demagnetization of the specimens was conducted to measure the stability of remanent magnetization and to determine the "stable direction" of magnetization. The natural remanent magnetization (NRM) of basalts normally is of a composite nature; it consists of the original thermoremanent magnetization acquired during cooling after eruption and also of other magnetization components acquired subsequently, like viscous magnetization and chemical magnetization. Under normal circumstances, the step-wise demagnetization will remove these secondary, normally less stable components of magnetization, and the more stable original thermoremanent magnetization can then be determined.

The procedure of the determination of stable magnetization direction is illustrated in Figure 25. The stable direction is characterized by a certain "plateau" in the inclination (declination) versus A.C. demagnetizing field plot. In few cases, the stable direction could not be determined with certainty (e.g., Figure 26); these values are marked in the compilation of shipboard data (Table 8) with a question mark.

The rocks measured during this leg were oriented only with respect to vertical. Therefore, only the inclination of magnetization direction can be given in absolute values, with the declination representing only a relative value.
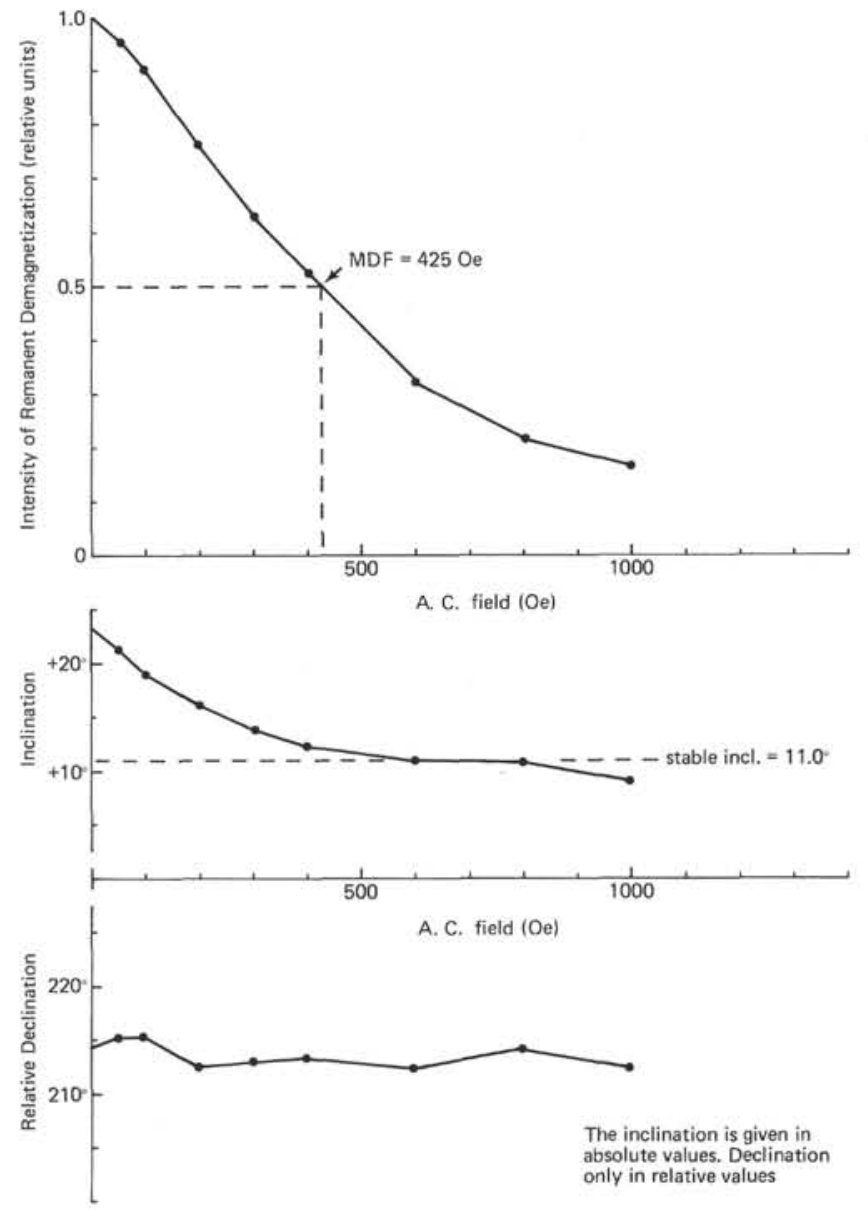

Figure 25. Typical results of demagnetization of basalt showing stable inclination, Sample 396B-11-2-1, 5-7 cm. 

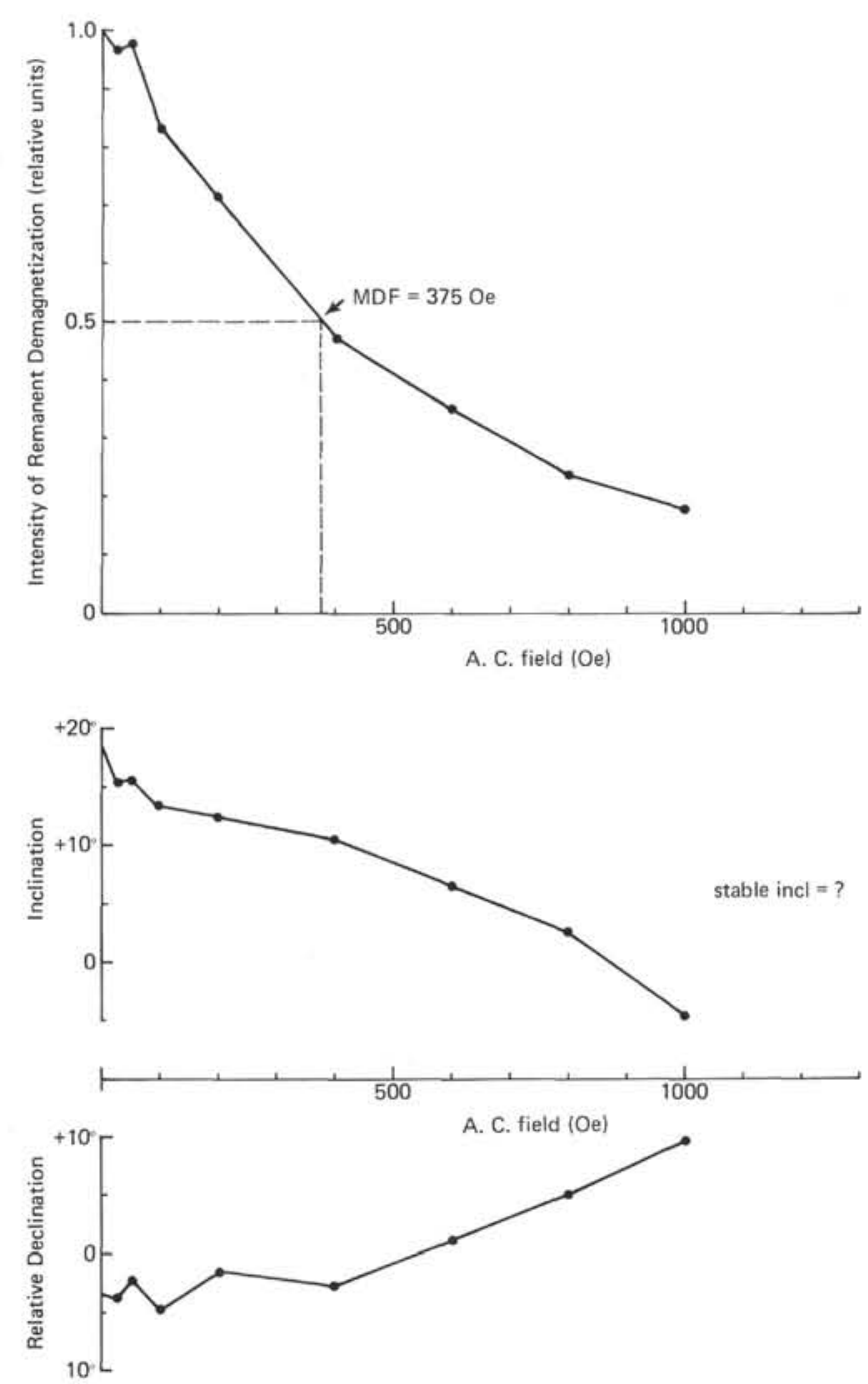

Figure 26. Typical results of demagnetization of basalt with no stable inclination, Sample 396B-13-2-5A, $49-51 \mathrm{~cm}$.

The stability of remanent magnetization is given here as the median destructive field (MDF) which is the A.C. (demagnetizing) field necessary to erase half of the original intensity of magnetization.

\section{Results}

The results of the magnetic shipboard measurements are summarized in Table 8 . The following parameters are listed there:

1) Original NRM, inclination, and intensity; these are the original inclination and intensity values prior to any demagnetization.

2) Stable inclination; these values are obtained after A.C. field demagnetization as explained above (see also Figure 25).

3) A.C. field necessary to obtain the stable inclination; in the example of Figure 25, it is 600 Oe.

4) Median destructive field (MDF); this is the A.C. field necessary to erase half of the original intensity of magnetization, and is a measure of stability of remanence.
A downhole plot of these parameters, including the results of the shore-based measurements, is given by Peterson (this volume). In this figure, the theoretical central dipole value for the inclination of the earth's magnetic field at the latitude of drilling has been included for comparison, i.e., $+40.3^{\circ}$.

The most significant results are the consistency of the stable inclination values within certain units, the occurrence of different polarity groups, and the difference between measured inclinations and the theoretical dipole value.

The different polarity groups define the following magnetic units:

Unit I from Section 4-1 (top of the basalts) to Sample $14-1,81-83 \mathrm{~cm}$. The mean inclination is $+20.8^{\circ}$. It should be mentioned that the sediment at Sample 13-2, \#2A has an inclination of $-35^{\circ}$ which differs significantly from the mean value $+20.8^{\circ}$, although it is well within Unit 1 .

Unit II from Sample 14-1, $81-83 \mathrm{~cm}$ to the bottom of Core 15 . The mean inclination is $-69.3^{\circ}$. Unit II is much thinner compared to the other magnetic units.

Unit III extends from Section 16-1 to the bottom of core 22 . The mean inclination is $-6.0^{\circ}$, with very little scatter around this value.

Unit IV begins with Section 23-1 and extends down to Sample 26-1, \# 1. The mean inclination is $-27.2^{\circ}$; however it is magnetically badly defined as there were too few oriented samples available for measurement.

The intensities of remanent magnetization (original intensity values prior to demagnetization) of Units I and III are distinctly different. The mean value of $0.85 \times 10^{-3}$ $\mathrm{emu} / \mathrm{cm}^{3}$ for Unit I is much below the average of ocean floor basalts in general, whereas the mean value of $2.70 \times 10^{-3}$ $\mathrm{emu} / \mathrm{cm}^{3}$ of Unit III comes close to the general average. This difference is probably due to a higher degree of low temperature oxidation of the rocks from Unit I.

The mean values of stable inclination and original NRM intensity of the different magnetic units are summarized in Table 9. (These mean values also contain the shore-based measurements given by Peterson, this volume.)

\section{Drilling Remanence}

In many of the Leg 45 rocks, we observed a vertical remanent magnetization component pointing downwards. This component could be erased by A.C. demagnetization of a few hundred oe and has been interpreted by the Leg 45 scientists as drilling remanence, induced by the magnetic field of the drill bit. No such drilling remanence has been observed in the Leg 46 rocks. This may be due to the high magnetization stability of the rocks encountered here.

\section{Petrography and Chemistry}

The boundary of magnetic Units I and II is reflected neither in petrography nor in geochemistry; however, there is indication of an anomaly in the logging downhole plot (Kirkpatrick, this volume). Boundary II-III is reflected in both chemistry (chemical Units $\mathrm{A}_{3} / \mathrm{B}_{1}$ ) and petrography (petrographic Units 3/4). Boundary III-IV is also reflected in both chemistry $\left(B_{2} / C\right)$ and petrography $(4 / 5)$. The lower boundary of IV coincides with the petrographic boundary 5-6. Table 10 summarizes these relationships. 
TABLE 8

Rock Magnetism Data for Hole 396B

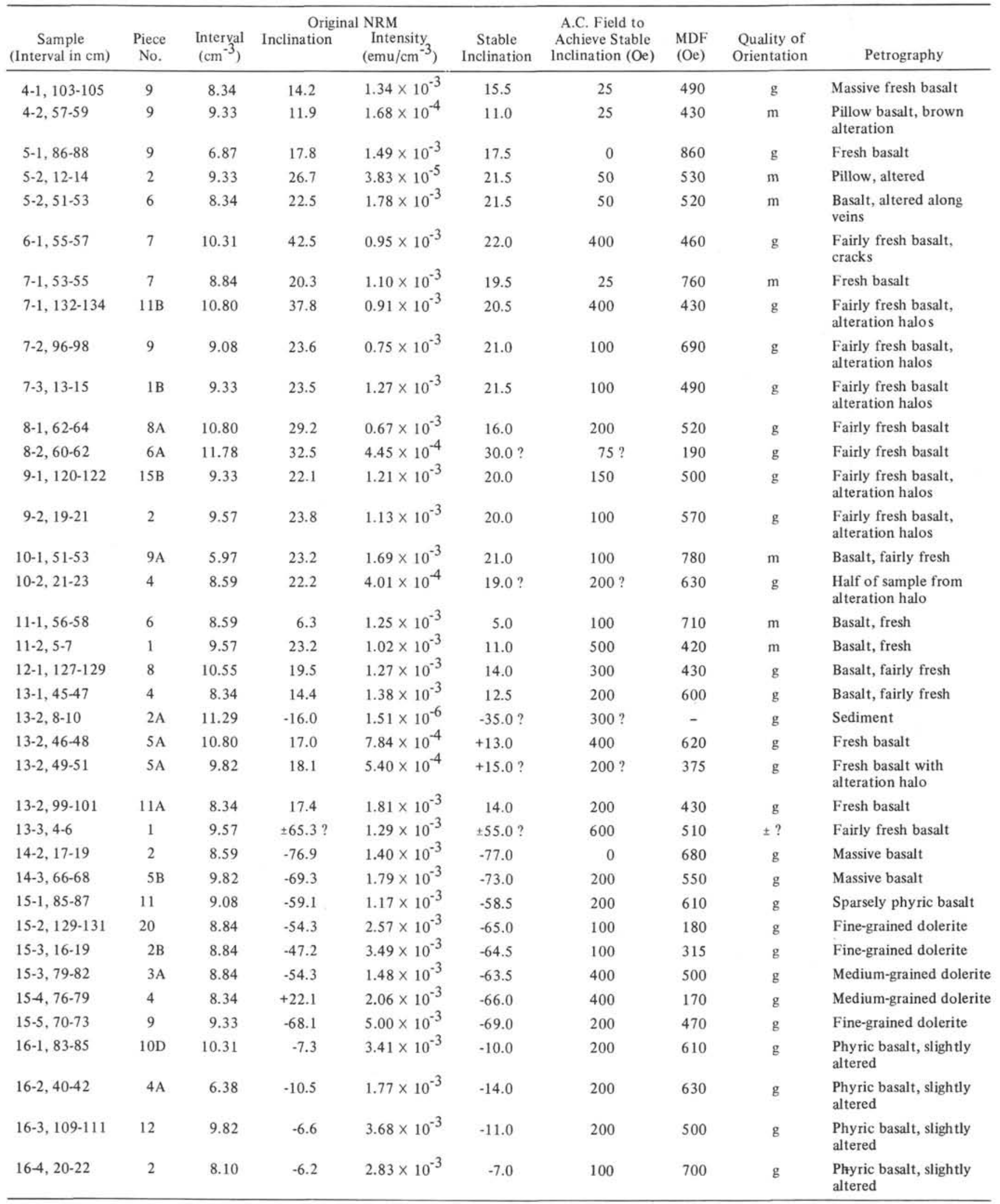


TABLE 8 - Continued

\begin{tabular}{|c|c|c|c|c|c|c|c|c|c|}
\hline $\begin{array}{c}\text { Sample } \\
\text { (Interval in } \mathrm{cm} \text { ) }\end{array}$ & $\begin{array}{l}\text { Piece } \\
\text { No. }\end{array}$ & $\begin{array}{l}\text { Interval } \\
\left(\mathrm{cm}^{-3}\right)\end{array}$ & $\begin{array}{l}\text { Origir } \\
\text { Inclination }\end{array}$ & $\begin{array}{l}\text { NRM } \\
\text { Intensity } \\
\left(\mathrm{emu} / \mathrm{cm}^{-3}\right)\end{array}$ & $\begin{array}{c}\text { Stable } \\
\text { Inclination }\end{array}$ & $\begin{array}{l}\text { A.C. Field to } \\
\text { Achieve Stable } \\
\text { Inclination (Oe) }\end{array}$ & $\begin{array}{l}\text { MDF } \\
\text { (Oe) }\end{array}$ & $\begin{array}{l}\text { Quality of } \\
\text { Orientation }\end{array}$ & Petrography \\
\hline $16-5,96-98$ & 11 & 9.57 & -10.6 & $2.78 \times 10^{-3}$ & -10.5 & 100 & 600 & g & $\begin{array}{l}\text { Phyric basalt, slightly } \\
\text { altered }\end{array}$ \\
\hline $17-1,132-134$ & $11 \mathrm{~B}$ & 8.59 & 2.6 & $2.11 \times 10^{-3}$ & -7.0 & 200 & 620 & $\mathrm{~g}$ & $\begin{array}{l}\text { Phyric basalt, slightly } \\
\text { altered }\end{array}$ \\
\hline $17-3,33-35$ & $2 \mathrm{~B}$ & 9.33 & -3.1 & $2.78 \times 10^{-3}$ & -7.5 & 200 & 460 & $\mathrm{~g}$ & $\begin{array}{l}\text { Phyric basalt, slightly } \\
\text { altered }\end{array}$ \\
\hline $18-1,117-119$ & $7 \mathrm{D}$ & 8.84 & +4.7 & $3.38 \times 10^{-3}$ & 0 & 200 & 600 & $\mathrm{~g}$ & Phyric basalt, fresh \\
\hline $19-1,4-6$ & 1 & 9.33 & -14.9 & $5.02 \times 10^{-3}$ & $-16.5 ?$ & $100 ?$ & 690 & g & $\begin{array}{l}\text { Phyric basalt, slightly } \\
\text { altered }\end{array}$ \\
\hline $20-1,53-55$ & $4 B$ & 9.08 & -9.4 & $3.51 \times 10^{-3}$ & -10.5 & 100 & 585 & g & Phyric basalt, fresh \\
\hline $20-2,51-53$ & $5 \mathrm{~A}$ & 9.82 & +0.1 & $3.15 \times 10^{-3}$ & -0.5 & 50 & 590 & $g$ & $\begin{array}{l}\text { Internal part of pillow, } \\
\text { fresh }\end{array}$ \\
\hline $20-3,33-35$ & 4 & 10.80 & 2.4 & $2.67 \times 10^{-3}$ & -5.0 & 300 & 640 & $\mathrm{~g}$ & $\begin{array}{l}\text { Phyric basalt, slightly } \\
\text { altered }\end{array}$ \\
\hline $20-4,71-73$ & $11 \mathrm{~A}$ & 8.59 & -2.2 & $2.19 \times 10^{-3}$ & -1.5 & $200 ?$ & 720 & $\mathrm{~g}$ & $\begin{array}{l}\text { Phyric basalt, slightly } \\
\text { altered }\end{array}$ \\
\hline $20-5,16-18$ & 2 & 8.84 & -7.0 & $2.75 \times 10^{-3}$ & -7.5 & 100 & 610 & $\mathrm{~g}$ & $\begin{array}{l}\text { Phyric basalt, } \\
\text { moderately altered }\end{array}$ \\
\hline $21-1,107-109$ & $12 \mathrm{~A}$ & 11.29 & -4.7 & $2.61 \times 10^{-3}$ & -8.5 & 200 & 620 & $\mathrm{~g}$ & $\begin{array}{l}\text { Phyric basalt, } \\
\text { relatively fresh }\end{array}$ \\
\hline $21-2,24-26$ & 2 & 9.33 & -3.8 & $3.79 \times 10^{-3}$ & -5.0 & 200 & 610 & $\mathrm{~g}$ & $\begin{array}{l}\text { Phyric basalt, } \\
\text { relatively fresh }\end{array}$ \\
\hline $22-1,93-95$ & 11 & 7.85 & -1.9 & $3.78 \times 10^{-3}$ & -2.5 & 100 & 760 & $\mathrm{~g}$ & Phyric basalt, fresh \\
\hline $22-2,34-36$ & $7 \mathrm{D}$ & 7.85 & +5.4 & $10.09 \times 10^{-3}$ & -4.5 & 200 & 140 & $\mathrm{~g}$ & Phyric basalt, fresh \\
\hline $22-3,50-52$ & $3 \mathrm{~A}$ & 8.10 & -3.2 & $3.16 \times 10^{-3}$ & -5.0 & 200 & 750 & $\mathrm{~g}$ & Phyric basalt, fresh \\
\hline $23-1,80-82$ & $12 \mathrm{~B}$ & 8.34 & +55.4 & $2.27 \times 10^{-3}$ & +54.0 & 200 & 710 & $\mathrm{~g}$ & Sparsely phyric basalt \\
\hline $24-1,94-96$ & $15 \mathrm{~A}$ & 8.84 & +17.2 & $2.17 \times 10^{-3}$ & +16.0 & 100 & 685 & $\mathrm{~m}$ & Sparsely phyric basalt \\
\hline $28-1,10-12$ & 2 & 7.85 & -10.0 & $2.46 \times 10^{-3}$ & $-6.5 ?$ & $100 ?$ & 220 & $\mathrm{~m}$ & Altered basalt \\
\hline $32-1,69-71$ & 10 & 7.61 & +45.0 & $2.59 \times 10^{-3}$ & +43.0 & 200 & 470 & $\mathrm{~g}$ & Fresh phyric basalt \\
\hline $32-1,85-87$ & 12 & 11.54 & -11.0 & $3.15 \times 10^{-3}$ & $-14.5(-20.5)$ & 200 & 600 & p & Fresh phyric basalt \\
\hline $26-1,3-5$ & 1 & 4.56 & +20.7 & $1.10 \times 10^{-3}$ & +22.0 & 200 & 880 & $\mathrm{p}$ & Fresh pillow basalt \\
\hline
\end{tabular}

Note: $\mathrm{g}=$ good,

$\mathrm{m}=$ medium $\mathrm{p}=$ poor.

\section{MDF and Mean Grain Size of Titanomagnetites}

The carrier of magnetization of the rocks is titanomagnetite (see section on opaque mineralogy, above). The mean grain diameter of the magnetic titanomagnetites varies from $<1$ to $20 \mu \mathrm{m}$. If the composition of the titanomagnetites in the rocks does not vary appreciably, inverse relationships should exist between grain diameter and magnetic stability.

Figure 27 shows a plot of mean grain size of titanomagnetites versus MDF (as a measure of stability). Although the rocks of Unit II show this inverse relationship, the rocks of Units I, III, and IV do not follow this simple relationship. This indicates that changes in the composition and/or oxidation state of the titanomagnetites predominates in these units.

\section{Comparison With Hole 396}

Hole 396 is about 500 meters southwest of Hole 396B and belongs to the same positive geomagnetic anomaly. The magnetic measurements were conducted by P. Johnson and are published in the Leg 45 Initial Reports of the Deep Sea Drilling Project.

In both holes, there is an upper unit of about equal thickness and normal polarity but slightly different inclination and petrography (phyric in Hole 396 and sparsely phyric in Hole 396B). The mean stable inclination of the upper unit of Hole 396 is $+34.4^{\circ}$, which is much closer to the theoretical central dipole value at the site of drilling $\left(+40.3^{\circ}\right)$, as compared to the $+20.8^{\circ}$ of Unit 1 , Hole 396B. Table 11 compares the different magnetic parameters of the two Holes 396B and 396.

The similarity in inclination of Unit III in Hole 396B $\left(-6^{\circ}\right)$ and the lower unit in Hole $396\left(-5^{\circ}\right)$ is conspicuous. One may correlate Unit I of Hole 396B with the upper unit of Hole 396, and also Unit III of Hole 396B with the lower unit of Hole 396. Unit II in Hole 396B does not have an equivalent in Hole 396.

Different explanations are possible for the shallow inclination of Units I and III of Hole 396B and the lower unit of Hole 396. One explanation is that they extruded during a period of geomagnetic reversal. However, we 
TABLE 9

Mean Values of Magnetic Parameters of Hole 396B

\begin{tabular}{lcccc}
\hline & Unit I & Unit II & Unit III & Unit IV \\
\hline Stable inclination & +20.8 & -69.3 & -6.0 & +27.2 \\
Standard deviation & 9.3 & 6.5 & 3.7 & 18.0 \\
Intensity $\left(\mathrm{emu} / \mathrm{cm}^{3}\right.$ ) & $0.85 \times 10^{-3}$ & $1.10 \times 10^{-3}$ & $2.70 \times 10^{-3}$ & $2.11 \times 10^{-3}$ \\
Standard deviation & $0.50 \times 10^{-3}$ & $1.05 \times 10^{-3}$ & $1.70 \times 10^{-3}$ & $0.58 \times 10^{-3}$ \\
\hline
\end{tabular}

TABLE 10

Comparison of Magnetic, Chemical, and Petrographic Unit Boundaries of Hole 396B

\begin{tabular}{l|c|c}
\hline $\begin{array}{c}\text { Magnetic } \\
\text { Unit } \\
\text { Boundary }\end{array}$ & $\begin{array}{c}\text { Chemical } \\
\text { Units }\end{array}$ & $\begin{array}{c}\text { Petrographic } \\
\text { Units }\end{array}$ \\
\hline I/II & - & - \\
II/III & $\mathrm{A}_{3} / \mathrm{B}_{1}$ & $3 / 4$ \\
III/IV & $\mathrm{B}_{2} / \mathrm{C}$ & $4 / 5$ \\
IV & - & $5 / 6$ \\
\hline
\end{tabular}

discount this explanation because the magnetization directions are very consistent in both Units I and III (although they are fairly thick), and because the intensity of magnetization (at least for Unit III) seems too high for a reversal period. Another explanation for the shallow inclinations is tilting of the area where Holes 396 and 396B have been drilled.

\section{Seismic Velocity, Density, and Porosity}

Measurements of seismic velocity (three components), density, and porosity were made of samples onboard. These measurements are discussed by Matthews (this volume).

\section{Thermal Conductivity Measurements}

\section{Sediments}

Thermal conductivity measurements were made aboard ship on the sediment cores using the needle-probe method described by von Herzen and Maxwell (1959). This method measures the temperature increase in the sediment caused by heat released within the sediment, as a function of time using a long, thin-walled hypodermic needle containing a heating element and a thermistor. The temperature increase is recorded in analog form and digitized, and a curve of the form $\mathrm{T}=\mathrm{A}+\mathrm{Bt}+\mathrm{C} \ln (\mathrm{t})$ is fitted to the temperature $(\mathrm{T})$ versus time $(t)$ data using a nonlinear regression program. Reduction of the data in this manner permits the removal of nearly linear temperature changes arising from the difference in ambient temperature between the sediment core and the laboratory.

The results of the thermal conductivity measurements made during Leg 46 are listed in Table 12. Conductivity data from both Holes 396A and 396B have been combined in Figure 28.

The mean of the five conductivity values measured in a single section of severely disturbed, totally unconsolidated nannofossil-foraminifer ooze recovered from just below the mudline at Hole $396 \mathrm{~A}$ is $2.84 \pm 0.07 \mathrm{mcal} / \mathrm{cm}^{2} \mathrm{sec}^{\circ} \mathrm{C}$.

It is apparent that the 18 conductivity values measured in sediments recovered from 122.50 to 142.27 meters

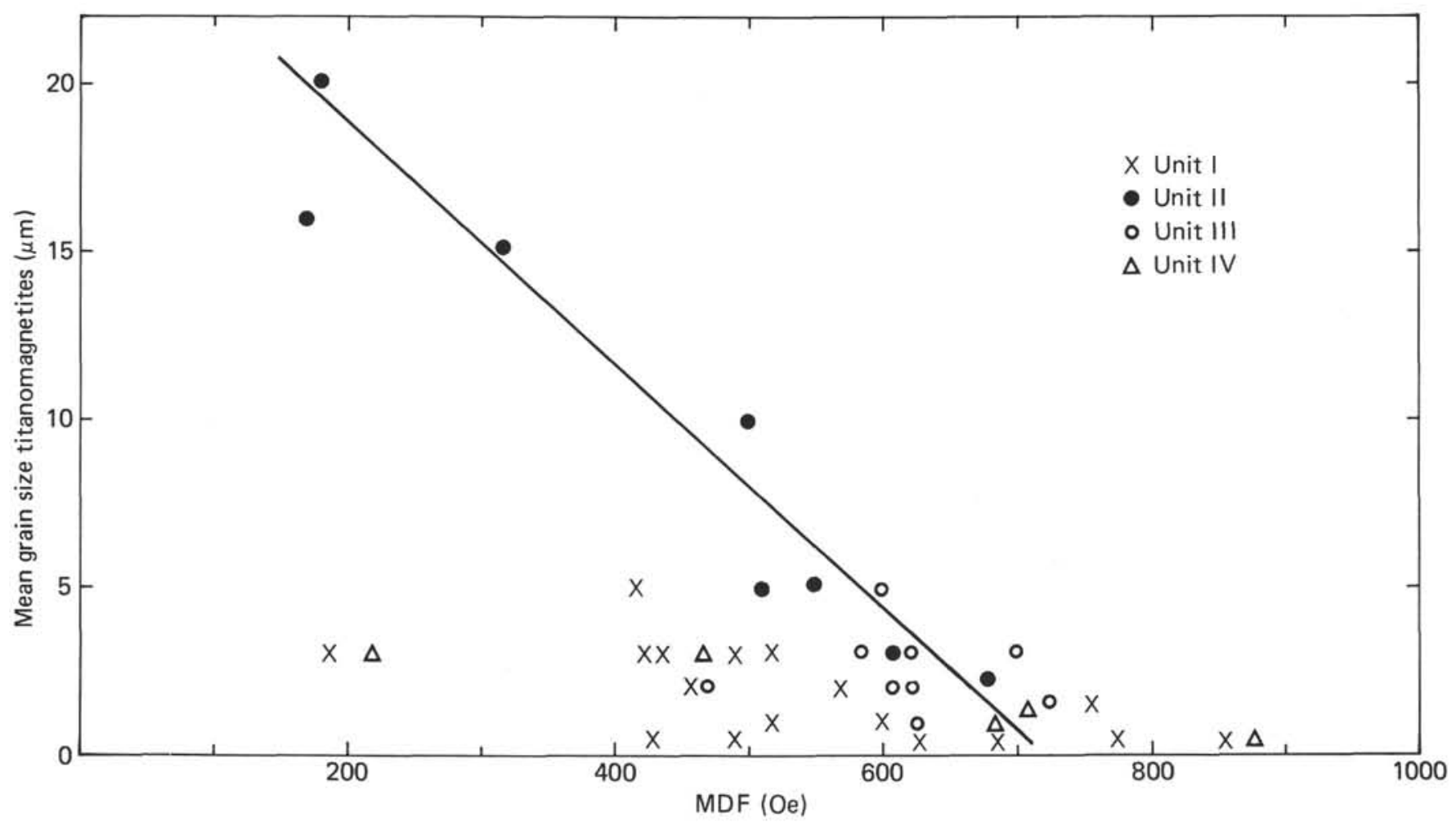

Figure 27. Mean grain size of titanomagnetite versus medium destructive field magnetic stability. 
TABLE 11

- Comparison of Magnetic Parameters of Holes 396B and 396 (data from Hole 396 from P. Johnson, Initial Report, DSDP Leg 45)

\begin{tabular}{lccccc}
\hline & Unit 1 & $\begin{array}{c}\text { Hole 396B } \\
\text { Unit II }\end{array}$ & Unit III & Upper Unit & Lower Unit \\
\hline $\begin{array}{l}\text { Mean } \\
\text { Stable }\end{array}$ & $+20.8^{\circ}$ & $-69.3^{\circ}$ & $-6.0^{\circ}$ & $+34^{\circ}$ & $-5^{\circ}$ \\
$\begin{array}{l}\text { Inclination } \\
\begin{array}{l}\text { Mean } \\
\text { NRM intensity } \\
\left(\mathrm{emu} / \mathrm{cm}^{3}\right)\end{array}\end{array}$ & $0.85 \times 10^{-3}$ & $1.90 \times 10^{-3}$ & $2.70 \times 10^{-3}$ & $1.20 \times 10^{-3}$ & $2.32 \times 10^{-3}$ \\
\hline
\end{tabular}

TABLE 12

Thermal Conductivity Values Measured on Sediment Recovered From Holes 396A and 396B

\begin{tabular}{|c|c|c|}
\hline $\begin{array}{c}\text { Sample } \\
\text { (Interval in } \mathrm{cm} \text { ) }\end{array}$ & $\begin{array}{l}\text { Depth } \\
\text { (m) }\end{array}$ & $\begin{array}{l}\text { Conductivity } \\
\left(\mathrm{mcal} / \mathrm{cm} \mathrm{sec}{ }^{\circ} \mathrm{C}\right)\end{array}$ \\
\hline $396 \mathrm{~A}-1-1,106$ & 1.04 & 2.95 \\
\hline $396 \mathrm{~A}-1-1,115$ & 1.15 & 2.78 \\
\hline $396 \mathrm{~A}-1-1,122$ & 1.22 & 2.80 \\
\hline $396 \mathrm{~A}-1-1,131$ & 1.31 & 2.76 \\
\hline $396 \mathrm{~A}-1-1,140$ & 1.40 & 2.89 \\
\hline $396 \mathrm{~B}-1-1,50$ & 122.50 & 3.27 \\
\hline 396B-1-1, 66 & 122.66 & 3.05 \\
\hline $396 \mathrm{~B}-1-1,80$ & 122.80 & 3.07 \\
\hline $396 \mathrm{~B}-1-1,112$ & 123.12 & 3.05 \\
\hline 396B-1-1, 135 & 123.35 & 3.01 \\
\hline $396 \mathrm{~B}-1-2-10$ & 123.60 & 2.70 \\
\hline $396 \mathrm{~B}-1-2,18$ & 123.68 & 2.75 \\
\hline $396 \mathrm{~B}-1-2,25$ & 123.75 & 2.95 \\
\hline $396 \mathrm{~B}-2-1,53$ & 132.03 & 3.51 \\
\hline $396 \mathrm{~B}-2-1,61$ & 132.11 & 3.38 \\
\hline 396B-2-1, 79 & 132.29 & 3.30 \\
\hline $396 \mathrm{~B}-2-1,100$ & 132.50 & 3.03 \\
\hline 396B-2-1, 119 & 132.69 & 2.68 \\
\hline 396B-2-1, 132 & 132.82 & 3.15 \\
\hline 396B-3-1, 76 & 141.76 & 2.86 \\
\hline $396 \mathrm{~B}-3-1,90$ & 141.90 & 2.67 \\
\hline $396 \mathrm{~B}-3-1,106$ & 142.06 & 2.96 \\
\hline $396 \mathrm{~B}-3-1,127$ & 142.27 & 3.29 \\
\hline
\end{tabular}

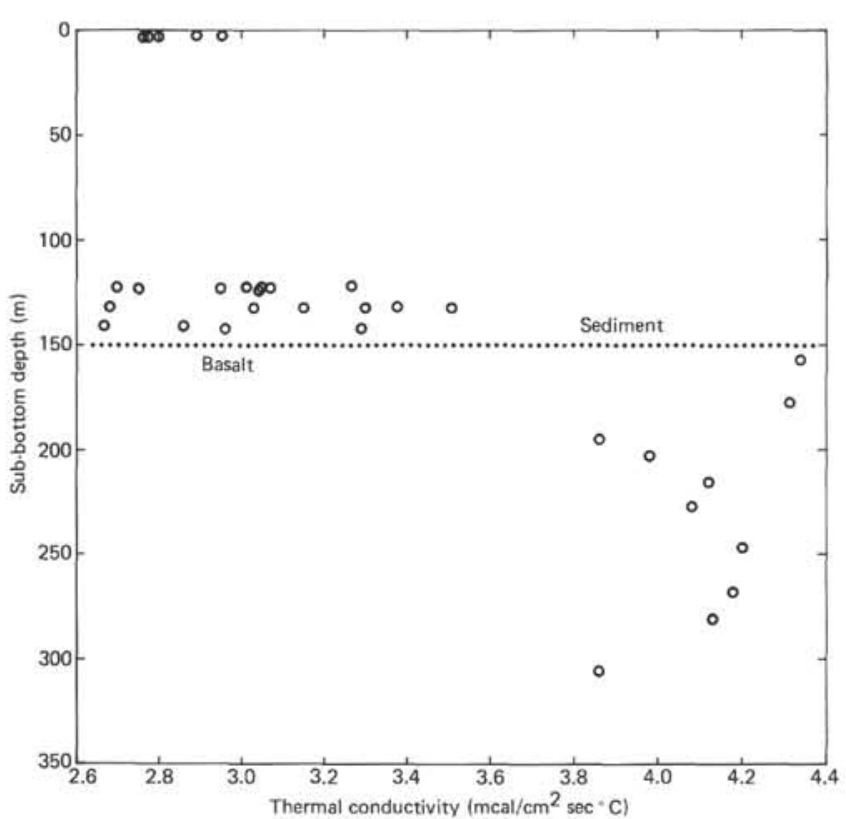

Figure 28. Thermal conductivity versus depth for Hole $396 B$ sediments. sub-bottom in Hole 396B are highly variable, with a mean and standard deviation of $3.04 \pm 0.24 \mathrm{mcal} / \mathrm{cm}^{2} \mathrm{sec}^{\circ} \mathrm{C}$. Mean thermal conductivity values calculated for each of the four sections from which data were available (Table 13), although quite variable, show no systematic variation with depth. Cores 1 and 2 at Hole 396B are comprised of nannofossil ooze; Core 3 is described as marly nannofossil ooze. All cores were severely to moderately disturbed by drilling.

\section{Basalt}

The thermal conductivity and wet density of 10 basalt samples from Hole 396B were measured using a divided bar apparatus with constant temperature ends (Jessop, 1970). Values for the quartz and fused-silica standards used in the apparatus were from Ratcliffe (1959). The basalt samples were in the form of discs, $2.5 \mathrm{~cm}$ in diameter by $1.0 \mathrm{~cm}$ thick, that were cut from small cores (minicores) drilled from chunks of basalt. The basalt chunks had been stored in water aboard the D/V Glomar Challenger from immediately after their recovery until their conductivity was measured.

The mean sample temperature was about $25^{\circ} \mathrm{C}$, and the accuracy of individual values is better than 5 per cent (Table 14). The harmonic mean conductivity is $4.08 \pm 0.05$ $\mathrm{mcal} / \mathrm{cm}^{2} \mathrm{sec}^{\circ} \mathrm{C}$, very similar to that measured previously on sea-floor basalts (Hyndman and Drury, 1976). The measured thermal conductivity may be much lower than the in situ conductivity; however, the difference cannot be from incomplete saturation since these samples were formed on the ocean floor and were maintained saturated until measurement.

TABLE 13

Means and Standard Deviations of Thermal Conductivity Values Measured Within the Sections Listed in Table 12

\begin{tabular}{cccc}
\hline & \multicolumn{3}{c}{$\begin{array}{c}\text { Deviation } \\
\left(\mathrm{mcal} / \mathrm{cm}^{2} \sec ^{\circ} \mathrm{C}\right) \\
\text { Standard }\end{array}$} \\
Section & Mean & $\begin{array}{c}\text { Standion } \\
\text { Deviation }\end{array}$ & N \\
\hline $1-1$ & 3.09 & 0.09 & 5 \\
$1-2$ & 2.80 & 0.11 & 3 \\
$2-1$ & 3.18 & 0.27 & 6 \\
$3-1$ & 2.95 & 0.22 & 4 \\
\hline
\end{tabular}

TABLE 14

Thermal Conductivity Values Measured on Samples of Basalt Recovered From Hole 396B During DSDP Leg 46

\begin{tabular}{lccc}
\hline $\begin{array}{c}\text { Sample } \\
\text { (Interval in cm) }\end{array}$ & $\begin{array}{c}\text { Depth } \\
(\mathrm{m})\end{array}$ & $\begin{array}{c}\text { Conductivity } \\
\left(\mathrm{mcal}^{\mathrm{cm}} \mathrm{cm}^{2} \mathrm{sec}^{\circ} \mathrm{C}\right)\end{array}$ & $\begin{array}{c}\text { Wet Density } \\
\left(\mathrm{gm} / \mathrm{cm}^{3}\right)\end{array}$ \\
\hline $5-1,61-63$ & 157.62 & 4.34 & 2.61 \\
$7-3,9-11$ & 177.10 & 4.34 & 2.80 \\
$9-2,39-41$ & 194.90 & 3.86 & 2.66 \\
$10-1,57-59$ & 203.08 & 3.98 & 2.83 \\
$12-1,103-105$ & 215.54 & 4.12 & 2.82 \\
$14-2,73-75$ & 227.74 & 4.08 & 2.82 \\
$16-2,71-73$ & 246.72 & 4.20 & 2.84 \\
$17-1,69-71$ & 268.70 & 4.18 & - \\
$20-3,137-139$ & 290.87 & 4.13 & 2.75 \\
$22-1,45-47$ & 305.96 & 3.86 & 2.75 \\
\hline
\end{tabular}




\section{DOWNHOLE EXPERIMENTS — HOLE 396B}

\section{Downhole Logging}

Hole 396B is the first hole in oceanic crust to be logged by downhole geophysical instruments. The tools run are: (1) Borehole Compensated Sonic with integrated travel time and natural gamma-ray activity; (2) Compensated Neutron Porosity, Compensated Formation Density, calipers, and natural gamma-ray activity; and (3) Dual Induction Electrical Log (ILD, ILM, and LL8) and natural gamma-ray activity. All tools were supplied by Schlumberger, Ltd. The data were obtained both digitally and optically. The computer-processed logs are presented in Figure 29. Corrections must be made to the neutron porosity and ILM logs (Kirkpatrick, this volume), but the values from other logs need no correction.

\section{Logging Procedure}

All logs were run in open hole upward from the maximum depth obtainable to the base of the $11 \frac{3 / 4}{4}$ in . casing at 161 meters sub-bottom. During the logging runs, the bottom of the pipe was held about 160 meters above the bottom of the casing and the tools (33/8-in. O.D., except for the density log which was $3 \frac{1}{2} 2$-in. O.D.) were lowered through a modified drill bit with a 37/8-in. opening. Because of this small opening, none of the positioning devices (centralizers and decentralizers) could be used. This is the cause of the large scatter in the data. Because the tools used are compensated (dual detector), however, the average value for an interval is relatively accurate. There may be some additional scatter in the data due to raising and lowering the tool by the ship's roll. No unambiguous examples of this have been found in the data.

\section{Applications of the Data}

The objectives of the logging were to obtain in situ physical property data, to obtain some idea of the nature of the material not recovered, and to determine lithologic boundaries in intervals of poor recovery. Except for neutron porosity, which is 10 to 12 per cent less than the uncorrected $\log$ value, the data in the logs in Figure 29 give a good indication of the in situ values for the properties measured. The integrated sonic velocity for the interval logged is 3.1 $\mathrm{km} / \mathrm{sec}$. All the logs indicate an in situ value much lower (higher for porosity) than the laboratory values obtained on core samples/corrected neutron.

Plots of density versus porosity (Kirkpatrick, this volume) indicate that the grain density of the material around the borehole is in the range of 2.8 to $3.0 \mathrm{~g} / \mathrm{cm}^{3}$, the same as the basalt recovered, implying that the material not recovered is primarily basalt.

The main boundary in Hole 396B defined by the logs is that between the palagonite breccia unit (Unit 5) and the upper sand and gravel unit (Unit 6) at 340 meters sub-bottom. Recovery was very poor in this interval, but the abrupt decrease in density, sonic velocity (increase in interval transit time), and electrical resistivity indicate the boundary clearly. The boundary between the porphyritic basalt unit (Unit 4) and the palagonite breccia unit (Unit 5) also is indicated clearly by the logs, although recovery was sufficient to define the boundary.
The natural gamma-ray log indicates clearly intervals of palagonite breccia at the top of lithologic Unit 1 and in lithologic Units 6,7 , and 8 . This $\log$ is sensitive to $\mathrm{K}^{40}$ and elements in the uranium and thorium decay series and, most likely, is detecting increased potassium levels due to the palagonitization.

The spike in the density, porosity, and interval transit time logs at 230 meters is consistent with the idea that the boundary between magnetic Units I and II may be a fault.

The large and rapid fluctuations in the upper parts of both the sparsely phyric (Units 1 and 2) and porphyritic (Unit 4) pillow sequences relative to the comparatively smooth curves in their lower parts appears to indicate that the upper parts are considerably less well-consolidated than the lower parts.

The flow or sill in Core 15 (Unit 3) is poorly defined and cannot easily be distinguished from the pillow sequences.

\section{Downhole Seismics}

We planned to rendezvous with the R/V Knorr on 8 March. The Knorr was to bring explosives, apparatus, and personnel in order to act as shooting ship for the Oblique Seismic Experiment. The greater part of the apparatus for recording these shots was embarked on board the Challenger and it was tested, as far as was possible in the absence of the shooting ship, on the night of 29 February-1 March. Subsequent damage to the drill rig caused these plans to be abandoned. In this section, the plans and the apparatus assembled are described very briefly and an account is given of results obtained with a hydrophone lowered into Hole 396B.

\section{Objectives of the Oblique Seismic Experiment}

1) To check the interval velocities obtained by sonic logging, by either explosions fired from the nearby Knorr or shots of the Challenger's airgun, recorded on a geophone lowered to various depths within the hole. Industrial experience suggests that such check shots, which sample rocks remote from the disturbed zone around the drill hole, generally record higher velocities than the downhole logs.

2) To find out how characteristic of the surrounding crust is the velocity structure intersected by the holes. This can be done by comparing travel times between shots (fired at ranges between 0 and $11 \mathrm{~km}$ by the Knorr) to a geophone clamped in the hole, with travel times computed assuming that the velocity structure found in the hole is typical of the surrounding crust.

3) To determine the effect of open cracks on the seismic velocities by comparing the observed velocities with those obtained in the laboratory in jacketed specimens subjected to external compacting pressures.

4) To study attenuation in the rocks by comparing amplitudes observed at various depths in the hole, both at normal and oblique incidence with amplitudes on computed synthetic seismograms.

\section{Apparatus}

A Wall-Lock Geophone (WLG) made by Geospace was available to lower out of the pipe on the Schlumberger logging cable. Once out of the pipe, it was to be locked against the wall of the open hole. The control box was 


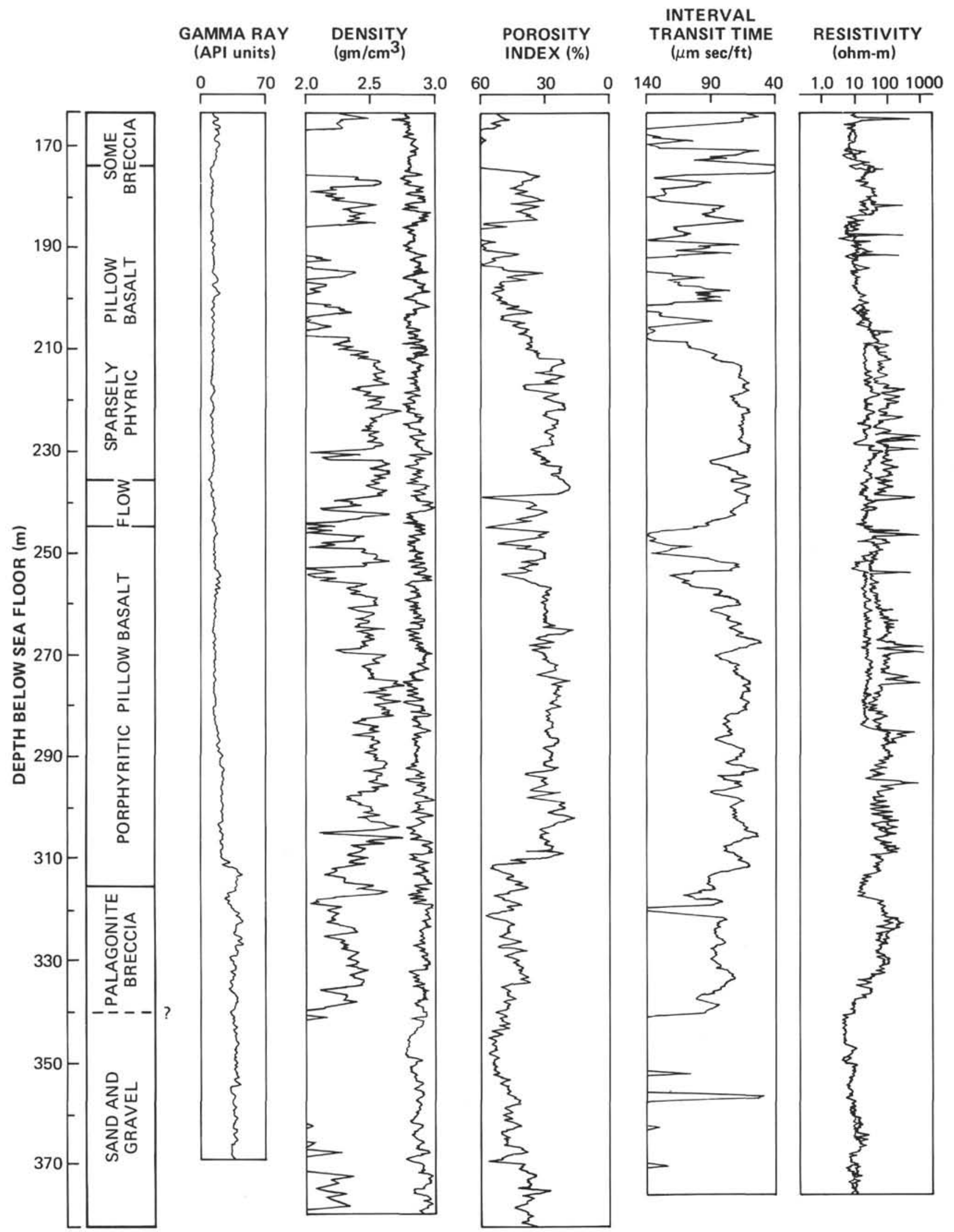

Figure 29. Downhole logs for Hole 396B. 
situated in the Schlumberger hut, whence the signal was led down through the elevator shaft to the recording apparatus in the Paleontology Lab. A weighted hydrophone hanging on 1000 feet of cable was to be deployed off the starboard side of the main deck to record the direct water wave from the Knorr's shot in order to determine the range. Shot instant was to be obtained either by direct VHF transmission of a tone break from the Knorr or, failing this, by timing the shots on two identical crystal clocks, one in the Knorr and the other in the Challenger. A special VHF radio system was installed in both ships to facilitate this interlaboratory communication. Two antennas were erected for it, one at the forward end of the pipe rack and the other on the stack.

In Challenger's laboratory apparatus was set up to record signals on tape and to display them on a jet-pen galvanometer recorder. It was possible to amplify or attenuate the signals from the WLG and the overside hydrophone by factors of 2 between $2^{11}$ and $2^{-5}$.

Onboard the Knorr, apparatus was installed to transmit the tone break when the explosion was detected by a geophone and also to record (and display) the shot and a time-encoding crystal clock.

\section{Trial, 29 February}

The WLG was locked in the drill pipe midway to the sea floor, 7000 feet under the ship. The overside hydrophone was put down to 900 feet depth. Someone whistled into the Bridge VHF and was received on the Lab VHF. All seven channels were recorded in the lab both on and off tape. No difficulties were encountered except that the WLG preamplifier was frequently overloaded with noise.

\section{The Cambridge Hydrophone}

When its locking arm is closed, the WLG has a diameter of 3.62 inches. The special bit through which the Schlumberger logging tools were lowered has a ring of interval diameter of 3.75 inches on which the EDO-Western re-entry tool seats, so the clearance around the WLG is only $1 / 16$ inch. This does not leave much room for small bits of basalt to get into the arm mechanism, preventing it from retracting completely. Accordingly, it had been agreed that we must run this tool into the hole lastly, and must regard it as possibly sacrificial in spite of its $\$ 15,000$ replacement value. As a second line of defense if the WLG were lost, we had a Cambridge-built hydrophone. The hydrophone has an outside diameter of 2.55 in. so it will not fit through the normal drilling bit, interval diameter 2.46 in., but is an easy fit through the special logging bit, 3.75-in. I.D.

The hydrophone was built to attach to a Gearhart-Owen connector; in order to use it, we needed to cut off the ten-pin adaptor and rope socket used to attach the WLG (and the other logging tools) to the Schlumberger cable and to replace it with the Gearhart-Owen connector normally used to connect the EDO re-entry tool. The Cambridge hydrophone contains a preamplifier with a gain of $14 \times$ which draws its power from the surface.

\section{Downhole Hydrophone Experiment, 1 March}

The Cambridge hydrophone, attached to a 12-foot sinker bar, was lowered into the open hole beyond the end of the casing. A 40-in. ${ }^{3}$ airgun, floated astern on a buoy, was fired at a depth of about 15 feet and a pressure of $1500 \mathrm{psi}$, once every 15 seconds. Arrangements were made in the laboratory to record the electrical firing pulse of the airgun, the crystal clock, and the signal from the downhole hydrophone.

A typical record showed irregularly spaced bursts of noise, about two clangs every second. There is no reason to believe that there was anything wrong with the hydrophone, so the noise must be real. It might be due to the drill pipe clanging in the cone and casing, to jerks of the cable on which the hydrophone was hanging, or to the sinker bar clanging against the side of the hole. The direct sound travel time from the airgun to the hydrophone was expected to be slightly more than 3 seconds; a careful attempt was made to find correlatable arrivals in this interval. Records of several shots were played out at high paper speeds for several depths of the hydrophone in the hole. No consistent arrivals were found; apparently, the airgun is too small a source. A similar conclusion was reached in a similar experiment using the DSDP (Lamont) hydrophone on Leg 45.

Unfortunately, the Cambridge hydrophone had not been calibrated so the intensity of the noise in the pipe was not known.

\section{REFERENCES}

Bryan, W.B. and J.G. Moore, 1977. Compositional variations of young basalts in the Mid-Atlantic Ridge rift valley near $36^{\circ} 49^{\prime}$ N, Geol. Soc. Am. Bull., v. 88, p. 556-570.

Bukry, D., 1978. Neogene coccolith stratigraphy, Mid-Atlantic Ridge, Deep Sea Drilling Project, Leg 45. In Melson, W. and Rabinowitz, P., et al., Initial Reports of the Deep Sea Drilling Project, v. 45, Washington (U.S. Government Printing Office).

Flanagan, F.J., 1972. Values for international geochemical reference samples, Geochim. Cosmochim. Acta, v. 37, p. 1189-1200.

Frey, F.A., Bryan, W.B., and Thompson, G., 1974. Atlantic Ocean floor: geochemistry and petrology of basalts from Legs 2 and 3 of the Deep Sea Drilling Project, J. Geophys. Res., v. 35 , p. $5507-5528$.

Hyndman, R.D. and Drury, M.J., 1976. The physical properties of oceanic basement rocks from deep drilling on the Mid-Atlantic Ridge, J. Geophys. Res., v. 81, p. 4042.

Jessop, A.M., 1970. The effect of environment on divided bar measurements, Tectonophysics, v. 10, p. 39.

Miyashiro, A., Shido, F., and Ewing, M., 1970. Crystallization and differentiation in abyssal tholeiites and gabbros from mid-ocean ridges, Earth Planet Sci. Lett., v. 7, p. 361-365.

Purdy, G.M., Rabinowitz, P.D., and Schouten, H., 1978. The mid-Atlantic Ridge at $23^{\circ} \mathrm{N}$ : Bathymetry and Magnetics. In Melson, W., and Rabinowitz, P., et al., Initial Reports of the Deep Sea Drilling Project, v. 48, Washington(U.S. Government Printing Office).

Ratcliffe, E.H., 1959. Thermal conductivities of fused and crystalline quartz, British J. Appl. Phys., v. 10, p. 22.

von Herzen, R.P. and Maxwell, A.E., 1959. The measurement of thermal conductivity of deep-sea sediments by a needle probe method, J. Geophys. Res., v. 64, p. 1557. 

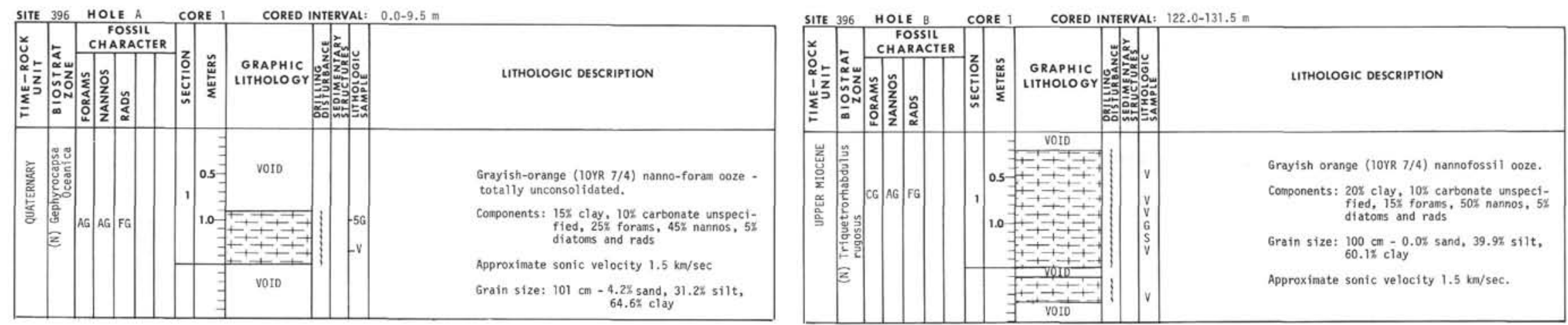

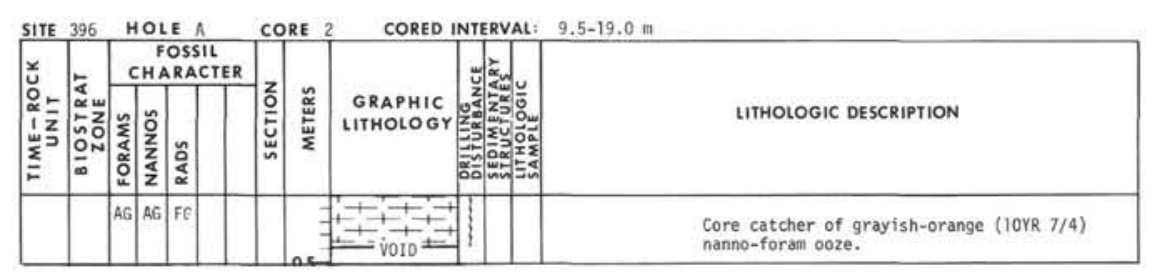

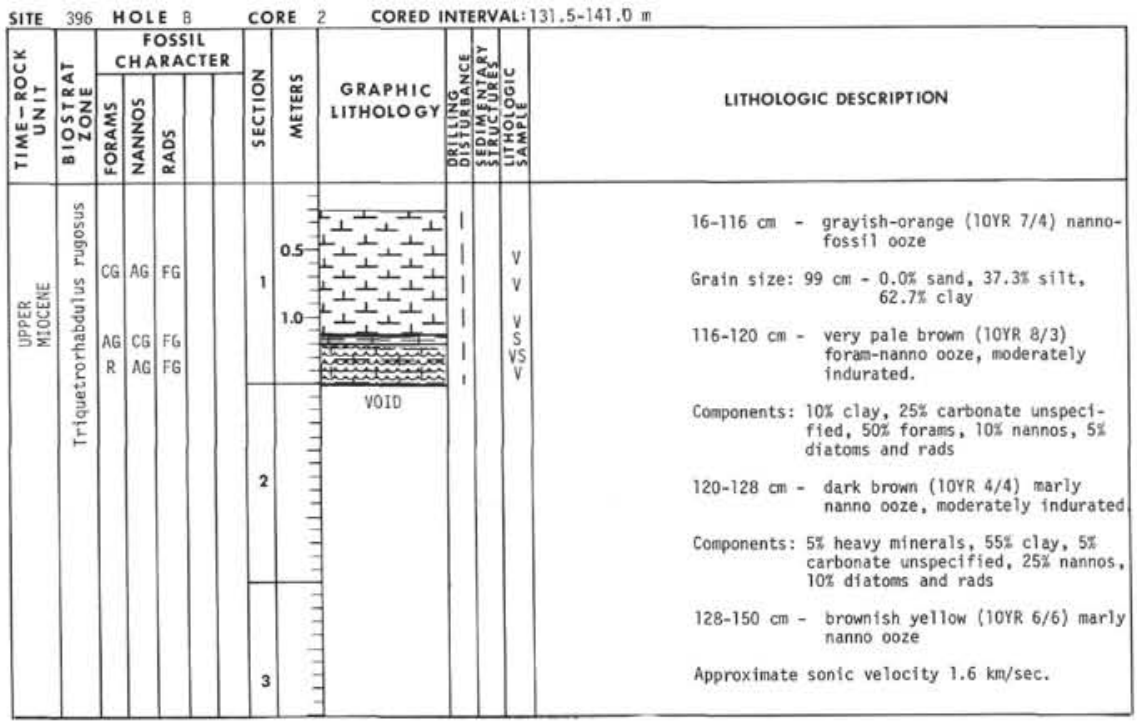

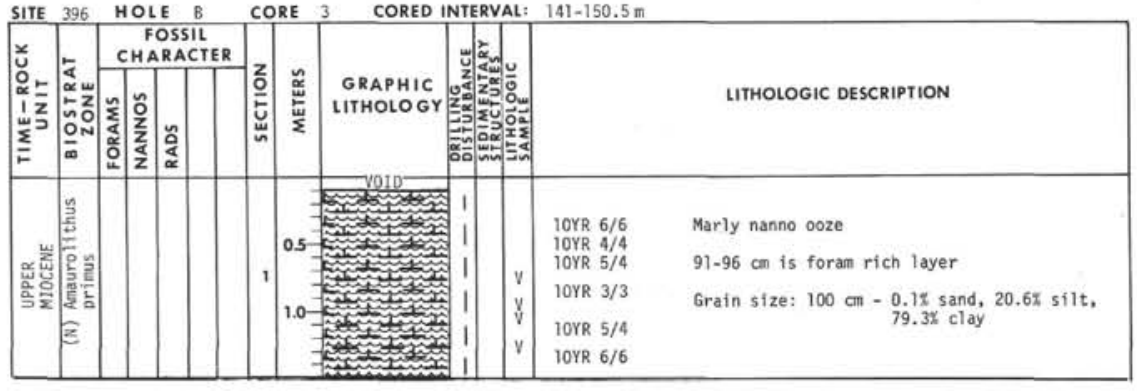




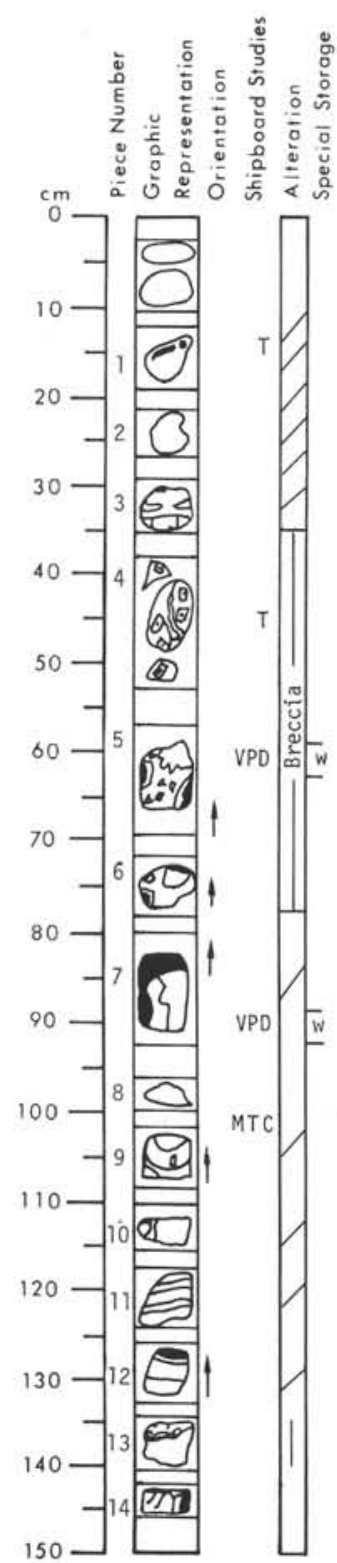

\section{VISUAL CORE DESCRIPTION
FOR IGNEOUS ROCKS}

2-10 cm-Marly nannofossil ooze, 0iscoaster exilits zone, niddle Miocene, about $13 \mathrm{~m}$. Visual Description

Structure: pillow lava sequence with 4 subdivisions: 1$)$ aitered basalt $(10-35 \mathrm{~cm})$

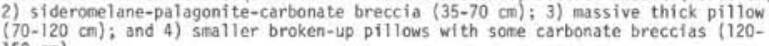

Texture: Doninantly pillow rinds, generally with variolitic zones, about $30 \mathrm{~s}$ nore Mineralogy: Very sparsely olivine-phyric (much less than $1 *$ beconing slightly more Size of phenocrysts generally less than $1 \mathrm{~mm}$. Vesicles generally
round to irreguler, partly filled with clays $(?)$, rarely carbonate.

Alteration: Relatively fresh except for about $1 \mathrm{~cm}$ wide alteration halos around

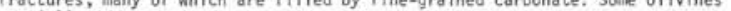
partially lddingsitized, sone sideromelane partly palagontized, protivi Thin Section Description

Phenocrysts: less than $1 \%$ olivine and plagioclase

Groundrass: 011vine, $5 \%, 0.1-0.2 \mathrm{~m}$, skeletal; plagioclase, 30\%, 0.1-0.5 m.

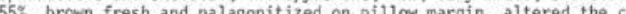

Vesicles: $1 x$, less than $1 \mathrm{~mm}$

Texture: holohayline, variolitic, intersertal

Alteration: clay partially filling vesicles

Shipboard Data

Bulk Analysis: 103-105 con

$\mathrm{SiO}_{2} \quad 49.91 \quad \mathrm{MnO}$

0.18

Magnetic Data: $103-105$ co

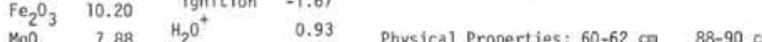

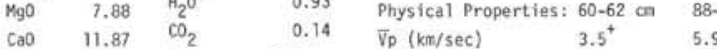

$\begin{array}{lllllll}\mathrm{Na}_{2} \mathrm{O} & 2.53 & \mathrm{Cr} & 355.0 & \text { Porosity }(\mathrm{x}) & 35.0 & 7.0\end{array}$

$\begin{array}{lllllll}\mathrm{K}_{2} \mathrm{O} & 0.28 & \mathrm{Ni} & 146.0 & \text { Wet Bulk Density } & 1.92 & 2.72 \\ \mathrm{~T}^{2} & 1.43 & \mathrm{Sr} & 126.0 & \text { Grain Density } & 2.40 & 2.85\end{array}$

$\begin{array}{lll}\mathrm{P}_{2} \mathrm{O}_{5} & 0.15 & \mathrm{Z}\end{array}$

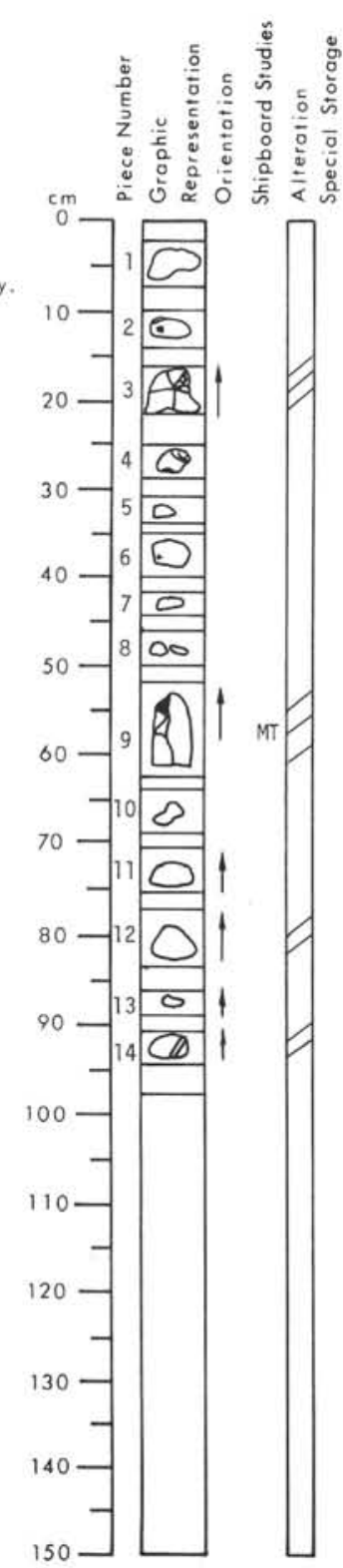

VISUAL CORE DESCRIPTION FOR IGNEOUS ROCKS

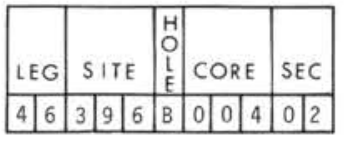

Depth: $152.0 \mathrm{~m}$ to $153.5 \mathrm{~m}$

Visual Description

Structure: Pillow lave sequence.

Texture: Dominantly pfllow rinds with variolitic zones.

Mineralogy: Very sparsely olivine phyric with rare plagioclase phenocrysts $(<1 \mathrm{~m})$.

Aiteration: Relatively fresh, except near fractures. Glass partiy palagonitized, or

Thin Section Description

Groundrass: 011ivine, $3 \%, 0.1-0.2 \mathrm{~mm}$, skeletal; plagioclase, $30 x$, up to $0.3 \mathrm{~m}$.

Vesicles: $3 \pi, 0.2-0.4 \mathrm{~mm}$, empty

Texture: intersertal

Shipboard Data

intensity (envice) $1.63 \times 10^{-4}$

Stable inclination +11.0 


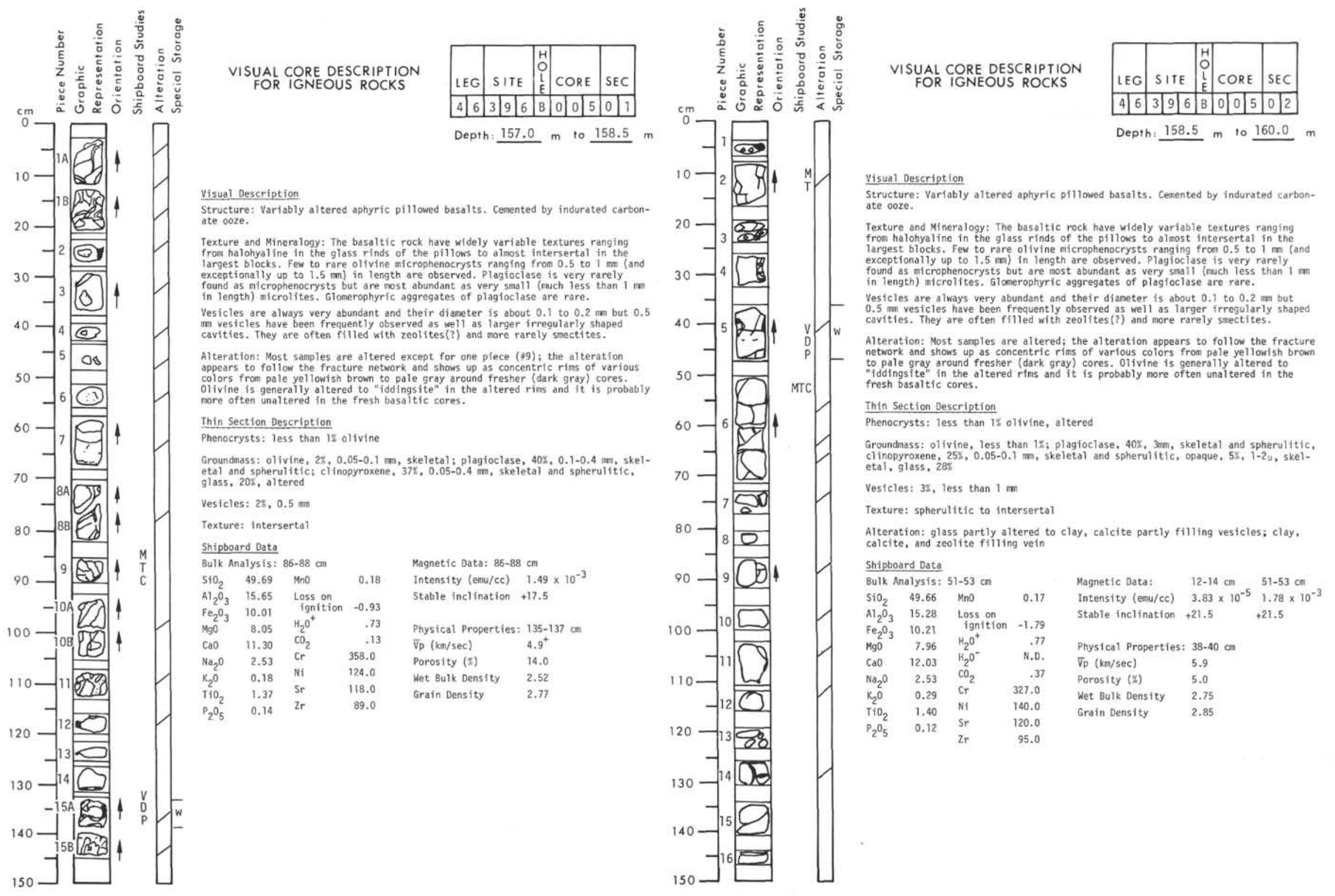




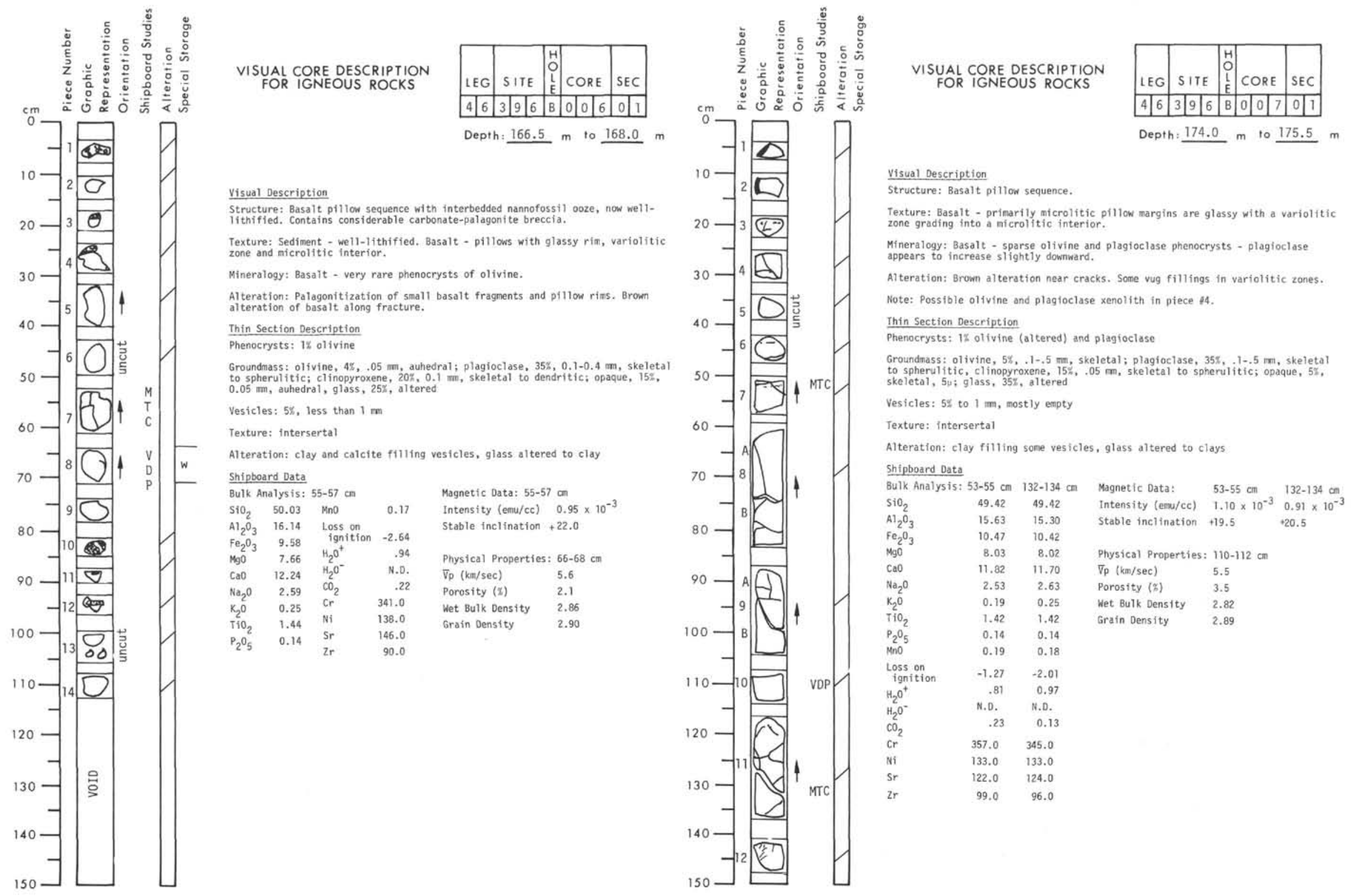




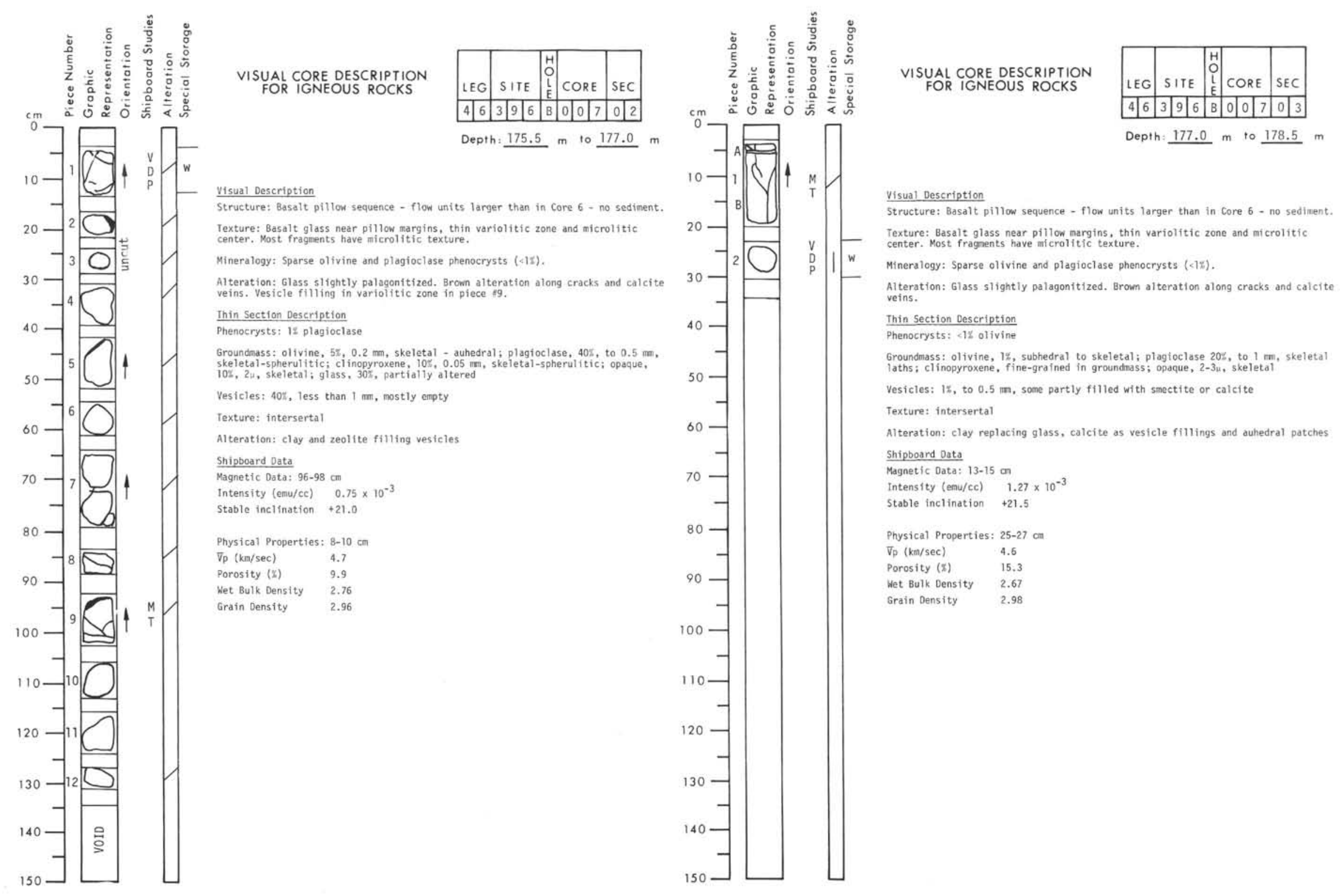




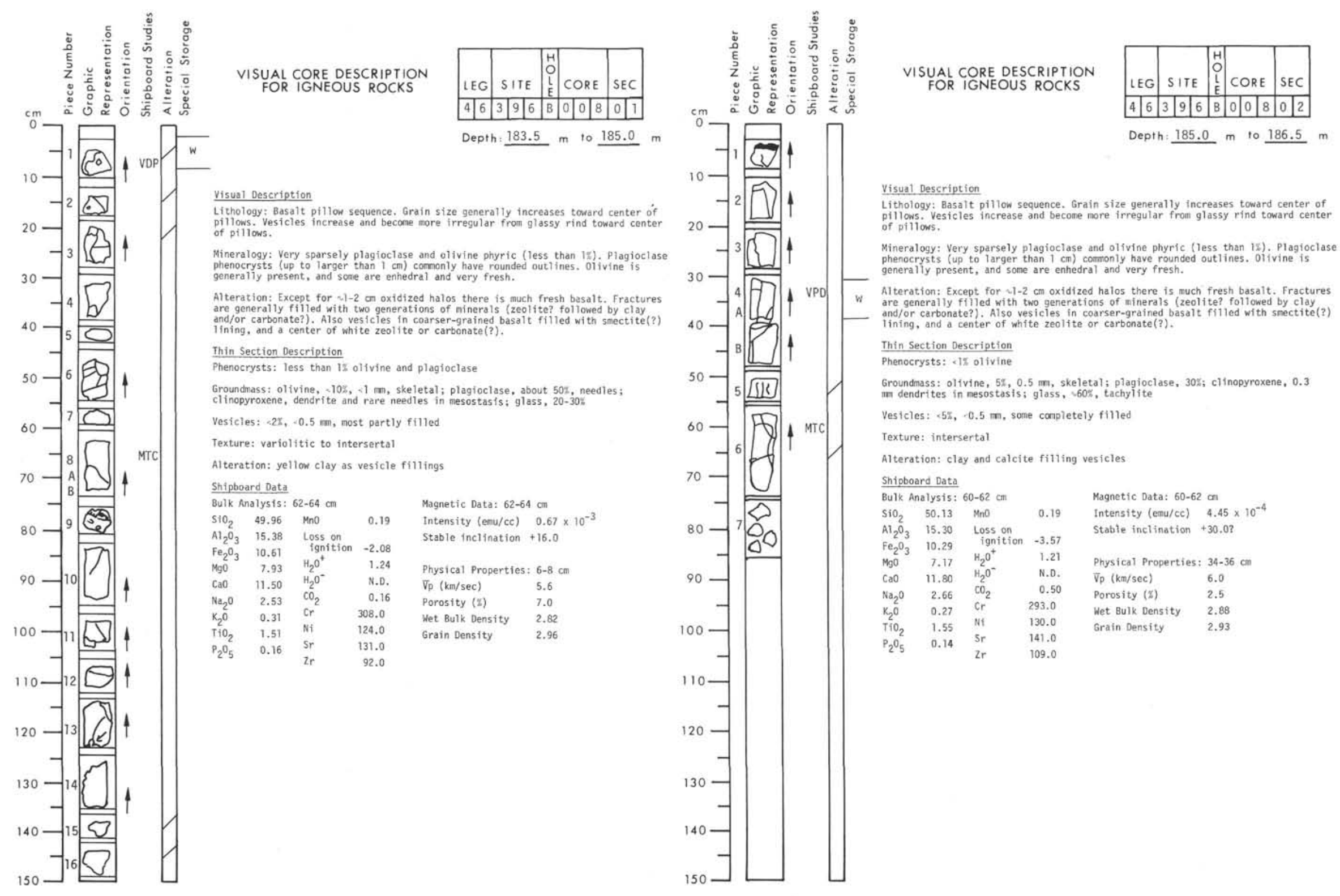




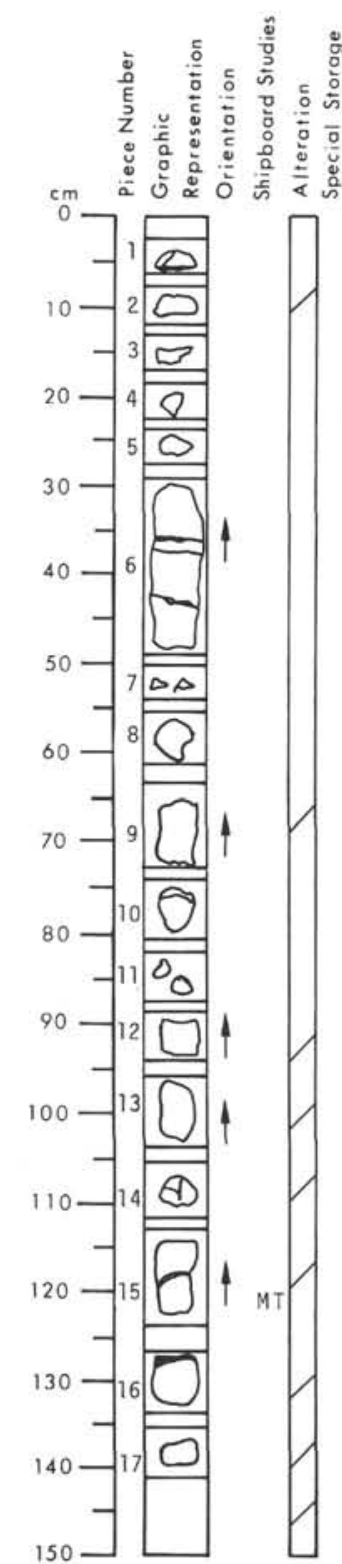

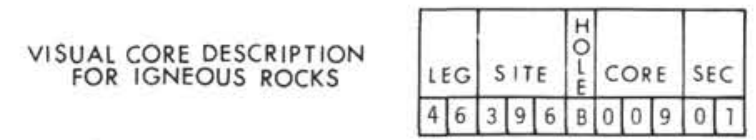

Visual Description

Lithology: Massive, vestcular, sparsely phyric basalt throughout with scattered
gl assy pillow rinds. The glassy margins grade insard to a variolitic zone in which brown al teration product. Pillow intervals are wellcrystallized. (Similar to core 8.)

Mineralogy: Plagioclase and olfvine phenocrysts are present in most samples. The Olivine phenocrysts are enhedral, fresh, and small $(i 1 \mathrm{~mm})$ but they are more abur-
dant than plagioclase $(5: 1)$. Plogioclase occurs as equant to elongate grains up. . Molt inclusions are present in the larger grains.

Alteration: Generally fresh with alteration occurring in $0.5-2 \mathrm{~cm}$ brown halos Olivines within brown halos are iddingsitized, Glassy maryins of pillow rinds are Thin Section Description

Phenocrysts: c1\% olivine and plagioclase

Groundass: ol ivine, <5\%, plagioclase, 30-50\%, up to $11 \mathrm{~m}$, needles; clinopyroxene, Vesicles: 1-2\%, cl min, about 1/2 filled

Texture: intersertal-variolitic

Alteration: glass altered to clay, clay and calcite filling vesicles Shipboard Data

Magnetic Data: $120-122 \mathrm{~cm}$

(ernu/cc) $1.21 \times 15^{-3}$

Stable inclination +20 .

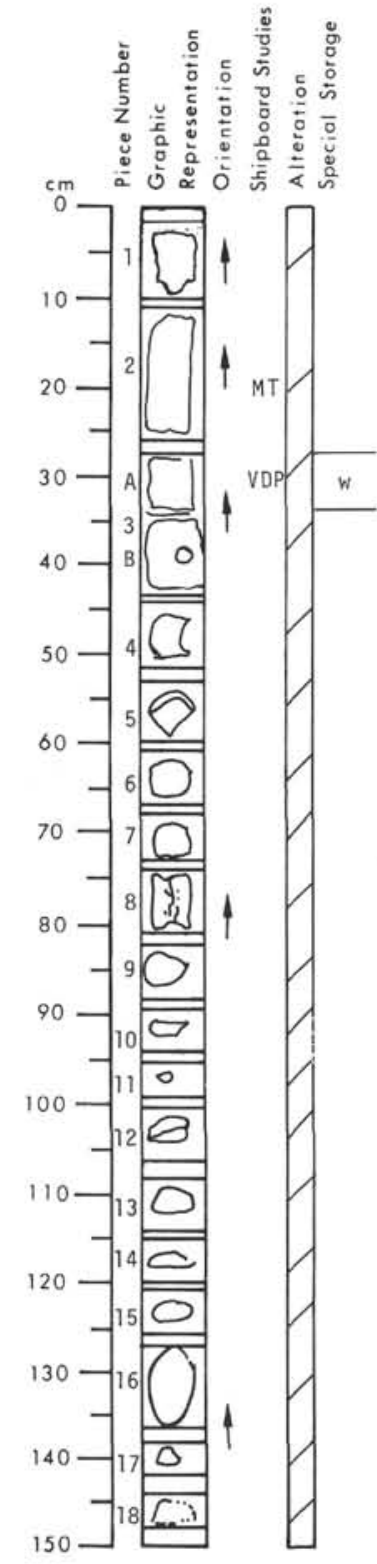

VISUAL CORE DESCRIPTION

FOR IGNEOUS ROCKS

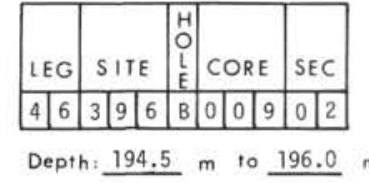

Visual Description

Lithology: Massive, vesicular, sparsely phyric basalt throughout with scattered glassy pillow rinds. The glassy margins grade inward to a variolitic zone in which crystallized, (Similar to Core B.

Mineralogy: Plagioclase and olivine phenocrysts are present in most samples. The dant than plagioclase (5:1). Plagiociase occurs as equant to elongate grains up to a

Alteration: Generally fresh with alteration occurring in 0.5-2 $\mathrm{cm}$ brown halos olivines withio brown halos are iddingsitized. Glassy margins of pilliow material. slightly palagonitized.

Thin Section Description

Phenocrysts: $11 \%$ olivine and plagioclase

Groundmass: 01 ivine, $5 \%, 0.2 \mathrm{~mm}$, auhedral; plagioclase, $30-40 \%, 0.5 \mathrm{~mm}$, needles and
laths; clinopyroxene, $0.2 \mathrm{~mm}$, auhedral to dendritic; 91 ass, $50 \mathrm{z}$, tachylite Vesicles: $<5 \%, 0.5 \mathrm{~mm}$, generally open

Texture: intersertal to variolitic

Alteration: a liftle colorless clay

Shipboard Data

Magnetic Data: 19-21 cm

Intensity (emu/cc) $1.13 \times 10^{-3}$

Stable inclination +20.0

Phystcal Properties: 29-31 co

$\nabla p(\mathrm{~km} / \mathrm{sec}) \quad 5.6$ 5.6

Wet Bulk Density $\quad 2.78$

Grain Density 2.90 


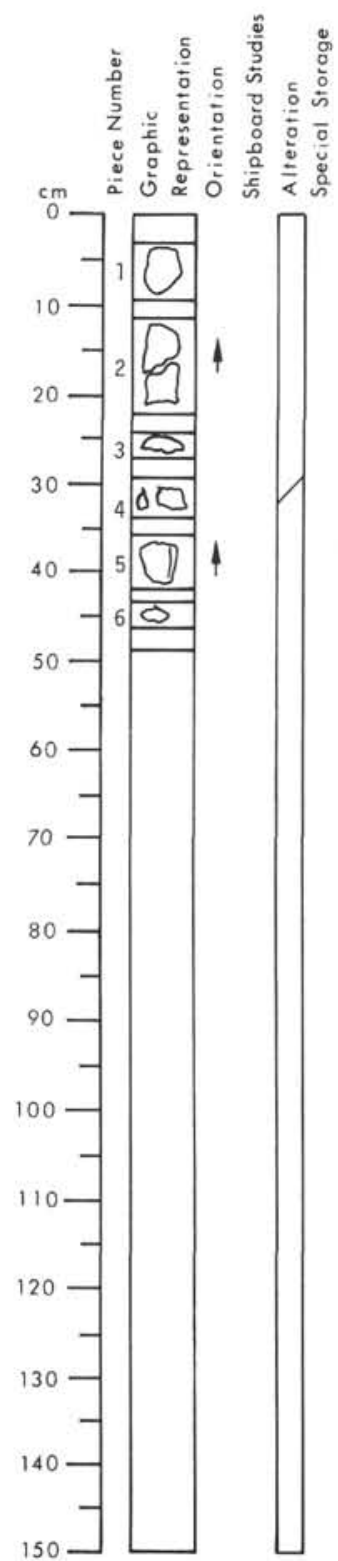

\section{VISUAL CORE DESCRIPTION
FOR IGNEOUS ROCKS}

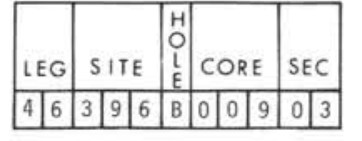

Visual Description

Lithology: Massive, vesicular, sparsely phyric basait throughout with scattered vesicles are filled with a brown atteration product. pillow intervals are wellcrystallized. (Similar to Core 8.)

Mineralogy: Plagioclase and ofivine phenocrysts are present in most samples. The ofivine phenocrysts are entedral, fresh, and mall (if 1 i) but they are more abun$1 \mathrm{~cm}$ in diameter. Melt inclusions are present in the larger grains.

Alteration: Generally fresh with alteration occurring in $0.5-2 \mathrm{~cm}$ brown halos 01 ivines within brown halos are iddinsitized. Glassy margins of pillow rinds are only slightly paragonitizized.

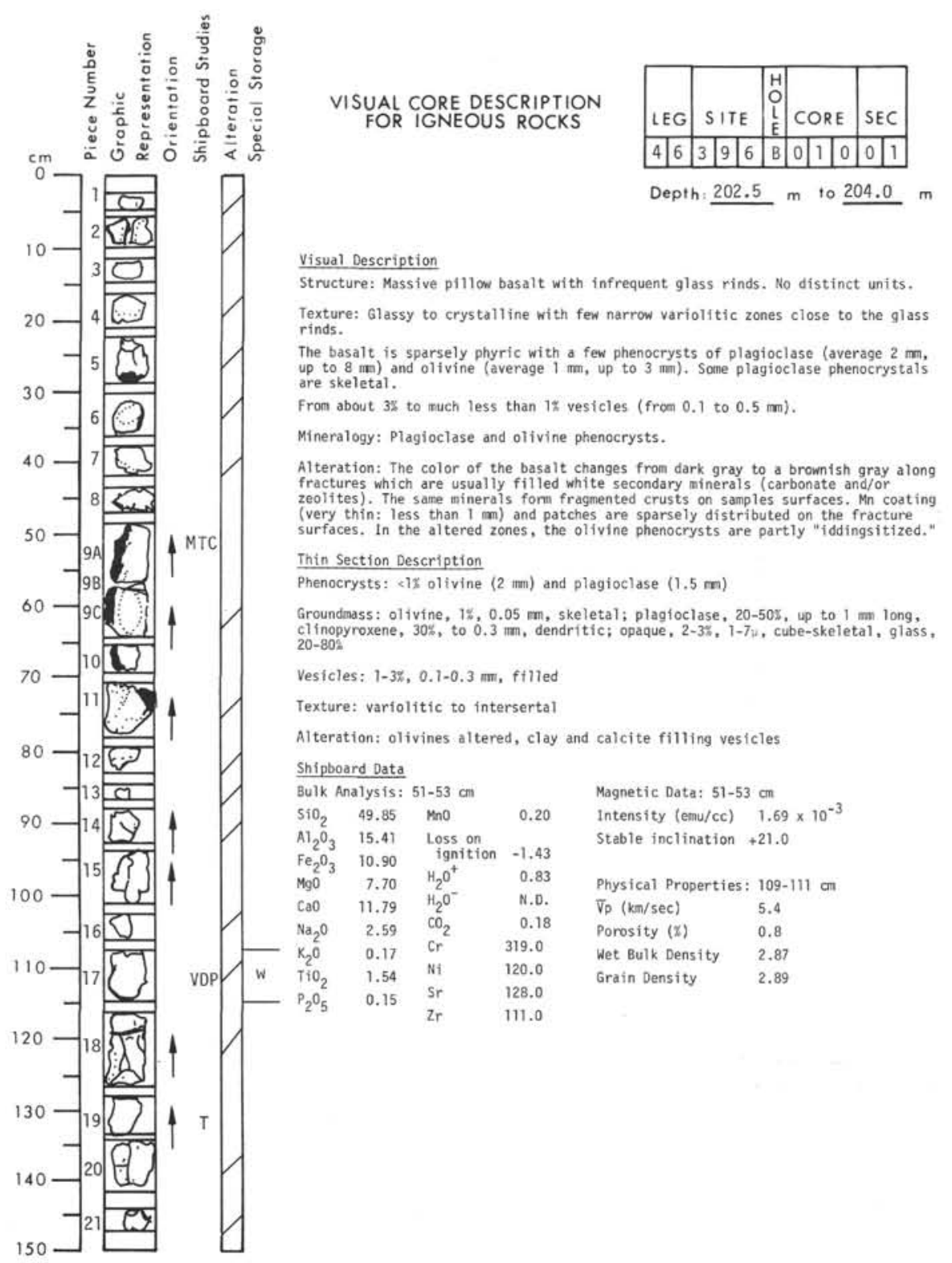




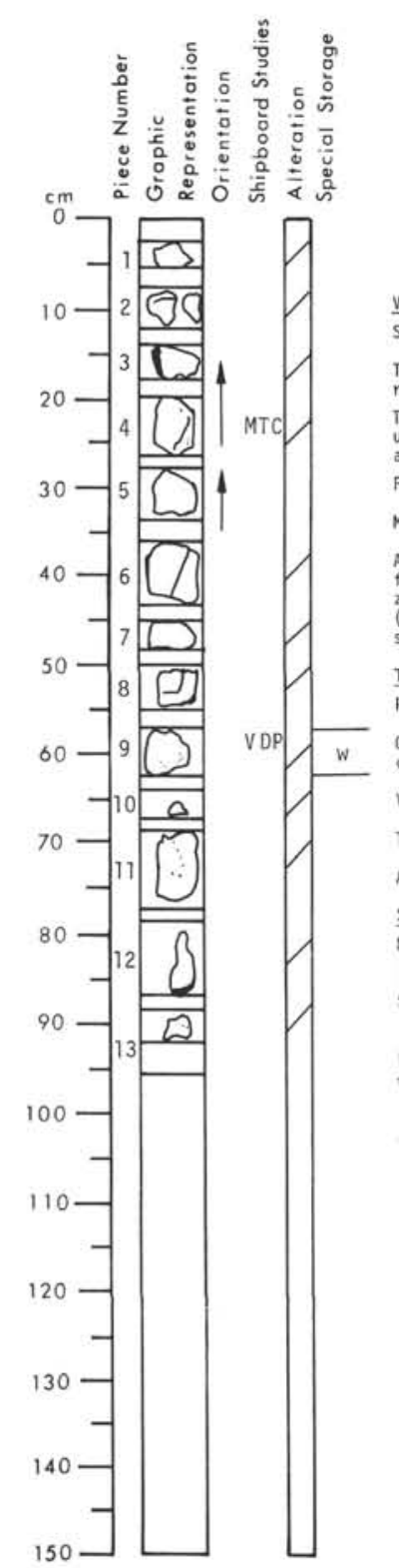

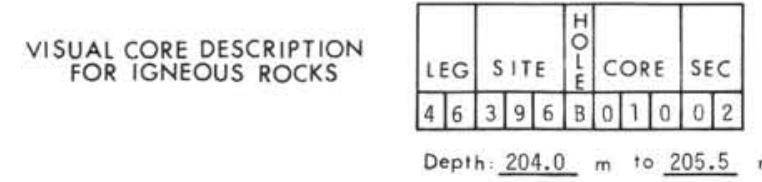

Visual Description

Structure: Massive pillow basalt with infrequent glass rinds. No distinct units. Texture: Glassy to crystalline with few narrom variolitic zones close to the glass The basalt is sparsely phyric with a few phenocrysts of plagioclase (average $2 \mathrm{~mm}$ up to $8 \mathrm{~min}$ ) and olivine (average $1 \mathrm{~mm}$, up to $3 \mathrm{~mm}$ ). Some phage From about $3 \mathrm{H}$ to much less than $1 \mathrm{~K}$ vesicles (fran 0.1 to $0.5 \mathrm{~mm}$ ). Mineralogy: Plagioclase and olivine phenocrysts.

Alteration: The color of the basalt changes from dark gray to a brownish gray along
fractures which are usually filled white secondary minerals (Carbonate and/or a Thin Section Description

Phenocrysts: <1\% olivine (1 $\mathrm{mm})$ and plagioclase $(0.4 \mathrm{mil}$

Groundrass: olivine, <1\%, $0.05 \mathrm{~mm}$, skeletal; plagioclase, $30 \%, 0.2 \mathrm{~mm}$, skeletal;

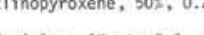

Texture: variolitic-intersertal

Alteration: olivine altered, glass altered to clay, calcite yein

Shipboard Data

Magnetic Data: $21-23$ a

Intensity (emu/cc) $4.01 \times 10^{-4}$

stable inclination +19.0 ?

Physical Properties: $59-61 \mathrm{~cm}$

$\nabla_{p}(\mathrm{~km} / \mathrm{sec}) \quad 5.4$

Porosity (I)

0.8

Net Bulk Density 2.87

Grain Density $\quad 2.89$

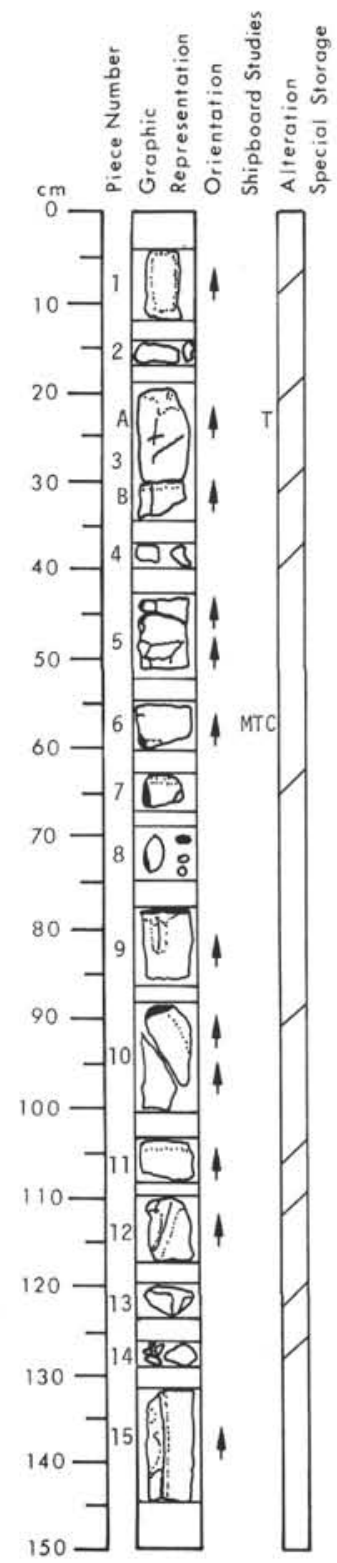

\section{VISUAL CORE DESCRIPTION
FOR IGNEOUS ROCKS}

(1)

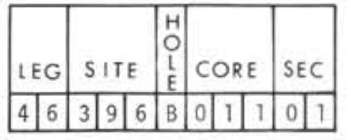

Depth: $202.5 \mathrm{~m}$ to $212.0 \mathrm{~m}$

Visual Description

Structure: Pillow basalt with infrequent glass rinds. No distinct units.

Texture: 6lassy to crystalline with few narrow variolitic zones close to the glass The basalt is sparsely phyric with a few phenocrysts of plagioclase (average $2 \mathrm{~mm}$ are skeletal.

Very few (cil1) vesicles in the upper portion, while about 18 vesicles $(0.1-0.5 \mathrm{~mm})$
in the lower portion. Mineralogy: Plagioclase and olivine phenocrysts.

Alteration: The color of the basalt changes from dark gray to a brownish gray along
fractures which are usually filled white secondary minerals (carbonate and (ittes). The same minerals form fragnented crusts on sarnples surfaces. Mn coating (very thin: less than $1 \mathrm{~mm}$ ) and patches are sparsely distributed on the fracture
surfaces. In the altered zones, the olivine phenocrysts are partly "iddingsitized," Thin Section Description

Phenocrysts: c12 olivine $(.75 \mathrm{~m})$ and plagioclase $(1 \mathrm{~m})$

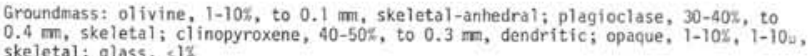

Vesicles: $1-2 \%$, mostly open

Texture: variolitic-intersertal

Alteration: phenocryst-olivine altered; clay, calcite, and zeolites in voids Shipboard Data Bulk Analysis: $56-58 \mathrm{~cm}$ $\mathrm{SiO}_{2} \quad 49.82 \quad \mathrm{MnO}$ 0.20 Intensity (emu/cc) $\quad 1.25 \times 10^{-3}$ Stable inclination +5.0 sgention $-1,390$ $\begin{array}{llll}7.77 & \text { H O } & 0.83 \\ \mathrm{CaO} & 11.79 & \text { H O } & \text { N.D. }\end{array}$ $\begin{array}{lllll}\mathrm{Na}_{2} \mathrm{O} & 2.59 & \mathrm{CO} & 0.17\end{array}$ $\begin{array}{llll}\mathrm{K}_{2} \mathrm{O} & 0.20 & \mathrm{Cr} & 310.0\end{array}$ $\begin{array}{llll}\mathrm{TiO}_{2} & 1.54 & \mathrm{Ni} & 122.0\end{array}$ $\begin{array}{llll}\mathrm{P}_{2} \mathrm{O}_{5} & 0.14 & \mathrm{Sr} & 126.0 \\ & & \mathrm{Zr} & 103.0\end{array}$ 


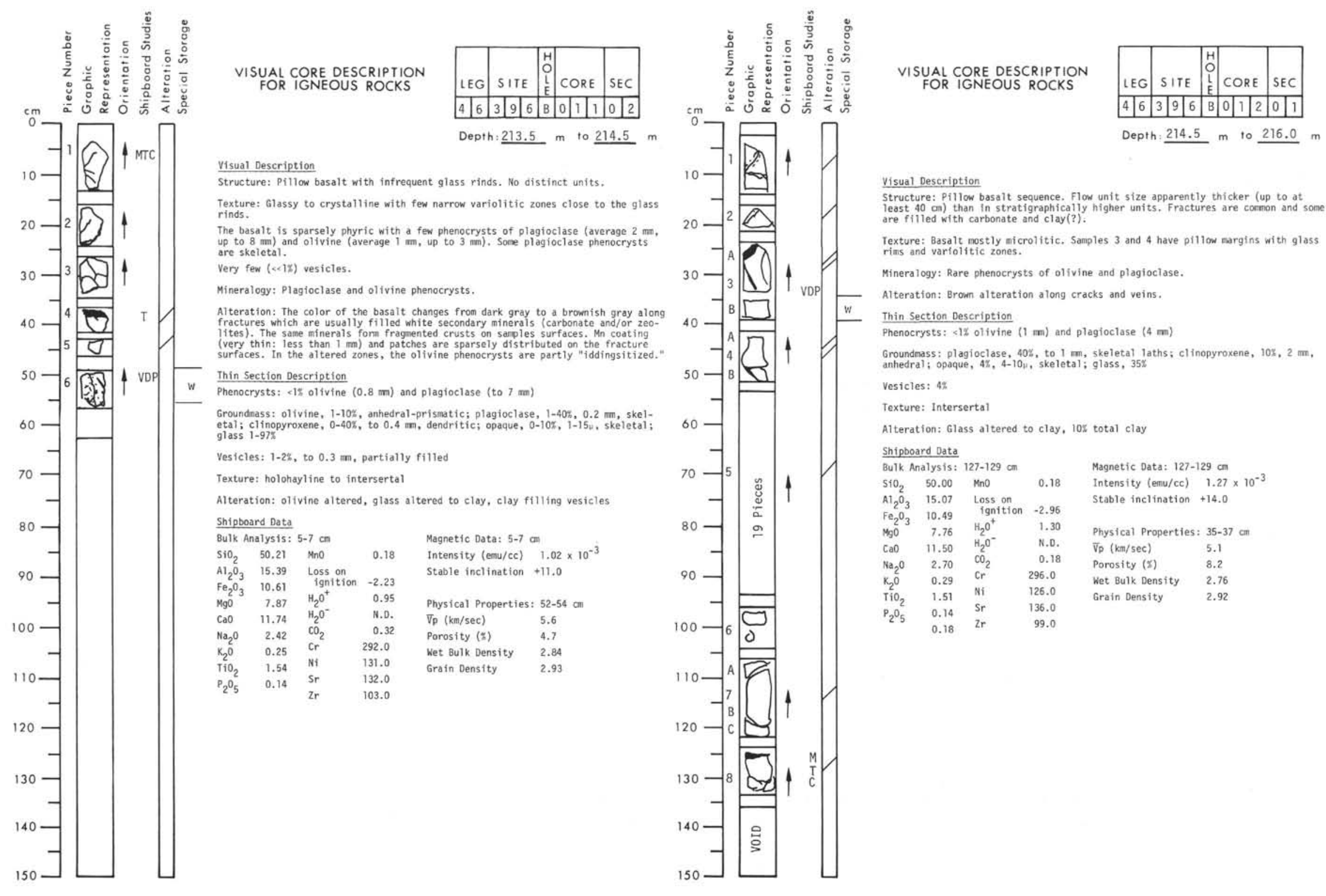




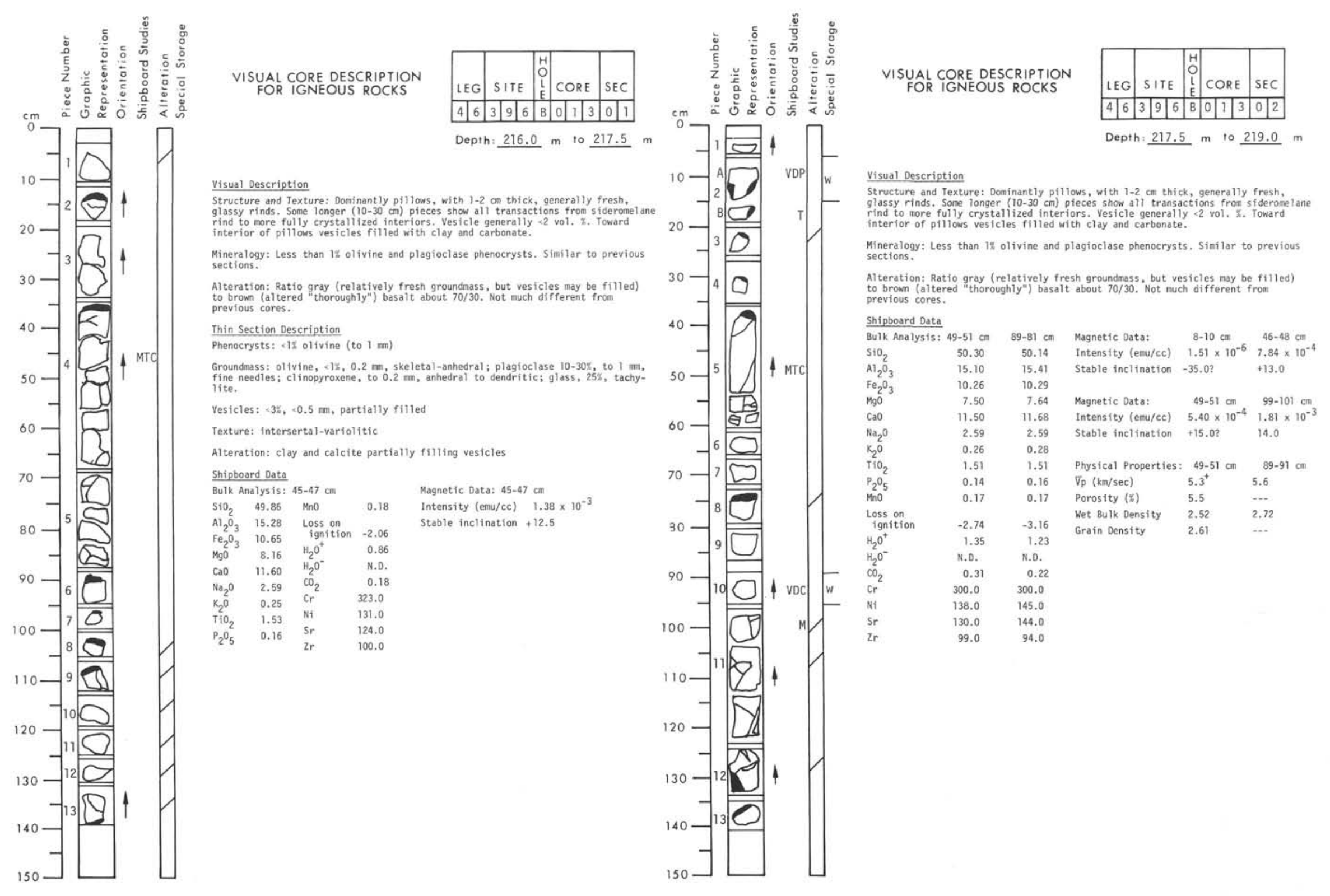




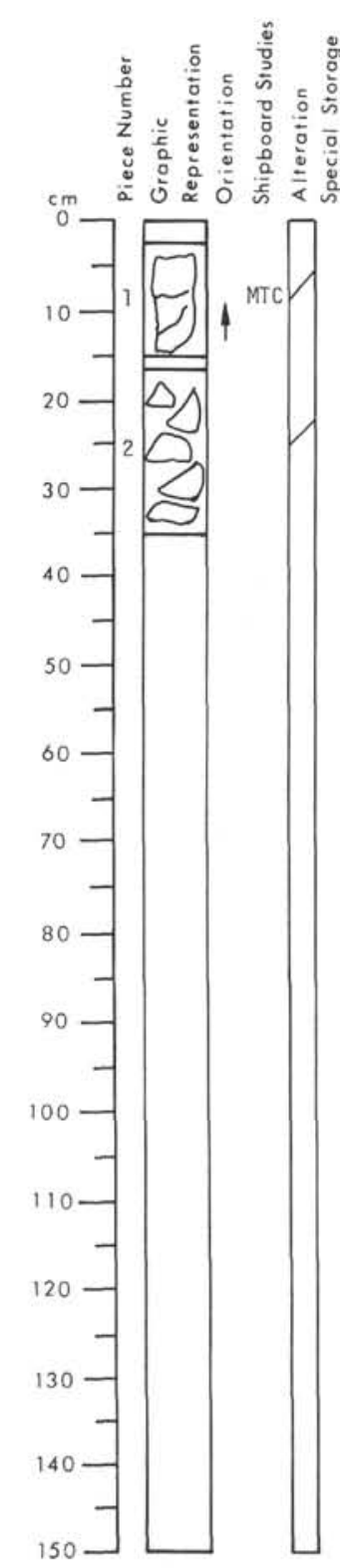

VISUAL CORE DESCRIPTION FOR IGNEOUS ROCKS

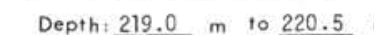

Visual Description

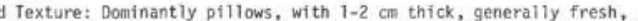
glassy rinds. Some fonger $(10-30 \mathrm{cin})$ pieces show all transactions from siderometa nterior of pillows vesicles filled with clay and carbonate.

Mineralogy: Less than 1\% olivine and plagioclase phenocrysts. Similar to previous

Alteration: Ratio gray (relatively fresh groundasass, but vesicles may be filled) previous cores.

Thin Section Description

1\% 01fivine $(1-2 \mathrm{~mm})$ and plagioclase $(-1 \mathrm{~m})$

Groundmass: olivine, $2 \%, 0.2 \mathrm{~mm}$, anhedral, plagioclase, 60\%, clinopyroxene,
dendrites in mesostasis; glass, $30 \%$, tachylite

Vesicles: $-2 x, 0.5 \mathrm{~mm}$, partially filled

exture: intersertal

Alteration: clay replacing glass and filling vesicles, 1 is caicite Shipboard Data

Bulk Analysis: 4-6 cm

$\mathrm{SiO}_{2} \quad 50.11 \quad \mathrm{MnO}$

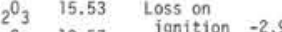

Magnetic Data: 4-6 cir

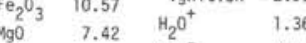

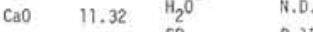

$\begin{array}{llll}\mathrm{Na}_{2} \mathrm{O} & 2.79 & \mathrm{CO}_{2} & 0.15 \\ \mathrm{~K}_{2} \mathrm{O} & 0.27 & \mathrm{Cr}^{2} & 297.0\end{array}$

$\begin{array}{llll}\mathrm{K}_{2} \mathrm{O} & 0.27 & \mathrm{Cr} & 297.0\end{array}$

$\mathrm{TiO}_{2} \quad 1.67 \quad \mathrm{Ni}-156.0$

$\begin{array}{llll}P_{2} 0_{5} & 0.15 & \mathrm{Sr} & 146.0 \\ & \mathrm{Zr} & 126.0\end{array}$
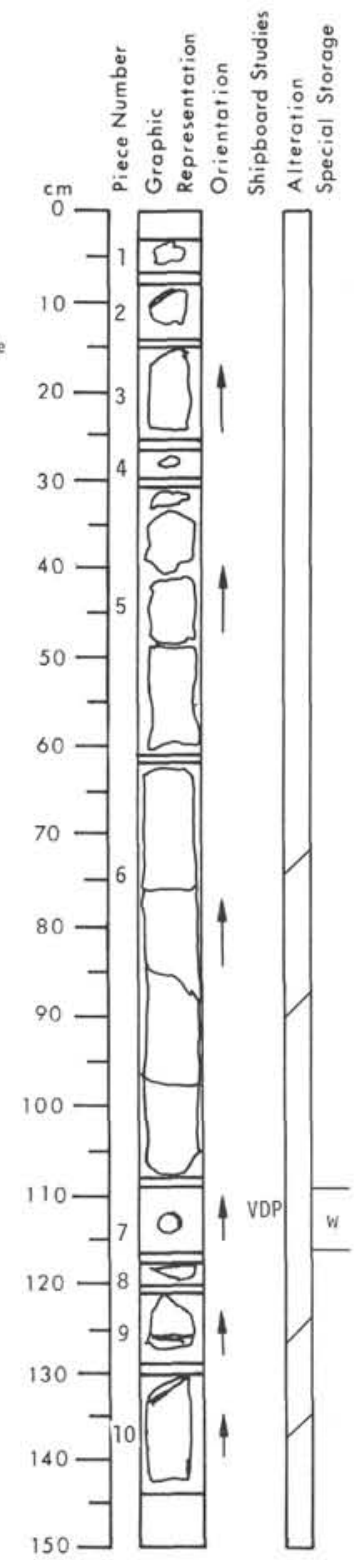

\section{VISUAL CORE DESCRIPTION
FOR IGNEOUS ROCKS}

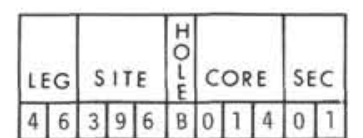

Depth: $225.5 \mathrm{~m}$ to 227.0

Visual Description

Lithology: Massive basalt similar to Core 13. Vesicles are filled. Plagioclase and

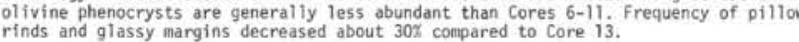
Mineralogy: 01ivine and plagioclase phenocrysts present but abundance is down fron

Alteration: Width and abundance of brown alteration halos around cracks have decreased. Groundnoss alteration (primarify vesicle filtings) is far more pervasive. more advanced. Ratio of fresh to altered material $80: 20$.

Shipboard Data

Properties: $110-112 \mathrm{~cm}$

Tp $(\mathrm{km} / \mathrm{sec}) \quad 5.5$

Wet Bulk Density $\quad 2.70$

Grain Density 2.78 


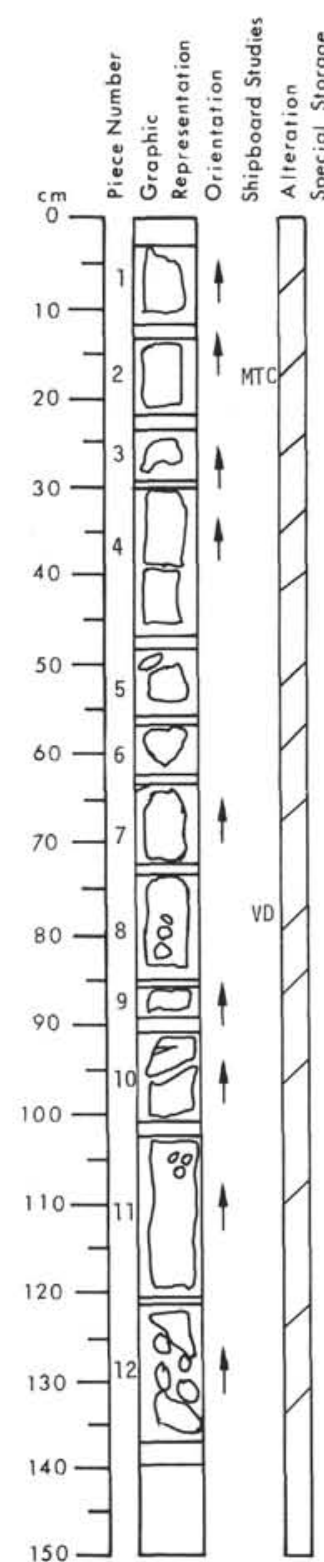

\section{VISUAL CORE DESCRIPTION
FOR IGNEOUS ROCKS}

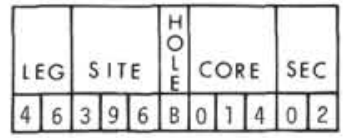

Visual Description

Lithology: Massive basalt similar to Core 13. Vesicles are filled. Plagioclase and rinds and glassy margins decreased a bout $30 \%$ conpared to core 13 . Frequency of pillo Mineralogy: 01ivine and plagioclase phenocrysts present but abundance is down from
above. 0livines are generally more pddingsitized than cores $6-11$. Alteration: width and abundance of brown alteration halos around cracks have deFractures are typically filled but thickness $<2 \mathrm{~mm}$. Palagonitization of glass is Fore advanced.

Thin Section Description

enocrysts: <1\% plagioclase (1 mm)

Groundrass: olfvine, $2 x, 0.1 \mathrm{~mm}$, skeletal; plagioclase 25\%, radfating bundles of Vesicles: 1-2\%, filled

Texture: spherulitic

Alteration: local clay replacing glass, vesicles filled by clay Shipboard Data

Ilk Analysis: $17-19 \mathrm{~cm}-$ Magnetic Data: $17-19 \mathrm{~cm}$

$\mathrm{SlO}_{2} \quad 49.70 \quad \mathrm{MnO} \quad 0.17$

$\mathrm{Al}_{2} \mathrm{O}_{3} \quad 15.30$ Loss on $\quad$ Stable inclination -77 .

$\mathrm{Ce}_{2} \mathrm{O}_{3} \quad 10.81 \quad$ ignition -2.54

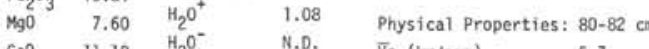

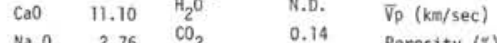

$\begin{array}{llllll}\mathrm{Na}_{2} \mathrm{O} & 2.76 & \mathrm{CO}_{2} & 2.14 & \text { Porosity (x) } & -. . \\ \mathrm{K}_{2} \mathrm{O} & 0.29 & \mathrm{Cr} & 297.0 & \text { Wet Bulk Density } & 2.74\end{array}$

Grain Density

$\begin{array}{llll}\mathrm{P}_{2} \mathrm{O}_{5} & 0.16 & \mathrm{Sr} & 143.0 \\ & \mathrm{Zr} & 129.0\end{array}$

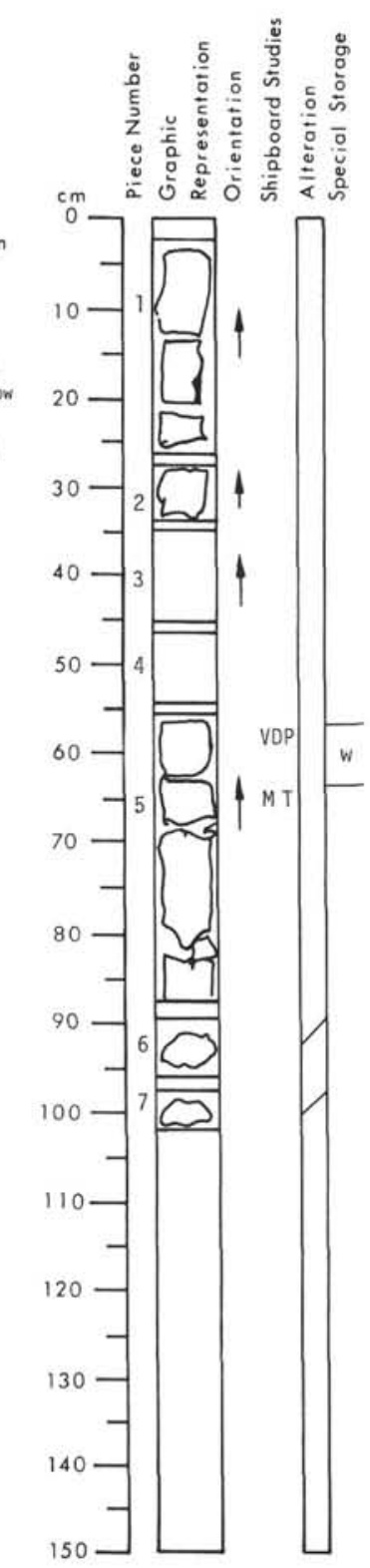

VISUAL CORE DESCRIPTION FOR IGNEOUS ROCKS

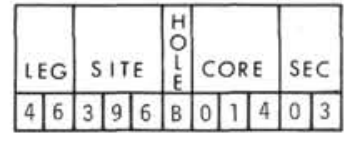

Depth. $228.5 \mathrm{~m}$ to $230.0 \mathrm{~m}$

Visual Description

fithology: Massive basalt similar to Core 13. Vesicles are filled. Plagiociase and rinds and glassy margins decreased about 30: compared to core 13 .

Mineralogy: 01ivine and plagioclase phenocrysts present but abundance is down from Width and abundance of brown al fractures are typically filled but thickness 22 mat. Palagonitization of glass is . Ratio of fresh to altered material $80: 20$.

Thin Section Description

Phenocrysts: <18 plagioclase $(1.5 \mathrm{~m})$

Groundmass: 01 ivine, $<1 \%,<2 \mathrm{~mm}$, granular; plagioclase, $355,-1 \mathrm{~mm}$ needles; clino-
pyroxene, 30\%, dendritic; glass

esicles: 1-2\% mostiy filled

Texture: intersertal to intergranular

Alteration: clay replacing mesostasis, clay filling vesicles

Shipboard Data

Magnetic Data: $66-68 \mathrm{~cm}$

intesnity (eru/cc) $1.79 \times 10^{-3}$

Stable inclination -73.0

Physical Properties: 58-60 cm

$\operatorname{Vp}(\mathrm{km} / \mathrm{sec}) \quad 5.8$

Porosity (z) $\quad 4.6$

$\begin{array}{ll}\text { Wet Bulk Density } & 2.72 \\ \text { Grain Density } & 2.81\end{array}$ 

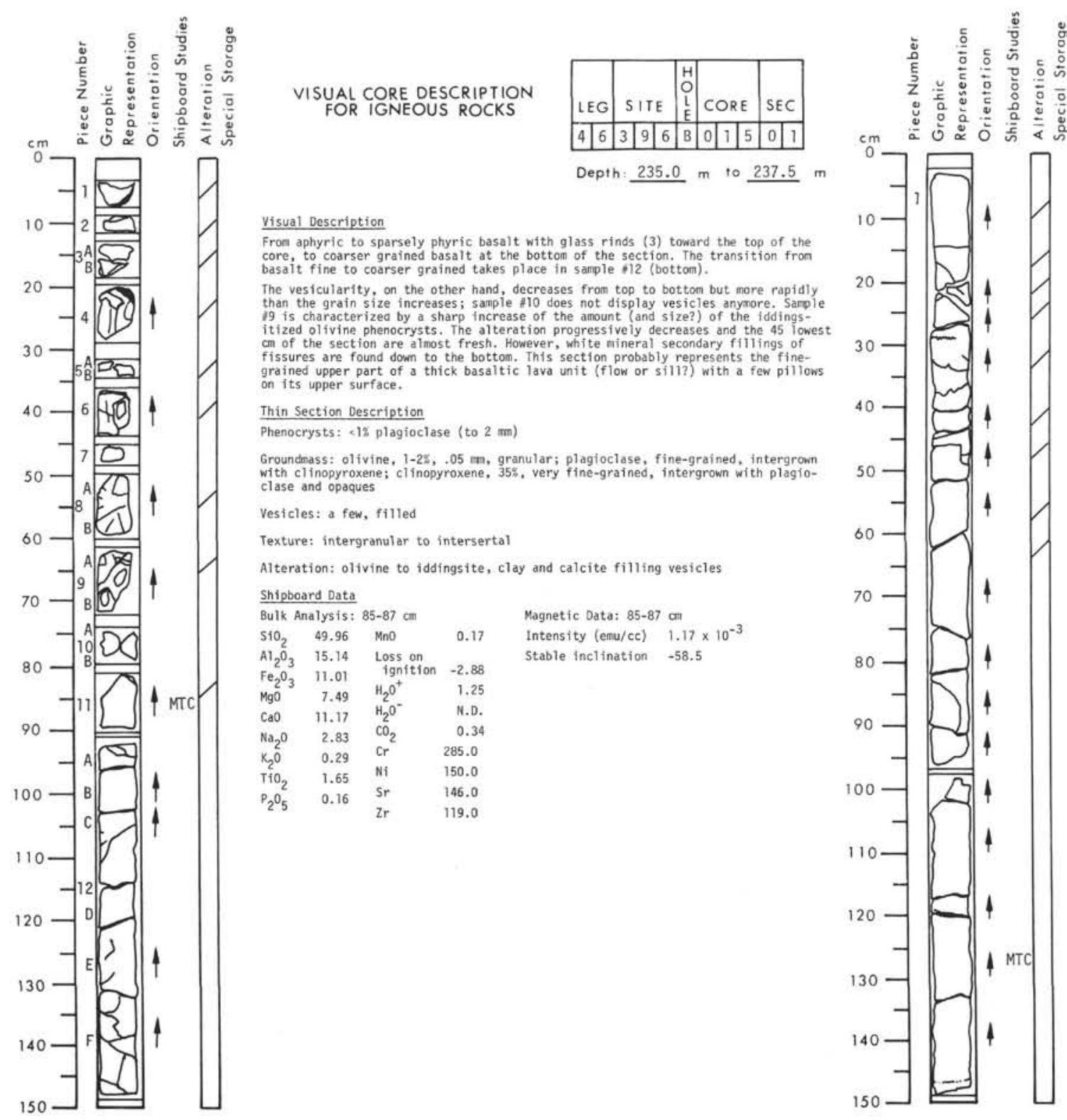

\section{VISUAL CORE DESCRIPTION FOR IGNEOUS ROCKS

\begin{tabular}{|c|c|c|c|}
\hline LEG & SITE & CORE & SEC \\
\hline \begin{tabular}{|l|l|}
4 & 6 \\
\end{tabular} & \begin{tabular}{l|l|l|l}
3 & 9 & 6 \\
\end{tabular} & 0.15 & 02 \\
\hline
\end{tabular}

Visual Description

Fine- to medium-grained basalt, sparsely phyric, with $1-2$ mp plagioclase phenocrysts
(auch less than 12 ), Grain sige plagioclase laths greater than $1 \mathrm{~mm}$.

Top third of section altered to grayish brown with occasional crosscutting carbonate of section has light brown alteration rim at base (about $1 \mathrm{~cm}$ thick) Part of large flow sill which occupies most of core 15 , Sections 1 to 5. Thin Section Description

II plagioclase (to $2 \mathrm{~min}$ )

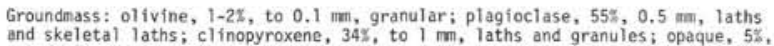
and skeletal laths; clinopyroxer.

Vesicles: filled

Texture: intergranular

Alteration: clay filling vesicles

Shipboard Data

Bulk Analaysis: 129-131 cm

$\mathrm{SiO}_{2} \quad 49.90 \quad \mathrm{MnO}$

0.17

$\mathrm{Al}_{2} \mathrm{O}_{3} \quad 14.98$ Loss on

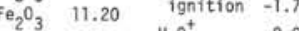

$\begin{array}{llll} & 7.93 & \mathrm{H}_{2} \mathrm{O}^{\mathrm{O}}- & 0.90\end{array}$

$\begin{array}{llll} & 11.01 & \mathrm{H}_{2} \mathrm{O}^{-} & \text {N.O. }\end{array}$

$\begin{array}{llll}\mathrm{Na}_{2} \mathrm{O} & 2.63 & \mathrm{CO}_{2} & 0.13 \\ \mathrm{Cr}^{2} & 0.14 & \mathrm{Cr} & 266.0\end{array}$

$\begin{array}{llll}\mathrm{k}_{2} \mathrm{O} & 0.14 & \mathrm{Cr} & 266.0 \\ \mathrm{C}_{\mathrm{i}} & 1.63 & \mathrm{Ni} & 119.0\end{array}$

$\begin{array}{llll}\mathrm{TiO}_{2} & 1.63 & \mathrm{Ni} & 119.0 \\ \mathrm{P}_{2} \mathrm{O}_{5} & 0.17 & \mathrm{Sr} & 142.0\end{array}$

Magnetic Data: 129-131 Cm

Intensity (enu/cc) $2.57 \times 10^{-3}$

Stable inclination -65.0

$\mathrm{Fe}_{2} \mathrm{O}_{3} \quad 11.01$ ignition -2.88

$\begin{array}{rrrr}\mathrm{MgO} & 7.49 & \mathrm{H}_{2} \mathrm{O}^{-} & 1.25 \\ \mathrm{CaO} & 11.17 & \mathrm{H}_{2} \mathrm{O}^{-} & \text {N.D. } \\ & 2.83 & \mathrm{C}_{2} & \end{array}$

$\begin{array}{llll}\mathrm{Na}_{2} \mathrm{O} & 2.83 & \mathrm{CO}_{2} & 0.34\end{array}$

$\begin{array}{lllllll}\mathrm{K}_{2} \mathrm{O} & 0.29 & \mathrm{Hr} & 285.0\end{array}$

$\begin{array}{llll}\mathrm{P}_{2} \mathrm{O}_{5} & 0.16 & \mathrm{Sr} & 146.0\end{array}$ 


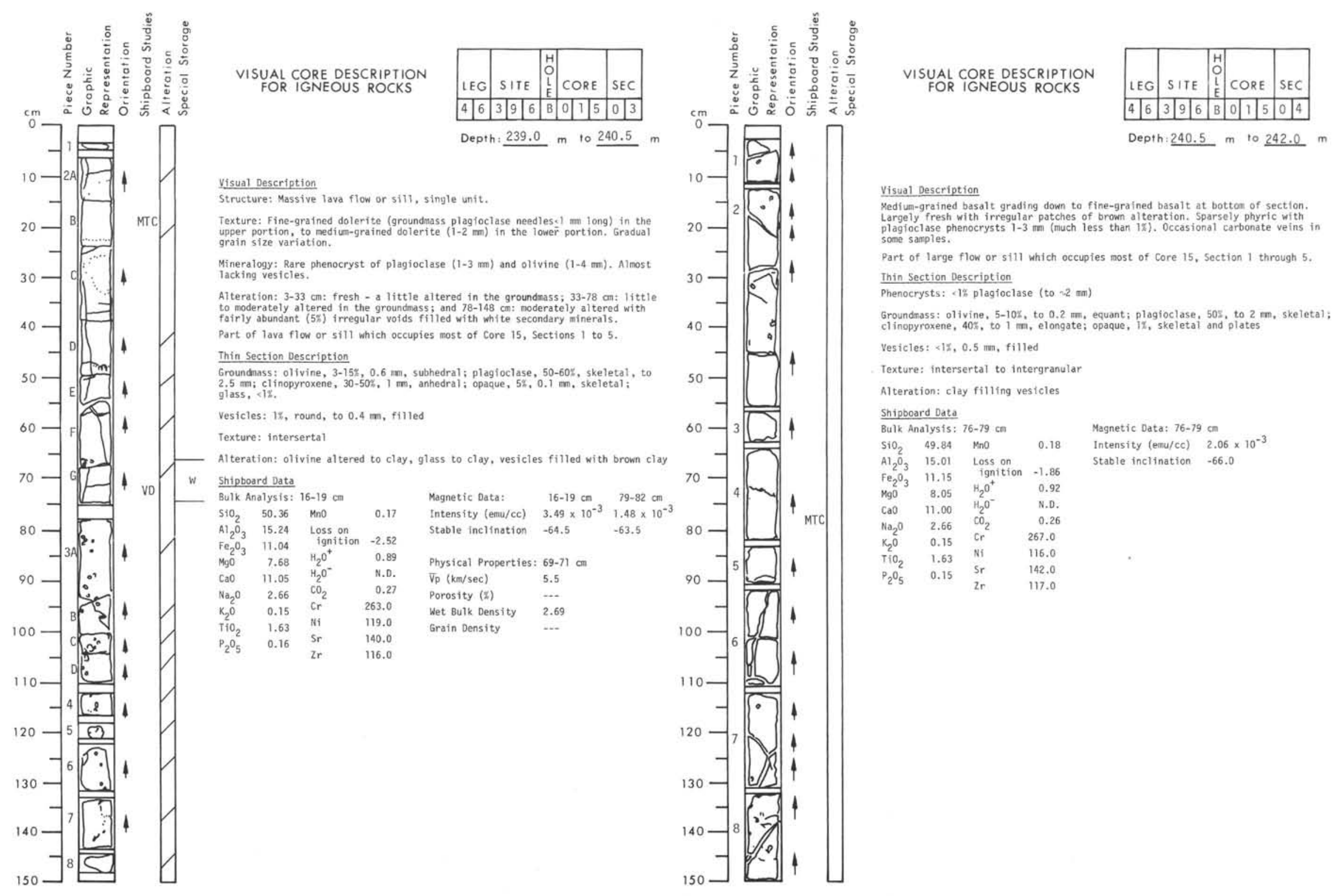




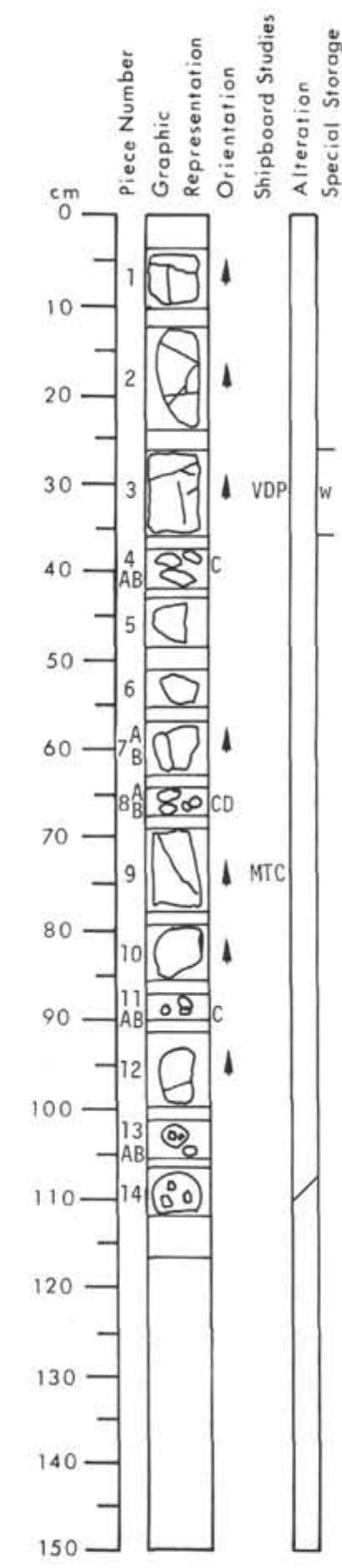

\section{VISUAL CORE DESCRIPTION
FOR IGNEOUS ROCKS}

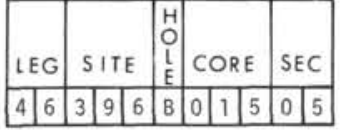

Visual Description

Structure: Pieces 11 to 12 (3-100 cm) - Part of single unit of massive aphyric or

pieces $\$ 13$ and 14 - Porphyritic basalt.

Texture: Pieces $t 1$ to $12-$ Fine-grained basalt (no variation of groundnass grain
size). Aphyric to sparsely phyric. Pieces 613 and 14 - Porphyritic basalt.

Mineralogy: Pieces $i 1$ to 12 - Rare phenocryst of 017 vine $(1-2 \mathrm{~mm})$ and plagioclase Rare vesicles often filled with secondary minerals piece 13 . Plagioclase pheno crysts, 10-15\%, 1-3 m; olivine phenocrysts $5 \%, 1-3 \mathrm{~mm}$. Piece 014 - Plagioclase
phenocrysts $10-15 \%, 2-5 \mathrm{~mm}$; olivine phenocrysts $5 \%, 1-3 \mathrm{~mm} ;$ rare vestcles $(0.5 \mathrm{~mm})$ Aiteration: Pieces 41 to 12 - Velateration in the groundrass throughout. Uncommon erate to extensive alteration - Slight atteration of Shipboard Data

Bulk Analysis: $70-73 \mathrm{~cm} \quad$ Magnetic Data: $70-73 \mathrm{~cm}$

$50_{2} \quad 49.73 \quad \mathrm{MnO} \quad 0.18 \quad$ Intensity (emu/cc) $5.00 \times 10^{-3}$

$\mathrm{Al}_{2} \mathrm{O}_{3} \quad 15.11$ Loss on $\quad$ Stable inclination -69.0

$\mathrm{Fe}_{2} \mathrm{O}_{3} \quad 11.23 \quad$ ignition -2.41

mgo $8.06 \quad 2^{-}$Physical Properties: $30-32 \mathrm{~cm}$

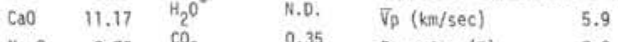

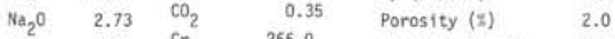

$\mathrm{K}_{2} \mathrm{O} \quad 0.32$ Cr Met Bulk Density 2.74

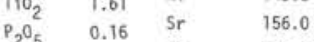

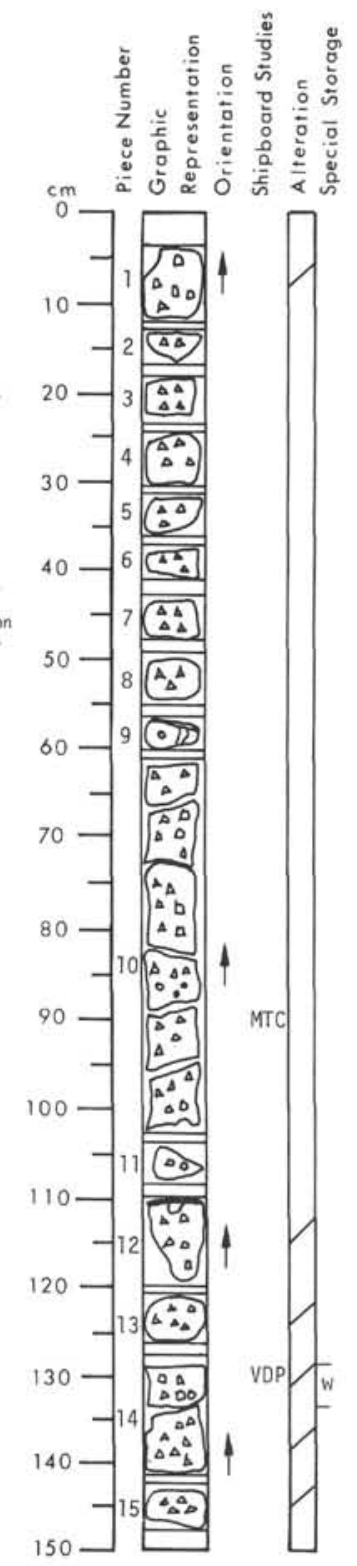

VISUAL CORE DESCRIPTION

FOR IGNEOUS ROCKS

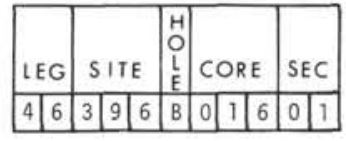

Depth: $244.5 \mathrm{~m}$ to $246.0 \mathrm{~m}$

\section{Visual Description}

Structure: Uniform basalt - no visible pillows, no variation in texture.

Texture: Ten to twenty percent phenocrysts - microlitic groundmass.

Mineralogy: 01 ivine and plagioclase phenocrysts. Plagioclase/0livine $-3 / 1$. No
systematic variation in phenocrysts. Small areas with few phenocrysts - plece to poorer in phenocrysts.

Alteration: 1) Brown siteration of basalt. 2) Vesicle filling with gray clay,

Thin Section Description

Phenocrysts: olivine, $5 \%$, to $4 \mathrm{~mm}$, plagioclase, 20\%, to $4 \mathrm{~mm}$, euhedral-skeletal

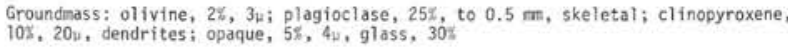

Yesicles: 3 3e

Texture: porphyritic-interserta

Alteration: vesicles clay lined, glass altered

Shipboard Data

Bulk Analysis: $83-85 \mathrm{~cm} \quad$ Magnetic Data: $83-85 \mathrm{~cm}$

$\begin{array}{llllll}\mathrm{SiO}_{2} & 49.39 & \mathrm{MnO} & 0.16 & \text { Intensity (emu/ce) } & 2.41 \times 10^{-3}\end{array}$

$\mathrm{Al}_{2} \mathrm{O}_{3} \quad 16.88$ Loss on $\quad$ Stable inclination -10.8

Fe ignition -1.79

$\begin{array}{llll}\mathrm{MgO}_{9} & -7.25 & \mathrm{H}_{2} \mathrm{O}^{+} & 1.10\end{array}$

$\mathrm{Na}_{2} \mathrm{O} \quad 2.42 \quad \mathrm{CO}_{2}$

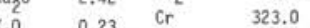

$\begin{array}{llll}\mathrm{NO}_{2} & 1.20 & \mathrm{Ni} & 129.0\end{array}$

Physical Properties: 130-132 cm

$\bar{\nabla} p(\mathrm{~km} / \mathrm{sec})$

4.7

$\begin{array}{llll}\mathrm{P}_{2} \mathrm{O}_{5} & 0.12 & \mathrm{Sr} & \mathrm{Zr}\end{array}$ 


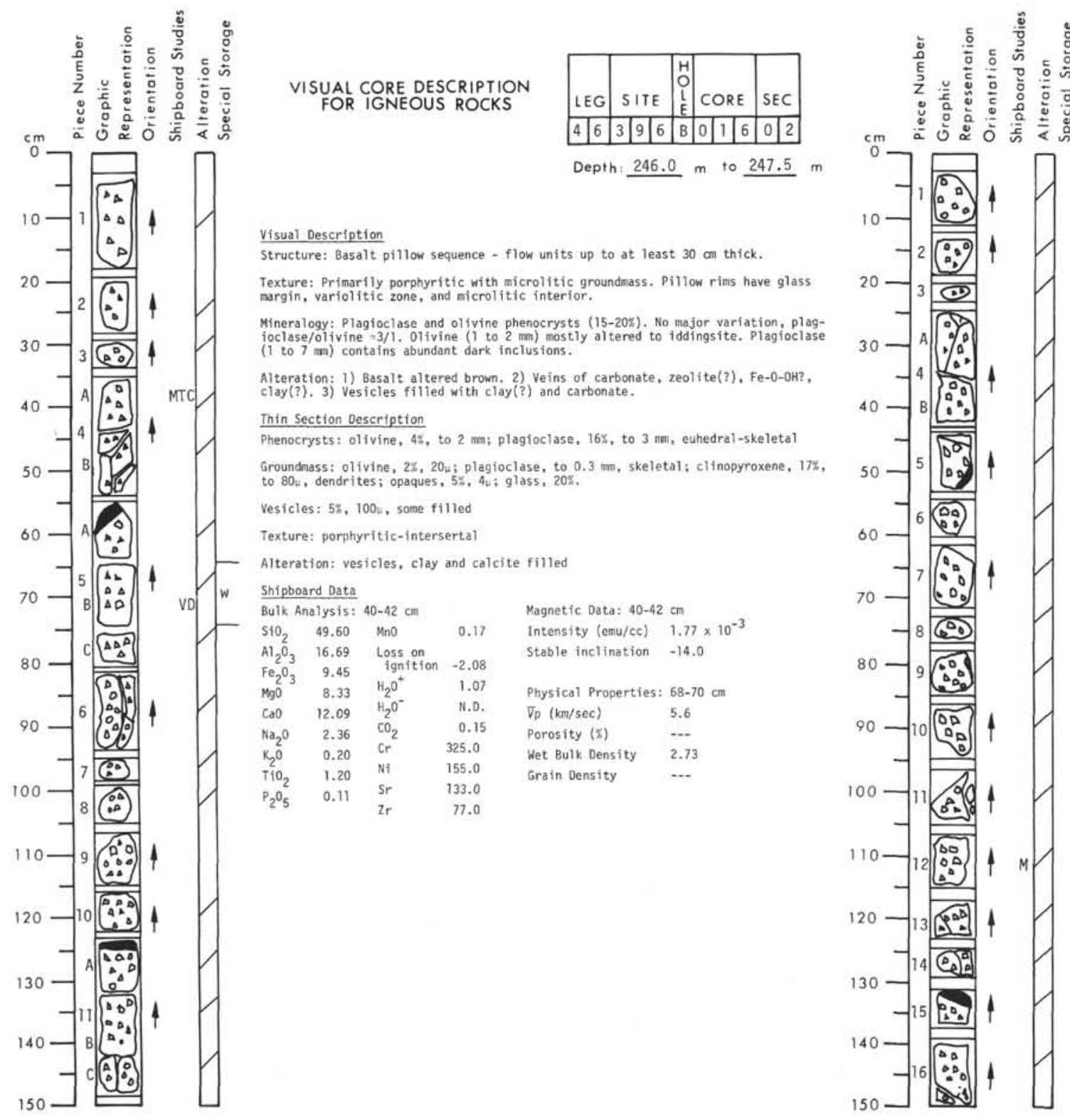

VISUAL CORE DESCRIPTION
FOR IGNEOUS ROCKS

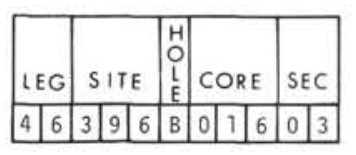

Depth: $247.5 \mathrm{~m}$ to $\underline{249.0} \mathrm{~m}$

Visual Description

Structure: Basalt pillow sequence - flow units up to at least 30 on thick.

Texture: Primarily porphyritic with microlitic grounchass. Pillow rims have glass hargin, variolitic zone, and microlitic interior.

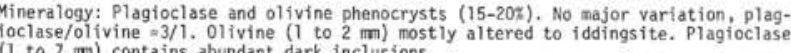

Alteration: 1) Basalt altered brom. 2) Veins of carbonate, zeolite(?), Fe-0-0H?,

Shipboard Data

Magnetic Data: $109-111 \mathrm{~cm}$

Intensity (emu/cc) $\quad 3.68 \times 10^{-3}$

Stable inclination $\quad-11.0$ 

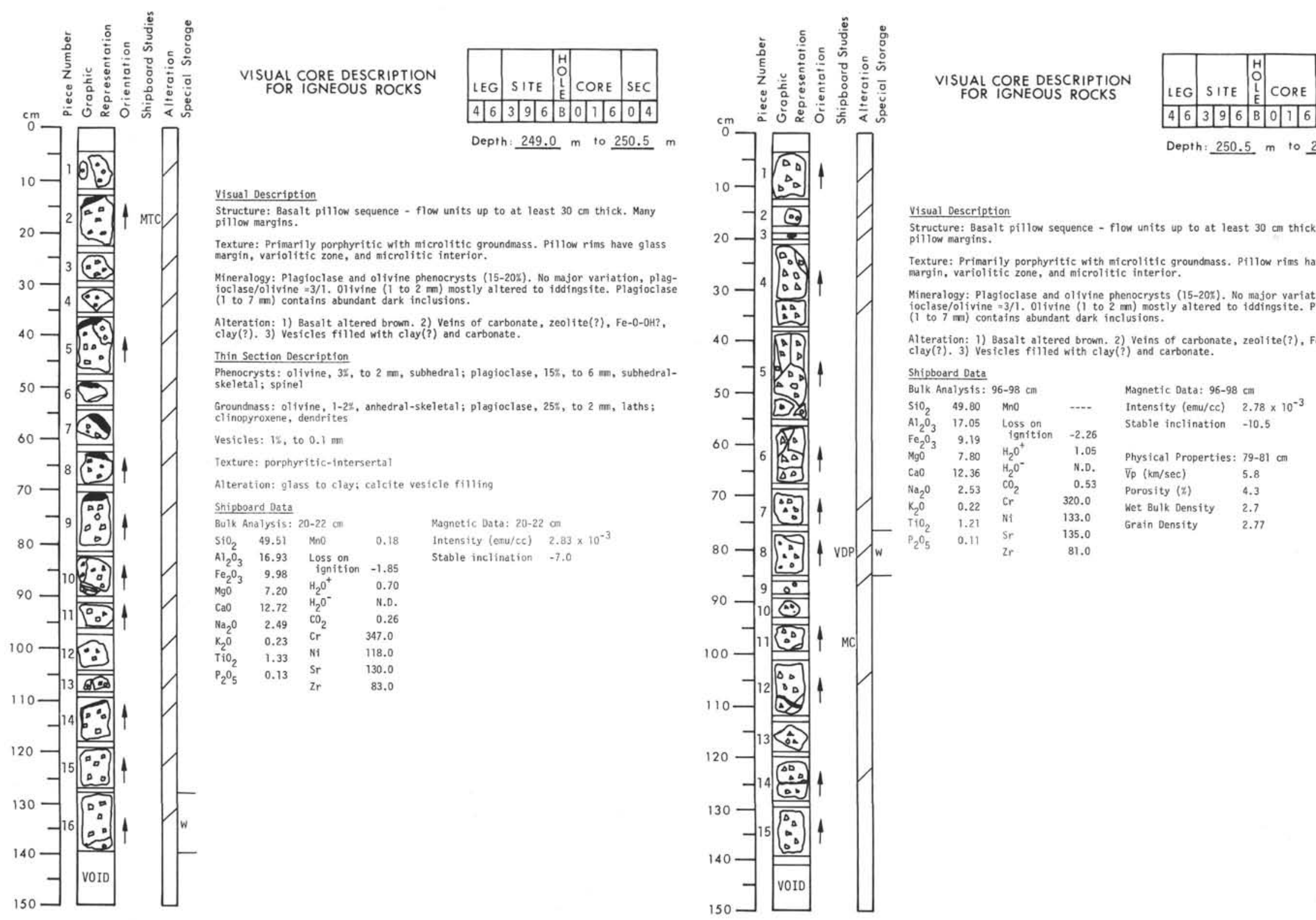
Visual Description

VISUAL CORE DESCRIPTION
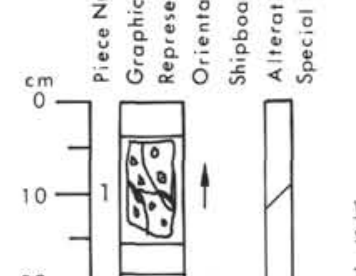

Structure: Basalt pillow sequence with interbedded well-1ithified carbonate ooze. Texture: Limestone - dense, fine-grained. Basalt - primarily microlitic. Pillow
margins have glassy rim and variolitic zone with microlitic interior. Basalt is porphyritic

Mineralogy: Plagioclase and olivine phyric $-20 \%$ phenocrysts. Plagioclase/01ivine
$=2.5 / 1$. Olivine 1 to 2 mn, plagioclase 1 to 5 m. Plagioclase with abundant dark

Aiteration: 1) Basalt altered brown along cracks. 2) Vesicles filled with dark clay
zeolites (?) and carbonate. 3) 01ivine altered to iddingsite, 4) veins filled with carbonate and pink zeolite (?

Thin Section Description

Phenocrysts: olfvine, $2 \%$, to $2 \mathrm{~m}$; plagioclase, $15 \%$ to $5 \mathrm{~mm}$, euhedral to rounded.

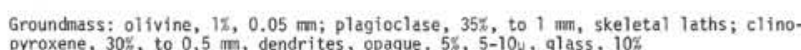
Vesicles: 25, to $1 \mathrm{~mm}$

Texture: porphyritic-intersertal

Alteration: glass altering to clay

Shipboard Data

Bulk Analysis: $132-134 \mathrm{~cm}$

$\mathrm{SiO}_{2} \quad 49.75 \quad \mathrm{MnO}$

$\begin{array}{lll} & \\ \text { ignition } & -2.49\end{array}$

$\begin{array}{llll}\mathrm{MgO}_{9} \mathrm{O} & 7.78 & \mathrm{H}_{2} \mathrm{O}^{+} & 0.93\end{array}$

$\begin{array}{llll}\text { Ca0 } & 12.38 & \mathrm{H}_{2} \mathrm{O}^{-} & \text {N.D. } \\ & \mathrm{CO}_{2} & 0.58\end{array}$

$\begin{array}{llll}\mathrm{Na}_{2} \mathrm{O} & 2.39 & \mathrm{CO}_{2} & 0.58 \\ & \mathrm{Cr}_{2} & 335.0\end{array}$

$\begin{array}{llll}\mathrm{K}_{2} \mathrm{O} & 0.22 & \mathrm{Cr} & 335.0 \\ \mathrm{ri} & \mathrm{Ni} & 144.0\end{array}$

$\begin{array}{llll}\mathrm{TiO}_{2} & 1.21 & \mathrm{Nr} & 144.0 \\ \mathrm{P}_{2} \mathrm{O}_{5} & 0.11 & \mathrm{Sr} & 142.0\end{array}$

Magnetíc Data: $132-134 \mathrm{~cm}$ $2.11 \times 10^{-3}$

table inclination -7.0

Physical Properties: $69-71$ an

Vp $(\mathrm{km} / \mathrm{sec})$

Wet Bulk Density 2.64

Grain Density

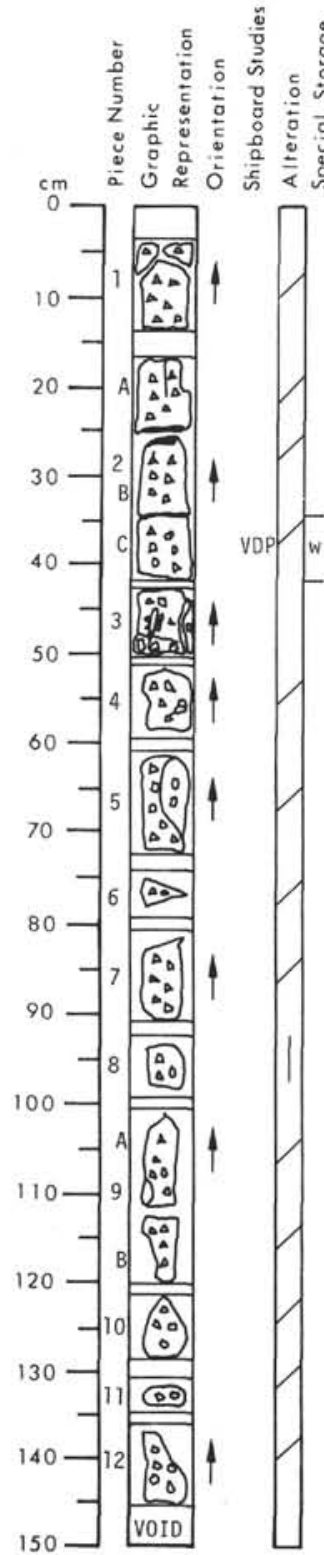

VISUAL CORE DESCRIPTION
FOR IGNEOUS ROCKS

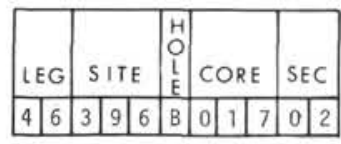

Depth: $269.0 \mathrm{~m}$ to $270.5 \mathrm{~m}$

Visual Description

Structure: Basalt pillow sequence.

Texture: Basalt - primarily microlitic. Pillow margins, have glassy rim, and varioitic interior, Basalt is porphyritic.

Mineralogy: Plagioclase and olivine phyric - $20 \%$ phenocrysts. Plagioclase/olivine
$=2.5 / 1$. Olivine 1 to $2 \mathrm{~mm}$, plagioclase 1 to $5 \mathrm{~mm}$. Plagioclase with abundant dark

Ateration: 1) Basalt altered brown along cracks. 2) Vesicles filled with dark clay.

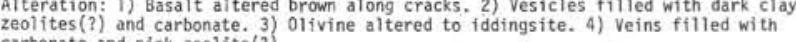

Shipboard Data

mystcal Properties: $36-38$

$\overline{\mathrm{V} p}(\mathrm{~km} / \mathrm{sec})$

Porosity (s) $\quad 4.8$

$\begin{array}{ll}\text { Wet Bulk Density } & 2.68 \\ \text { Grain Density } & 2.76\end{array}$

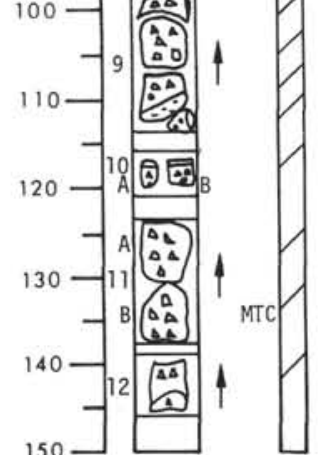

150 

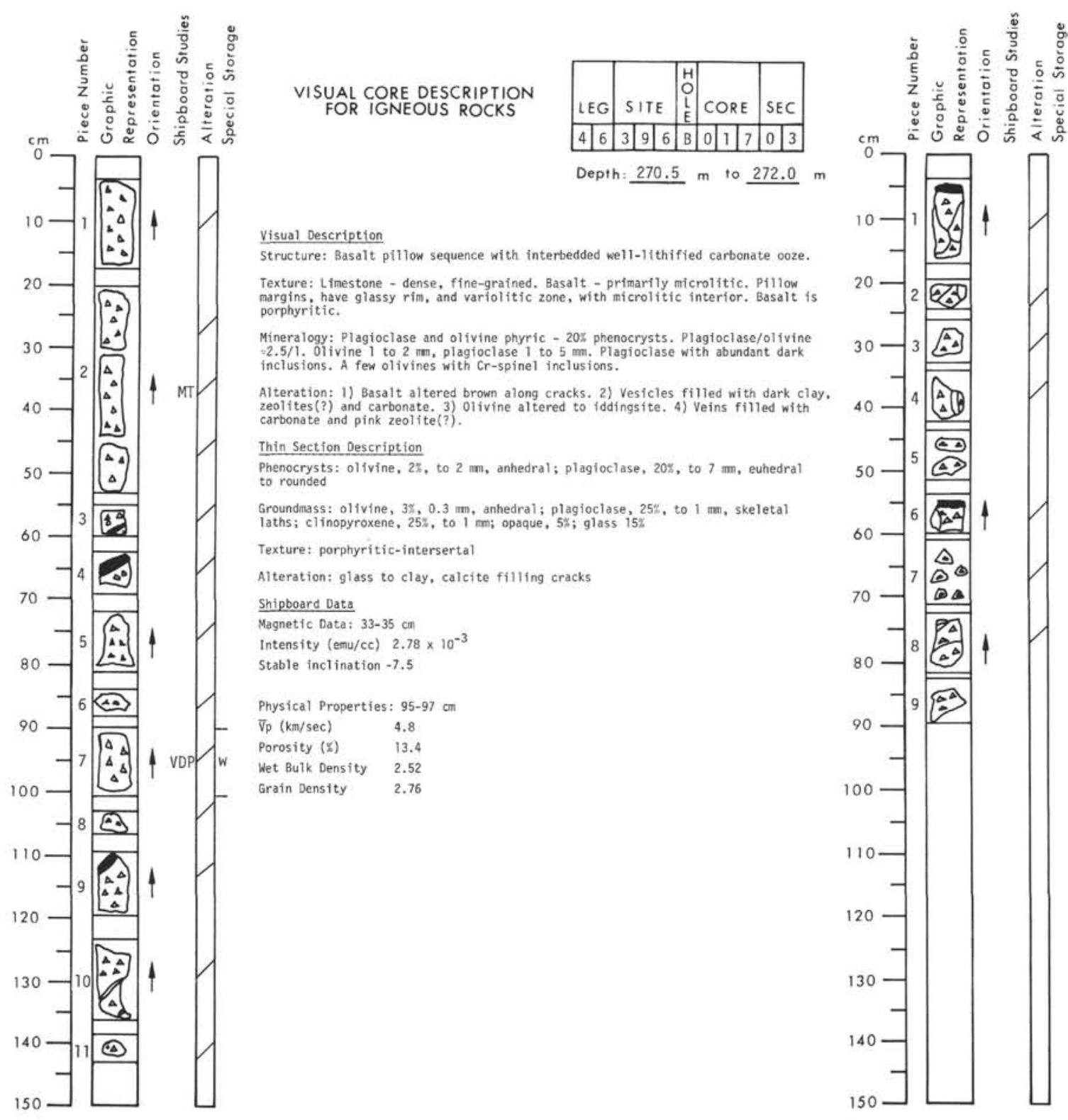

VISUAL CORE DESCRIPTION
FOR IGNEOUS ROCKS

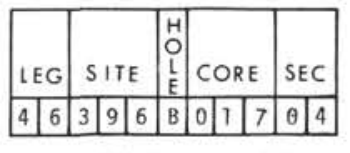

Depth: $272.0 \mathrm{~m}$ to $273.0 \mathrm{~m}$

Visual Description

Structure: Basalt pillow sequence.

Texture: Basalt - primarily microlitic. Pillow margins, have glassy rim, and vario-
litic zone, with microlitic interior. Basalt is prophyritic,

Mineralogy: Plagioclase and olivine phyric -202 phenocrysts. Plagioclase/olivine

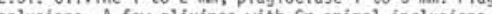

Alteration: 1) Basalt altered brown along cracks. 2) Vesicles filled with dark clay carbonate and pink zeolite(?) 


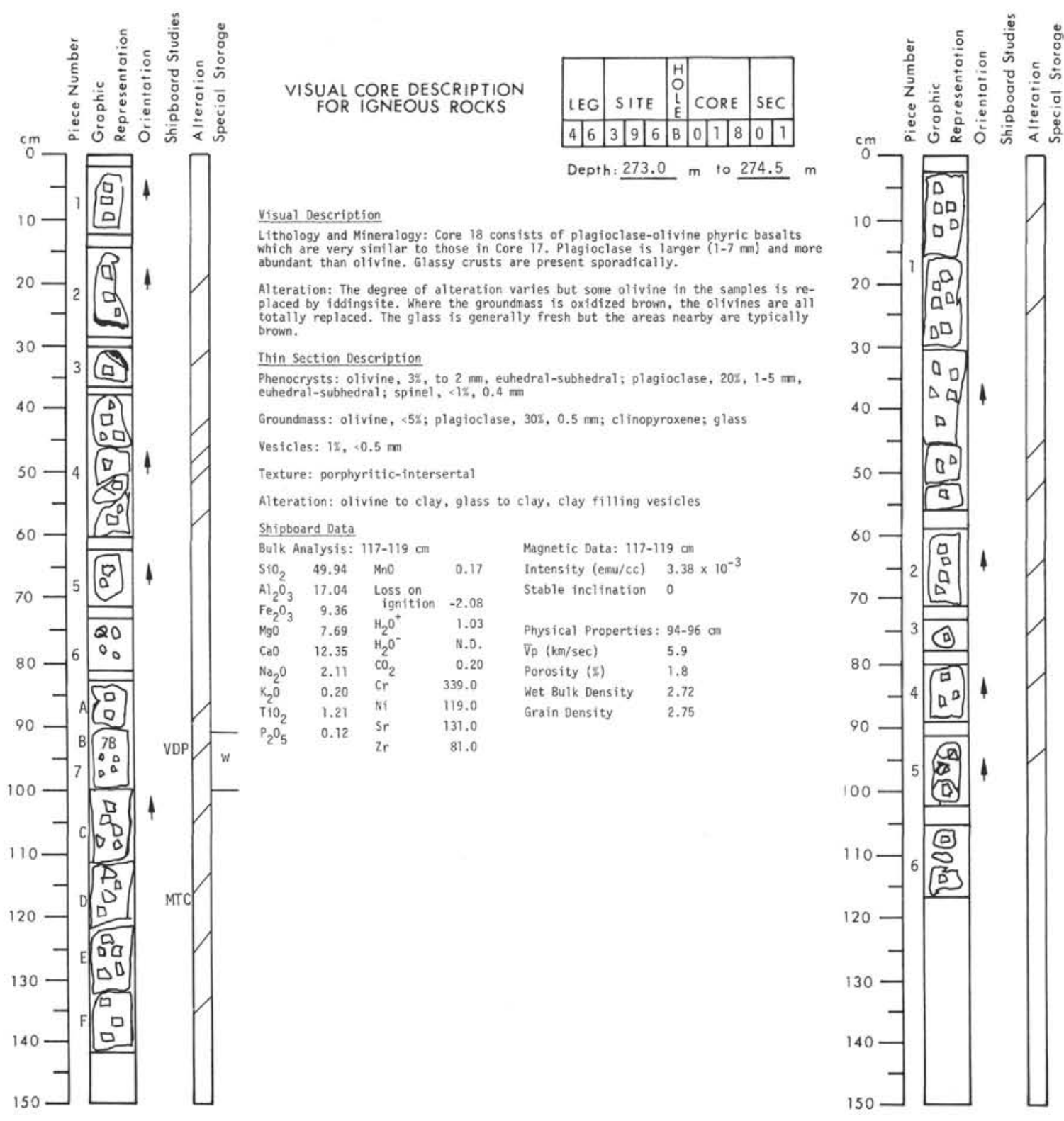
VISUAL CORE DESCRIPTION
FOR IGNEOUS ROCKS

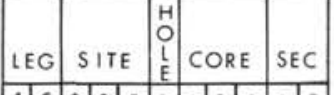

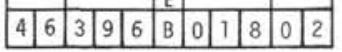

Depth: $274.5 \mathrm{~m}$ to $276.0 \mathrm{~m}$

Visual Description

Lithology and Mineralogy: Core 18 consists of plagfoclase-olivine phyric basalts absuant than olivine. Glassy crusts are present sporadically.

Alteration: The degree of alteration varies but some olivine in the samples is retotally replaced. The glass is generally fresh but the areas nearby are typically

\section{Wisual description}

hin Section Description

12.35

.11

0.20

5.9

$\begin{array}{lll}\mathrm{K}_{2} \mathrm{O} & 0.20\end{array}$

131.0
81.0 


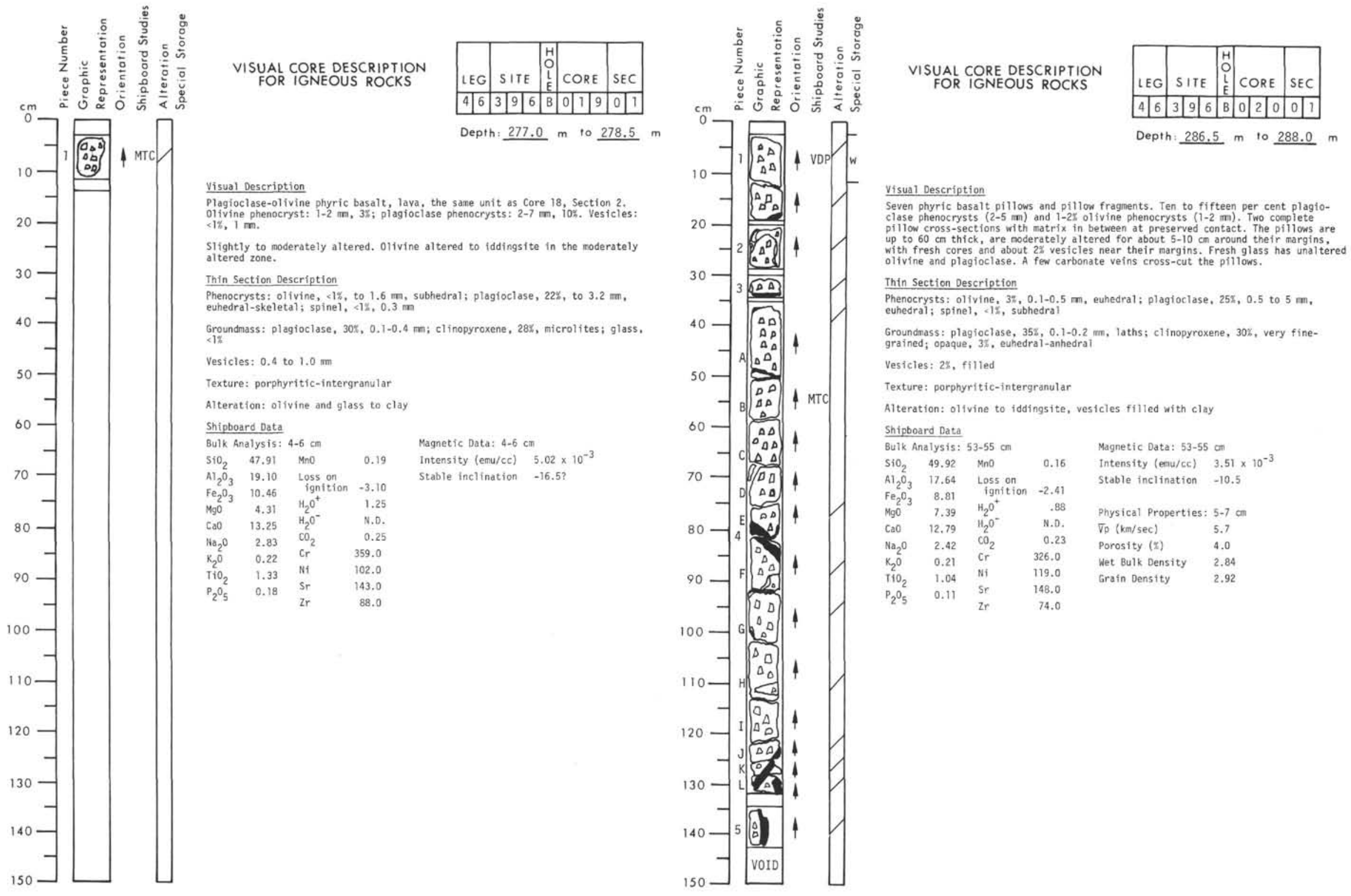




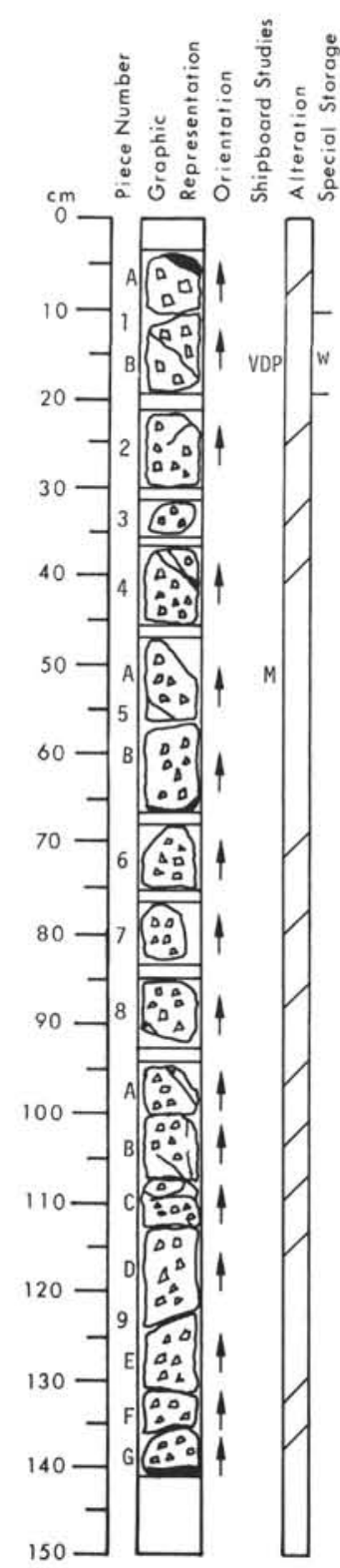
VISUAL CORE DESCRIPTION
FOR IGNEOUS ROCKS

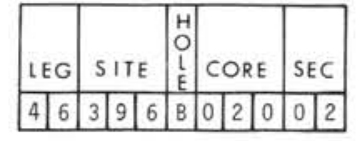

Visual Description

Structure: Mecascopically the same plagioclase-olivine phyric pillow basalt unit as

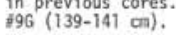

Texture: Glassy to intersertal, porphyritic texture. Vesicles: $0.5 \mathrm{~mm},<0.5 x$.

Mineralogy: 01 ivine phenocryst: 1-2 mm, 2-3r; Plagioclase phenocrysts: $2-4 \mathrm{~mm}$ (max, $10 \mathrm{~mm}), 15-20 \%$.

Aiteration: There are two alteration units except for alteration zone next to glassy

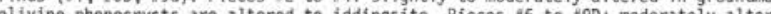
in grouncrass: orivine phenocrysts are altered to iddingsite; abundant calcito

\section{Shipboard Data}

Magnetic Data: $51-53$ on

Intensity (emu/ce) $3.15 \times 10^{-3}$

Stable inclination -0.5

Physical Properties: 14-16 cm

$\nabla p(\mathrm{~km} / \mathrm{sec}) \quad 5.8$

Porosity $(z)$

4.6

Pet Bulk Density

2.82

Grain Density

2.91

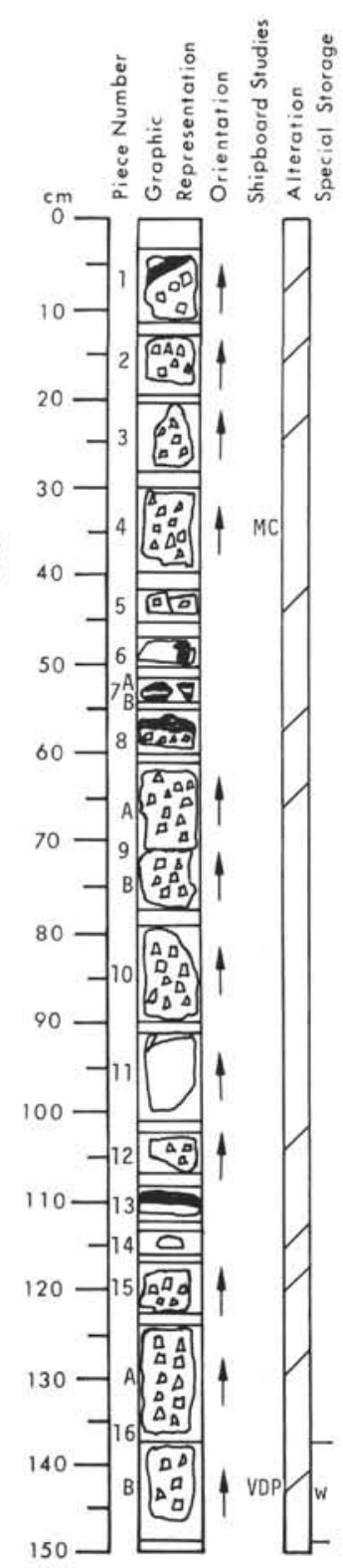

DESCRIPTION FOR IGNEOUS ROCKS

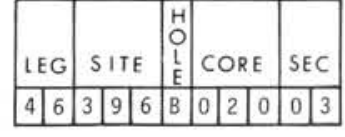

Depth: $289.5 \mathrm{~m}$ to $291.0 \mathrm{~m}$

Visual Description

Structure: pillow lavas alternating with indurated carbonate oozes.

Texture and Mineralogy: From glassy to phyric with 15 to $25 x$ plagioclase phenocrysts (up to $6.5 \mathrm{~mm}$ ) and with 5 to $10 \%$, generally iddingsitized, olvine pheno-
crysts. (up to 4 min) set in a aphanitic matrix. A few small (rarely up to 1 min) round and hollow vesicles.

Alteration: Generally moderately to weakly altered but never really fresh. Few (tissures. Oifvine is generally altered to "iddingsite."

Shipboard Data

Magnetic Data: $33-35 \mathrm{cn}$

$\begin{array}{llllll}\mathrm{SiO}_{2} & 49.28 & \mathrm{MnO} & 0.16 & \text { Intensity (emu/cc) } & 2.67 \times 10^{-3}\end{array}$

$\mathrm{Al}_{2}{ }_{3}{ }_{3} \quad 17.30$ Loss on $\quad$ Stable inclination -5.0

$\mathrm{Fe}_{2} \mathrm{O}_{3} \quad 8.69$ ignition -3.74

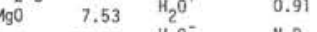

CaO $12.66 \quad \mathrm{H}_{2} \mathrm{O}^{-} \quad$ N.D.

$\mathrm{Na}_{2} \mathrm{O} \quad 2.42 \quad \mathrm{CO}_{2}$

$\begin{array}{llll}\mathrm{k}_{2} \mathrm{O} & 0.21 & \mathrm{Cr} & 347.0\end{array}$

$\mathrm{THO}_{2} \quad 1.10 \mathrm{Ni}-139.0$

Physical Properties: $142-144 \mathrm{~cm}$

$\overline{V_{p}}(\mathrm{~km} / \mathrm{sec})$

5.5

Wet Bulk Density 2.80

$\begin{array}{llll}\mathrm{P}_{2} \mathrm{O}_{5} & 0.10 & \mathrm{Sr} & \mathrm{7m} \\ \mathrm{Zr} & & 66.0\end{array}$ 


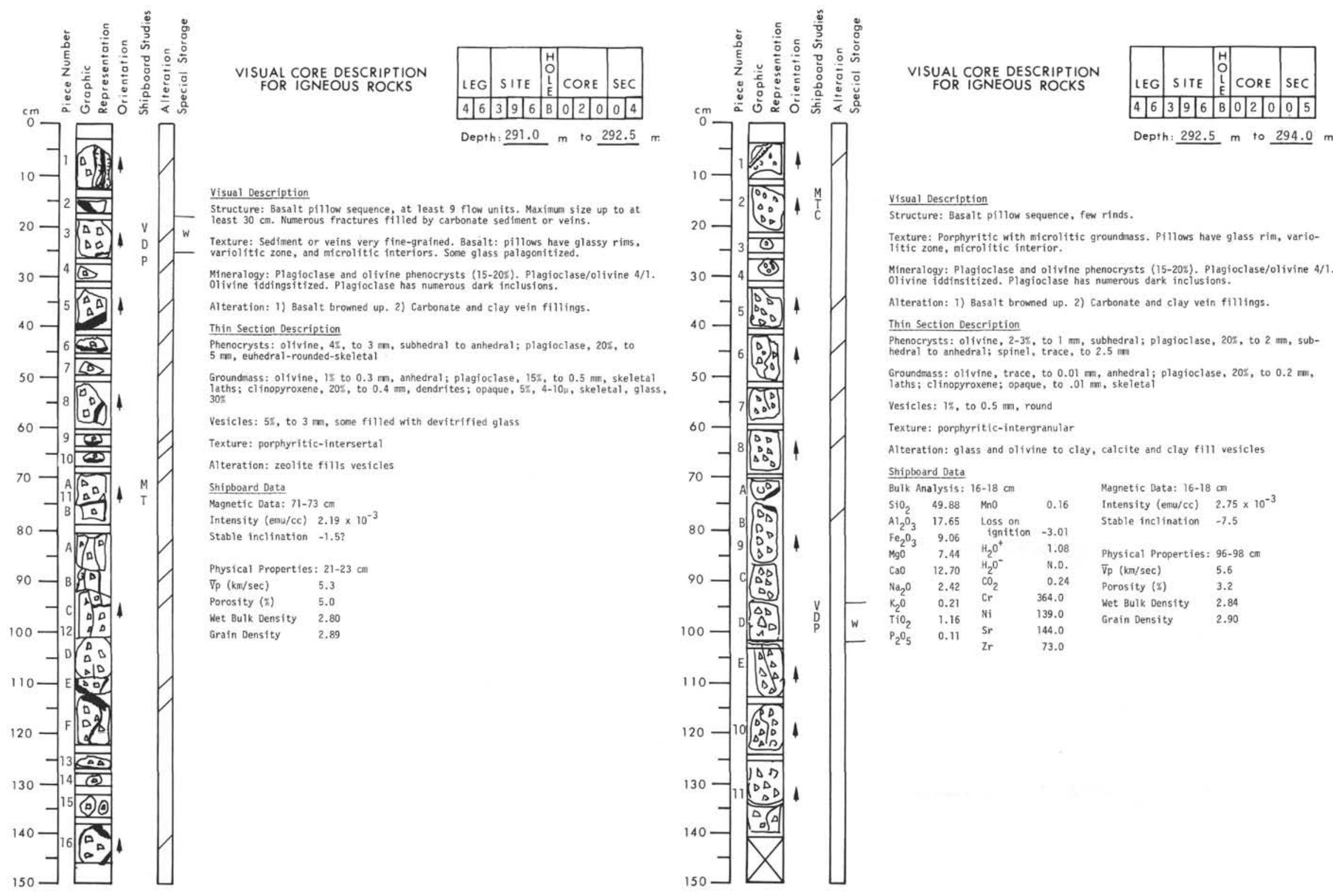



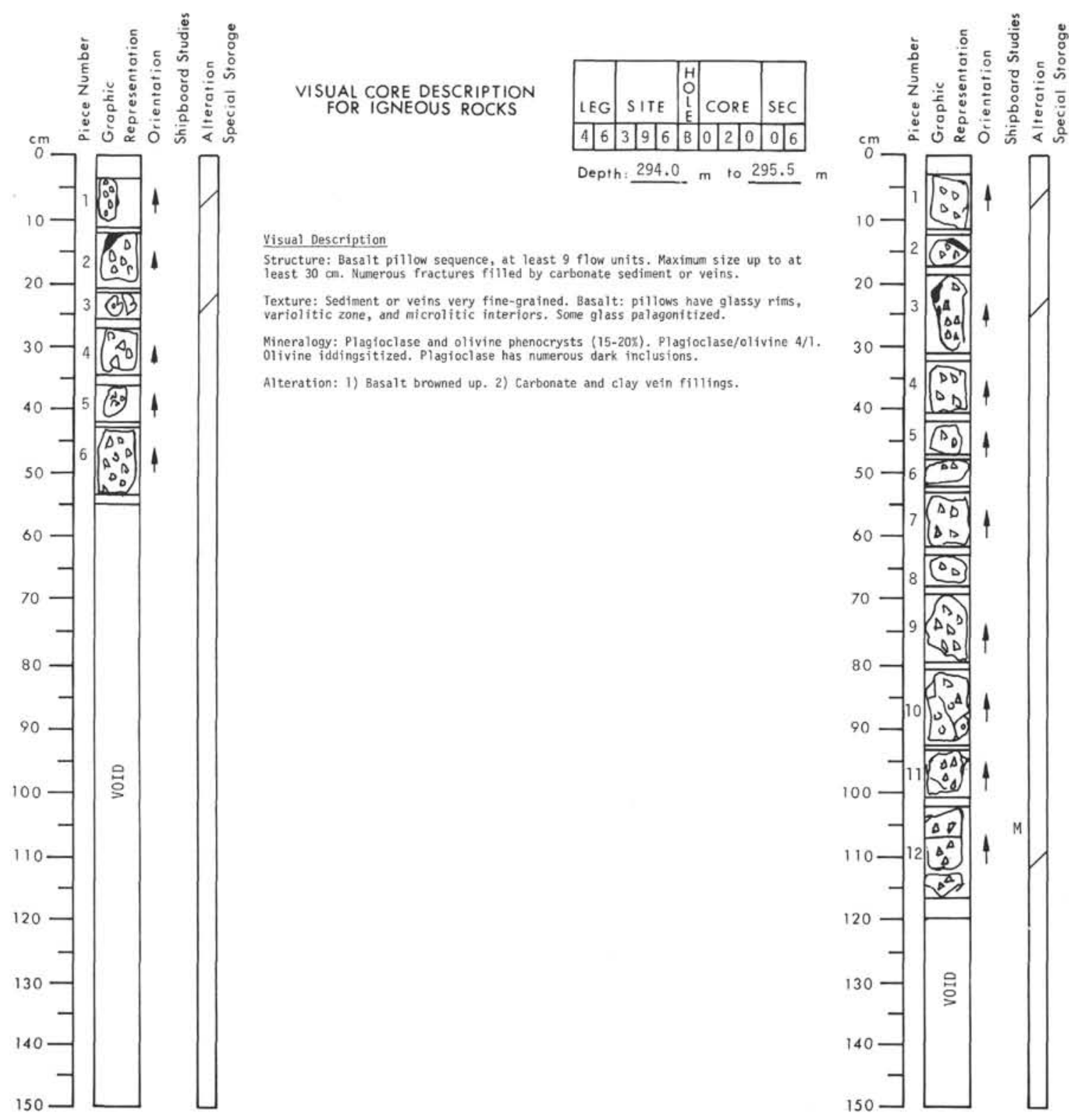

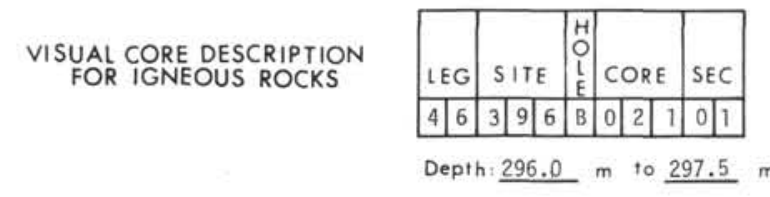

Visual Description

Structure: Basalt pillow sequence. Some fracturing.

Texture: Primarily microlitic. Pillow margins have glass, variolitic zone, and

Mineralogy: Plagioclase and olivine phyric $=20 x$ total phenocrysts. Plagioclasel inclusions.

Alteration: Plagioclase altered blue-green, 01ívine iddingsitized. Basalt altered brown. Carbonate, clay(?), and zeoil ite veins.

Shipboard Dat:

Intensity (emu/cc)

$2.61 \times 10^{-3}$

Stable inclination

$-8.5$

Texture: Sediment or veins very fine-gra ined. Basalt: pillows have
variolitic zone, and microliticic interiors. Some glass palagonitized.

01 ivine iddingsitized. Plagioclase has nurerous dark inciusions.

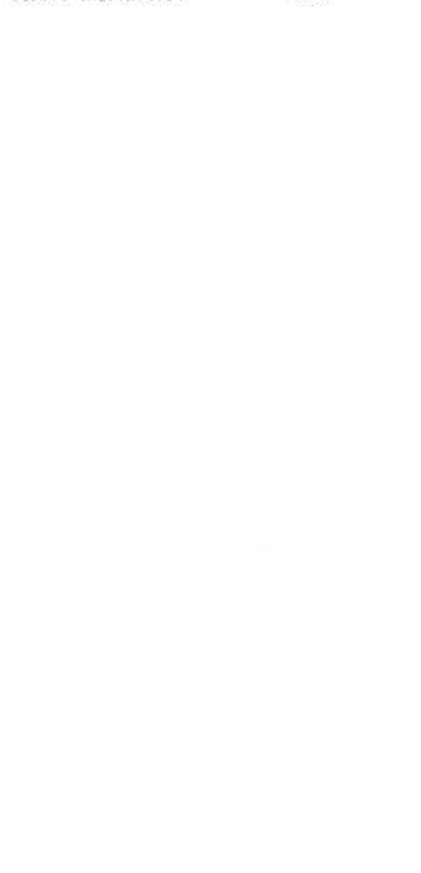




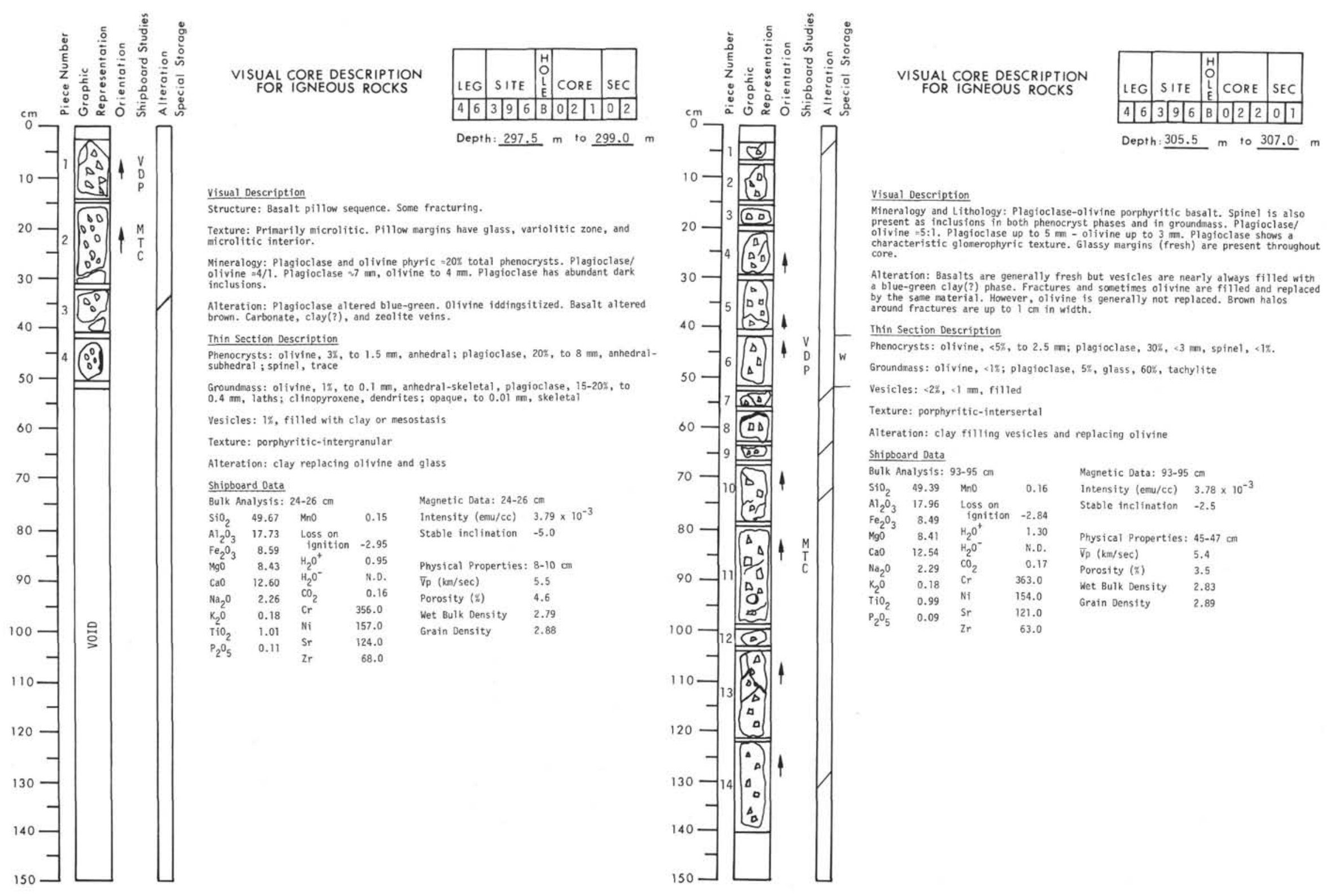




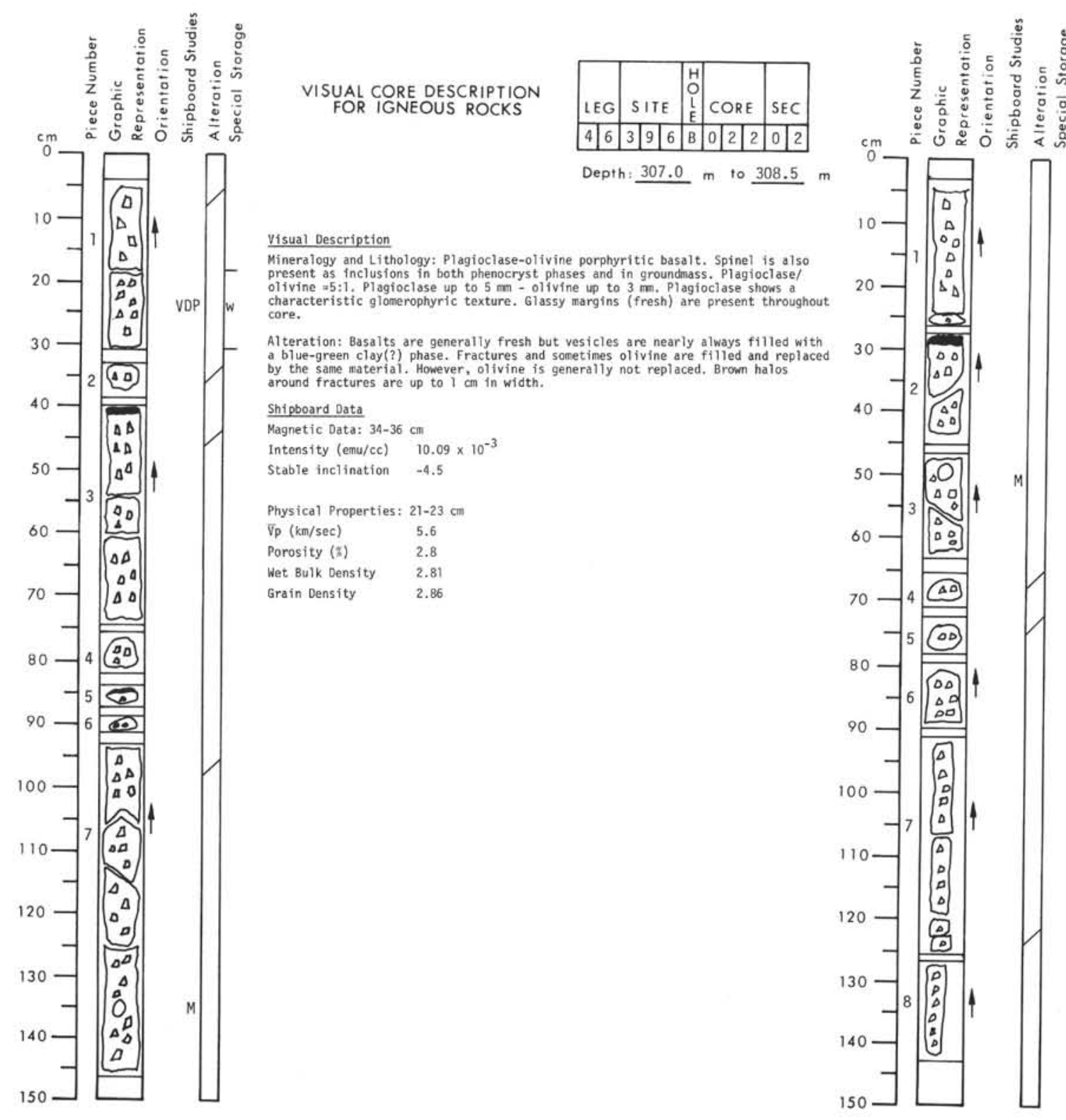

\section{VISUAL CORE DESCRIPTION
FOR IGNEOUS ROCKS}

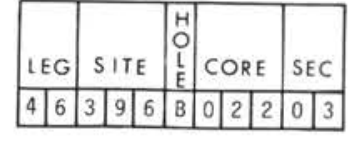

Depth: $308.5 \mathrm{~m}$ to $\underline{310.0 \mathrm{~m}}$

Visual Description Mineralogy and Lithology: Plagioclase-olivine porphyritic basalt. Spinel is also
present as inclusions in both phenocryst phases and in groundmass. Plagioclase/ olivine $=5:$ : Plagioclase up to $5 \mathrm{~mm}$ - olivine up to 3 mo. Plagioclase shows a
characteristic glomerophyric texture, Glassy margins (fresh) are present throughout
core, core.

Alteration: Basalts are generally fresh but vesicles are nearly always filled with a blue-green clay( (?) phase. Fractures and sometimes olivine are filled and replaced by the same naterial. However, olivine is generally not replaced, Brown hal os
around fractures are Shipboard Data

Magnetic Data: $50-52 \mathrm{~cm}$

intensity (emu/cc) $3.16 \times 10^{-3}$

table inclination $-5,0$ 

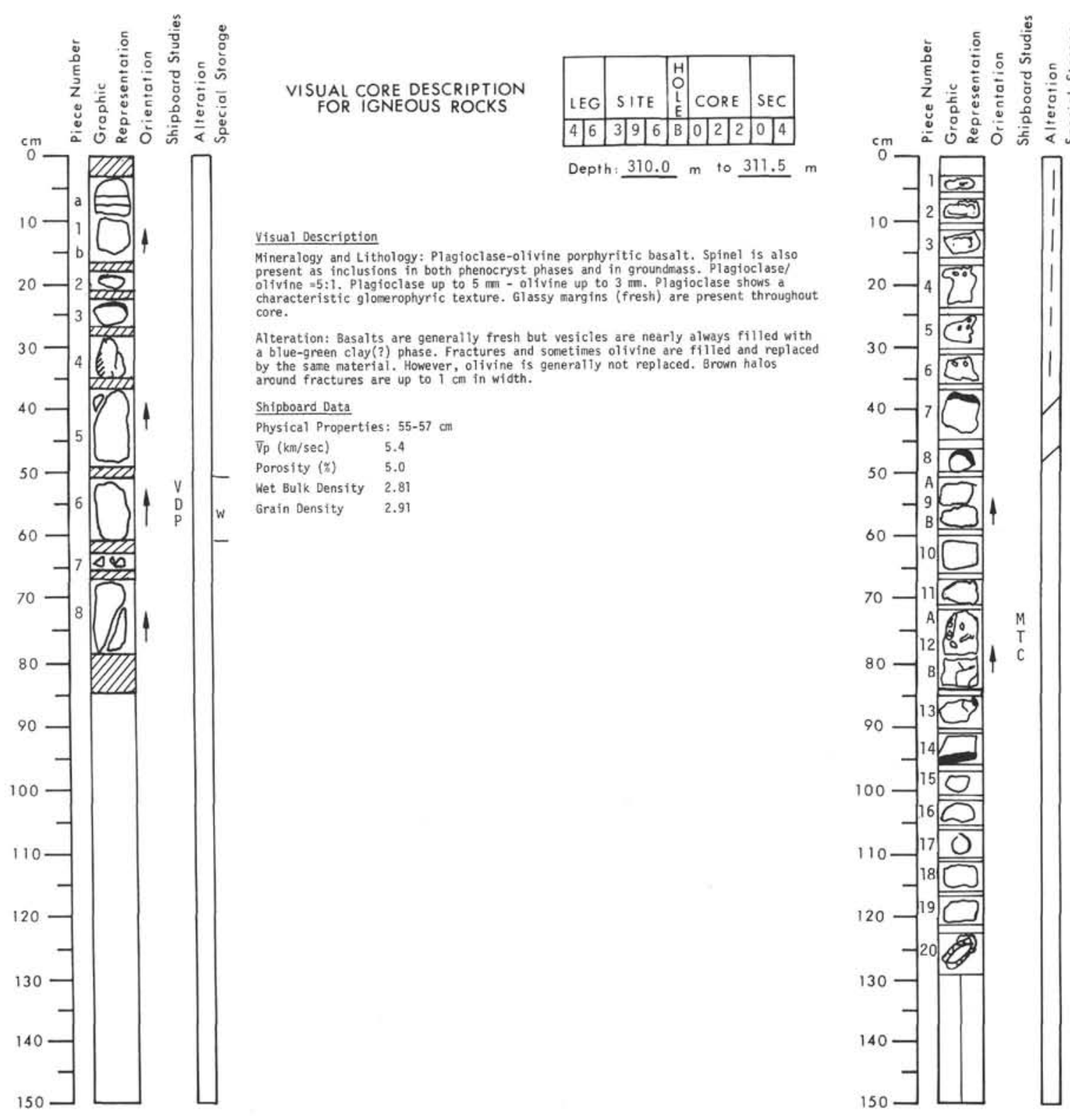
VISUAL CORE DESCRIPTION
FOR IGNEOUS ROCKS

\begin{tabular}{|c|c|c|c|c|}
\hline EG & SITE & $\mathrm{H}$ & CORE & SEC \\
\hline \begin{tabular}{l|l}
4 & 6
\end{tabular} & \begin{tabular}{|l|l|l}
3 & 9 & 6 \\
\end{tabular} & & \begin{tabular}{l|l|l}
0 & 2 & 3
\end{tabular} & \begin{tabular}{|l|l|}
0 & 1 \\
\end{tabular} \\
\hline
\end{tabular}

Depth: 315.0 m to 316.5

Visual Description

thology: A) $0-50 \mathrm{~cm}$ rather irregular vesicular basalt fragnents. B) 50-78 cm partily palagonitized sideromelane pillow-rind breccia cemented by zeolites. $\mathrm{C}$ )
$78-127$ com more massive, fine-grained basalt (some pillow margins) some with breccia
adhering.

Minera logy: In strong contrast to previous units, basalt is only sparsely phyric
(<15) with olivine more abundant than plagioclase, both generally $\& 1 \mathrm{lmm}$.

probably :

crust and globules as lining of cavities, abundant zeolites, carbonate, some clay,

silica? The most unusual rock ts the palagonitized sideromel ane breccia, the upper

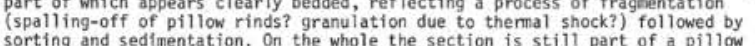
basalt sequence.

Thin Section Description

Phenocrysts: 01ivine, <1\%, $0.2 \mathrm{~mm}$, euhedral; plagioclase; $<1 \%, 1 \mathrm{~mm}$, rounded

Groundmass: olivine, $\times 5 \%$; plagioclase, 30\%, microlites; glass

Vesilces: <5\%, mostly unfilled

Texture: intersertal

Alteration: clay, calcite, and zeolite fill vesicles, glass to clay and Fe-

Shipboard Data

Bulk Analysis: $87-89 \mathrm{~cm} \quad$ Magnetic Data: $80-82 \mathrm{~cm}$

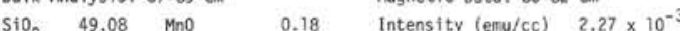

$\mathrm{Al}_{2} \mathrm{O}_{3} 16.01$ Loss on Stable inclination +54.0

$\mathrm{Fe}_{2} \mathrm{O}_{3} \quad 10.58$ ignition -1.50

$\begin{array}{llll}\mathrm{MgO}^{2} & 7.37 & \mathrm{H}_{2} \mathrm{O}^{+} & 0.76\end{array}$

CaO $\quad 11.74 \quad \mathrm{H}_{2} \mathrm{O}^{-} \quad$ N.D,

$\begin{array}{llll}\mathrm{Na}_{2} \mathrm{O} & 2.59 & \mathrm{CO}_{2} & 0.17\end{array}$

$\begin{array}{llll}\mathrm{K}_{2} \mathrm{O} & 0.35 & \mathrm{Cr} & 346.0\end{array}$

$\mathrm{PHO}_{2} \quad 1.58 \quad \mathrm{Ni} \quad 140.0$

$\begin{array}{llll}\mathrm{P}_{2} \mathrm{O}_{5} & 0.17 & \mathrm{Sr} & 163.0 \\ & & \mathrm{Zr} & 106.0\end{array}$ 


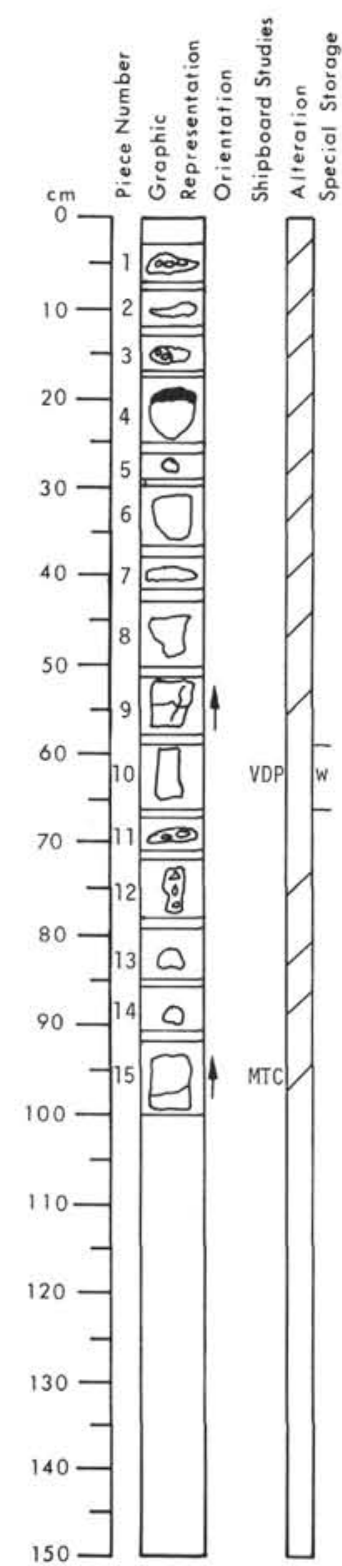
VISUAL CORE DESCRIPTION
FOR IGNEOUS ROCKS

Core 24 is similar in 1ithology to Core 23: fine-gratined basalt, pillow rind fragglassy basait.

Yesicles partly filled by carbonate - but generally open (1) except for bluish clay
lining, fener breccias and pillow rinds than in core 23 ,

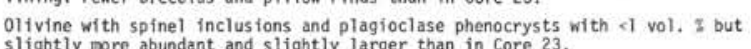

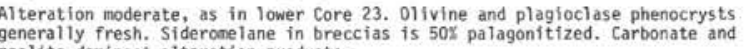

Thin Section Description

Phenocrysts: 01ivine, <1\%, <2 mm; plagioclase, <1\%, <1.5 mn, rounded

Groundrass: olivine, <2\%, plagioclase, 20-30\%, glass, 70\%, tachylite

Vesicles: $1 \%$, some filled by glass

Texture: intersertal

Shipboard Data

Bulk Analysis: 94-96 cm Magnetic Data: $94-96 \mathrm{~cm}$

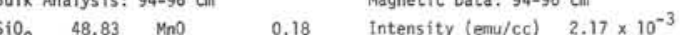

$\mathrm{Al}_{2} 0_{3} \quad 16.06$ Loss on $\quad$ Stable inclination +16.0

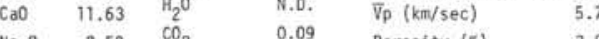

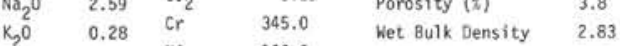

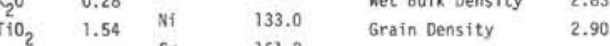

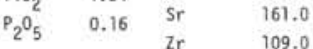

109.0
$\mathrm{Fe}_{2} \mathrm{O}_{3}$ 10.45 ignition -1.87

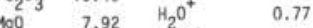

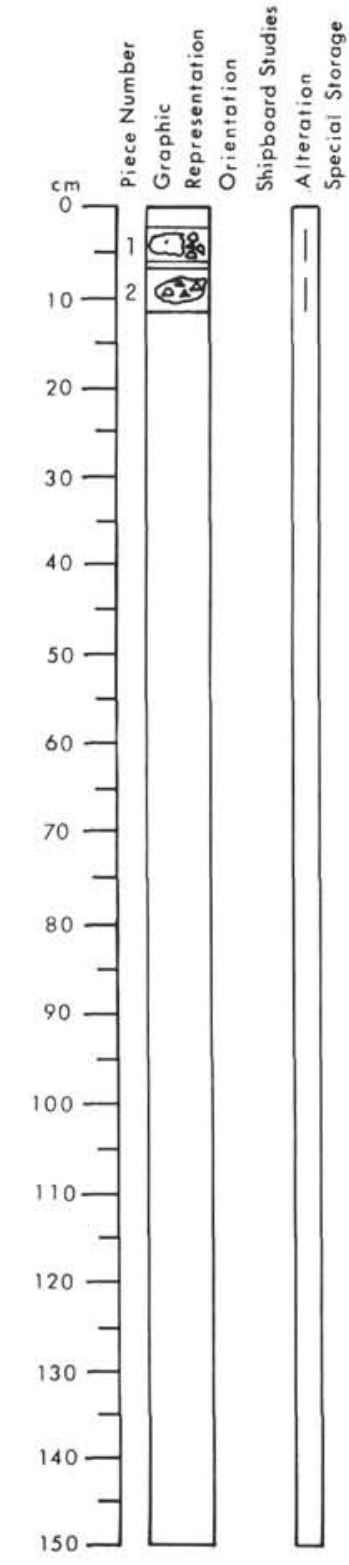

\section{VISUAL CORE DESCRIPIION}

150
Visual Description

Partly palagonitized sideromelane (fresh, dense) breccia cenented by zeolite
crusts. As in Core 24, some angular pore crystallizized basalt piecess somet times but not always representing pillow rinds. Thus, there must have been unusually fewer and smaller phenocrysts than in Core 24. Low recovery in cores 23-25 may be due to abundance of breccias and/or bad weather. 

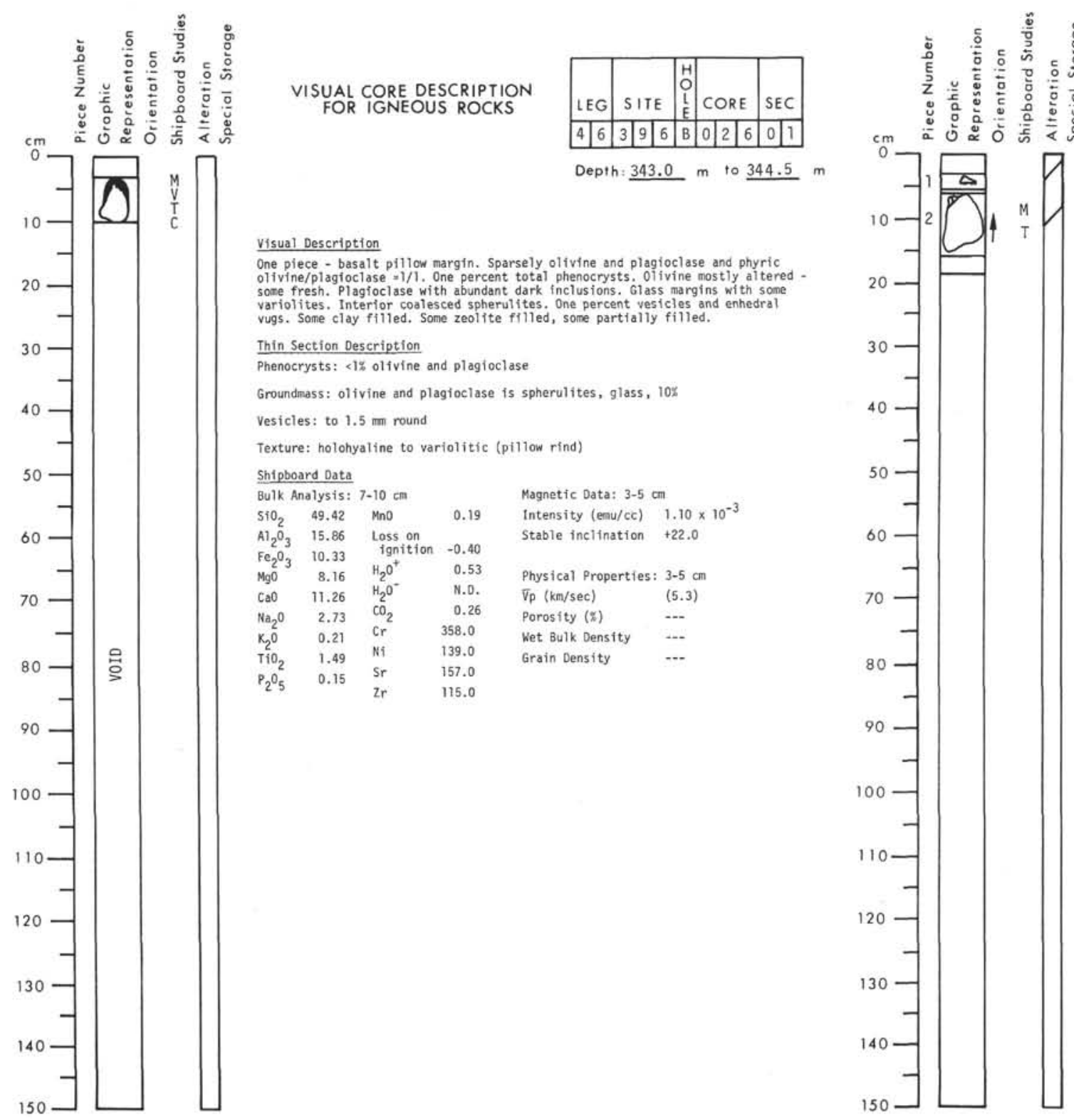

\section{VISUAL CORE DESCRIPTION
FOR IGNEOUS ROCKS}

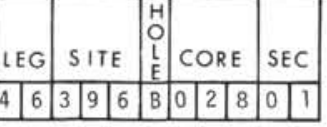

Depth: $\underline{358.0} \mathrm{~m}$ to $\underline{359.5} \mathrm{~m}$

Visual Description

Structure: One weathered basalt fragnent and one small chip or variolitic pillow
rind.

Mineralogy: 01ivine and plagioclase sparsely phyric basalt. A few olivine phenoshapes. Glass fragment contains a few olivine and plagioclasephenocrysts, 1-0.5 m and 7 mit respectively totaling less than $3 x$.

Alteration: Basalt fragnent has a weathered appearance, is brownish green-gray in mineral (alis trequent vesicles a tised with the glass between the varioles appears quite fresh, while the varioles are altered to palagonite at the surface.

Thin Section Description

Phenocrysts: olivine, $3 \%, 0.2-1.5 \mathrm{~mm}$, euhedral; plagioclase, $5 \%, 0.2-2 \mathrm{~mm}$, subhedral; spinel, <1\%, 40, subhedral Groundass: plag1oclase, 50\%, variolitic; clinopyroxene, 20-30\%, granules and
microlites; opsque, 6\%, 10-50: anhedral-dendritic Vesicles: filled

Texture: porphyritic-intergranular

Alteration: olivine to iddingsite, groundmass to clay, calcite filling vesicles Shipboard Data

Magnetic Data: $10-12 \mathrm{~cm}$

Intensity (enu/cc) $2.46 \times 10^{-3}$

stable inclination $-6.5 ?$ 


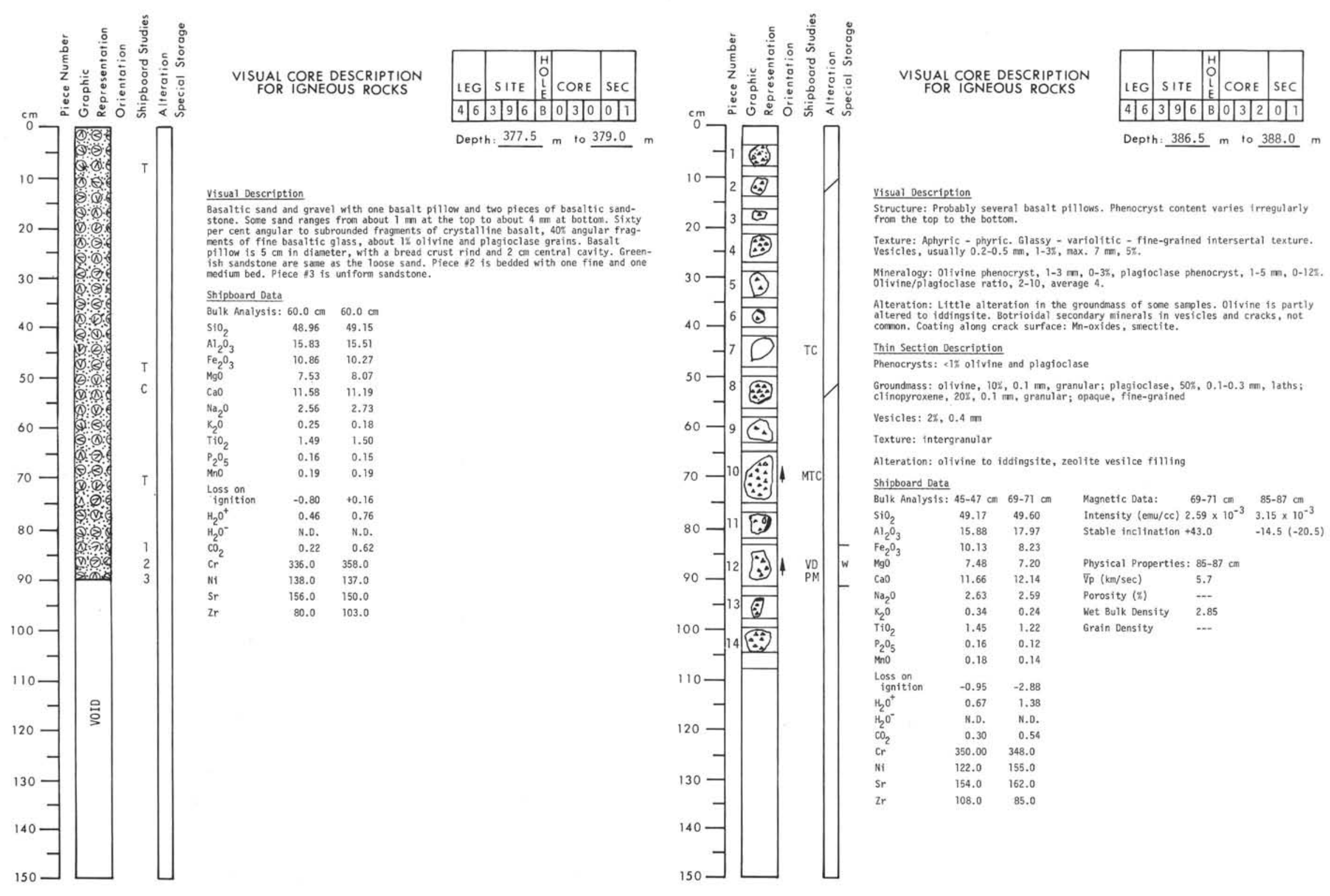




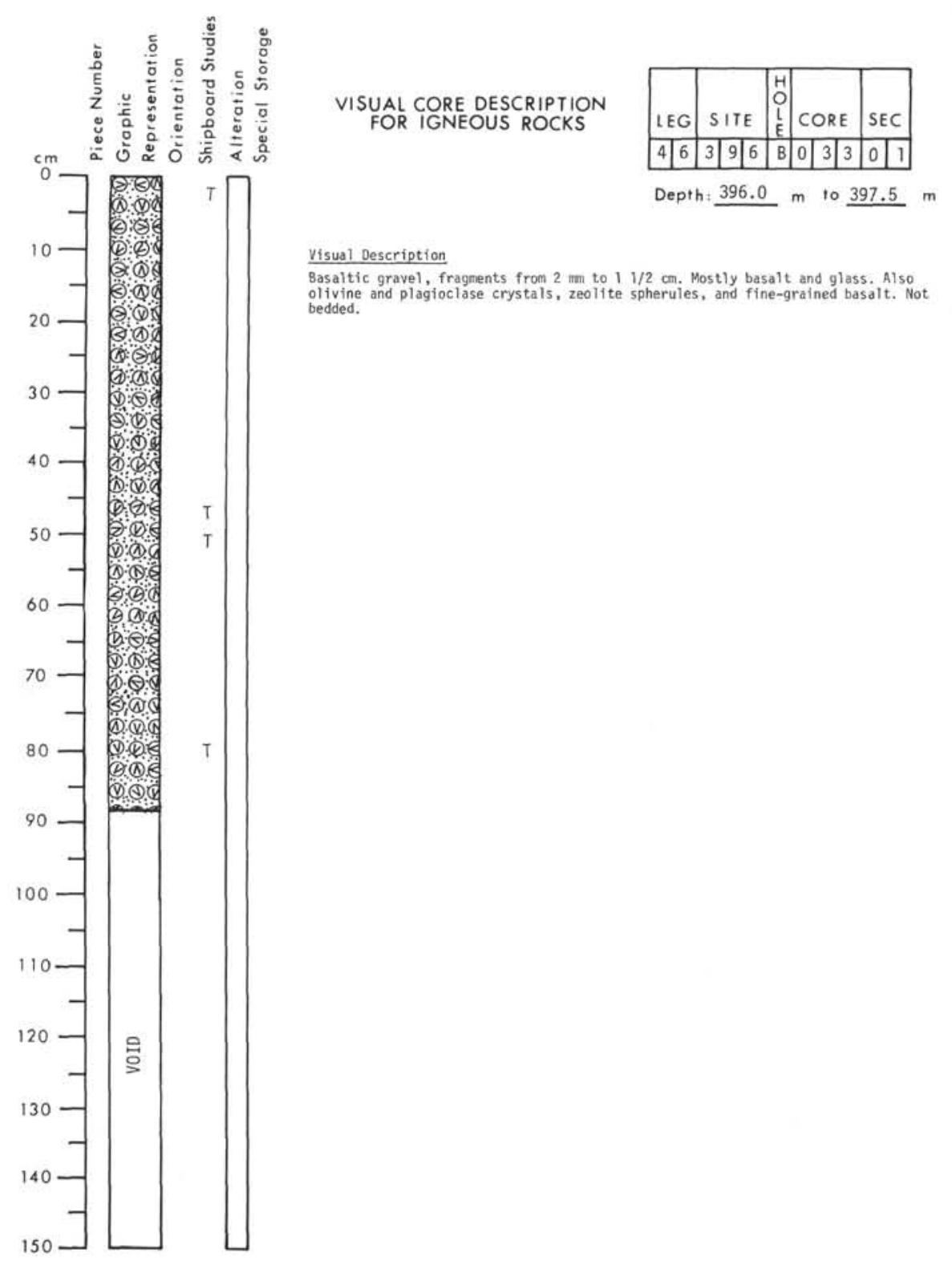


Site 396B

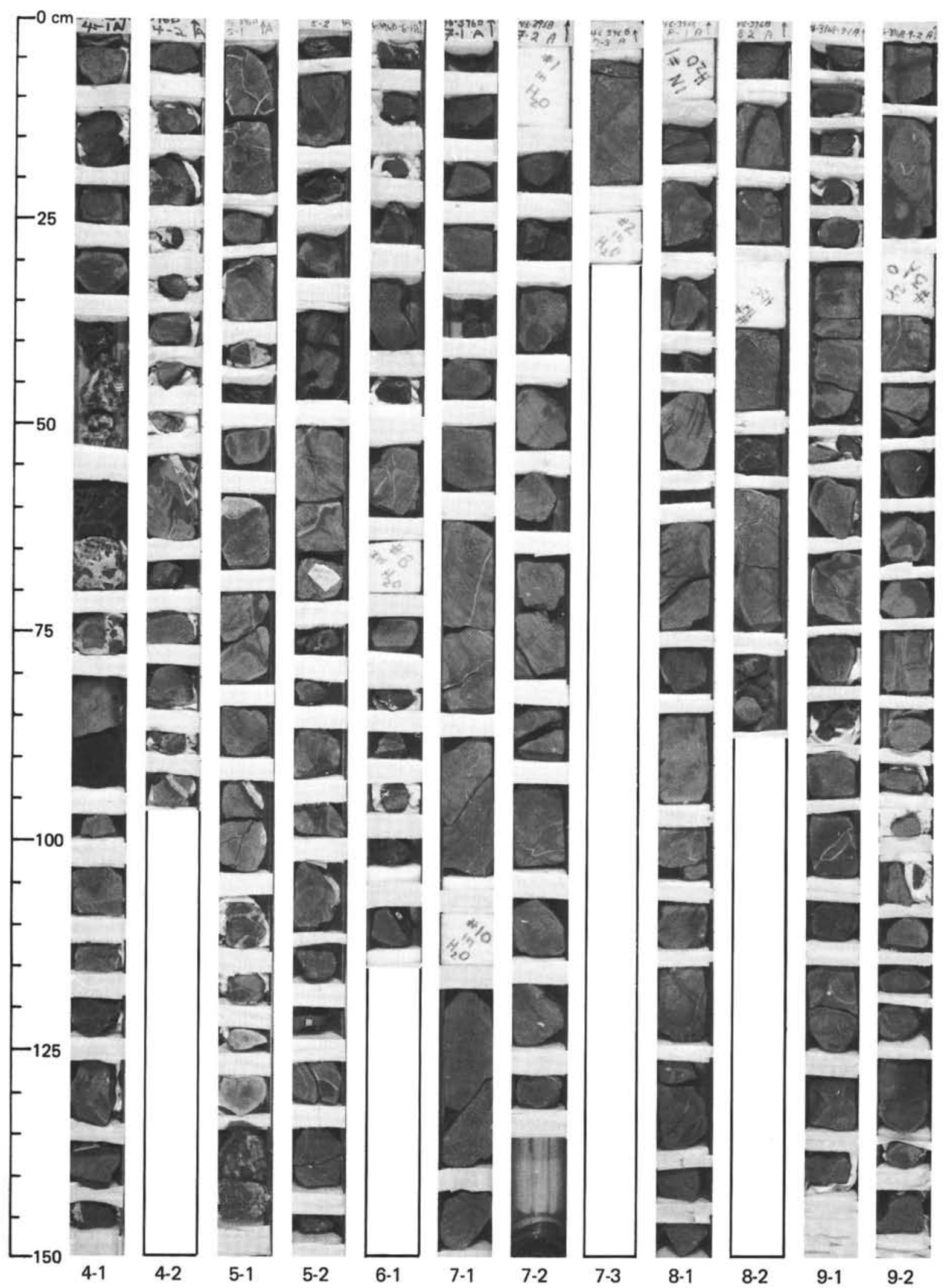


Site 396B

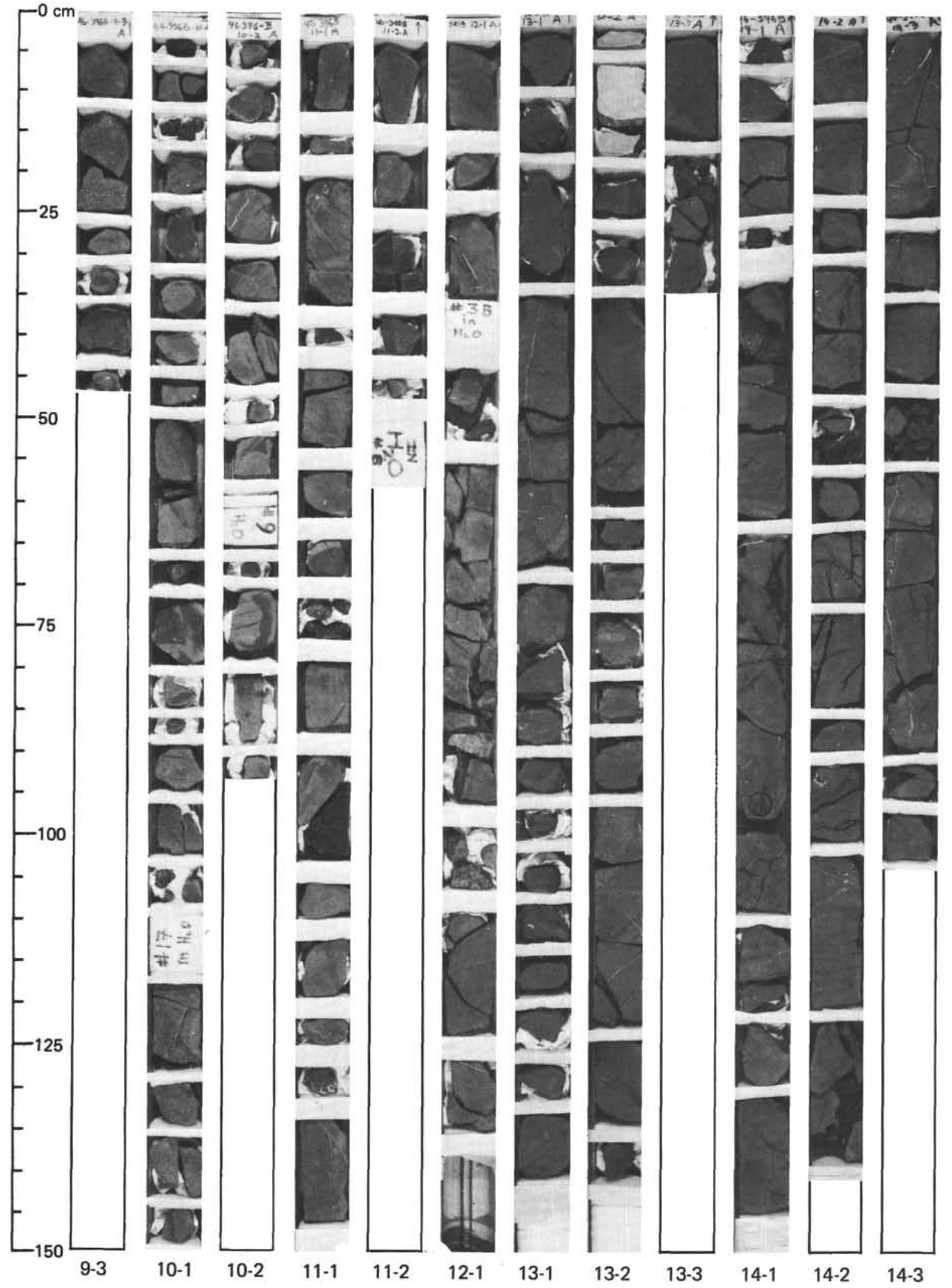


Site 396B

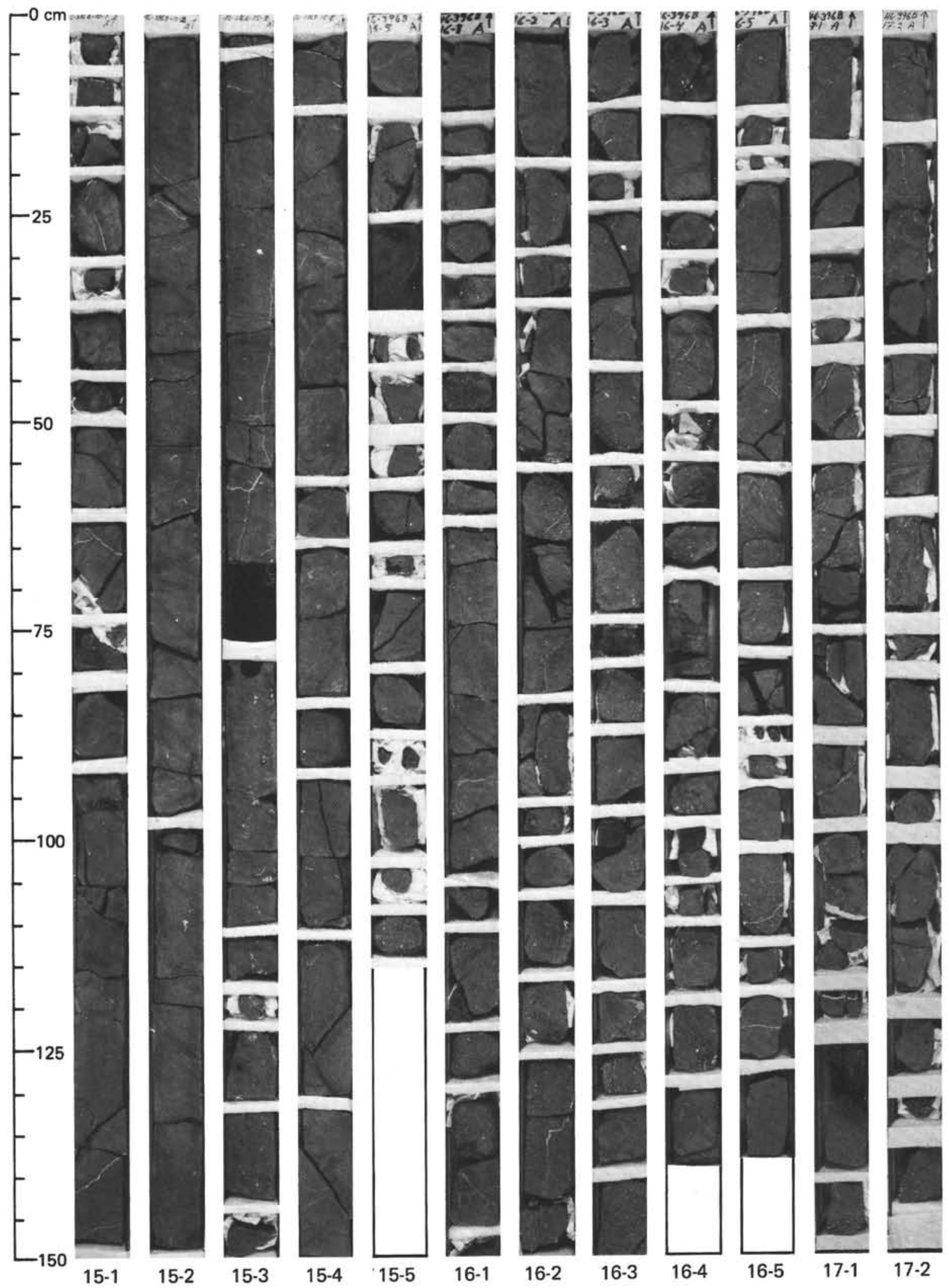


Site 396B

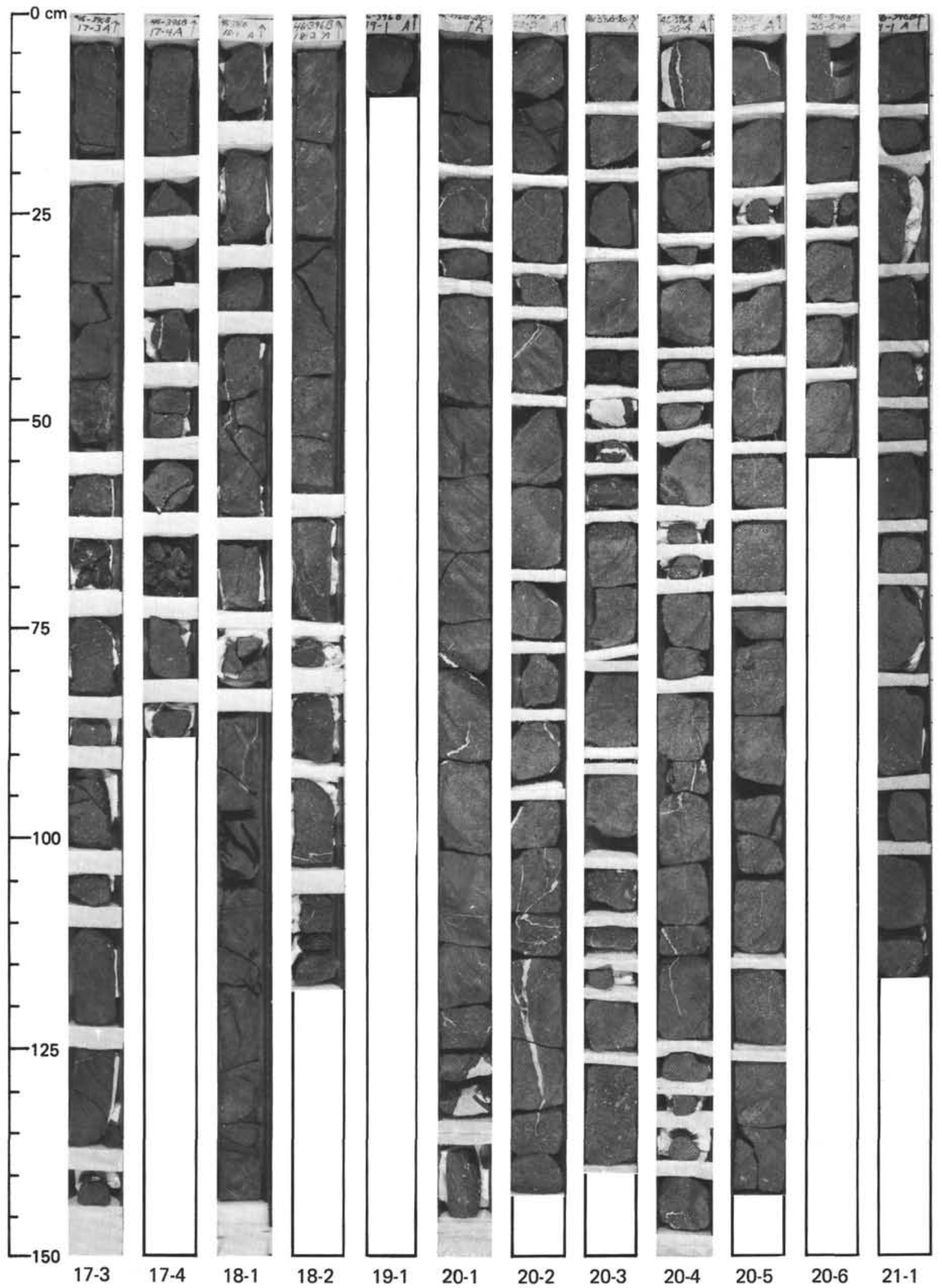


Site 396B

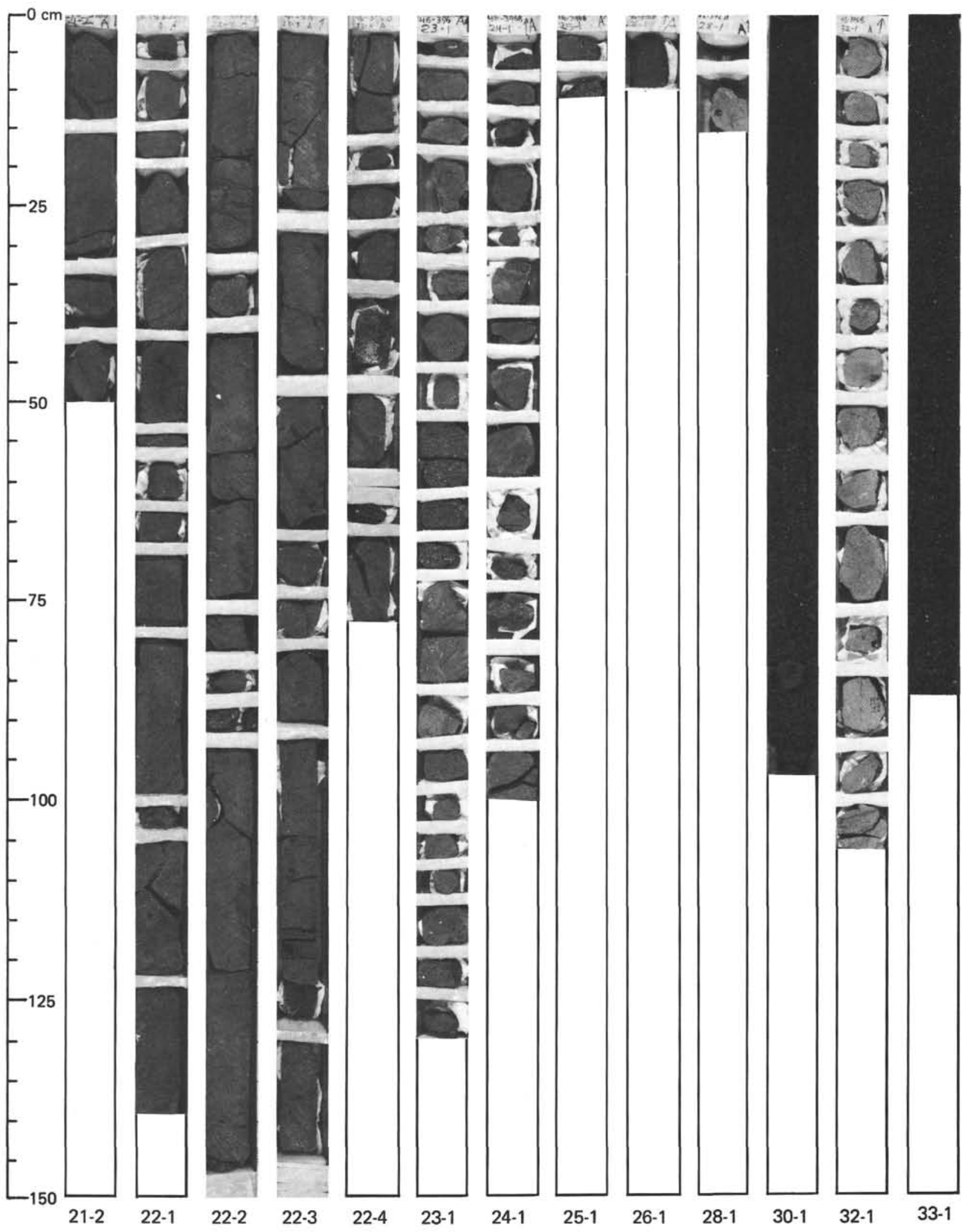

